\title{
Institutional Change in Japan
}

\begin{abstract}
After four decades of rapid growth that transformed Japan into a wealthy country at the world's technological frontier, the decade of the 1990s brought prolonged economic stagnation. The rapid run-up in asset prices in the late 1980s, followed by their collapse in the early 1990s, left a debt overhang that paralyzed the economy. Policy reforms were initially halfhearted, and businesses were slow to restructure as the global economy changed. Indeed, Japan's struggle has called into question the ability of the country's economic institutions - originally designed to support factor accumulation and rapid development - to adapt to the new economic environment of the twenty-first century.

Institutional Change in Japan analyzes institutional change within this period of economic transition. It addresses the origin, development, and recent adaptation of core institutions, including financial institutions, corporate governance, lifetime employment, the amakudari system and marriage and family. Importantly this analysis is grounded in a broad historical and international context, with comparisons made to Meiji Japan as well as to recent economic and financial reforms in Korea, Switzerland and New Zealand.

A leading field of international contributors contend that, contrary to conventional wisdom, there has been significant institutional change over the last decade. Institutional Change in Japan consequently offers a fresh perspective to the current debate that will be essential reading for those studying the Japanese economy, economic history/futures and institutional economics.
\end{abstract}

Magnus Blomström is Professor of Economics at the Stockholm School of Economics and President of the European Institute of Japanese Studies. Sumner La Croix is Professor of Economics at the University of HawaiiManoa. 


\section{European Institute of Japanese Studies, East Asian economics and business series \\ Edited by Marie Söderberg, \\ Stockholm School of Economics, Sweden}

This series presents cutting edge research on recent developments in business and economics in East Asia. National, regional and international perspectives are employed to examine this dynamic and fast-moving area.

1 The Business of Japanese Foreign Aid

Five case studies from Asia

Edited by Marie Söderberg

2 Chinese Legal Reform

The case of foreign investment law

Yan Wang

3 Chinese-Japanese Relations in the Twenty-First Century

Complementarity and conflict

Edited by Marie Söderberg

4 Competition Law Reform in Britain and Japan

Comparative analysis of policy network

Kenji Suzuki

5 Financial Liberalization and the Economic Crisis in Asia

Edited by Chung H. Lee

6 Institutional Change in Southeast Asia

Edited by Fredrik Sjöholm and José Tongzon

7 Japan's China Policy

A relational power analysis

Linus Hagström

8 Institutional Change in Japan

Edited by Magnus Blomström and Sumner La Croix 


\section{Institutional Change in Japan}

\section{Edited by Magnus Blomström and Sumner La Croix}

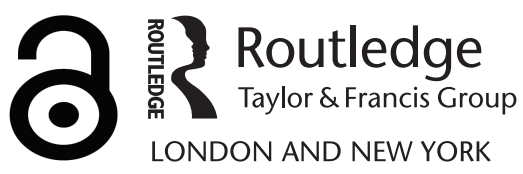


First published 2006

by Routledge

Published 2017 by Routledge

2 Park Square, Milton Park, Abingdon, Oxon OX14 4RN

711 Third Avenue, New York, NY 10017, USA

Routledge is an imprint of the Taylor \& Francis Group, an informa business

Copyright (C) 2006 Editorial matter and selection, Magnus Blomström and Sumner La Croix; individual chapters, the contributors

Typeset in Times by Wearset Ltd, Boldon, Tyne and Wear

The Open Access version of this book, available at www.tandfebooks.com, has been made available under a Creative Commons Attribution-Non Commercial-No Derivatives 4.0 license.

British Library Cataloguing in Publication Data

A catalogue record for this book is available from the British Library

Library of Congress Cataloging in Publication Data

A catalog record for this book has been requested

ISBN13: 978-0-415-38015-7 (hbk) 


\section{Contents}

List of figures vii

List of tables viii

List of contributors ix

Series editor's preface $\quad \mathrm{x}$

Preface xi

Introduction 1

MAGNUS BLOMSTRÖM AND SUMNER LA CROIX

\section{PART I}

Institutional change in theory and practice

1 Institutional change in Japan: theories, evidence and reflections

SUMNER LA CROIX AND AKIHIKO KAWAURA

2 Institutional change in Meiji Japan: image and reality 45

JANET HUNTER

3 Institutional reform in Japan and Korea: why the difference?

CHUNG H. LEE

PART II

Japanese institutions: what has changed, what has not, and why

4 A lost decade for Japanese corporate governance reform? What has changed, what hasn't, and why 
vi Contents

5 Japan's economic and financial stagnation in the 1990s and reluctance to change

THOMAS F. CARGILL

6 Japanese lifetime employment: a century's perspective

CHIAKI MORIGUCHI AND HIROSHI ONO

7 The Japanese labor movement and institutional reform

LONNY E. CARLILE

8 The changing pattern of Amakudari appointments: the case of regional banks, 1991-2000

KENJI SUZUKI

9 Divorce in Japan: why it happens, why it doesn't HIROSHI ONO 


\section{Figures}

4.1 Number of deals involving Japanese targets, 1993-2000 105

4.2 Ratio of bust-up value to market capitalization, 2000 108

5.1 Percentage changes in real GDP 121

5.2 GDP deflator, percentage changes 121

5.3 Percentage changes in the CPI 122

6.1 Separation rates of manufacturing workers, 1923-2001 153

6.2 Union membership, density, and working days lost, 1921-2001 157

8.1 Number of agreements registered by National Personnel Authority for amakudari, 1985-2001 203

9.1 Types of marriages in Japan 227

9.2 Women's labor force participation rates in selected
countries 


\section{Tables}

4.1 Major Commercial Code amendments 1993-2002 98

6.1 Corporate welfare programs in $1949 \quad 160$

6.2 Employment adjustments during business downturns in 1

6.3 Methods of employment adjustment in $2000 \quad 168$

6.4 Top five reasons why workers didn't change jobs in 2001

7.1 Shunto: key historical statistics 184-5

8.1 Amakudari appointed regional bank executives: 1991-2000 210

8.2 The factors affecting amakudari appointments from MOF and BOJ to regional banks 216

9.1 Divorce, marriage, and family statistics among selected 225

9.2 Views on marriage and family among selected countries 225 


\section{Contributors}

Magnus Blomström is Professor of Economics at the European Institute of Japanese Studies, Stockholm School of Economics.

Thomas F. Cargill is Professor of Economics at the University of Nevada, Reno.

Lonny E. Carlile is Associate Professor of Asian Studies and Japanese Studies at the University of Hawaii-Manoa.

Janet Hunter is Saji Professor of Economic History at the London School of Economics.

Akihiko Kawaura is Professor of Economics at Doshisha University.

Sumner La Croix is Professor of Economics at the University of HawaiiManoa.

Chung H. Lee is Professor of Economics at the University of HawaiiManoa.

Curtis J. Milhaupt is Fuyo Professor and Director at the Center for Japanese Legal Studies, Columbia Law School.

Chiaki Moriguchi is Assistant Professor of Economics at Northwestern University.

Hiroshi Ono is Associate Professor at the European Institute of Japanese Studies, Stockholm School of Economics.

Kenji Suzuki is Associate Professor at the European Institute of Japanese Studies, Stockholm School of Economics. 


\section{Series editor's preface}

Asia is undergoing great changes, with the rise of the Chinese economy and the development of the economies in the Southeast Asian countries. One of the key questions of this century, and for the future of Asia, is where Japan, the economic giant in the region, is headed. Japan's future direction will be decisive for Asian development. Is Japan changing? Media and opinion leaders are divided on this issue and present little evidence of substance. Some call the 1990s a "lost decade" for Japan and claim that the country is unable to change itself and adjust to globalization of its economy, as well as to changes occurring in Asia. Others see far-reaching, albeit not readily visible, changes to Japanese society and the economic system, with implications for the future.

The aim of the authors of this book is to bring some substance and clarity into the debate on Japan's future role. They achieve this by looking at institutional change in Japan in a number of specific and strategically important areas such as financial institutions, corporate governance, employment systems, circulation of the elite between government and business, labour unions and even marriages and divorces. A historical perspective is achieved by comparing institutional change during the Meiji era with what is happening today, and a geographical one by comparing financial reforms in Japan with those that are undertaken in South Korea, Switzerland and New Zealand.

The chapters in this book are the result of a conference held in Hawaii, "Institutional Change in Japan: Why It Happens, Why It Doesn't", held at the East-West Center, Honolulu, Hawaii, when a number of experts on Japan from various disciplines gathered to present papers and discuss institutional change. Their conclusions do not provide a simplistic, clear-cut picture, but rather a multifaceted one that can still tell us something about Japan's future direction. The book provides something that, to a large extent, has been missing in the debate on Japan's change, or lack of change: a nuanced analysis based on facts and figures gathered and analysed by each scholar in his or her specific field of interest. We are proud to welcome this book into our series and believe that it will provide insights for scholar and layman alike, to anyone interested in what is now happening in Japan.

Marie Söderberg 


\section{Preface}

This book is the result of a long-term collaboration between the European Institute of Japanese Studies, Stockholm School of Economics; the Department of Economics, University of Hawaii-Manoa; and the East-West Center, Honolulu, Hawaii on structural and institutional change in Japan. Our earlier research focused on structural changes in Japan's economy during the 1990s. The present project investigates the evolution of economic and political institutions in Japan, with particular emphasis on the recent economic crisis. Institutional change is a vast topic. While our volume addresses only a limited number of issues, we hope that it will provide fresh perspectives on the slowly accumulating changes that are transforming institutions in twenty-first century Japan.

The Japan-United States Friendship Commission provided critical financial support for our project. We thank the Commission's Executive Director, Eric Gangloff, for stimulating discussions. Mindy Kotler of the Japan Information Project provided valuable suggestions on how to structure the project and was instrumental in helping us to organize a related forum in Washington, D.C. on "Fixing Japan's Economy."

We thank faculty from the University of Hawaii - Byron Gangnes, Theresa Greaney, David Johnson, Sang-Hyop Lee, James Mak, Andrew Mason, Jack Suyderhoud, and Sun Ki Chai - and research fellows from the East-West Center - Tianshu Chu, Rana Hasan, and Sheila Smith - who provided valuable comments on earlier version of these chapters at the Conference on Institutional Change in Japan held at the East-West Center. The Conference's smooth operation was due to the hard work of Mary Welsh, Irene Uemoto, and Carolyn Eguchi, who gave generously of their time over the New Year's holidays to assist with conference arrangements. We also thank Ron Cannarella for opening the Marco Polo penthouse to allow Hiroshi, Jody, and Sumner to view the spectacular New Year's Eve fireworks in Honolulu.

Several faculty and staff at the European Institute of Japanese Studies, Stockholm School of Economics, deserve special thanks. Annika Shelly worked diligently on shaping the manuscript into a style suitable for publication. Birgitta Schubert provided invaluable assistance to us and was very 


\section{xii Preface}

helpful in arranging Sumner's frequent visits to the Stockholm School of Economics. We also thank Marie Tsujita Stephenson for vital last minute assistance with manuscript preparation. Conversations with Ari Kokko and Fredrik Sjöholm helped to clarify key areas and to point us to important sources.

The editorial staff at Routledge provided us with speedy reviews, professional advice, and a new title. In particular, we acknowledge the assistance of Marie Söderberg, Editor of the East Asian Economics and Business Series at Routledge and Helen Baker, Editorial Assistant in Asian Studies at Routledge.

Magnus Blomström and Sumner La Croix

Tokyo

October 2005 


\title{
Introduction
}

\author{
Magnus Blomström and Sumner La Croix
}

Japan's prolonged economic stagnation has left many observers questioning the wisdom of Japanese economic organization and institutions. The current system is often viewed as so cozy and inflexible that reformers have been and will be unable to muster sufficient political power to force change until the system is confronted with a major crisis. Conventional wisdom, in both media analysis and academic research, is that a coalition of powerful political interest groups is blocking critically needed reforms, because these groups would lose wealth and power. This view provides, we argue below, a far too simplistic picture of institutions and institutional change in Japan.

This book analyzes recent changes in important Japanese institutions. It addresses the origin, development, and recent adaptation of core institutions, including financial institutions, corporate governance, lifetime employment, and the amakudari system. To place current institutional changes in perspective, it also includes discussion of both historical and international comparisons. Emphasis is placed on comparisons with Meiji Japan, a period in which Japan borrowed and adapted foreign institutions to its unique circumstances. Comparisons with recent economic and financial reforms in Korea, Switzerland, and New Zealand are also included to provide a broader perspective on the current reform process in Japan. The conventional wisdom is that Japanese institutions have remained relatively rigid since the collapse of the 1980s bubble, while our findings indicate that there has been significant institutional change over the last decade.

\section{Institutional change in theory and in practice}

In the opening essay, Sumner La Croix and Akihiko Kawaura review theories of institutions and reflect on their applicability to Japan. They begin by discussing Douglass North's $(2005,48)$ definition of an institution - "the formal rules, informal norms, and their enforcement characteristics" that determine how humans beings interact with one another in a given context. North (p. 60) makes a sharp distinction between institutions and organizations, with organizations being "groups of individuals bound 


\section{Magnus Blomström and Sumner La Croix}

together by some common objectives." Organizations compete to earn rents within the existing institutional structure (which sets the expected payoffs to actions) and also compete to make changes in the institutional structure which are to their advantage. To gain an advantage in both types of competition, organizations invest in skills and knowledge. This accumulation of human capital leads to incremental changes in institutions as well as changes in the way these groups of individuals view their world and social institutions. Because organizations exist within the complex, intertwined web of relationships with other organizations and institutions, institutional change is, in most cases, incremental and path dependent (North 2005, 62). Path dependence is a much debated concept, but fundamentally relates to the proposition that current choices "are constrained by the heritage of institutions accumulated from the past." Its importance stems from the presence of numerous organizations "whose survival depends on the perpetuation of those institutions and which hence will devote resources to preventing any alteration that threatens their survival" (North 2005, 51).

La Croix and Kawaura use this theory of institutional change to place Japan's "lost decade" in perspective. First, they note that Japan is not unique among industrialized countries in being slow to implement effective policy and institutional changes in response to a major crisis. This prompts an obvious question: Why do rich countries in depression wait such a long time to undertake needed reforms? One obvious reason is that their wealth and high per capita income provide households and firms with a hedge against hard times. This means that prolonged economic stagnation is less likely to cause a precipitous crisis that could force policymakers to undertake major reforms. With its high household savings rates and high household incomes, Japan fits this model well. The absence of a crisis in the 1990s that could have forced reform was a major factor in turning stagnation into depression.

A second reason, according to La Croix and Kawaura, is that by their very nature institutions cannot be too pliant. Institutions are a set of shared expectations about how individuals interact in a society, i.e. the shared perceptions of the rules of the game. Japan grew rich because its institutions were stable and functioned well, and it is to be expected that individuals would worry that change would bring expectations of further change and disrupt the stability that initially generated the prosperity. From this perspective, change will only be instituted when a large majority of individuals, firms, and the legislature become convinced that the existing institutional structure will never again function well and that there is an alternative which they are convinced represents a rational experiment for the society. La Croix and Kawaura note that many citizens and policymakers in Japan may not have perceived an obviously superior alternative institutional structure with which to experiment during the course of Japan's lost 13 years (1991-2003). 
A third reason is that countries become rich and stay rich because their governments had ongoing commitments to economic reform. Thus, when stagnation appears, policymakers reasonably believe that they are already undertaking reform measures that may be sufficient to carry the society back to robust growth. Policymakers and citizens rationally view most downturns as the product of unexpected, temporary, negative shocks, e.g. the sharp, temporary oil price shocks that have regularly punctuated the last 50 years, and believe that their impact can be mitigated with timely, expansionary monetary and fiscal policies. In this environment, policymakers are likely to initiate extensive reform programs only after monetary and fiscal policies have been tried and shown few timely results.

La Croix and Kawaura then consider a variety of additional explanations in the literature for Japan's slow change. First up is the emerging conventional wisdom that Japan has experienced difficulty in transiting between the institutions that facilitate rapid catch-up growth and those that allow for growth once the frontier of production and organizational technology has been reached. In these scenarios, Japan used commandand-control style regulation to facilitate resource allocation to industries that could imitate frontier technologies and compete on export markets. In some theories, Japan's lost decade occurs because of the difficulty in transiting from imitative to innovative institutions. In other theories, the economy declines because the deadweight losses from regulation have increased as the economy became more complex. According to La Croix and Kawaura, these theories suffer from the presumption that the developmental state was highly effective, and they present evidence questioning this widely held presumption.

La Croix and Kawaura also consider whether other theories of institutional change can explain Japan's post-1990 malaise. First, they consider a public choice analysis of Japanese politics; it places the ruling Liberal Democratic Party's drive to stay in power and multi-member legislative districts at center stage. Second, they consider the theory of institutional change propounded by Mancur Olson. Olson argued that established interest groups typically become more powerful over time and eventually retard economic growth. Third, they review Noguchi's theory that Japan's institutions were an artifact of central planning during World War II and were eventually doomed to reflect the usual flaws associated with central planning. Finally, they pay particular attention to Masahiko Aoki's theory of complementary institutions. Aoki believes that Japan's institutions evolved in an interlocking fashion, making it very costly to reform just one institution at a time. When changes in the economic, social, and political environment require institutional change, this becomes a complex process as it is necessary to have simultaneous reform of the complementary institutions. The high costs of institutional reform impart a rigidity to institutions that often serves the society well by providing the foundations for stable durable expectations and agreements. The rigidity is less 


\section{Magnus Blomström and Sumner La Croix}

advantageous when political, social, and economic changes produce a new environment in which reformed institutions would yield markedly better performance. In these cases, change is sometimes delayed until actors have reached consensus on how to change the interlocking institutions; or institutional change occurs sequentially, with the transition period being a dysfunctional mix of old and new institutions that do not function well together.

The second chapter, by Janet Hunter, analyzes the course of the Meiji reform process to indicate whether it might offer any lessons for institutional and organizational reform in Japan at the start of the twenty-first century. Hunter focuses on the presence or absence of short-run pressures for institutional change, the need to view institutional change as a long-run process rather than as a short-run event, and the role of the state in engineering institutional change.

The substantial institutional and organizational changes in Japan that followed the Meiji Restoration of 1868 have often been portrayed by historians as an unmitigated success story. Hunter argues, however, that the reality of the Meiji transformation was invariably more problematic than the successful image often portrayed. Analysis of the Meiji experience provides insights into three key areas at the heart of current debates in Japan financial institutions, business enterprises, and the labor market. Hunter suggests that, in all three cases, the process of institutional and organizational change before World War I was slow and sporadic. It is notable that the uneven nature of this transformation came against the backdrop of a sense of national urgency - that Japan had to develop economically or face domination by Western powers - and of the strong political will of the Meiji Emperor. Hunter suggests that great caution needs to be exercised in drawing any lessons for contemporary Japan from the Meiji experience, but is able to draw two tentative conclusions. First, the Meiji transformation, successful as it was, cautions us that it is unrealistic to expect fundamental institutional change within a very short time span. Second, the relative merits of importing new institutions and modifying existing ones are rarely clear cut. Application of her analysis to modern Japan must also be tempered by noting the vastly different international environments that Japan faced 140 years ago and that she faces today.

In Chapter 3, Chung Lee compares institutional changes in Japan and Korea. In contrast to Japan, South Korea undertook speedy economic reforms soon after the 1997-98 crisis. According to Lee, the difference in the reform experiences across the two countries may be that in comparison to Korea, Japan is a rich country and has been suffering from an economic malaise, not a severe economic crisis. For example, at the height of the 1997-98 East Asian Financial Crisis, Korea faced the specter of being unable to service its short-term debt obligations. This threat forced Korea to accept an International Monetary Fund loan with conditional requirements that forced rapid reforms. Japan was also impacted by the Crisis, yet 
during the lost decade of the 1990s Japan continued to run current account surpluses and thus was not forced to adapt its policies and institutions.

Lee then argues that there is another rather critical factor that accounts for the differences between Japan and Korea: For a country to change its institutions, the advocates for change need to have a model of institutions that the advocates for change and the society at large can understand and accept as a model that is superior to the extant institutions. Japan has gone through two major institutional reforms in its modern history - the Meiji Reform of 1868 and the post-World War II reform. In those two cases Japan was compelled to reform its institutions by outside forces and had definite models to follow. This time the situation is different: given that Japan has successfully caught up with the West with a political-economic system that is often claimed to be uniquely Japanese, many in Japan, even those who advocate a systemic reform, lack a clear vision or a model for institutional reform. Japan is now in a paradigmatic crisis, a crisis that has shaken the beliefs held by many Japanese about the wisdom of their political-economic system, and is in need of finding an alternative paradigm that the people can accept - a process that inevitably takes a long time. By contrast, in Korea, even before the crisis of 1997-98 there was a strong move to establish a liberal economic order, and the crisis served as a catalyst for reforms that had already been widely discussed and in some cases partially implemented.

\section{Recent changes in Japanese institutions}

The first Japanese institution examined in this volume is corporate governance. In Chapter 4, Curtis Milhaupt examines all major changes in Japanese corporate law and in corporate practice, which typically lags behind changes in corporate law. He shows that analysis of Japanese corporate law reveals a striking amount of formal institutional change since the early 1990s and that it is occurring at an ever-accelerating pace. This feature of law reform can be traced to a heightened awareness of the organizational straightjacket imposed on Japanese firms by the Commercial Code, and to a more competitive and market-responsive environment for the production of corporate law. It has been a "sea change decade" for Japanese corporate law.

Milhaupt also claims that it has been an ambiguous decade for Japanese corporate practices. Signs of change in response to the new institutional environment can be found in the areas of shareholder activism, corporate mergers and acquisitions and other organizational changes, board structure, and corporate finance. At the same time, however, domestic institutional investors remain passive, management remains largely insulated from the market for corporate control, and "lifetime" employment practices, while covering a shrinking subset of the Japanese workforce, remain firmly in place. 


\section{Magnus Blomström and Sumner La Croix}

Milhaupt accounts for the observed pattern of change and rigidity by analyzing the political economy of corporate law reform, the complementarities at work between corporate law and other institutions, and the relationship between corporate law and corporate governance. Japanese corporate law has become more adaptable and responsive to "demandside" impulses, but it also increasingly reflects the interests of Japanese management, an organized group potentially threatened by corporate law reform. Without external pressures, Japanese managers are able to use the newfound flexibility of the corporate law to entrench themselves as well as to improve returns to shareholders. Moreover, while Japan's corporate law has improved, several complementary institutions needed to complete the institutional package are still incomplete. Ultimately, corporate law bears only a limited relationship to corporate governance. Changes in corporate practices are brought about by dynamics external to the formal corporate governance institutions. Thus, according to Milhaupt, the sea change in Japanese corporate governance must await further changes in the distribution of shareholders, in the capital markets, and in the incentive structures for management, as well as the further erosion of corporate norms that promote employee and managerial interests over shareholder interests.

In Chapter 5, Thomas Cargill reviews the reasons for Japan's failure to resolve fully the economic and financial distress that started in 1990 with the collapse of asset prices. Despite the many efforts to stimulate the economy and redesign the financial system, the recent recovery has proven to be very fragile, and most observers are worried about its durability. Cargill then poses a worrisome question: Is Japan entering into a second lost decade in terms of economic and financial development?

Cargill opens by providing a general framework or taxonomy of financial reform as a background for exploring the failures of financial redesign in Japan. His central theme is that resistance to institutional redesign is normal and that one can reasonably identify those factors responsible for differing policy outcomes across countries. While the United States and Europe have been able to overcome resistance to institutional change, Japan has been unable to accomplish this, perhaps because the resistance has deep roots in the ruling Liberal Democratic Party.

Cargill also discusses restraints embedded in Japan's financial system that account for the slow and incomplete reform process. These are referred to as country-specific restraint factors, because they reflect the basic foundations of the old Japanese financial regime. He then considers a variety of explanations for Japan's continued reluctance to reform its financial system, including: moral hazard affects Japan's financial system less directly than in other countries; Japan's banks have been successful, so why should they undergo reform; Japan has not faced a crisis so there is no pressure for reform; liberalized financial systems are incompatible with Japan's culture and belief systems; and changing Bank for International 
Settlements capital requirements have held up or reduced the necessity for reform.

Cargill then turns to general or global restraints to reform and focuses on policies adopted by the Bank of Japan and the adverse effects of deflation. Explanations for the tight monetary policy of the Bank of Japan, especially since 1995 , are explored and the impact of deflation on the economy is identified. He then discusses three issues related to the reform process: First, the difficulties created by government financial intermediation for establishing a deposit guarantee system consistent with financial stability; second, the lack of sustainability of the old regime; and third, the diminishing window of opportunity for dealing with economic and financial distress because of the demographic changes that are rapidly transforming Japan.

In conclusion, Cargill argues that Japan's difficulties in reforming its financial system are not due to a lack of resources or a lack of understanding about the sources of the problems and the changes that need to be undertaken. Cargill is confident that Japan has both the capability and the knowledge to enact and implement the changes needed to restore the economy and financial system to stability and sustained growth. He claims that institutional redesign is a matter of will and political leadership and that, to date, Japan has not shown a willingness to accept the cost of reform and continues to engage in forgiveness and forbearance. According to him, Japan need not adopt a Western-style financial system modeled exactly on the lines of those in the United States or Great Britain. It does, however, need to find a way to depart from its reliance on mutual support to resolve problems in the banking system and to develop a system that allows for bankruptcy to play a more meaningful role in the allocation of resources.

Another important Japanese institution is the system of lifetime employment. In Chapter 6, Chiaki Moriguchi and Hiroshi Ono examine the origins and dynamic evolution of the lifetime employment system in Japan from the beginning of the twentieth century to the present. Based on the historical perspective developed in the paper, they derive implications for the future course of the Japanese employment system. Moriguchi and Ono view lifetime employment as an economic as well as a social institution, characterized by an implicit contract and reciprocal exchange of trust, goodwill, and commitment between employers and workers. They argue that this institution emerged as an equilibrium outcome of the dynamic interactions among management, labor, and government and became an integral part of the nation's employment system over the past hundred years, reinforced by complementary institutions such as state welfare policies, labor laws, corporate governance, social norms, family values, and the education system.

The historical analysis surveys how employment relations evolved from spot contracting toward implicit and long-term contracts. Lifetime 


\section{Magnus Blomström and Sumner La Croix}

employment traces its origin back to the prewar years. The practice emerged among leading zaibatsu firms in response to economic conditions during the interwar period and diffused under the wartime government regulations. The employment practice was fundamentally reshaped during the years of the U.S. occupation after World War II, and was firmly established and socially embedded during the high-growth period. The lifetime employment system persisted through both supply-side shocks (e.g. labor shortage during economic prosperity) and demand-side shocks (most notably the oil crises) to labor markets. More recently, however, the practice has been under serious threat as the economy plunged into a recession in the 1990s. There is now widespread criticism that the practice undermines efficient resource allocation, and a majority of Japanese firms claim that the practice can no longer be sustained.

Moriguchi and Ono also document the formation of complementary institutions that reinforced and institutionalized the lifetime employment practice. Most notably, the lifetime employment practice evolved concurrently with collective bargaining through enterprise unions and corporate governance based on stable shareholders. State welfare policies, such as national health insurance, pension, and unemployment insurance, developed complementary to corporate welfare provisions since the 1930s. The courts accumulated case laws that restricted employers' rights to dismiss since the 1950s, citing employers' social responsibility to provide employment security and a minimum standard of living. Workers who changed their employers came to be socially stigmatized, which discouraged the development of external labor markets for mid-career job seekers. The lifetime employment system, confined to core employees in relatively large firms, gave rise to sharp distinctions between regular and non-regular employees within firms, as well as the division of labor along the gender line, inhibiting career prospects for a majority of Japanese females.

Based on their long-run historical analysis, Moriguchi and Ono reevaluate the cost and benefit - both in economic and social terms - of the lifetime employment system and explore the factors that determine its efficiency and stability. They emphasize the importance of understanding labor market conditions, technology and the nature of human capital, interactions between social and economic aspects of employment relations, and the role of complementary institutions. The chapter concludes by assessing changes in these factors in the post-bubble period, offering some insights to the future course of the Japanese employment system.

Labor unions are organizations that influence and are influenced by institutional changes. In Chapter 7, Lonny Carlile traces the evolution of the Japanese labor movement's stance toward institutional change from the early post-World War II era to the present and argues that, like most labor movements, the Japanese movement began as a movement that promoted the wholesale reconstruction of national political economic 
institutions. The emergence of a "productivity bargain" at the firm level, the institutionalization of the Shunto wage bargaining system, and the employment security provided to the bulk of the unionized workforce through the Japanese lifetime employment system combined to moderate the stance of organized labor towards Japan's economic institutions.

Over time, Carlile argues, the labor movement's role vis-à-vis institutional change shifted. In the late 1970s, the stance of the Japanese labor movement shifted, as it became generally supportive of the institutional status quo in the industrial relations arena. Outside of the industrial relations arena the labor movement, together with big business, emerged as a force pushing for deregulation and privatization. By the 1970s, rather than being a force devoted to precipitating wholesale institutional change, the Japanese labor movement shifted to a stance of active defense of the institutional status quo in both industrial relations and the Japanese political economy writ large. In the late 1990s the overarching union organization, Rengo, showed signs that it was once again altering its stance in reaction to government and management assertions that many Japanese corporations had "excess" labor and that layoffs could serve to improve corporate efficiency.

Carlile uses the concept of "social contract" to make sense of these shifts in the labor movement's stance toward institutional change. $\mathrm{He}$ argues that the earlier shift, from promoting institutional change to defending the status quo, can be understood as a byproduct of the establishment of a social contract acceptable to organized labor that was forged between business, labor, and government in the 1960s. The initial steps taken in the late 1990s to alter that stance are seen as a consequence of a perceived breakdown of that social contract precipitated by Japan's prolonged recession of the 1990s and increased international competitive pressures. Carlile sees the latest changes in stance as an attempt by organized labor to forge an alternative vision of Japanese society that moves away from the firm-centered collectivism of the Japanese employment system to one in which the state intervenes more directly in assuring the welfare of the individual.

The Japanese institution of elite circulation between government and business, known as amakudari, is investigated by Kenji Suzuki in Chapter 8. This reemployment of officials retired from the government into senior management positions in private companies is one of the most famous informal institutions that are frequently mentioned in the literature on Japanese political economy. In his study, Suzuki focuses on the reemployment of high-ranking bureaucrats from the Ministry of Finance and the Bank of Japan in regional banks on their retirement from their government posts. He carefully discusses the mechanism of amakudari appointments and how this mechanism has gradually changed over time.

Four different perspectives (human resource, communication, monitoring, and compensation) are presented, and their validity is tested by an 


\section{Magnus Blomström and Sumner La Croix}

empirical analysis with annual panel data from 96 regional banks over the period 1991-2000. His results support the hypothesis that the appointment of a retiree from a ministry to a regional bank upon the retirement of a predecessor from the same ministry - a chain appointment - has recently become less likely. On the other hand, Suzuki also finds that amakudari appointments are more likely to occur at banks which are safer and generally more profitable than other banks. He argues that this supports the traditional view of the amakudari system, that it is used to provide extra compensation to retired bureaucrats.

The final chapter, written by Hiroshi Ono, examines the social institution of marriage through the lens of divorce. Divorce provides a good example of a normative shift that often accompanies institutional change and which usually has its roots in economic and demographic pressure. In his chapter, Ono addresses two empirical questions about divorce in postwar Japan: Why is the divorce rate so low compared to other industrialized economies? And, why is it rising?

He examines patterns of marriage and divorce in Japan as a process of institutional change and ties it to the changing economic roles of men and women. When the Japanese economic miracle began in the 1950s, the practice of lifetime employment strongly favored men over women. Men were expected to be highly committed to their job and women to their family. Tax and benefit programs, prevalent social norms and the exclusion from lifetime employment combined to relegate women to part-time low-paying jobs, making them extremely vulnerable in the event of a divorce.

Ono then discusses how the rising divorce rate in Japan is an outcome of the dynamic interactions between economic development and demographic change at the macro-level, and changes in social norms and attitudes that govern the behavior of individuals at the micro-level. Since 1975 the legislative and social movements promoting equal status between the sexes in Japan has narrowed the dependency between the spouses, allowed women greater voice, and lowered the cost of exiting a marriage. The diversity of family forms, such as civil unions and cohabitation, has allowed couples to choose alternatives to marriage, which in turn weakens the institution of marriage.

Demographic change has been one of the major forces generating institutional change since the beginning of human history (North 2005). Japan's rapidly declining birthrate - registering just 1.29 births per woman in 2003 - is clearly associated with the increasing divorce rate, although the direction of causation is far from clear. With the secular decline in the birthrate, the couple is, at any given age, less likely to have any children, and is more likely to have fewer children. Because one of the main costs of divorce is the cost imposed on the children - a cost that will be somewhat considered by the parents - having fewer children or no children at all lowers the cost of divorce. On the other hand, if women perceive that the 
marriage is more likely to end in divorce, then they are also less likely to have children.

\section{Conclusion}

Japan is changing, albeit not as rapidly as some might prefer. The pace and extent of institutional change across different aspects of the economy and society has been very uneven. We are not surprised. Japan is a consensus society, and change requires extensive consultation and often the mustering of a considerable majority before policymakers will move to make changes. Japan's achievement of remarkable economic growth over the 1952-73 period must not obscure its equally remarkable achievement of narrowing per capita income differentials both within and across prefectures. It's not surprising that the Japanese are reluctant to abandon their economic institutions for Anglo-Saxon replacements that they associate with increased inequality.

Curtis Milhaupt's observation that corporate law has changed but corporate practice lags behind, is a critique that could be aptly applied to many other Japanese institutions. The norms that built up around Japan's unique employment, corporate, and financial institutions are not ones that will disappear overnight. Still, as labor market institutions for the "aftermarket" of laid-off salarymen in their forties and fifties begin to function more effectively, we are likely to see the norms associated with the old regime make, at some point, a fast exit. When this happens and the new legal institutions become more effective, Japan will finally be able to make more sense of its evolving economic, political, and social institutions.

Thomas Cargill's lucid discussion of how financial system reforms have been coupled with ancien regime norms parallels the discussion by Curtis Milhaupt. Changes in norms have once again lagged behind changes in a critical Japanese institution. But not just any institution: an institution that by all accounts plays a critical role in any economy. Understanding changes in the financial system clearly involves a much deeper understanding of the role of bureaucracy in institutional change in Japan, and that is still an understanding that we do not possess.

There are puzzles, however, that we have not come close to addressing. It's easy to see why the Japanese have not addressed the looming problems in their social security system. The public pension systems of Germany, France, and Italy, all speeding towards a collision with demography, have been equally resistant to change. As in Europe and North America, analysts have correctly warned that early reforms will be painful, but much less painful than delayed reforms (Horioka 2001). Regardless, in a country with a declining population, and a national consensus that immigration must be limited, the national reluctance to address this problem is one that strains theories of institutional change.

Our analysis has also done little to address the reasons for and the 


\section{Magnus Blomström and Sumner La Croix}

implications of Japan's remarkably low birthrate. Hiroshi Ono touches on some of the reasons for Japan's declining birthrate in his essay, and a battalion of demographers continues extensive work on this issue. Demographic change has, however, been at the heart of institutional change throughout history. Usually downward demographic change has been due to the Malthusian ravages of "war, pestilence famine or the convulsions of nature." Japan's downward fertility spiral is due to choices by affluent couples, an unprecedented event in history. As with previous demographic changes of large magnitude, it is sure to induce far-reaching institutional change throughout the society.

\section{References}

Horioka, Charles. (2001). "Japan's Public Pension System in the Twenty-First Century," in Magnus Blomström, Byron Gangnes, and Sumner La Croix, eds, Japan's New Economy: Continuity and Change in the Twenty-First Century. New York: Oxford University Press.

North, Douglass C. (2005). Understanding the Process of Economic Change. Princeton: Princeton University Press. 


\section{Part I Institutional change in theory and practice}





\title{
1 Institutional change in Japan Theories, evidence, and reflections
}

\author{
Sumner La Croix and Akihiko Kawaura
}

\section{Introduction}

I Love You, You're Perfect, Now Change is the title of a long-running offBroadway musical in New York City that chronicles the course of love and marriage. One could forgive Japanese visitors if they surmised from the title that the show was actually about the changing perception of Japan in Europe and North America. In the 1980s, the Japanese economy registered strong income growth; the yen soared in value; high domestic savings rates allowed massive investments overseas; soaring equity and land values commanded daily media attention; and Japanese economic institutions and business practices were lavished with praise (and sometimes vilified) by the Western media. North American and European firms and governments studied the Japanese experience closely to see what aspects of Japanese business practices and institutions they could adopt to improve their own performances. In the 1990s, the love affair with Japanese institutions was shaken when Japan's economic bubble burst. Land and stock market prices began a precipitous fall in 1990 that only leveled off in the 2003-05 period; real income growth was low and volatile for over a decade (1991-2003); deflation in consumer prices from 1995 raised anxiety among foreign and domestic observers that the economy was on the verge of collapse; and massive losses on overseas investments, e.g. in Hawaii and New York City, sullied Japan's image as an economic superpower with a uniquely long vision in making investments. Calls of Now change! began to resound both inside and outside of Japan after 1995. Yet within just a few years the academic and media chorus began to repeat a new refrain: Why doesn't Japan change? Why doesn't Japan reform its unique economic and political institutions, remolding them around the successful models observed in Great Britain and the United States?

Our challenge in this essay is threefold. First, we provide a brief overview of the theory of institutions and institutional change, with considerable emphasis placed on Douglass North's recent formulation of these issues in his book, Understanding the Process of Economic Change (2005). In particular, we spend considerable space discussing the concept 


\section{Sumner La Croix and Akihiko Kawaura}

of "path dependence" as we believe that it is critical to an understanding of Japan's contemporary institutions.

Second, we closely examine the assumptions underlying the initial calls for institutional change and set forth the process by which such change would proceed. We identify four critical assumptions: (1) the underlying reason for Japan's economic stagnation is that its economic institutions had become obsolete and were no longer capable of generating efficient outcomes; (2) large-scale rather than incremental institutional change was required; (3) the institutional changes could be proposed, enacted, and implemented relatively quickly; and (4) the new institutions would quickly become effective, raising GDP growth within a relatively short period of time. Our analysis critically examines these assumptions and finds that many of them are highly problematic, even in a highly idealized setting. We briefly ponder whether major institutional changes could have been carried out successfully if there had been strong leadership in political, business, and labor arenas pushing for the changes.

Third, we analyze the question Why doesn't Japan change? from a number of critical perspectives. We begin by critiquing the conventional wisdom, that a coalition of powerful, political interest groups is blocking critically needed reforms because these groups would lose wealth and power. Because the current system is so cozy and inflexible, it is commonly argued that reformers have been and will be unable to muster sufficient political power to force change until the system is confronted with a major crisis. We argue that the conventional wisdom captures essential elements of an answer to the question, yet also provides a far too simplistic portrayal of the determinants of institutional change in Japan in the first decade of the twenty-first century.

We then question the basic premise behind the question Why doesn't Japan change? and consider whether there really has been little or no institutional change in Japan. As do several other authors in this volume, we argue that Japan has been undergoing incremental change since the early 1980s and that such change is harder to discern and evaluate because of its incremental nature, slow pace, and the continuing economic stagnation. Rather than only asking why Japan does not change, we should also be examining how Japan is changing and whether these changes are likely to be sufficient to generate a new set of social institutions that will be flexible enough to allow Japan to weather and adapt to its current pressing challenges: the shocks of globalization, the dramatic demographic shift in the age structure and size of its population, and the meteoric rise of two new Asian giants, China and India. We analyze several strategies that the Japanese government has been using to trigger institutional change and reflect on why several institutional changes, considered by many analysts to be critical components of stimulating economic growth in Japan, have not been implemented. 
We proceed as follows. We first provide a brief survey of the theory of institutions and an overview of a variety of different analyses of Japan's unique institutions. We then focus more specifically on the theory of institutional change and confront the questions of whether these theories are likely to be applicable to Japan, before drawing our conclusions.

\section{Institutions: theory and applications to Japan}

\section{The New Institutional Economics: an introduction}

"Institution" is a commonly used word that could refer to an organization that plays a prominent role in society, e.g. Sony Corporation, the Japanese Diet, Tokyo University, or it could refer to the sets of rules, norms and expectations which guide our behavior. In the New Institutional Economics, it is the second use of the word that dominates, although there are significant variations in its usage by its practitioners. One group, which includes Douglass North and Leon Hurwicz, defines institutions as

The humanly devised constraints that structure human interaction. They are made up of formal constraints (e.g., rules, laws, constitutions), informal constraints (e.g., norms of behavior, conventions, selfimposed codes of conduct), and their enforcement characteristics.

(North 1994, 360)

A second group, which includes Andrew Schotter, Avner Greif, and Masahiko Aoki, considers institutions to be the equilibrium outcome of a game. Aoki (2001) defines an institution as a shared, self-sustainable, summary expectation held by agents of the way in which a game is repeatedly played in a certain domain.

Regardless of which definition we adopt, institutions arise because individuals face an environment with multiple sources of uncertainty, and they have an "ubiquitous drive to make their environment more predictable" (North 2005, 14). Ronald Coase $(1937,1960)$ made this point in a more limited context in his seminal articles on the relationship between markets, firms, and legal rules, arguing that in a world with zero information and transaction costs there would be little need for firms or for legal rules to structure transactions. In a world with imperfect and asymmetric information, environmental shocks (e.g. floods, earthquakes, droughts, etc.), and technological innovations, humans construct institutions to structure their responses to these events and with each other. By structuring the way the game is played among human beings, institutions allow individuals to face a more secure environment, albeit at the cost of encountering a more complex human environment.

North sets forth a concise representation of the broad scaffolding that constitutes the institutional framework of modern societies: 


\section{Sumner La Croix and Akihiko Kawaura}

The institutional framework consists of the political structure that specifies the way we develop and aggregate political choices, the property rights structure that defines the formal economic incentives, and the social structure - norms and conventions that defines the information incentives in the economy. The institutional structure reflects the accumulated beliefs of the society over time, and change in the institutional framework is usually an incremental process reflecting the constraints that the past imposes on the present and the future. All this and more - makes up the structure that humans erect to deal with the human landscape.

(North 2005, 49)

North (p. 60) makes a sharp distinction between institutions and organizations, with organizations being "groups of individuals bound together by some common objectives." Arising as an endogenous response to incentives provided by the institutional structure, organizations compete to earn rents within the existing institutional structure and to change the institutional structure to their advantage. To gain an advantage in both types of competition, organizations invest in skills and knowledge. This accumulated human capital leads to two critical results: (1) it allows some organizations to be successful in their initiatives to change the institutional structure; and (2) it changes the way in which organizations and their members perceive and evaluate the institutional framework.

The second point is critical, as much institutional change can only move forward when it is approved by legislators, judges, regulators, or the executive. They, in turn, must be convinced that existing institutions have become inefficient; that there is a better alternative which can be implemented in a timely fashion; and that they will be able to convince constituents of these points. A number of factors - specific investments by organizations in the existing institutional framework; interlocking institutions; uncertainty concerning how alternative institutions might work; and the transaction costs associated with the process of institutional change combine to ensure that in most cases institutional change is incremental, proceeds at an uneven pace, and is path dependent (North 2005, 62).

The basic theory of group adaptation and environmental selection is compelling in the context of a free and open civil society, but one can surely question how easy it is in many countries for new groups, particularly splinter groups, to enter civil society and prosper therein. Governments typically treat various groups in civil society very differently, thereby raising significant barriers to entry. Existing groups frequently take action to raise costs for potential new rivals. Network externalities may mandate that a new group enter civil society at a very large scale if it is to be effective. In general, all of the factors that lead to restricted competition in product markets are also present in civil society. And, as in product markets, the presence of barriers to entry and externalities elimi- 
nates the standard result that competition will necessarily lead to an efficient allocation of resources.

Path dependence is a much debated and controversial concept. In economic history, the concept usually refers to the remarkable durability of past institutional choices; it is encapsulated in the proposition that current choices "are constrained by the heritage of institutions accumulated from the past." North $(2005,51)$ maintains that path dependence stems from the presence of numerous organizations "whose survival depends on the perpetuation of those institutions and which hence will devote resources to preventing any alteration that threatens their survival."

The original debate over whether path dependence "mattered" centered around the evolution of technological standards within the marketplace. Paul David (1985) argued that the QWERTY layout seen on almost all typing keyboards had become the standard layout despite strong evidence that other layouts would raise the productivity of typists. David asserts that the only reason why young typists learn to type on QWERTY keyboards is because most keyboards they are likely to use have the QWERTY layout. Stan Leibowitz and Stephen Margolis have questioned the quality of the evidence showing that non-QWERTY keyboard layouts are more productive, and David (1997) has responded by defending and extending his original analysis. ${ }^{1}$ While one may or may not be fully persuaded by the Leibowitz and Margolis defense of the productivity of the QWERTY standard, they also provide several clear-cut examples showing that other industry standards have quickly faded when consumers are presented with new, more preferred technological standards despite the presence of an extensive stock of capital embodying a different standard. Examples include the rapid replacement of Beta tape players with VHS tape players in the late 1980s; the rise of IBM-type PCs in the mid-1980s despite the dominance of Apple PCs with a different operating system; and the rapid transition from the WordPerfect word processor to the Microsoft Word word processor.

Path dependence may, however, have more currency when it is applied to the institutional framework rather than to technological standards, as competing institutional standards cannot just enter the "market" and compete with existing institutions. In many cases, changes must be approved by one or more political entities, providing losing organizations with opportunities to block the changes. We illustrate this with two wellknown examples of path dependence from North (2005) and Daron Acemoglu et al. (2001).

North $(2005,144)$ uses the concept of path dependence to analyze the source of Spain's long decline from the seventeenth century into the second half of the twentieth century. Spain was formed when two previously independent kingdoms, Castille and Aragon, united in the late fifteenth century under Queen Isabella and King Ferdinand. Aragon had a strong Cortes with significant representation from merchant groups, while 


\section{Sumner La Croix and Akihiko Kawaura}

Castile had a weak Cortes, no "heritage of strong merchant groups," and had been engaged in prolonged internal and external warfare. Without strong interests to counter Queen Isabella's consolidation of authority, it is unsurprising that Castile emerged as a bureaucratic, centralized monarchy. North argues that the centralized monarchy was the major factor behind Spain's decline and that Spain's use of centralized, bureaucratic institutions in South America played a central role in its institutional evolution.

Acemoglu et al. (2001) have argued that contemporary political and economic institutions in countries previously colonized by Europeans frequently retain the broad features of the original institutions established in the country. Their hypothesis is that the type of institution established in each country was broadly related to settler mortality in those countries. In colonies with high settler mortality, e.g. West Africa, Indonesia, and South Asia, institutions were put in place to extract the wealth of the colony rather than to maximize the welfare of the host population. By contrast, in colonies with low settler mortality, e.g. New Zealand, North America, institutions were put in place by European governments that facilitated wealth creation by the European settlers. ${ }^{2}$ A sophisticated (albeit much criticized) econometric analysis supports their hypothesis. ${ }^{3}$

Path dependence has implications for analysis of contemporary institutions, as it carries with it the possibility that the dead hand of institutions designed and evolved to serve a past society - may be impairing the functioning of contemporary institutions. It is not surprising that notions of path dependence are raised during times of rapid social and economic change, as slow institutional change and consequent sluggish economic performance leaves observers searching for their sources.

Path dependence occurs because transaction costs - the costs of defining, measuring, and enforcing a transaction - associated with institutional change are nontrivial and typically serve as impediments to rapid or jolting change. Transaction costs play a significant role in three different varieties of institutional analysis, all of which begin by placing the transaction at the center of their analysis. The three perspectives are differentiated by their treatment of government and the potential for welfare losses within the system. The first perspective, exchange-supporting institutional analysis, finds its fullest expression in Oliver Williamson's pathbreaking 1985 book, The Economic Institutions of Capitalism. It contained the fundamental insight that as transactions grow in complexity, additional resources must be devoted to ex ante contracting and to ex post governance. It lays the basis for the insight that high-income economies will devote a higher percentage of their income to the contracting process and in most cases will lead to growth in the resources allocated to government. North and Wallis (1986) provided empirical foundations by estimating the percentage of U.S. national income devoted to supporting transactions. Their finding that it had increased rapidly in the twentieth century was consonant with other emerging theories arguing that growing transaction complexity 
required an expanding government to define and enforce the new nexus of property rights and contracts. Economists writing in this tradition also see the potential for welfare losses from misguided policies and obsolete institutions, which can be corrected if individuals are made aware of the losses and the gains from alternative arrangements.

A second, closely related perspective, constrained efficiency analysis, developed in the 1970s and the 1980s at the University of Chicago and University of Washington also places the transaction at center stage and spends considerable effort to show that institutions and government policies typically evolve to minimize deadweight losses in the system. Economists writing in this tradition (Stigler 1975; Becker 1983; and Barzel 1997) have emphasized that rules formulated by government tend to be efficient once we have carefully taken all constraints into account. For example, Gary Becker and George Stigler have emphasized that economic policies and institutions which are seemingly inefficient at first glance often must be re-evaluated once we take into account a second objective: transferring income. For example, a minimum wage both generates deadweight losses and transfers income to certain groups of low-income workers. They assert that once we take into account the deadweight losses from alternative methods for transferring income (increases in the marginal income tax rate, social welfare programs, etc.), the policymakers' choice of a minimum wage is efficient. If this choice were actually inefficient, i.e. a more efficient policy can be implemented with the welfare gains greater than the costs of implementation, then, in Mancur Olson's words, there would be "money left on the table" and organizations would have incentives to strike bargains to appropriate these rents.

A third perspective, public choice analysis, also places the transaction front and center, but has a much more harsh view of government (Buchanan and Tullock 1962; Rowley et al. 1988). It models the decisionmaking process of government officials and representatives and finds that they make decisions which maximize their own utility rather than the overall welfare of society. Rules are promulgated which, rather than supporting exchange, constitute barriers to exchange and create rents for particular organizations competing within the institutional structure and for some in government. High transaction costs of understanding the implications of the rules, monitoring government officials, and organizing political support for the alternatives prevent clearly superior alternative rules from being implemented. Economists writing in this tradition argue that this process could be short-circuited by constitutional requirements restricting the power of governments to engage in such actions.

\section{Applications to Japan}

From 1953 to 1972, Japan's economy grew at an average annual rate of 8.2 percent, rising from the ashes of wartime defeat into the elite group of 


\section{Sumner La Croix and Akihiko Kawaura}

developed countries. This performance occurred within an institutional framework that coalesced between 1952 and 1962 and would remain in place for another 25 years. The framework included lifetime employment for male workers at major manufacturing and service corporations (Moriguchi and Ono, ch. 6 this volume); corporate governance institutions that emphasized the role of main bank monitoring of managerial performance and deemphasized monitoring by equity holders (Milhaupt, ch. 4 this volume); cross-shareholding to prevent hostile takeovers; extensive government intervention in the financial sector to ensure that capital was allocated to infrastructure projects and industries favored by the government (Cargill, ch. 5 this volume; Doi and Hoshi 2003); technology policies designed to ensure that technology is broadly distributed within Japanese industries; and close cooperation between industry associations and the government bureaucracy.

\section{Complementarity of institutions}

One characteristic of the Japanese institution that is crucial in the assessment of potential for its change is complementarity among its various subcomponents. Osano and Serita (1994) offer a model that incorporates strategic complementarity in the choice of financial and employment contracts. Their discussion emphasizes that Japanese industrial relations include lifetime employment contracts with deferred compensation plans and investment in the firm-specific human capital of workers that would be sunk should the employees leave the company. The main bank provides insurance to workers that the implicit agreement on their deferred payments will be honored by increasing the probability of the firm's survival. Corporate governance institutions reduce monitoring of management by shareholders and prevent them from breaking the wage bargain.

Aoki (2001) presents a comprehensive account of Japanese economic institutions. Aoki argues that diversity in economic systems is natural due to the bounded rationality of economic agents, the asymmetric distribution of information among agents, incomplete markets, and different environmental characteristics. In this context, there cannot be any single ideal economic system holding over time and space. Aoki's models typically generate multiple equilibria; history and the institutional environment surrounding the domain of the game often dictate which of the equilibria will actually be observed. Institutional complementarity plays a central role in his theory of Japanese economic institutions, with lifetime employment, the main bank system, and government regulation being closely interrelated. His models generally are designed to highlight the incentives of economic actors within economic institutions and usually do not incorporate political economy considerations explicitly.

Aoki believes that the Japanese economic system encourages investment in "contextual skills" that are useful in the context of a particular 
organization; their value cannot be assessed in the external market. Further, in these firms with an assimilated or shared information structure, teamwork is the typical mode of operation and no individual's contribution to the organization can be clearly identified. On the other hand, the American system emphasizes functional skills determined by the market and thus can be assessed in the external market. Aoki's models thus lend room for institutional diversity across economies and institutional specialization. The institutional diversity could, however, be upset by increased market integration, technological change, or reductions in the costs of monitoring worker effort.

Consider a marriage between Aoki's theory and the gradual reduction of global trade barriers over the last 50 years. Suppose that Japan also possesses some industries that would be best organized under the American system but are forced by Japan's overarching economic institutions to be organized under Japan's system. In many cases, these industries would not survive international competition but for protection. As trade barriers have fallen and more goods and services have become tradable over the last 30 years, many of these industries have faced increased competition from developing countries in Asia and have rapidly declined. With their decline and the slow movement of resources to other industries in which Japan has a comparative advantage, Japan's growth rate declines. This theory would note the close correspondence between Japan's slowdown and the rapid import of low-cost goods from Southeast Asia, many from transplant firms.

\section{Path dependence}

Robert Higgs (1987) studied the growth of government in the United States during the nineteenth and twentieth centuries and concluded that a major source of this growth was the expansion and exercise of emergency powers during wartime. Higgs places particular emphasis on World War I, the subsequent Red Scare, the Great Depression, World War II, and the Cold War as critical episodes leading to expansions of emergency powers. While the federal government typically gave back some powers in the aftermath of its wars, Higgs concluded that each succeeding peacetime period experienced a overall ratcheting-up in the scope and scale of government power compared to prior peacetime periods. Higgs argued that this increase in government regulation had the effect of reducing both economic growth and economic freedom. In sum, Higgs believes that path dependence is particularly important in understanding institutional change in countries experiencing frequent, deep national crises.

Can some of the growth in government and regulation in Japan be attributed to Higgs' ratchet effect? At first glance, the application of Higgs's ratchet theory to Japan is somewhat problematic, as Article 9 of Japan's "Peace" constitution renounces "war as a sovereign right of the 


\section{Sumner La Croix and Akihiko Kawaura}

nation and the threat or use of force as means of settling international disputes." While Japan maintains "self-defense" forces and has sent military personnel to peace-keeping operations in Cambodia, Rwanda, Afghanistan, and Iraq, it has not been explicitly involved in any wars since World War II.

A closer look shows, however, that the ratchet effect may have some application to Japan. Noguchi $(1995,1998)$ and Okazaki and OkunoFujiwara (1999) have emphasized the persistence of the wartime institutions put in place to mobilize domestic resources for war production. Noguchi catalogued the reasons for the survival of the "1940 System" into the 1990s as well as the problems caused by its persistence. ${ }^{4}$ Among the wartime changes which had a long postwar life were limitations on dividend payments by corporations; the extensive system of subcontracting used by manufacturing firms; the rise of major corporations; tax reforms designed to increase national government revenues; subsidies to rural prefectures; and the consolidation of powers within the national government. With the end of World War II and the ensuing American occupation of Japan, it appeared as if the rachet effect was in full operation, as the American occupiers orchestrated the writing and adoption of a new Japanese constitution, dissolved the zaibatsu (Japan's large, highly-integrated conglomerates), purged some members of the bureaucracy directly associated with the war, instituted new labor and education laws, and implemented extensive agricultural land reform. The American program to dismantle wartime institutions was interrupted by the outbreak of the Korean War in June 1950. When Japan regained its sovereignty in September 1951, many of the wartime institutions were still in place. For example, the 1942 law providing the institutional foundations of the Bank of Japan was modeled after the German Reichsbank law of 1939. Both were designed to mobilize resources for the national government in wartime. The Diet left the Central Bank law intact until 1990.

\section{Institutional schlerosis}

Mancur Olson (1982) in his classic treatise, The Rise and Decline of Nations, argued that established interest groups typically become more powerful over time. They learn how to reward individuals who cooperate with the interest group and punish those who defect. When economic conditions change, thereby increasing potential gains for a new coalition, the old coalition frequently persists in its position because of its superior organizing abilities and the relatively poor organizing abilities of "new" competing interest groups. The increasingly long and strong protection for (outdated) established interests means that productivity growth would decline over time. If, however, a shock eliminates or disrupts the coalition of established interest groups, then government action would be less likely 
to disrupt productivity-enhancing changes by the private sector. Olson used the severe disruptions of World War II on German and Japanese civil society to illustrate his point, arguing that the special interest groups took considerable time to reorganize and become effective, particularly in light of the new governance institutions established by the postwar constitution. As evidence he observed that Japan's economy not only caught up to its previous growth path but greatly surpassed previous growth rates for another 25 years.

Mancur Olson's explanation for the high postwar economic growth in Japan essentially combines the effects of the severe disruption of Japanese civil society with the persistence of wartime institutions for resource mobilization. The argument is that the disruption of civil society in Japan left space for nationalistic bureaucrats to implement policies designed to reconstruct the economy without significant opposition from losing organizations. ${ }^{5}$ As old and new interest groups began to organize more effectively, they gradually gained more influence and, Olson presciently argued, would ultimately produce less institutional change and lower rates of economic growth. His analysis, conducted in the late 1970s and early 1980s, represents a remarkably accurate forecast of the "lost decade" of the 1990s.

\section{Developmental state}

Olson's explanation is somewhat agnostic as to whether the high economic growth in Japan emerged because the disruptions in civil society allowed effective market adjustments to changes in relative prices and endowments of technology, human capital, and physical capital or whether the disruptions allowed for bureaucrats to redesign and implement policies and institutions that facilitated the society's adjustments to the rapid structural changes. Among many political scientists, the emerging conventional wisdom for Japan's spectacular growth and subsequent slow-down is that Japan experienced difficulties in transiting between institutions that facilitate rapid catch-up growth by encouraging technology transfer and capital accumulation and those that facilitate growth once the frontier of production and organizational technology has been reached by encouraging development of new technologies (Hayami 1998; Hayami and Ogasawara 1999). In these scenarios, Japan used command-and-control style regulation to facilitate resource allocation to industries that could imitate and improve frontier technologies and thereby compete on world export markets (Johnson 1982; Hayami 1996). ${ }^{6}$

These theories suffer from the presumption that the developmental state has been a highly effective institution in Japan - a notion that David Weinstein's work has gravely undermined. Weinstein analyzed the effects of providing industries with special privileges: trade protection, subsidies, special corporate tax breaks, and government loans. His econometric 


\section{Sumner La Croix and Akihiko Kawaura}

analysis found that not only was there no systematic distribution of these privileges, but that industries receiving them typically grew slower than other industries. Weinstein and Beason $(1995,85)$ concluded that "Japanese industrial policy very like its French and American counterparts over the past four decades [has been] politically driven, favor-based, nonhelpful to the nation's overall functioning." If the developmental state has been ineffective, then stagnation may have been the result of growing deadweight losses ensuing from its ineffective industrial policies; as the economy becomes more complex and more integrated with a rapidly changing global economy, the losses from misplaced regulations are likely to become larger.

There was, however, more to the apparatus of the developmental state in Japan than just the provision of special privileges to targeted industries. The institutions and organizations put in place in the 1930s and early 1940s to direct resources to the war machine were also used by the Japanese government to mobilize resources for the reconstruction and modernization of Japan's infrastructure (highways, ports, railways, airports, power, telecommunications, and water) and housing stock for three decades following World War II. While it is still an open question as to how well the channeling of savings from the Postal Savings Bank to the quasi-public FILP (Fiscal Investment and Loan Program) corporations facilitated the rebuilding of infrastructure, bureaucrats and politicians increasingly realized, particularly after the second oil price shock (1978-81), that a program of privatization and deregulation was necessary both to bring the government budget back into balance and to promote economic growth. A program of privatization and deregulation had considerable success in some sectors but left government ownership and regulation in other sectors relatively untouched (La Croix and Mak, 2001).

A number of recent researchers (including contributors to Blomström et al. 2003; and Cargill and Yoshino 2001) have bypassed the question of whether the extensive government involvement in infrastructure provision and the financial system was effective and have instead focused on measuring the burdens which these institutional arrangements currently impose on the economy. Particular attention has been paid to constructing estimates of the financial positions of private and public financial organizations, semi-public corporations, and - including the Postal Saving Bank - the largest public and private banks and insurance companies, the semipublic FILP corporations, and prefectural and local governments. Careful estimates of the on- and off-book debts accumulated by these organizations - summarized concisely in Hoshi and Kashyap (2004) - provide overwhelming factual support to reform efforts to stem future losses and to address the untenable debt burdens accumulated. These contributions oscillate between the public choice tradition - in which bureaucrats following their own interest bring about inefficient arrangements - and the constrained efficiency tradition, in which institutional change is moving as fast 
as it can, given the constraints on choices by elected representatives and bureaucrats.

\section{Liberal Democratic Party legislators: in control or bureaucratic} puppets?

Japanese institutions are surely the product of the electoral system and the interactions between legislators, bureaucrats, and their constituents. Japan's multi-member electoral districts and the dominance of Japan's "umbrella" political party, the Liberal Democratic Party (LDP), have been at the center stage of most analyses of the electoral system. Mark Ramseyer and Frances Rosenbluth (1993) argued that Japan's multimember districts have forced the LDP to offer multiple candidates in each district, with politicians focusing on votes from specific interest groups. The factional organization of the LDP provides a decentralized mechanism for identifying relevant interest groups and developing innovative policies to serve them. These "particularistic" Diet members then have strong incentives to reward their interest groups with desired regulatory policies. Ramseyer and Rosenbluth argued that as the Japanese polity changed, the LDP regularly changed its organization and policy stances to remain in power.

A 1993 electoral reform eliminated the multi-member districts, replacing them with 300 single-member districts and 200 representatives elected from proportional lists in 11 different-sized districts with 7-33 representatives elected per district. The new electoral system provides incentives for smaller parties to merge or cooperate to field single candidates against LDP candidates in the single-member districts, but also provides incentives for small parties to remain independent due to their prospects for gaining Diet seats via the proportional representation list. Over the last decade, support for the LDP has fallen - as one might expect given Japan's stagnant economic performance - and it has been forced into coalitions with smaller parties to stay in power. Opposition to the LDP remained relatively fragmented through 2004, with grand opposition ventures such as the defunct New Frontier Party achieving little success. The consolidation of the opposition around the Democratic Party of Japan in the 2004 elections has, however, continued into 2006 in spite of the overwhelming LDP victory in the 2005 elections.

Throughout, Ramseyer and Rosenbluth take the controversial view that the relationship between Japanese bureaucrats and LDP bureaucrats is best analyzed as a well-functioning principal-agent relationship in which bureaucrat agents effectively carry out policies desired by LDP Diet members - the principals - which are designed to keep them in power. This constrained efficiency approach differs greatly from the one chosen by Gerald Curtis (1999) and many other commentators. They hold that bureaucrats have a great deal of independent authority, some informational advantages, and 
are not always well monitored by Diet members. In this world, bureaucrats are an independent force to be reckoned with, and political maneuvering among politicians and factions also helps to determine the outcome.

\section{Institutional change in Japan: the lost decade and its aftermath}

\section{Determinants of institutional change}

In North's framework (2005), the interaction between institutions and organizations is a critical determinant of institutional change. Individuals and organizations compete to take advantage of opportunities presented under the given institutional structure. If organizations perceive that they have better opportunities under a different set of rules, then they will devote resources to changing rules if they perceive reasonable possibilities of success. North $(2005,59-61)$ argues that vigorous competition among organizations is likely to lead to rapid institutional change, while muted competition will lead to a more stable institutional environment. In this competitive environment, organizational survival depends on making productive innovations or being able to adapt well to changes in the environment, e.g. changes in relative prices. For an organization to engage in either innovation or adaptation, the individuals associated with the organization must invest in skills and knowledge. Investment in human capital depends heavily on the incentives posed by the society's institutions, and the type of human capital acquired shapes individuals' belief structures and their perceptions of the opportunities presented by the society.

Some institutional changes will occur in a Hayekian fashion, as the combination of investment in knowledge and competition among individuals and organizations alters the informal norms which serve as the primary constraints on individual behavior in many situations. Hiroshi Ono's analysis of marriage in Japan (ch. 9 this volume) relies heavily upon changes in informal norms as the economic environment rapidly changed in post-World War II Japan. Other changes in the institution of marriage were, however, effected by changes in the legal environment concerning divorce and care of elderly parents. With respect to institutional changes which require assent by the polity, individuals typically need to understand how the environment has changed, thereby increasing the gains from adopting alternative institutions; they need to perceive that superior, alternative institutions exist; they need to understand how the new institutional arrangements will affect their welfare; and there need to be incentives for political entrepreneurs to act to overcome free-riding problems. Most importantly, in most cases there will be organizations and individuals that will lose from the changes, and in some instances they will have incentives to engage in action to stop change or to push for alternatives which are less beneficial for the overall society. Because political institutions are 
not and cannot be organized as markets, there is no guarantee that the political process will generate efficient institutional change.

North places special emphasis on how "economies of scope, complementarities, and network externalities of an institutional matrix make institutional change overwhelmingly incremental and path dependent" (North 2005, 5). Change will usually be incremental (and therefore slow) because "large-scale change will create too many opponents among existing organizations that will be harmed and therefore oppose such change." Path dependence occurs "because the direction of the incremental institutional change will be broadly consistent with the existing institutional matrix ... and will be governed by the kinds of knowledge and skills that that the entrepreneurs and members of organizations have invested in" (North 2005, 62).

North and Weingast (1989) and Gary Libecap (1989) have emphasized that those in power will change institutional arrangements to secure their own wealth rather than the wealth of the overall society. For example, Greif et al. (1994) constructed a repeated-game model to analyze the emergence of merchant guilds during the late medieval period in Europe. They argued that merchant guilds were a mechanism to secure merchants' property rights in foreign cities and were, therefore, an institution that extended rather than restricted trade. In their view the guild "functioned as a nexus of contracts, weaving separate agreements with the individual merchants and the cities in which its members traded into a system whose parts were mutually supporting" (p. 772). With the rise of the centralized nation-state in Europe, political entities began to assume the functions previously carried out by the merchant guilds. Greif et al. observed that the merchant guilds did not fade away (as an efficiency theory of group selection would dictate), but instead "some guilds became fiscal instruments that hindered trade expansion in the emerging states. Other guilds consolidated their political power and, after securing their members' rights, turned to limit the rights of their competitors" (p. 773). Thus, rather than change their internal institutions to better facilitate exchange in the new contracting environment, guilds chose instead to use this machinery to raise rivals' costs of facilitating exchange.

Greif's study (1994) of two differently organized pre-modern societies the Maghribi traders of the eleventh century Muslim world and the Genoese traders of the twelfth century Latin world - carefully examined how two different groups of merchants adapted to changes in the contracting environment. Greif observed that the two groups faced similar contracting environments, yet chose very different societal organizations to support long-distance exchange of merchant goods. The Maghribi traders formed an insider trading group with a structure closely resembling the stylized model for trading groups outlined in Yarbrough and Yarbrough (1999) and Landa (1994). Their common social and religious ties enabled them to support the requisite institutions for information exchange and 


\section{Sumner La Croix and Akihiko Kawaura}

collective punishment. By contrast, the Genoese traders were more individualistic. They did not share information among themselves, did not restrict certain trading networks to other Genoese, and relied on state enforcement of contracts rather than collective punishment by the group of Genoese traders.

Greif's game-theoretic analysis of the two societies came to a striking result: The use of insider groups to facilitate exchange is more efficient in supporting intra-economy trade but is less efficient than a system of contract law in supporting inter-economy trade. As trade expands and the size of the market increases, inter-economy trade becomes more lucrative and the gains from switching from insider groups to the impersonal system of contract law increase. Thus, insider groups have advantages when they function relatively autonomously but encounter problems when they have to contract with other groups. While the historical record is insufficient to compare the relative efficiency of the Genoese and Maghribi traders, it is notable that in the long run Italian traders thrived and the Maghribi traders disappeared from the Mediterranean trading world. Potential applications to modern Japan arise from the perception that Japan's unique institutions are more suited to intra-economy than inter-economy trade. If globalization requires that Japan standardize its institutions with the rest of the world, both import- and export-competing businesses will suffer until institutional changes have been completed.

\section{Institutional change in Japan}

\section{Incremental reform}

The premise that the Japanese government has done nothing to reform its economy over the last two decades is just plain wrong. To name just a few prominent examples:

- Japan engaged in a wave of privatization in the mid-1980s, privatizing its national railroad (JNR) in 1987, its flagship air carrier (JAL) in 1985, and its telephone carrier (NTT) in 1985.

- During the 1990s, major deregulation initiatives were undertaken in the trucking, airlines, taxi, telecommunications, and electricity industries.

- In 1997 Japan repealed its Large-Scale Retail Store Law, returning limited regulatory powers over construction of large retail stores to provincial and local governments.

- The "Big Bang" financial reforms, implemented between 1998 and 2001, were just the latest steps in a long string of deregulatory measures in finance and banking. ${ }^{7}$

- In April 2001, there was a reform of the Fiscal Investment and Loan Program (FILP), which channels funds from the Postal Savings Bank 
to public corporations and local governments. ${ }^{8}$ FILP corporations are forced to raise funds directly from financial markets; their bonds are not guaranteed by the national government; and the Postal Savings Bank does not have to purchase FILP bonds.

- In 2004, the Post Office was corporatized, and in 2005 the Diet approved its privatization.

Despite these changes, it is important also to analyze the view that change in Japan has been slow.

\section{Japan has a tradition of slow change}

One should not conclude from Japan's recent performance that it is incapable of carrying out necessary institutional reforms. Change is a tradition in Japan. The historical record since Commodore Mathew Perry's black ships first appeared in Yokohama Bay serves as a vivid reminder that Japan has constantly changed over the last 150 years. ${ }^{9}$ The successful borrowing and transplantation of foreign political and economic institutions during the 1870 s and 1880 s serves as a reminder of Japanese willingness to borrow organizational as well as production technology from overseas and to adapt them to Japanese circumstances. Japan's slow response to its depressed economy also has precedents in its own modern history. During two long periods, 1895-1914 and 1919-32, Japanese per capita income growth rates averaged less than 0.6 percent, slow growth rates for a developing country. Both long periods of stagnation were, however, followed by robust economic growth, albeit in wartime environments (Weinstein 2001).

Institutional change carried out during the post-World War II occupation and embedded in the postwar constitution quickly became part of the fabric of Japanese life. Labor unrest during the 1950s gave way to new labor market institutions, including lifetime employment. As in Italy, parliamentary democracy coalesced around one party - the LDP - and lively policy debates ensued inside the LDP. Unwanted institutional change imposed during the postwar occupation was quickly reversed, the most prominent example being the re-centralization of education in the national government.

Japan's ability to engage in structural reform during its four decades of high growth after World War II has been a central feature of its economy. From initial specialization in coal, silk and cotton textiles, processed foods, and toys came the transition in the 1970s and 1980s to cars, electronics, steel, and semiconductors. Today's critical question is whether Japan can make the next shift to finance, insurance, computer software, and telecommunications. ${ }^{10}$ Studies of productivity in these sectors during the 1990s show them lagging far behind the United States. Yet institutional change that facilitates adoption of the latest organizational technologies by 


\section{Sumner La Croix and Akihiko Kawaura}

Japanese firms could push these industries to the forefront and produce a sustained phase of economic growth.

\section{Japan is not unique in its slow response to crisis}

The widespread assertion that Japan's decade-long economic crisis is unprecedented among industrialized countries in the post-World War II period is false. Timothy Kehoe and Edward Prescott (2002) have studied economic depressions in both developing and developed countries and have established a useful benchmark for categorizing depressions. They defined an economy as in depression if there is a time period when output per working-age person falls 20 percent below the trend growth path and at least 15 percent of that decline occurs over a ten-year period. ${ }^{11}$ Japan's current economic crisis fits the Kehoe-Prescott criteria for a depression as, over the 1991-2001 period, the gap between actual and trend output was approximately 20 percent.

Kehoe and Prescott also found that two other industrialized countries have experienced depressions since World War II: Switzerland (1973-2000; 30 percent drop) and New Zealand (1974-92; 32 percent drop). At the start of their crises, both countries had high per capita incomes, long experience with market institutions, and rich traditions of democracy. Both countries were also slow to initiate major economic reforms. New Zealand did not embark on major reforms until 1984 - ten years into its depression. The impact of New Zealand's microeconomic reforms was dampened by a poorly designed monetary policy, and their implementation took well over a decade. ${ }^{12}$ The New Zealand change in policy was precipitated by a balance of payments crisis and by a radical change in the policy stance of the Labor Party. Swiss policymakers reacted even slower than in New Zealand, waiting almost two decades to mount major policy responses to their economic stagnation. The slow Swiss response may have been due to Switzerland's high per capita income; its ability to expel guest workers during times of crisis; and the difficulty in gaining consensus in such a linguistically and culturally heterogeneous nation. ${ }^{13}$ Given New Zealand's and Switzerland's slow responses to their depressions, Japan's response appears more typical - the usual case rather than the outlier.

\section{Reform in rich countries}

Why do rich countries in depression wait so long to undertake reforms? One obvious reason is that their wealth and high per capita income provide individuals and firms with a hedge against hard times. This means that prolonged economic stagnation is less likely to cause a precipitous crisis that could force policymakers to undertake major reforms. With its high household savings rates and high incomes, Japan fits this model well. 
The absence of a major crisis in the 1990s that could have forced reform was a major factor in turning stagnation into depression. ${ }^{14}$

New Zealand, by contrast, was forced by an exchange rate crisis to begin implementing reforms in 1984. Blomström (2002) has argued that Sweden implemented swift reforms to its banking system in 1992 due to an exchange rate crisis and a desire to meet the conditions necessary for entry to the European Union. Japan has not faced such a crisis, as it has run balance of trade surpluses throughout the 1980s and 1990s. ${ }^{15}$

A second reason is that by their very nature institutions cannot be too pliant. Institutions are a set of shared expectations about how individuals interact in a society, i.e. the shared perceptions of the rules of the game. Japan has grown rich because its institutions functioned well, and individuals will resist changing them until enough pressure arises to force change.

A third reason is that most rich countries became rich because their governments had ongoing commitments to economic reform. Thus, when stagnation appears, policymakers reasonably believe that they are already undertaking extensive reform measures. They view most downturns as the product of unexpected, temporary, negative shocks - such as higher oil prices - and believe their impact can be minimized with timely, expansionary monetary and fiscal policies. In this environment, policymakers are unlikely to initiate extensive reform programs.

The above explanations fit well Japan's experience with its first two periods of economic stagnation after growth resumed in the early 1950s the first (1973-75) and second (1979-81) OPEC oil shocks. During both episodes, the Japanese government used expansionary monetary and fiscal policies to stimulate the economy after higher oil prices had reduced growth rates. ${ }^{16}$ Equally important, when growth resumed in the early 1980s, the Japanese government implemented several deregulatory and privatization programs to restore budget balance and adjusted monetary growth to achieve low inflation - critical steps that other industrialized nations often fail to take.

\section{An alternative institutional framework}

Chung Lee (ch. 3 this volume) has argued that the lack of a clear model for current reformers to emulate is one reason why institutional change in Japan has been slow. By contrast, there were numerous competing models of success to choose from when the Meiji Emperor chose to adopt and adapt institutions and organizations from Germany, France, England, and the United States. After World War II, elements of the U.S. model were imposed on top of wartime and prewar institutions, ultimately forging a unique Japanese blend. Today, there are fewer economic models that resonate with the Japanese public. Europe and the United States both struggled with low productivity growth from the mid-1970s to the early 1990s. 


\section{Sumner La Croix and Akihiko Kawaura}

While the internet-bio-tech boom of the mid to late 1990s put the bloom back on the American model, the post-millennium stock market crashes and fragile growth in the United States and the European Union have once again raised the caution signs for Japan's decision-makers.

\section{Deflation and its effects on institutional change}

Since the late 1980s, Japan's use of monetary and fiscal policy has been dismal. Unnecessarily loose monetary policy contributed to Japan's land and stock market price bubbles, while tight monetary policy subsequently helped to burst both bubbles in the early 1990s. Expansionary monetary and fiscal policy helped revive the economy in the mid-1990s, but since 1997 the Bank of Japan has engineered a monetary policy that appears to be expansionary - nominal interest rates were 0.25 percent until 1999 and zero thereafter - but has actually been contractionary in practice. This was because the continuation of price deflation left real (inflation-adjusted) interest rates at relatively high levels. The high real interest rates served to at least partially offset a decade of massive deficit spending by the national government.

Economists are virtually unanimous in their judgment that deflation in Japan must be halted if its economy is to prosper. ${ }^{17}$ Unlike the media, which tends to stress the effects that deflation has on postponing consumption as prices of consumer goods will be lower tomorrow, economists stress that the main channel through which deflation hurts the economy is its negative impact on firm balance sheets. ${ }^{18}$ With nominal interest rates near zero in Japan, deflation raises the burden of firms' debt; increases the likelihood that firms will not be able to service bank loans; and reduces or even eliminates bank profits. The combination of financially weak firms and struggling banks works to reduce the efficiency of investment and impair the ability of the economy to restructure and to respond to new opportunities.

Deflation also works through a second, less-noticed channel: It harms the economy by reducing the demand by existing firms for economic reform. ${ }^{19}$ Consider, for example, the quite far-reaching deregulation of fare and entry restrictions in taxi industries in large cities in Japan. The new environment has presented significant opportunities to low-cost taxi companies, as they can expand their market share and earn higher profits under the new regime. If, however, these efficient taxi companies have found their debt burden increasing due to deflation, banks will perceive them as poor credit risks, access to capital markets will be limited, and the needed expansion of taxi fleets in major cities will remain just a mirage. Low-cost taxi firms may now become opponents rather than supporters of deregulation. Ending deflation is a critical step towards achieving successful economic reform. 


\section{Conclusion}

Are there ways in which the Japanese government can encourage and speed up institutional change? Perhaps. We suggest a few while remaining cognizant of the risks and problems associated with each of these policies and political initiatives.

\section{Reforms, political entrepreneurship, and compensation of losers}

Media and academic analysis of Japan's slow reforms has rightly emphasized the central role of interest group politics in Japan's economic stagnation. There are constant reminders of how organized interest groups in Japan have blocked needed institutional change in the 1990s and are likely to continue to block it over the next decade. Although there is much truth in this perspective, it is too pessimistic. In particular, it ignores the basic insight that good economic reforms provide net benefits to Japan. Some groups gain and others lose from reform, but the gains always outweigh the losses from carefully designed and properly executed reforms. The existence of net gains to society is particularly important for two reasons.

First, net gains mean that the winners have more at stake than the losers in pushing for reform. Since the gains are larger to potential winners than potential losers, these groups should prevail if they can overcome free-riding problems and other organizing costs that impair coordinated political action. While potential winning groups may be poorly organized initially, there are incentives - reaping part of the social gains - for political entrepreneurs to take action to organize them and lobby effectively for institutional changes. The rapid emergence of Prime Minister Koizumi within the LDP is a prime example of such political entrepreneurship. The resurgence of traditional forces within the LDP during Mr. Koizumi's tenure as Prime Minister also shows how difficult it can be to overcome organized interests. Mr. Koizumi's fairly modest success in implementing economic reforms has increased the probability that political entrepreneurs in other political parties, e.g. the Democratic Party of Japan, will have more success. The process of mobilizing potential winning groups has been hampered in Japan due to the late development of consumer and public interest groups to counter well-organized industry associations. Non-profit organizations did not even exist in Japan until a few years ago.

Second, the existence of net gains means that losers can potentially be compensated. Full compensation is expensive and is unnecessary in many situations. Partial compensation of all or some losers or full compensation of a few losers may be sufficient to lessen opposition enough to ensure passage of reforms. There are, of course, several problems associated with compensating losers. First, paying compensation makes the reform package more complex and difficult to understand. Second, the losers may not always be easy to identify, as many reform measures have unintended 


\section{Sumner La Croix and Akihiko Kawaura}

consequences and generate effects of uncertain magnitude. Third, if compensation is only paid to some groups, then voters may perceive the reform process as unfair - a consideration that may be particularly important in equity-conscious Japan. Finally, compensation has costs beyond the payments to losers. If the administrative costs and the deadweight losses from the increase in taxes outweigh the net gains, then compensation which seems feasible in theory will prove impractical as legislation.

Daron Acemoglu and James Robinson (2000) have argued that it may not be economic losers that impede institutional and policy changes, but political losers. Economic losers without political power will not have the ability to impede change. Groups with political power who will not lose the political power when there is institutional change will not have incentives to block the net gains enjoyed by society from the change. However, those who have political power and will lose it if there is institutional change have incentives to block this change. Their analysis could provide some insight into the resistance to change in Japan because of the numerous interest groups assembled under the umbrella of the Liberal Democratic Party (LDP). If institutional change causes economic losses to even a few of these groups and results in the expansion of groups tending to vote for opposition parties, then LDP politicians may be reluctant to move ahead with the changes even if most groups within the LDP gain from the changes. On the other hand, umbrella political parties may also be well equipped to provide compensation to losing groups within the party and thereby keep them from leaving the party.

\section{Trade agreements as vehicles for institutional change}

Japanese manufacturing firms producing high-technology products could reap significant gains if Japanese trade with Pacific Rim countries were to be further liberalized. Since Japan's comparative advantage clearly lies in human and physical capital-intensive industries, trade liberalization would also imply increases in imports from other countries in the region, in particular the Association of Southeast Asian Nations (ASEAN) countries and China. These gains would come at the expense of significant losses to Japanese farmers and manufacturers and workers producing goods intensive in unskilled labor. ${ }^{20}$ The Singapore-Japan Free Trade Agreement (FTA), concluded in January 2002, signals Japanese interest in more

liberal trade, yet was relatively easy to conclude due to Singapore's lack of a significant agricultural sector, its relatively high wage rates, and its small size. A draft of the Japan-Mexico FTA was rejected by Mexico in 2003 due to inadequate consideration provided to agricultural exports from Mexico. Additional concessions to Mexico's agricultural sector allowed the FTA to be concluded in April 2004.

The Japan-Mexico FTA and the recent Japanese interest in negotiating FTAs with ASEAN, South Korea, and China signals that potential Japan- 
ese winners from increased trade, i.e. high-technology Japanese manufacturing firms and their labor force, may finally be organizing more effectively to press their interests within Japan. Liberalized trade with Pacific Rim countries (the participants in Asia Pacific Economic Cooperation [APEC]) would have three major consequences: (1) It would shift the Japanese economy towards its comparative advantage - just the recipe for a long-lived burst of growth; (2) it would reduce pressure on Asian governments to resist yen depreciation, as new markets would open to offset any losses to their existing exporters from yen depreciation; and (3) lower prices on goods produced in highly competitive foreign markets would produce new pressures for additional reform in Japan. The pressure that World Trade Organization membership is exerting on China to reform its inefficient state-owned enterprises could well be replicated in Japan if it were to negotiate a series of substantive FTAs with ASEAN, China, and Korea.

\section{Shrinking the banking system}

Since 2002, the Japanese government has exerted considerable effort to clean up non-performing loans in its banking system. The clean-up of nonperforming loans has been accompanied by a consolidation in the commercial banking sector which has seen the emergence of several very large nationwide banks. The consolidations do little to address one of the major problems of the banking system: widespread excess capacity. Takeo Hoshi and Anil Kashyap (2004) have concluded that the Japanese banking system is about one-third too large, and they cannot see how a small number of large banks will find it easier to downsize than a larger number of smaller banks. If anything, the consolidated banks should find it easier to organize for political action (as free-riding is less of a problem), thereby reducing opportunities for downsizing and productivity improvement in this troubled industry.

\section{Decentralization of government responsibilities}

During the 1930s, Japan centralized its political system, leaving few powers with prefectural governments. The nationally-focused political system persisted with few changes through the mid-1980s when Japan began a series of reforms, ultimately transferring some limited functions of government back to the prefectures. Japan's limited grant of powers to prefectural governments deprives the system of two important features: limited experiments with innovations in government and relative performance evaluation (Besley and Case 2003). ${ }^{21}$ One well-known advantage of a decentralized political system is the ability of one regional government to experiment with an institutional or policy innovation and for other governments to study the results of such innovations. Such regional experiments 


\section{Sumner La Croix and Akihiko Kawaura}

allow a variety of alternatives to be studied before a nationwide policy is chosen; the parallel experiments should generate sufficient information for a better choice of policies by other regional governments. The limited powers granted to Japan's prefectural governments limits the scope of such experiments. A second advantage of a decentralized political system is the ability it provides voters to engage in relative evaluation of institutions and policies. If two neighboring regions are hit with the same shock, then voters in each jurisdiction can examine the relative performance of institutions, policies, and politicians in both jurisdictions. This provides voters with a yardstick by which to measure performance in their jurisdiction. The sharply circumscribed powers granted to prefectural governments in Japan limits this channel of institutional evaluation and change.

\section{Acknowledgments}

We thank James Mak and participants in the 2003 Conference, Institutional Change in Japan: Why It Happens, Why It Doesn't, held in Honolulu, Hawaii for comments on an earlier draft. We also thank Magnus Blomström for extended, stimulating discussions on this topic.

\section{Notes}

1 The Leibowitz and Margolis articles on path dependence are collected in Lewin (2002).

2 Low mortality rates of settlers were often correlated with high mortality rates of the indigenous population.

3 By contrast, Sokoloff and Engerman (2000) argued that the type of crop suitable for cultivation in a particular environment was a major determinant of institutional choice. For example, in environments suitable for wheat, smallholder cultivation was the norm, while in environments suitable for sugar, slave cultivation was the norm.

4 Okazaki and Okuno-Fujiwara (1999) offer a detailed illustration of the historical events that led to the transformation of the Japanese economy away from the orthodox capitalist, market-oriented system that existed until the mid1930s.

5 Edward Lincoln's book, Arthritic Japan (2001) and Richard Katz's two books, Japan: The System that Soured (1998) and Japanese Phoenix: The Long Road to Economic Revival (2003), are in this Olsonian tradition.

6 T.J. Pempel's 1998 book, Regime Shift, offers an explanation based on the political dominance of the LDP through the 1970s. The lack of political competition enabled the party to implement economically rational policies that allowed for broad-based economic growth. With the rise of multiple political parties and the decline of the LDP, he argues that policymaking became more politicized. In many ways, Pempel's explanation of Japanese growth and stagnation is Olsonian in its basic outlines, with political parties added as intermediary organizations. See also an intriguing book by Bai Gao (2001) which emphasizes how strategic political decisions led to economic growth in the 1951-73 period but also created later problems of path dependence.

7 See Hoshi and Kashyap (2001) for a magisterial discussion of the evolution of the Japanese banking and financial system. 
8 See Doi and Hoshi (2003) for a full discussion of FILP reforms.

9 See Weinstein (2001) for an excellent discussion of Japan's experience with stagnation and reform.

10 Weinstein $(2001,37)$.

11 Kehoe and Prescott (2002) adopt an annual per capita growth rate of 2 percent as the trend growth path for all countries in their study.

12 See Evans et al. (1996) for an extensive analysis of New Zealand's reforms.

13 See Organization for Economic Cooperation and Development (2001) for a discussion of Switzerland's economic reforms and ongoing problems.

14 In 1997, there were two major financial crises: the liquidation of Yamaichi Securities (one of the Big Four securities houses) and the collapse of Hokkaido-Takushoku Bank (one of the City Banks that the Ministry of Finance had openly promised to defend). While both crises had the potential to trigger major banking reforms and were accompanied by a yen depreciation, there was never any sense that they were likely to generate a currency crisis or a balance of payments crisis. Japan's high level of international currency reserves made a balance of payment crisis extremely unlikely.

15 Japan ran balance of payment deficits during the Gulf War years.

16 Over-expansive monetary policy prior to the first OPEC oil shock resulted in high inflation rates in 1974. Management by the Bank of Japan of the second OPEC oil shock was considerably better.

17 Japanese economists have cited numerous reasons why monetary policy cannot be made more expansionary without risking serious consequences such as hyper-inflation or severe problems with the central bank balance sheet. Foreign economists have emphasized that there are many additional tools that can be used to increase the money supply without impairing the future viability of the Bank of Japan. See Cargill (2001) for a full discussion.

18 Media discussions have emphasized that deflation provides incentives for consumers to defer consumption to future periods, thereby contributing to a fall in aggregate demand today and a stagnating economy.

19 See Kroszner and Strahan (1999) for an analysis of factors driving banking deregulation in the United States.

20 Increased imports in these sectors could induce Japanese firms to improve their productivity. See Weinstein $(2001,39)$.

21 We abstract from the well-known sorting result - when consumers are mobile and heterogeneous, endogenous policies will arise across jurisdictions to cater to the heterogeneous preferences.

\section{Bibliography}

Abe, Y. (1994). "Specific Capital, Adverse Selection, and Turnover: A Comparison of the United States and Japan," Journal of the Japanese and International Economies 8, 272-92.

Acemoglu, Daron and James A. Robinson (2000). "Political Losers as a Barrier to Economic Development," American Economic Review 90(2), May, 126-30.

Acemoglu, Daron, Simon Johnson, and James A. Robinson (2001). "The Colonial Origins of Comparative (Econ) Development: An Empirical Investigation," American Economic Review 91(5), December, 1369-401.

Aoki, Masahiko (1994). "The Contingent Governance of Teams: Analysis of Institutional Complementarity," International Economic Review 35(3), August, 657-76.

Aoki, Masahiko (1996). "Towards a Comparative Institutional Analysis: Motivations and some Tentative Theorizing," Japanese Economic Review 47(1), March, 1-19. 
40 Sumner La Croix and Akihiko Kawaura

Aoki, Masahiko (2001). Toward a Comparative Institutional Analysis. Cambridge, MA and London: MIT Press.

Aoki, Masahiko, Hugh Patrick, and Paul Sheard (1994). "The Japanese Main Bank System: An Introductory Overview," in Masahiko Aoki and Hugh Patrick, eds, The Japanese Main Bank System: Its Relevance for Developing and Transforming Economies. Oxford: Clarendon Press.

Ariga, Ken and Yasushi Ohkusa (1997). "Kigyo shisan-no chikuseki-to nihon-teki koyo shisutemu" [Corporate Asset Accumulation and the Japanese Employment System], in Kazumi Asako, Shin-ichi Fukuda, and Naoyuki Yoshino, eds, Gendai Makuro Keizai Bunseki [Modern Macroeconomic Analysis]. Tokyo: Tokyo University Press, 123-53 (in Japanese).

Barzel, Yoram (1997). Economic Analysis of Property Rights. 2nd edn. New York: Cambridge University Press.

Becker, Gary S. (1983). "A Theory of Competition Among Pressure Groups for Political Influence," Quarterly Journal of Economics 98, August, 371-400.

Besley, Timothy and Anne Case (2003). "Political Institutions and Policy Choice," Journal of Economic Literature 41, March, 7-73.

Blomström, Magnus (2002). "What Can Japan Learn from the Swedish Crisis in the 1990s?" in Fixing Japan's Economy. Washington, D.C.: Japan Information Access Project.

Blomström, Magnus, Jennifer Corbett, Fumio Hayashi, and Anil Kashyap, eds (2003). Structural Impediments to Growth in Japan. Chicago, IL: University of Chicago Press.

Buchanan, James M. and Gordon Tullock (1962). The Calculus of Consent: The Logic of Constitutional Democracy. Ann Arbor, MI: University of Michigan Press.

Cargill, Thomas (2001). "Monetary Policy, Deflation, and Economic History: Lessons for the Bank of Japan," Monetary and Economic Studies 19 (S-1), February, $113-42$.

Cargill, Thomas F. and Naoyuki Yoshino (2001). The Postal Savings System and the Fiscal Investment and Loan Program in Japan. New York and London: Oxford University Press.

Coase, Ronald (1937). "The Nature of the Firm," Economica 4(16), November, 386-405.

Coase, Ronald (1960). "The Problem of Social Cost," The Journal of Law \& Economics 3(1), 1-44.

Curtis, Gerald (1999). The Logic of Japanese Politics. New York: Columbia University Press.

David, Paul A. (1985). "Clio and the Economics of QWERTY," American Economic Review 75(2), May, 332-7.

David, Paul A. (1997). "Path Dependence and the Quest for Historical Economics: One More Chorus of the Ballad of QWERTY." Oxford University Discussion Papers in Economic and Social History, No. 20 (November).

Doi, Takero and Takeo Hoshi (2003). "Paying for the FILP," in Magnus Blomström, Jennifer Corbett, Fumio Hayashi, and Anil Kashyap, eds, Structural Impediments to Growth in Japan. Chicago, IL: University of Chicago Press.

Evans, Lewis, Arthur Grimes, and Bryce Wilkinson (1996). "Economic Reform in New Zealand 1984-95: The Pursuit of Efficiency," Journal of Economic Literature 34(4), December, 1856-902.

Fukao, Mitsuhiro (1999). "Nihon-no kinyu-shisutemu fuan-to koporeto gabanansu 
kouzo-no jakuten" [Financial System Crisis and Weakness in the Corporate Governance Structure in Japan], in M. Aoki, M. Okuno-Fujiwara, and T. Okazaki, eds, Shijo-no Yakuwari Kokka-no Yakuwari [The Role of the Market and the Role of the State]. Tokyo: Toyo Keizai Shimposha, 149-88 (in Japanese).

Fukao, Mitsuhiro (2003). "Financial Sector Profitability and Double Gearing," in Magnus Blomström, Jennifer Corbett, Fumio Hayashi, and Anil Kashyap, eds, Structural Impediments to Growth in Japan. Chicago, IL: University of Chicago Press.

Gao, Bai (2001). Japan's Economic Dilemma: The Institutional Origins of Prosperity and Stagnation. New York: Cambridge University Press.

Greaney, Theresa (2001). "Assessing the Impacts of US-Japan Bilateral Trade Agreements, 1980-1995," World Economy 24, 127-57.

Greif, Avner (1994). "Cultural Beliefs and the Organization of Society: A Historical and Theoretical Reflection on Collectivist and Individualist Societies," Journal of Political Economy 102, 912-50.

Greif, Avner, Paul Milgrom, and Barry R. Weingast (1994). "Coordination, Commitment, and Enforcement: The Case of the Merchant Guild," Journal of Political Economy 102, 745-76.

Hayami, Yujiro (1996). "A Commentary on the 'East Asian Miracle': Are There Lessons to be Learned?" Journal of the Japanese and International Economies 10, 318-25.

Hayami, Yujiro (1998). "Toward an East Asian Model of Economic Development," in Yujiro Hayami and Mashiko Aoki, eds, The Institutional Foundations of East Asian Economic Development. Basingstoke: Palgrave Macmillan.

Hayami, Yujiro and Junichi Ogasawara (1999). "Changes in the Sources of Modern Economic Growth: Japan Compared with the United States," Journal of the Japanese and International Economies 13, 1-21.

Hayashi, Fumio and Edward C. Prescott (2002). "The 1990s in Japan: A Lost Decade," Review of Economic Dynamics 5(1), January, 206-35.

Higgs, Robert (1987). Crisis and Leviathan: Critical Episodes in the Growth of American Government. New York: Oxford University Press.

Horiuchi, Akiyoshi and Katsutoshi Shimizu (2001). "Did Amakudari Undermine the Effectiveness of Regulator Monitoring in Japan?" Journal of Banking and Finance, 25(3), March, 573-96.

Hoshi, Takeo and Anil K. Kashyap (2001). Corporate Financing and Governance in Japan: The Road to the Future. Cambridge, MA: MIT Press.

Hoshi, Takeo and Anil K. Kashyap (2004). "Japan's Financial Crisis and Economic Stagnation," Journal of Economic Perspectives 18(1), Winter, 3-26.

Johnson, Chalmers (1982). MITI and the Japanese Miracle. Stanford, CA: Stanford University Press.

Katz, Richard (1998). Japan: The System That Soured - The Rise and Fall of the Japanese Economic Miracle. Armonk, NY: M.E. Sharpe.

Katz, Richard (2003). Japanese Phoenix: The Long Road to Economic Revival. Armonk, NY: M.E. Sharpe.

Kehoe, Timothy J. and Edward C. Prescott (2002). "Great Depressions of the Twentieth Century," Review of Economic Dynamics 5, 1-18.

Knight, Jack and Jean Ensminger (1998). "Conflict over Changing Social Norms: Bargaining, Ideology, and Enforcement," in Mary C. Brinton and Victor Nee, eds, The New Institutionalism in Sociology. New York: Russell Sage Foundation, 105-26. 
Komiya, Ryutaro. (1999). Nihon-no Sangyo-Boueki-no Keizai Bunseki [Economic Analysis of Japan's Industry and Trade]. Tokyo: Toyo Keizai Shimposha (in Japanese).

Kroszner, Randall S. and Philip E. Strahan (1999). "What Drives Deregulation? Economics and Politics of the Relaxation of Bank Branching Restrictions," Quarterly Journal of Economics 114(4), November, 1437-67.

La Croix, Sumner and James Mak (2001). "Regulatory Reform in Japan: The Road Ahead," in Magnus Blomström, Byron Gangnes, and Sumner La Croix, eds, Japan's New Economy: Continuity and Change in the Twenty-First Century. New York: Oxford University Press.

Landa, Janet (1994). Trust, Ethnicity, and Identity: Beyond the New Institutional Economics of Ethnic Trading Networks, Contract Law, and Gift-Exchange. Ann Arbor, MI: University of Michigan Press.

Lewin, Peter, ed. (2002). The Economics of QWERTY: History, Theory, and Policy - Essays by Stan J. Leibowitz and Stephen E. Margolis. New York: New York University Press.

Libecap, Gary (1989). Contracting for Property Rights. New York: Cambridge University Press.

Lincoln, Edward (2001). Arthritic Japan: The Slow Pace of Economic Reform. Washington, D.C.: Brookings Institution Press.

Murakami, Yasusuke (1984). Shin-Chukan Taishu-no Jidai [The Age of the New Middle-Class]. Tokyo: Chuo Koronsha (in Japanese).

Murakami, Yasusuke (1987). "The Japanese Model of Political Economy," in Kozo Yamamura and Yasukuchi Yasuba, eds, The Political Economy of Japan. Vol. 1. The Domestic Transformation. Stanford, CA: Stanford University Press, 33-90.

Nishimura, Kiyohiko and Yuji Nakayama (1997). "Ryutsu-to nihon Keizai" [Logistics and the Japanese Economy], in Kazumi Asako, Shin-ichi Fukuda, and Naoyuki Yoshino, eds, Gendai Makuro Keizai Bunseki [Modern Macroeconomic Analysis]. Tokyo: Tokyo University Press, 273-95 (in Japanese).

Noguchi, Yukio (1995). 1940-nen Taisei [The 1940 System]. Tokyo: Toyo Keizai Shimposha (in Japanese).

Noguchi, Yukio (1998). "Japan Under the Wartime Economy," American Economic Review 108(2), May, 404-7.

North, Douglass C. (1981). Structure and Change in Economic History. New York: Norton.

North, Douglass C. (1990). Institutions, Institutional Change and Economic Performance. Cambridge: Cambridge University Press.

North, Douglass C. (1994). "Economic Performance Through Time," American Economic Review 84(3), June, 359-68.

North, Douglass C. (2005). Understanding the Process of Economic Change. Princeton, NJ: Princeton University Press.

North, Douglass C. and John Joseph Wallis (1986). "Measuring the Transaction Sector in the American Economy," in Stanley Engerman and Robert Gallman, eds, Long Term Factors in American Economic Growth. Studies in Income and Growth, Vol. 51. Chicago, IL: University of Chicago Press.

North, Douglass C. and Barry Weingast (1989). "Constitutions and Commitment: The Evolution of Institutions Governing Public Choice in Seventeenth-Century England," Journal of Economic History 49(4), 803-32. 
Okazaki, Tetsuji (1999). "Sengo nihon-no sangyo seisaku-to seifu soshiki" [Industrial Policy and Government Organizations in Post-World War II Japan], in Masahiko Aoki, Masahiro Okuno-Fujiwara, and Tetsuji Okazaki, eds, Shijo-no Yakuwari Kokka-no Yakuwari [The Role of the Market and the Role of the State]. Tokyo: Toyo Keizai Shimposha, 229-61 (in Japanese).

Okazaki, Tetsuji and Masahiro Okuno-Fujiwara (1999). "Japan's Present-day Economic System and its Historical Origins," in T. Okazaki and M. Okuno-Fujiwara, eds, The Japanese Economic System and its Historical Origin. Oxford: Oxford University Press, 1-37.

Okuno M. (1987). "Monitoring Cost, Agency Relationship, and Equilibrium Modes of Labor Contract," Journal of the Japanese and International Economies $1,147-67$.

Okuno-Fujiwara, Masahiro (1999). "Japan's Present-Day Economic System: Its Structure and Potential for Reform," in Tetsuji Okazaki and Masahiro OkunoFujiwara, eds, The Japanese Economic System and Its Historical Origin, Oxford: Oxford University Press, 266-82.

Olson, Mancur (1982). The Rise and Decline of Nations: Economic Growth, Stagflation, and Social Rigidities. New Haven, CT: Yale University Press.

Organization for Economic Cooperation and Development (2001). Switzerland 1999-2000, OECD Economic Surveys. Paris and Washington: OECD.

Osano, Hiroshi and Toshio Serita (1994). “ 'Main' Bank System, Implicit Contracts and Trust in Deferred Payment Arrangements," in Toshiaki Tachibanaki, ed., Labour Market and Economic Performance: Europe, Japan and the USA. London: Macmillan, 312-46.

Pempel, T.J. (1998). Regime Shift: Comparative Dynamics of the Japanese Political Economy. Cornell Studies in Political Economy. Ithaca, NY, and London: Cornell University Press.

Prendergast, C. (1993). "The Role of Promotion in Inducing Specific Capital Accumulation," Quarterly Journal of Economics 108, 523-34.

Prescott, Edward C. (1982). "Prosperity and Depression," American Economic Review 92(2), May, 1-15.

Ramseyer, J. Mark and Frances McCall Rosenbluth (1993). Japan's Political Marketplace. Cambridge, MA and London: Harvard University Press.

Rowley, Charles, Robert Tollison, and Gordon Tullock, eds (1988). The Political Economy of Rent-Seeking. Boston, MA: Kluwer Academic Publishers.

Shimizu, Katsutoshi and Akiyoshi Horiuchi (1997). "Nihon-no seifuti-netto-to kinyu-shisutemu-no anteisei" [The Safety Net and Financial System Stability in Japan], in Kazumi Asako, Shin-ichi Fukuda, and Naoyuki Yoshino, eds, Gendai Makuro Keizai Bunseki [Modern Macroeconomic Analysis]. Tokyo: Tokyo University Press, 85-121 (in Japanese).

Sokoloff, Kenneth L. and Stanley L. Engerman (2000). "Institutions, Factor Endowments, and Paths of Development in the New World," Journal of Economic Perspectives 14(3), Summer, 217-32.

Stigler, George (1975). The Citizen and the State: Essays on Regulation. Chicago, IL: University of Chicago Press.

Svensson, Lars (2001). "The Zero Bound in an Open-Economy: A Foolproof Way of Escaping from a Liquidity Trap," Monetary and Economic Studies 19(S-1), February, 277-312.

Weinstein, David E. (1995). "Evaluating Administrative Guidance and Cartels in 
44 Sumner La Croix and Akihiko Kawaura

Japan, 1957-1988," Journal of the Japanese and International Economies 9, 200-23.

Weinstein, David E. (2001). "Historical, Structural, and Macroeconomic Perspectives on the Japanese Economic Crisis," in Magnus Blomström, Byron Gangnes, and Sumner La Croix, eds, Japan's New Economy: Continuity and Change in the Twenty-First Century. New York: Oxford University Press.

Weinstein, David E. and Richard Beason (1995). "The MITI Myth: Central Planning Fails in Japan," The American Enterprise 6(4), July/August, 84-6.

Weinstein, David E. and Richard Beason (1996). "Growth, Economies of Scale, and Targeting in Japan (1955-1990)," Review of Economics and Statistics 78, May, 286-95.

Williamson, Oliver E. (1985). The Economic Institutions of Capitalism. New York: Free Press.

Yarbrough, Beth V. and Robert M. Yarbrough (1999). "Governance Structures, Insider Status, and Boundary Maintenance," Journal of Bionomics 1(2), 7-34. 


\title{
2 Institutional change in Meiji Japan Image and reality
}

\author{
Janet Hunter
}

\section{Introduction}

Early in 1868, following a coup at the Imperial Palace in Kyoto, responsibility for the administration of Japan passed to a new regime, formally bringing to an end the rule by the Tokugawa Shogunate that had lasted since the start of the seventeenth century. The youthful Meiji Emperor who headed the new regime presided over an era of unprecedented reform. The decades up to World War I, known as the Meiji period, witnessed a radical transformation of many aspects of Japan's national life. By the time of the Emperor's death in 1912 Japan had defeated both China and Russia in war, was allied on equal terms with Britain, and was fast becoming an important player in international economic affairs. This transformation has often gone down in history as an unmitigated success story, and in contemporary Japan, under significant pressure to achieve substantial structural reform, the image of 'success' offers a potentially powerful exemplar. The purpose of this chapter is to analyse the course of the Meiji reform process in order to see what lessons, if any, it might be able to offer for institutional and organisational reform in Japan at the start of the twenty-first century. It will be shown that the image of rapid, successful planned change is at odds with the reality of what was a complex and difficult process, whose outcomes were unpredictable and success uncertain. Contemporary reform attempts would be better informed by recognising this reality, which might in turn limit unrealistic expectations of what is possible, and lead to a greater acknowledgement of those changes that have occurred.

\section{Institutions and organisations}

Defining exactly what we mean by 'institutional change' is not always easy. Advocates of the need for institutional change in contemporary Japan invariably mean organisational change, a change in the system, although inherent in that call is a recognition of the need to change the way that people think about things, and go about doing them. In much of the 
current literature the terms 'institution' and 'organisation' tend to be used interchangeably, in a way that does indeed accord with the considerable identity between the way that people think and behave, and the way that they structure and organise their activities. History, as Paul David has noted, matters profoundly to the evolution of both organisations and institutions, although it is the institutions that are the 'carriers of history', as the effectiveness of the larger organisation is shaped by factors such as mutually consistent expectations, shared information channels and codes, and collectively recognised constraints (David 1994). It is unlikely to be valid, therefore, for an empirically minded economic historian to seek to divorce the analysis of institutions from the study of the organisations that are their historical manifestation, and which mediate their impact on longer term historical development. Like the problematic attempts to analyse the role of 'culture' in economic development, the historical analysis of institutions and institutional change can only really be undertaken by looking at outcomes.

This chapter embraces this broader understanding of 'institutional change', recognising that institutional and organisational change invariably go hand in hand. It takes as its starting point North's definition of institutions as the formal and informal 'rules of the game in a society or, more formally, the humanly devised constraints that shape human interaction [and] ... structure incentives in human exchange, whether political, social or economic' (North 1990, 3). However, it also aims to explore the formal structures that were shaped by these formal and informal rules, articulated by Johnson as 'formal institutions' (Johnson 1992, 26) or by North and others as 'organisations'. In North's words again, 'organizations and their entrepreneurs engage in purposive activity and in that role are the agents of, and shape the direction of, institutional change' (North 1990, 73).

Identifying the sources of institutional change is not easy. As Mary Douglas has argued, institutions do not think independently, but the process of thinking and the formation of ideas are to a considerable extent dependent on institutions (Douglas 1985). It is apparent, however, that the process of institutional change and adaptation is contingent on a capacity to acquire new knowledge and information, and the making of innovations on the basis of that new knowledge. In that sense change can be associated with a process of 'institutional learning', defined as an economy's capacity 'to learn about, adapt and change' its institutional framework (Johnson 1992, 24). Identifying the sources of organisational change has proved somewhat less elusive. As Fruin has observed, 'organizations can and do learn, from others and from themselves' (Fruin 1992, 63). Through its capacity to 'collect and understand inside and outside information and address problems properly on the basis of acquired knowledge' (Suzuki 2002, 4), an organisation goes beyond being a simple agent of institutional change, taking on a particular evolutionary path dictated in line with its own imperatives. This process of 'organisational learning' lies at the core 
of Eleanor Westney's study of organisational transfer in Meiji Japan (Westney 1987). What is important in both institutional and organisational learning, though, are the human agents of change. Any more concrete analysis of the possibilities or process of change needs to consider who might be the agents of change, why they might seek to bring it about and what might constrain or promote their success.

The experience of institutional and organisational change of Meiji Japan highlights a number of factors of considerable relevance to contemporary debates, but care needs to be taken in drawing any clear analogy across a time span of well over a century. First, as historians of technology emphasise, there are major differences between incremental changes on the same trajectory and a shift to a completely new trajectory. In the nineteenth century Japan, like other nations, was seeking to follow the West in creating a modern material world in which, in Mokyr's words, " "useful" knowledge was indeed used with an aggressiveness and a singlemindedness that no other society had experienced before' (Mokyr 2002, 297). While many would argue in the early twenty-first century that some Japanese organisations or institutions should shift to a new trajectory, it would be unrealistic to expect a trajectory shift on the scale that faced late nineteenth century Japan. While changes in organisational technologies are seen as an imperative, there is little concern over production technologies. Second, innovation and learning are a social process, and the possibilities are conditioned by institutions such as property rights or the norms of distribution (Johnson 1992, 36). In that respect institutions can provide the stability needed for change, impede it, or promote it. Since human behaviour is inherent in institutions and organisations, borrowing them from elsewhere is inherently complicated and difficult. Finally, there is the importance of what has been called the 'institutional cluster', in which 'each new component that is added must be adapted to interlock with elements of the pre-existing structure'. The consequence is a favouring of stasis and incremental change, and a tendency to respond conservatively to dysfunctional aspects in the existing system (David 1994, 215). To put it a different way, 'inertia is a basic feature of institutions' (Johnson 1992, 26). A degree of inertia is perhaps what makes them institutions.

Bearing these caveats in mind, this chapter will focus on three particular aspects of the Meiji experience of particular relevance to the current situation. The first is the extent to which there may have been particular short-run pressures that pushed towards effective institutional change in the late nineteenth to early twentieth centuries. I will show that though the reality of change was difficult, and its trajectory often uncertain, the prospect of immediate as well as long-term gains came together to push for change. It will be argued that while it is widely acknowledged that institutional change in contemporary Japan may deliver gains in the longer run, it may prove more difficult in the absence of equivalent short-run pressures. Indeed, the interests of the long-run beneficiaries of such 
change may be in conflict with those of the interest groups who may have to bear the short-term costs, the distributional coalitions in Olson's terms (Olson 1982, 43-7). The second is the fact that institutional change, which with benefit of hindsight may appear both rapid and effective, may often at the time be perceived as both slow and difficult. This was certainly the case in Meiji Japan. Moreover, the historical record suggests that while organisational change can be relatively abrupt, it is far harder to discern discontinuity in institutions. Ways of doing things and thinking about things rarely change overnight, although sudden shifts in the environment or circumstances can generate relatively rapid institutional change. For the most part institutional change is a continuous, dynamic process, characterised by both continuities and discontinuities. The lesson for the present is that it is only by retaining that understanding of institutional change as a process that the organisational and legislative changes currently proposed for the Japanese economy and polity can be properly embedded in a way that will lead to their being effective. Third, the Meiji experience demonstrates the fluctuating nature of the relationship between government initiatives, legislation and regulation, and institutional and organisational change. We need to ask, for example, how far it lies within the capacity of the law-making authorities to pave the way for institutional change, and how far efforts that are too far out of tune with the force of public opinion and publicly recognised need are doomed to failure or, at best, a lukewarm measure of success. Is institutional redesign, as Cargill suggests in Chapter 5 of this volume, ultimately a matter of will and political leadership, and is that political leadership more important when the long-term gains are widely diffused? We need at the same time to consider how far effective institutions of the kind articulated by North may exist without state involvement, indeed how far such institutions may substitute for a regime that under other circumstances might be articulated through a central authority. This might relate, for example, to institutions promoting contract enforceability of the kind analysed by Greif $(1989,1993)$.

The first half of this chapter gives an overview of institutional change in Meiji Japan, focusing in particular on the role of the central government, often depicted as the key agent in the Meiji transformation. It will be suggested that the reality was in many ways rather different from the 'successful' image that is often portrayed. The second half of the chapter looks in more detail at the process of institutional and organisational change in three areas that are at the heart of current debates in Japan: financial institutions; business enterprises; and the labour market and employment system. Analysis of these three areas shows that in all three cases the process of institutional and organisational change was slow and sporadic. The conclusion offers some tentative observations on the 'lessons' the Meiji period may have for contemporary debates. 


\section{The Meiji transformation: an overview}

It is not difficult to see why an account of the Meiji reforms can often end up as a litany of praise. The scale and breadth of many of the changes that followed the 1868 Restoration seem breathtaking and the results were of enormous consequence, for Japan and for the world. Few predicted in 1868 the extent of the changes that would take place. The regime that established control of Japan, after a brief civil war, was dominated by men from leading domains hostile to the Tokugawa, in particular the domains of Satsuma and Chōshū. Their main initial concern was to consolidate their control on power under the figurehead of the Emperor. An Imperial Government was established in the old Tokugawa capital of Edo, now renamed Tokyo, and the old institutions of Tokugawa rule were dismantled. The semi-autonomous domains that had held local control were persuaded to give up their rights, and a new system of local government through prefectures was established. Unlike its Tokugawa predecessors, the new regime established its right to nationwide revenue raising, undertaking a comprehensive land survey as a basis for legal ownership and tax payment responsibilities. The land tax was by far the most important source of government revenue through to the turn of the century.

In dismantling the old domain system, however, the new government was compelled to confront an even more fundamental issue, namely the hereditary caste system that had constituted the foundation of the Tokugawa social system. Under this caste system, the ruling warrior elite (bushi, samurai) had been supported by the labours of the three lower castes, farmers, artisans and merchants. While caste divisions and functions had become blurred and often contradictory by the early nineteenth century, at the time of the Restoration the legal and social foundations of the system remained in force. By abolishing the domains, however, the new government was depriving the elite class of its income, its function (to serve the domain lord), and effectively its status. In a series of measures over the early to mid 1870 s, the old caste system was formally abolished, with the population re-categorised as 'nobility', 'former samurai' and 'commoners'. Samurai were deprived of their traditional right to wear a sword, and eventually of their stipends, receiving instead a lump sum paid in government bonds. By virtue of former elite status and better education, many former samurai continued to dominate the upper echelons of society, but the foundations of the old social system were effectively gone. In their place the regime sought to encourage a new social structure deemed more suited to the 'new' Japan, founded on the primacy of the lineal family (ie) as articulated in the Civil Code of 1898. The patriarchal family system enshrined in the Code remained in force until the 1940s.

To administer the country, an efficient bureaucracy was required, and that, too, had to be created. While former domain administrators and shogunate officials had some relevant experience, systems of training for 


\section{Janet Hunter}

new would-be bureaucrats were developed, and by the early 1890s a rigorous structure for the education and career progression of imperial civil servants had been put in place. In the early years after the Restoration the dividing line between politicians and officials was unclear, but within two decades a clearer division of labour had been established. This division of responsibilities became more important as Japan tentatively moved towards the adoption of a new political system, in which political continuity seemed less guaranteed. For much of the period Japan was ruled by an oligarchy, but over time the numbers of the original group diminished, and by the time of World War I only a small number remained. Recognising the implications of their own mortality, as well as that of their protégés, the oligarchs sought to establish a constitutional system that would guarantee the future stability of the nation, as well as the values in which they believed. A Western-style cabinet system was instituted in 1885, and a new constitution promulgated four years later. The first general election, based on limited male suffrage, was held in 1890. This 'Emperor-given' constitution, which remained in place until 1945, was premised on the inviolable sovereignty of the Emperor, who wielded supreme political power. Below him, and responsible to him, were the cabinet, the armed forces and other bodies that could operate independently of each other. The cabinet was not responsible to the new Diet, whose powers were limited. The constitution has been criticised for legitimating the wielding of national political influence by non-legislative bodies, such as the armed forces and the bureaucracy, but during the Meiji period oligarchic control, though weakening, remained largely intact.

While reforming the apparatus of government was clearly a priority, the extent of Meiji change went far beyond that. Facing the encroachment of Western imperialism, Meiji leaders took the view that Japan's independence could be secured only through the building up of strong military forces to safeguard the national interest, and that in turn meant creating the economic and social basis for military strength. This policy was often referred to as fukoku kyōhei ('rich country, strong army'). By 1877 a new conscript army was strong enough to defeat a major rebellion by disaffected samurai, and within another 30 years Japan's victories over China and Russia had aroused international astonishment. Military production figured prominently in manufacturing growth, and by the time of World War I Japan was capable of producing most of her military needs, up to and including major warships.

Parallel with the growth of the armaments industries, and economically more significant, came major changes in other areas of the economy. These changes related to both production and organisational technologies, and were supported by major changes in infrastructure. Production changes occurred in the agricultural sector, in which technological improvements generated a sustained increase in output, but were particularly conspicuous in the manufacturing sector. While many older forms of 
Institutional change in Meiji Japan 51

handicraft manufacturing persisted, a number of sectors developed factory forms of production, characterised by mechanisation, the use of power and the appearance of an industrial labour force. Light industry dominated factory development at this time, but heavy industry, which required greater investment and skills, was starting to follow by the end of the Meiji period. New organisational technologies, which included institutions such as the joint stock company, impacted substantially on both the manufacturing and commercial sectors. Government was closely involved in this institutional change through the provision of legal, financial and commercial infrastructure, for example the implementation of a commercial code, financial and banking regulations, and a system of central banking and specie-based currency. A new universal compulsory education system was in place from the turn of the century, and a start made on vocational and higher education provision. Supporting physical infrastructure included a comprehensive transport network of roads, railways and coastal shipping.

Building such a capability required not only investment, but general and technical knowledge. Bridging the technological gap between Japan and the industrialised countries of the West became a major objective for both government and non-government interests. It is apparent that, although many of the reforms were essentially internal matters, the West was a powerful model. Moreover, there was a widespread recognition that in order to achieve the repeal of the so-called 'unequal' treaties imposed on Japan by the Western powers in the 1850s, Japan had no choice but to reach Western yardsticks in certain areas of national life. In some areas, therefore, there were systematic programmes to observe Western institutions and practices. Japanese were sent abroad to learn, while foreign experts were invited to Japan to teach. Many Western writings were translated into Japanese. Elsewhere the learning from the West was less systematic, but the ultimate objective of introducing into Japan forms of Western technology, organisation and institutions was the same. However, it would be a mistake to refer to this learning process as 'Westernisation'. While many Western forms were adopted, and while members of the contemporary elite may have thought of themselves as Westernised, Western introductions were not only juxtaposed against an overwhelming body of indigenous practices and norms, but interacted with them. Modification and adaptation to accord to the Japanese environment was the order of the day, and the consequence was new hybrids.

Recent historiography has depicted this process of change as a national project, in which the Japanese population was shaped into Imperial subjects and ideologically conditioned to accept a powerful reinvented Japanese tradition (Gluck 1985; Garon 1997). Ideological dissent was certainly restricted during the Meiji years, and the case for counteracting any external or internal threat by building a strong sense of national unity out of a formerly fragmented entity was an overwhelming one. Moreover, it would be erroneous to argue that the majority of Japanese did not 'buy in' to the 


\section{Janet Hunter}

national project, and the long-standing respect for hierarchy may have made it easier for the elite to demonstrate effective leadership. However, every process of change has winners as well as losers, interest groups to be overruled or won over, and free riders happy to take advantage. This was likely to be particularly true of changes of the magnitude of those outlined above. There was much that was positive about the Meiji transformation, but the process was neither easy nor costless.

\section{The Meiji transformation: image and reality}

European visitors to Japan in the late nineteenth century were often struck by the country's 'backwardness' in relation to the industrialised economies of Western Europe or the United States. Pessimism as to the country's ability to break out of this 'backwardness' was rife. ${ }^{1}$ By contrast, much of the subsequent historiography lauded the rapidity and clarity of a transformation that had established Japan as a regional superpower by the end of the first decade of the twentieth century, and a serious economic competitor to Europe soon after. In particular, the 'modernisation' school of historians focused on internal dynamics as the key to change, and established an image of the historical process of change that has left a lasting influence. Japan benefited, it was claimed, from the external pressures for change that were imposed upon it. The clearsighted political leadership that held power in the wake of the Meiji Restoration of 1868 was not only intent on preserving its own power, but recognised that a failure to bring about substantive change would at best lead to economic and political subservience to the Western powers along the lines experienced by China, and at worst to Japan's becoming subject to colonial status. The overriding imperative behind change was the need first to achieve the ending of the extraterritoriality and unequal treaty system imposed in the $1850 \mathrm{~s}$, and second to build up Japan's political and economic power to bestow equal status with those Western industrial powers. Driven by this stimulus, the members of the ruling elite carefully examined the possible alternatives for change, looking closely at Western institutions and models, and making judicious choices as to what would best suit the Japanese environment. It was recognised that to some extent the process of change built on developments during the Tokugawa period, but the overwhelming emphasis was on the across-the-board institutional transformation, much of it along Western lines. For some scholars and for many contemporaries modernisation was, indeed, Westernisation. Evidence for this view comes in the fact that by the time of World War I Japan possessed not only factories and joint stock companies, but Western-style legal infrastructure, bureaucracy and political structures. While the prevailing 'rules of the game' and the related organisations clearly owed something to the distinctive Japanese environment, they were also sufficiently different from their Tokugawa predecessors to bring an emphasis on discontinuity rather than continuity. 
It would be a mistake to dismiss this assessment of what was by any standards a remarkable period in Japan's history. That Japan almost alone in Asia was able to offer effective resistance to Western imperialism, and to become in her turn an imperialist, testifies to the validity of many of these claims. If we look more closely at this transformation as a process of institutional and organisational change, however, our judgement of 'success' has perforce to be a rather more muted one. We may argue with the benefit of hindsight that on balance the process of institutional change was relatively successful, but that does not mean that it was easy at the time, nor that its success was at all predictable. Research by a number of scholars has demonstrated that institutional and organisational change in the Meiji period was rarely smooth, and in most cases it was several decades before changes became well-established. The early 1870s was devoted in large part to dismantling key elements of the existing system, such as the old domains, the old caste system and the privileges of the samurai caste, including the costly commutation of samurai stipends. Establishing a legal and political framework that was recognised by the Treaty Powers as justifying the repeal of the unequal treaties took around thirty years. New treaties came into force in 1899, but tariff autonomy was not completely regained until 1911. Creating the infrastructure for industrial capitalism took considerably longer. While the basis was in place by the time of the death of the Meiji Emperor, provision still compared unfavourably with that in many European countries or the United States, and was often criticised by Westerners as unreliable or inadequate. Even limited change may have been a remarkable achievement, but many areas of Japanese life were relatively untouched even by 1914. In that year the majority of Japanese still consumed similar food to that eaten in 1868, wore similar clothes, and ran their family businesses very much as they had done earlier. Continuity in lifestyles was supported by social practices and institutions, and these changed only slowly at the local level.

Along the way there was a significant process of trial and error. The Japanese leadership was often divided. While there is no doubt that the external threat was often a compelling factor in the imposition of unity, and the revision of the unequal treaties a common objective, there was far less agreement on how to achieve this ultimate goal. Friction and disagreements were common, and the political history of the Meiji period is characterised by the presence of a number of disenchanted former government members whose views could no longer be accommodated within the decision-making process. Divisions over foreign policy and the pace of reform split the leadership as early as 1873. One disaffected member of the oligarchy, Saigō Takamori, led an armed rebellion in 1877, while others sought to further their opposition through political organisation. A second major rift occurred in 1881 over the direction of constitutional reform.

Nor was the process of change the consequence of a clearly thought through line of action. The extent of information and knowledge 


\section{Janet Hunter}

possessed by all those involved in the process of change was limited, and decision-making at all levels, from central government down, was undertaken on a pragmatic, day-to-day basis. Some of the institutions and organisations adopted can be seen as failures, and were subsequently replaced by others that proved more successful. Banking, which will be discussed below, was only one example of this. The first Criminal Code of 1880, based on the Code Napoléon, was later modified extensively to bring it closer to German statute, while the political-administrative system went through several manifestations before achieving a more settled state with the implementation of the cabinet system and constitution after 1885 .

Overall, the transformation during the Meiji period was essentially a partial one. While there were some conspicuously dramatic changes, large areas of national life remained relatively untouched. Elsewhere the changes were much more subtle and much longer term, becoming obvious only at a much later date. This was in substantial part due to physical and psychological constraints on what was possible, but also to the complex interaction between indigenous and imported institutions in the borrowing process. Many Tokugawa institutions and organisations possessed a considerable degree of sophistication. The level of national market integration was already considerable, and in most areas monetisation and commercialisation were facts of life. While peasants paid rice tribute in kind, most crops other than rice were sold for cash. The ruling warrior class measured its income in rice, but had to convert much of this income into cash for all other purchases, generating significant brokering business. The concentration of the elite away from the countryside led to extensive urbanisation, conspicuous consumption and an increasingly wealthy commercial class. Economic actors had become accustomed to the forms of regulation and practices that had accompanied market penetration, which were invariably distinct from their Western counterparts.

This sophistication of indigenous institutions could be both beneficial and disadvantageous for institutional change. On the one hand, it could lay the foundations for further evolution and development. A peasant farmer accustomed to the use of money and to paying tribute in the form of rice to the domain lord might find the post-Restoration transition to an obligation to pay rent in kind to a landlord or money tax to the state relatively easy. A commercial elite that dealt in futures and had developed advanced accounting practices would not find Western commercial practices totally unfamiliar. In other respects, though, complex and wellestablished indigenous patterns of behaviour and operation might come into conflict with Western alternatives. An emphasis on consensus, collectivity and mutual obligation was potentially antagonistic to any emphasis on self-centred individualism. As Weber had suggested (Weber 1963), East Asian societies influenced by the Confucian ethic judged behaviour with reference to discharging an expected role in society, and not with reference to some extraneous, universal yardstick laid down by an all- 
powerful deity. Such conflicts had to be tackled by compromise, pragmatism and rhetoric. The analysis of particular areas of national life in the second half of this chapter will make this very clear.

\section{The Meiji government and institutional change}

Given the significance of human agents of change in any institutional transformation, the Meiji government has, not surprisingly, been the focus of much analysis. Any government making a decision that a concerted effort is required to bring about institutional change, and then seeking to implement that decision, is faced with two interrelated tasks. The first is the need to dismantle or modify existing unwanted institutions, removing impediments to industrialisation (Gerschenkron 1962). The second is the establishment and development of new, wanted institutions. The Gerschenkronian paradigm is in many ways appropriate in the case of late nineteenth century Japan. The tension between where the country was and where its leaders wished it to be was obvious. The concept of 'relative backwardness' is an appropriate one for a country in which recognition of an inferior international status became the driving force of national policy, although the policies pursued by the regime did not necessarily accord with those articulated by Gerschenkron. The Meiji regime itself identified the need for state action to redeem the situation, and accepted the overriding responsibility for the achievement of success. ${ }^{2}$

In seeking to engineer change the Meiji regime had the support of history. It was an elite government that could build on a strong tradition of intervention in many areas of national life, and not least in economic activity. National and local authorities in the Tokugawa period had not contented themselves with political dominance and control. They had also engaged in extensive regulation of and intervention in the economy, for example through domain monopolies of production, regulation of guilds, and monitoring of the all-important rice market. While the regulation may not always have been effective, the right to intervene was rarely questioned. Indeed, the ethic of mutual responsibility between ruler and ruled even made such intervention an obligation. Providing the new government could consolidate its political and military control, therefore, its right to direct change would not be fundamentally questioned. However, as noted above, post-Restoration governments were rarely completely united, and while members were brought together by a single overriding objective, it was the choices that were made in relation both to dismantling old institutions and building new ones that were the main sources of conflict. Friction was generated by both processes, and was articulated with particular vehemence in the above-mentioned rebellion of 1877, led by Saigō Takamori. Saigō had pressed for the invasion of Korea in 1873, a proposal that had been overruled by his colleagues. He retreated to his home domain of Satsuma, where he built up a large group of followers, mostly 


\section{Janet Hunter}

disaffected samurai unhappy with the changes that were taking place and anxious to preserve 'traditional' values. The 1877 rebellion, in which the rebels were armed with little more than traditional swords and a martial spirit, was crushed only after several months. Friction was also manifested in the political crisis of 1881, in which Ōkuma Shigenobu, a leading figure in the regime in the 1870s, was ousted from the government along with a number of his supporters. The immediate cause of the crisis was disagreements over the sale of government assets and the desired direction of constitutional development, but a more fundamental factor in the split was personal struggles for political domination.

Broader expressions of dissent came in the form of the popular rights movement, and later the small left-wing movement. The campaign for a constitution was initiated by two dissatisfied former oligarchs as early as 1874 , and by the late 1870s support was coming both from former samurai and from the richer members of the farming community. While the government sought to suppress much of this activity, pressure from the movement was a powerful factor in the eventual announcement in 1881 of a move to constitutional government. Sporadic incidents of violent protest over a range of issues persisted through the 1880s. The tradition of antigovernment protest was continued in the last two decades of the Meiji period by the infant socialist movement, although the heavy hand of government combined with internal splits to weaken such protest further in the decade before World War I. These incidents demonstrate, therefore, that domestic conflict was never far away, and opposition to the process of change came from both within the regime and without, and from both conservative and progressive viewpoints.

At a national level the imperative was clear, however. The only way that treaty revision would be achieved would be to establish in Japan institutions along Western lines that would obtain the confidence of Western powers and their citizens. Extraterritoriality would only be relinquished once Europeans and Americans believed that Japan's legal system would safeguard their rights and welfare at least as well as the one they possessed at home. In such cases, therefore, Japan had no choice but to follow Western practices. Elsewhere there was less compulsion to copy Western practice; any choice to do so was more of a pragmatic response. However, Western practice was never uniform, and the political and economic leadership was faced with often difficult choices between Western alternatives.

While the key criteria for making these choices were what was acceptable to the industrialised countries of the West and the extent to which imported practices could be accommodated to the reality of Meiji Japan, it is difficult to discern any consistent and unifying pattern behind the choices that were made, not least because many choices were delegated down from the top level of the regime, or made by individuals completely outside it. There were high-level delegations with a systematic mandate to 
gather information on Western practices, technology and institutions in general, the most famous of which was the Iwakura Mission of 1872-73. ${ }^{3}$ Other investigative missions had more specific remits. In such cases the agent might be a top-ranking figure such as Itō Hirobumi, charged with drafting the new constitution, or a single junior official, as in the case of Maejima Hisoka, who studied the British postal system. Private enterprises sent employees to study technology, and business and educational practices, while foreign employees in Japan were also key sources of information. As might be expected from these disparate channels, the selection of models or institutions for adoption was eclectic and often fortuitous, and the lack of complete unanimity in government guaranteed the diversity of choice. Mistakes were made, as will be demonstrated below in the case of the financial system.

Moreover, the requirement to borrow from outside practices was associated with a high degree of ambiguity in the minds of Japan's leaders. Ideology was important. Even before the Meiji Restoration intellectuals such as Sakuma Shōzan had come up with the concept of wakon yōsai, literally 'Japanese spirit (ethic) and Western technology'. For many of the Meiji leaders the superiority of Western technology and know-how was indisputable, but that of Western institutions and forms of organisation far more questionable. In as far as Western institutions dictated the power structure of international economic and political relations they would have to accept some accommodation, but there was a considerable reluctance to countenance any wholesale imposition of a completely different institutional set-up, even in the absence of the imperatives of the 'institutional cluster' that was likely to render such a thing impractical.

It should be emphasised, however, that distinguishing between the adoption of Western technologies and knowledge and the adoption of Western institutions was often impossible. The import of Western technologies invariably involved in addition a degree of institutional change. Mechanised methods of production, for example, gave rise to factories and new ways of working, while the introduction of a Western-style postal and telegram system facilitated much more rapid information flow, in turn influencing factors as diverse as family relationships, internal migration patterns and market responses. Moreover, the interaction with the indigenous Japanese environment of organisations imported from outside could, through a process of organisational learning, generate significant deviation both from the original model and from the indigenous one, in the process generating a completely new institutional form (see for example Westney 1987).

The overall process was therefore a complex and difficult one, in which the chances of long-term success were unclear and the leading role of the government often ambiguous. This complex reality will be explored in the remainder of this chapter by looking at the course of institutional and organisational change in three particular areas of the economy that are 


\section{Janet Hunter}

also at the core of debates over institutional and organisational reform in contemporary Japan: financial institutions, business institutions and labour market institutions. They are also areas that demonstrate a spectrum in relation to the ability and willingness of government to bring about institutional and organisational change. It must be accepted that the nature of political institutions is also at the heart of the contemporary debate, but even a brief discussion of political change in Meiji Japan lies beyond the scope of this paper. ${ }^{4}$

\section{Reform of the financial system}

The financial and fiscal systems of the Tokugawa period were characterised by the ability to engage in complex dealings utilising sophisticated financial instruments, but in many respects they were incapable of coping either with the revenue demands of the new government or the requirements of industrial capitalism. A major weakness with the existing set-up was its dependence on the ancien régime. Through the guild system, through the operation of the rice market, and through lending to the governing class, the economic power of the commercial elite was closely associated with the pre-1868 status quo. Already under threat from the fall-out of the opening of Japan to international trade, the financial system came under even greater pressure around the time of the Restoration. Extensive gold exports due to a different gold-silver ratio from that operating outside the country, rapid inflation stimulated by the pressures of export demand, civil war and heavy government expenditure, and a devolved fiscal system that limited the income available to the new central regime were all problems that could only be resolved by dismantling the old political institutions pivotal to the old financial system, and this inevitably took considerable time. The 1870 s were associated with major financial and fiscal problems. Attempts at currency stabilisation proved uncertain and often abortive (Tatemoto 1981).

While it was widely recognised that a new financial system and new kinds of institutions were necessary to stabilise the economy and support Japan's international economic integration, the environment surrounding the first attempts at reform in the 1870s was not obviously conducive to success. Efforts to establish a Western style banking system and achieve currency reform both demonstrate how easy it was to take a misguided decision. As early as 1872 the government sought to facilitate the development of currency-issuing national banks modelled on those of the United States, but the initiative took several years to get off the ground, and even then those national banks that appeared remained highly dependent on government funding. If anything, the national bank system exacerbated inflationary pressures, and in the early 1880 s, as part of a broad deflationary strategy, the whole system was abandoned in favour of a completely different set-up, with a central bank with sole right of note issue. The 
Bank of Japan was established in 1882, and under new banking regulations in 1890 all other banks became ordinary banks. National banks had all disappeared by the turn of the century. The process of achieving a coordinated nationwide banking system that could provide a firm foundation for economic growth and fiscal stability had therefore taken 30 years (Tamaki 1995).

Provision of a stable and internationally accepted currency took equally as long, and was similarly contingent on national political unity. The identified need was for a unitary currency to replace the multiple coins and notes issued by local authorities and the commercial elite for transactions in the Tokugawa period. While the new government from early on issued coins and inconvertible paper currency, it was only from 1872, with the consolidation of central control through the abolition of the old feudal domains, that the new national currency, the yen, was instituted. The yen operated on a de facto silver standard, but, as noted above, inflation remained an ongoing problem. In 1878 came the formal adoption of bimetallism, with silver confirmed as the main medium of circulation, but it was not until the introduction of the stringent policy of deflation in the early 1880s under Finance Minister Matsukata Masayoshi that inflation was brought under control. The establishment of the central bank system was critical to this domestic stabilisation, but more was required to inspire international confidence. The aspirations of the Meiji authorities extended beyond a stable banking system and a stable currency to putting Japan on the gold standard, the internationally recognised 'Good Housekeeping Seal of Approval' (Bordo and Rockoff 1996). The extent to which going on the gold standard was crucial for any inflow of foreign capital into Japan is debatable (see e.g. Sussman and Yafeh 2000), but there is no doubt that for the Japanese the symbolic significance of putting the yen on the gold standard was enormous. Going on gold was perceived as showing that Japan had become a full member of the Western-dominated club (Hunter 2004). Aspirations, however, were not easily translated into reality in a capital-scarce economy. That Japan accumulated sufficient gold reserves to peg the currency to gold in 1897 was in large part due to China's payment of a substantial gold indemnity in the wake of the SinoJapanese War of 1894-95. The achievement of international monetary respectability had also taken around 30 years (Goldsmith 1983).

One other aspect of the development of Japanese banking currently under particular scrutiny is the role of commercial banks as lenders to private enterprise. In some respects this particular role of financial institutions does have Meiji roots. The period witnessed the emergence of a range of financial institutions geared to the provision of scarce capital to the private and public sector. These included the so-called special banks set up by government to achieve specific objectives, such as the Yokohama Specie Bank, set up in 1880 to finance foreign trade, the Hypothec Bank, whose purpose was to make long-term loans to the industrial and 
agricultural sectors, and the Industrial Bank of Japan (Tamaki 1995, 98-103). Their activities were supported by other government financial institutions, such as the Post Office Savings system, and the colonial development banks. Local private banks also appeared which over time played a significant role in lending to local economies, while large commercial banks, often under zaibatsu control, helped to fund associated enterprises. ${ }^{5}$ However, although state and private sector financial institutions of this kind did play a role in Meiji Japan in funding new enterprises, it was a very minor role compared with that which evolved later. While it is clear that post office savings or local banks were effective vehicles for the pooling and mobilisation of small savings, and that the government could be the key to large-scale investment, most capital was raised through personal contacts, informal networks or through the often speculative stock exchanges. Reinvestment of profits and private wealth of individuals and families was the major source of capital. Some 60 per cent of registered companies in 1911 were partnerships (limited and unlimited), as opposed to 40 per cent joint-stock companies. A survey of six major industries in 1897 showed that 77 per cent of capital came from personal and private sources, meaning that less than a quarter came in the form of loans from banks and other institutions (Andō 1975, 73-4). Not until the later interwar years did the big zaibatsu banks really consolidate their role as key players in the financial market, when their financial weight was utilised both to support affiliated enterprises and to bring new firms under the zaibatsu aegis (Ogura 2002).

Unlike currency and banking reform, the emergence of the institutions of capital provision in Meiji Japan was neither a necessary consequence of the unequal treaty system, nor even a requirement of stabilising international economic transactions. It was never a question of making a specific choice between available institutional models. More than anything else the appearance of institutions of this kind was a function of late development, the consequence of a response by both government and the private sector to the constraints imposed by late industrialisation and the desire to achieve rapid economic development. The significance of this imperative was equally important in the development of the institutions of business, which will be discussed in the next section.

\section{Business institutions}

The development of new ways of business organisation and operation during the Meiji period was something in which the central and local authorities had a far more limited involvement. Certainly the Tokugawa regime and domain authorities had been concerned to maintain a degree of control over business activity, but the actual forms of business organisation, as well as the attitude to commercial activity, were dictated by factors such as the technology of production and the prevailing modes of social 
convention and interaction. The social appraisal of commercial activity and profitmaking was a relatively negative one, as members of the merchant class had been designated as the lowest of the four main strata of Tokugawa society. While the commercial elite had in many cases achieved considerable economic power, this was not necessarily reflected in enhanced social status or political influence. The predominance of the family business, for example, was closely related to the emphasis on the family as the pivotal unit in society, the limited means of pooling capital in the relative absence of reliable financial intermediaries, and the limited geographical range of most economic activities. In this Japan was no different from many other pre-industrial economies. However, while these forms of organisation had offered many strengths, they also posed limitations in the changed economic context of the late nineteenth century. Capital requirements were considerably greater for new manufacturing enterprises, while technological know-how and information to deal with international markets were in scarce supply.

The ability of the Meiji state to address both of these issues was limited. Popular perceptions could not be changed overnight, and the government did not see it as its responsibility to intervene in the organisation of private firms. While pilot factories might be appropriate for technology transfer, state-owned firms could not necessarily offer an organisational model for the private sector. There are two respects, perhaps, in which the government did seek to facilitate change and adaptation in this area. One was in its collusion in what might be called the 'myth' of the 'unique' nationalist entrepreneur. Recognising the need to rehabilitate the validity of economic activity as part of the national project, a recognition reinforced by the growing overt involvement in economic activity of former members of the elite samurai class, the state not only sought to give positive encouragement to specific initiatives, but also employed a powerful rhetoric to stress the extent to which entrepreneurship, investment and profitmaking were just as valid expressions of nationalism and patriotism as political or military service. It was business leaders themselves who were the most powerful advocates of this view, but they were able to count on government support in articulating it.

This concept of the 'nationalist' entrepreneur was taken up by a number of economic historians of Japan (e.g. Ranis 1955; Hirschmeier 1964), and at one point was even considered one of the keys to the supposed 'unique' pattern of Japanese development. The extent to which the Meiji commercial elite was driven by nationalism rather than the hope of profits has, not surprisingly, been questioned (e.g. Yamamura 1974), but what is important here is that this exercise in rhetoric and persuasion was a powerful tool in changing institutions in North's sense of informal rules governed by mental models. It demonstrates the strength of ideology as well as the ability of the ruling elite in Japan at this time, including the state, to exercise a major influence over hearts and minds in a process of 


\section{Janet Hunter}

'institutional learning'. Recent work has suggested that the post-Pacific War Japanese state retained a considerable expertise in moral suasion (Garon 1997), and we perhaps need to ask how far that ability still rests with the Japanese authorities, should they seek to utilise it.

The second key area of government involvement lay in establishing the legal framework for the operation of a modern company system. While the first joint-stock companies predated legislation, it was only when such legislation was established that they could become the widespread norm in company formation. Legal infrastructure allowing for financial institutions such as banks and stock exchanges, much of it copied from the West, inevitably shaped the forms of business organisation, but the multidivisional corporation of the US analysed by scholars such as Chandler and Williamson was rarely in evidence in Japan (Chandler 1977; Williamson and Winter 1991). Instead, as Fruin has shown, the specific ways in which firms and factories came to be organised were very much a response to the particular Japanese environment and the imperatives of late development. Entrepreneurs needed in particular to address the scarcity of the various resources required for the growth of an internationally competitive manufacturing sector, notably capital, knowledge and information (Fruin 1992). The best example of this response is perhaps to be found in the emergence of the zaibatsu, the great conglomerates that played a critical role in Japan's early industrialisation and reached their apogee in the interwar years. Usually family-owned, these concerns were held together by finance rather than any technological or organic interconnectedness. One way of understanding the formation of these concerns is to see them as an example of specialised investment in the interest of establishing credible commitments (Williamson 1983). What is clear, however, is that by internalising their need for scarce resources, the zaibatsu were increasingly able to achieve substantial economies of scope and reduce transaction costs to a level far lower than normally achievable in late industrialising economies. Family networks allowed for an initial pooling of capital, later supported by the evolution of powerful in-house banks, while possession of a single trading corporation within the group allowed for a focused development of knowledge about dealing with external markets. These organisations too, though, were strongly embedded in accepted social practice, that is, in pre-existing institutions. Constituent companies were held together not just by economic means such as cross-shareholding, but also by mechanisms such as strategic marriages and regular personal meetings (Morikawa 1992). These structures, however, took several decades to appear. At the end of the Meiji period, moreover, much of the Japanese economy remained dominated by pre-existing forms of business organisations. Small and medium firms, invariably owned by families and working mainly with family labour, continued to account for a high proportion of all enterprises. Over 40 years after the initial commitment to change was publicly made, only a minute proportion of all enterprises had taken on 
even a modified Western form of corporate governance. The 13,000 registered companies of 1911 operated against a backdrop of hundreds of thousands of individually or family-owned businesses operating along traditional lines. This complex picture highlights two key points of relevance to current debates. First, imported institutions only slowly made inroads into the traditional modes of operation. Second, even those imported institutions could only be of use in a context of adaptation.

\section{Change in the labour market}

Meiji period changes in the labour market and employee-employer relations take on a renewed topicality in the light of current discussion about the need to accelerate changes in Japanese employment practices. Again the picture is a highly complex one, particularly in view of the persistence of many small-scale family enterprises. It is clear, however, that the need to respond to the demands of mechanised factory production, and the employment within a single entity of labour on a larger scale than even the biggest 'manufactories' of the late Tokugawa period, required new modes of labour organisation. In principle the government throughout this period maintained a hands-off approach to the institutions of labour management, although concern over the effects of deleterious working conditions in factories did eventually lead the authorities to intervene to change the rules of the game in the labour market, in particular by pushing through protective legislation in the form of the first Factory Act right at the end of the Meiji period in 1910. Up until then large employers had consistently resisted what they saw as encroachment on their rights. ${ }^{6}$

This strong resistance did not mean that the process of change in labour and employment relations was a smooth or rapid one. Historical evidence suggests quite the opposite. Many early employers complained about the 'confused' state of employment relations consequent on the demise of the old employment and apprenticeship system, and even called for its reinstatement. Concerns about the unreliability, mobility and low quality of all workers were widespread, giving rise to fears of the potential for anomie and social upheaval inherent in the transition from the old to the new. The clash between the political and economic elite advocating change and the extent of social inertia that they often felt that they faced is well summed up in comments made by factory owners, who in the 1890s considered their workers as a race apart, benighted by barbarity, ignorance and idleness. The task of 'educating' the mass of the Japanese population in new ways of doing things was for this group at least a very real one. Overt conflict between factory employers and employees was recurrent through much of the Meiji period, taking forms that ranged from strikes and violence through to absenteeism and absconding. That the majority of employers were reluctant to countenance any external imposition of a clearly defined set of rules would seem to have been largely due to a 


\section{Janet Hunter}

reluctance to accept that inherent in regulation was the principle of mutuality of rights and obligations. The principle of mutual obligations between different groups in society had been widely accepted in earlier times, although the existence of hierarchy or patriarchy, and the actual allocation of power, might often act to distort and conceal the principle of mutuality. However, whereas Tokugawa employer-employee relations had also acknowledged this principle to some extent, the pronouncements and actions of many Meiji employers suggest that what they sought was a relationship in which the employer had the rights and the employee the obligations. Any legislation aimed at protecting the welfare of the workforce, and hence constraining the absolute authority of the employer, was strongly contested on the grounds that Western-style labour legislation was unnecessary in Japan, which was following its own development path in which the interests of both employers and employees were guaranteed by the utopian paternalistic, familial way in which enterprises were organised and managed. More cogent, perhaps, was the argument that such were the economic pressures on Japan's infant industries that changing the institutions of the labour market was an expensive luxury that neither state nor entrepreneurs could afford (Hunter 2003).

There are examples of employers themselves seeking to address the problems of transition in the labour market through collective action. In the textile industries, for example, employers sought to regulate the movement of labour between enterprises by adherence to an agreed set of practices which in many ways tried to deal with labour as with an inanimate commodity that could be bought or sold. Scholars who have looked at these attempts to influence labour market institutions disagree as to their effects (e.g. Tōjō 1990; Kanbayashi 2001; Nakabayashi 2001), but we can be sure that rapid economic expansion, and agency and enforcement problems invariably rendered these attempts less than fully effective. If we look at labour market institutions, therefore, the picture from the Meiji period is one of a considerable degree of continuity in large parts of the economy, and enormous upheaval in the sectors that were spearheading economic change, characterised by an absence of both formal and informal rules. Even by the end of the Meiji period most large employers, whether in the commercial or manufacturing sectors, were far from achieving a stable and widely accepted pattern of employment practices (Gordon 1985). A situation more different from the 'Japanese employment system' of the second half of the twentieth century is hard to imagine. Rhetoric and the recreation of tradition may well have been a powerful tool in linking this famed system to its Meiji and pre-Meiji heritage, but its reality can be dated back at the very earliest to the 1920s, with the sporadic appearance of some of its constituent elements in response to the constraints of labour supply faced by some enterprises. 


\section{Institutional change in the Meiji period: implications for the early twenty-first century}

It is not easy to draw out any implications that an analysis of late nineteenth century changes may have for Japan's current dilemmas. It has been emphasised here that there existed no single coherent pattern of institutional and organisational change in Meiji Japan. Change was a highly complex and patchy process, which in many cases took decades rather than years. The extent to which organisational or legislative change was able to lead institutional change in the Northian sense was at best unpredictable. The ability of the political and economic leaders to engineer and accelerate reform was often limited, and it was often the pragmatic response to the imperatives of late development that was a more powerful force for change than sophisticated debates or the presence of viable foreign models. Japan is clearly no longer 'relatively backward', and the catch-up imperative has ceased to obtain. A number of tentative observations may, however, be offered. These observations relate to apparent differences between contemporary Japan and the Meiji period, but also to some crucial similarities.

The first point relates to the role of human agents in institutional change, and the motivations for trying to bring it about. A major stimulus driving institutional change in the Meiji period was an awareness of national crisis and overriding threat reflected in the ability of the Western powers to impose on the national autonomy of Japan. Awareness of this threat was initially restricted to the ruling elite, but the effective manipulation of nationalist sentiment was a powerful tool in building and sustaining any momentum for change. It was this overriding sense of national crisis among the political elite that limited the destructiveness of internal divisions within the government and generated a political will for reform. Despite its problems, the Meiji oligarchy possessed both the desire and the ability to override and dismantle vested interests when it took the view that it was essential to do so. The abolition of the old domain system and the pensioning off of the former ruling warrior class was achieved within a decade of the Restoration, albeit at considerable political and economic cost. This process removed institutional barriers to change, in line with the Gerschenkronian paradigm. It also undermined the position of other groups, such as commercial elites and guilds, which might otherwise have been in a position to block change. ${ }^{7}$

The Meiji period therefore demonstrates that political decision-making and political resolution can be significant in promoting institutional change, and also in not impeding it. It also suggests, however, that the magnitude of a crisis, and the way in which it is perceived, may be important in the formation of political will and political leadership. It is for others to judge the role of the political elite in contemporary Japan, or how far nationalist sentiment remains a viable tool for articulating a unified 
national response, but the sense of urgency that might be applied to the cause of reform has to some extent remained muted. In part, perhaps, this may be due to the cushion offered by Japan's reserves of wealth, which have sustained the living standards of most Japanese in the face of economic recession and political and strategic uncertainties.

A second point is that the experience of the Meiji period suggests that the relative merits of importing institutions and modifying existing ones will vary according to each specific case. The benefits of Japan's following more closely elements of the Anglo-American model have been extensively touted over recent years, and the transition to private sector dominance and unfettered operation of the market has been advocated by some scholars as a panacea for Japan's economic woes. It may be that institutional transfer can signal a desire to embark on a completely new trajectory, but it can also be risky and just as time-consuming as efforts to grope for a new system based purely on what already exists. With appropriate modifications, borrowed institutions can over time be made to work, but they can also be so unsuited to the receiving environment that appropriate adaptation is impossible. As in the case of technology transfer, a successful process of institutional learning in Johnson's sense is related not just to economic and political needs, but to social capability more broadly. Where 'culture' is regarded as impeding institutional change, as it is at present, we also need to ask whether it is the way that culture is constructed that is the real obstacle, rather than the culture itself.

Two further points should be made, both of which relate to the fact that, compared with the Meiji period, what happens in Japan's economy now is of critical importance well beyond Japan's borders. The first of these is that the process of globalisation may in some ways have made it more difficult even for wealthy countries to implement the safety net required to protect the most vulnerable losers of the process of institutional and organisational change (Rodrik 1997). Japan has seemed at times unwilling or unable to pension off groups that might be damaged by change, and hence resist it. The prolonged battle over the liberalisation of agricultural markets is a case in point.

The second is that the dilemma that faces would-be reformers in Japan is perhaps more intangible than it was a century ago. The Meiji tenet of 'Japanese spirit and Western technology' embraced a recognition that in practical terms Japan had a great deal to learn, but that the country could retain a degree of confidence and belief in the Japanese intellectual and social tradition. While that confidence and belief was often distorted and misused in subsequent decades, it supported the existence of an ongoing self-respect in relation to Japan's position in the world, shaken but not destroyed by defeat in the Pacific War. By contrast, contemporary Japan is the world's technological leader, but Japan has not seized the international ascendancy commensurate with its enormous economic power. Many Japanese are beset with doubts as to the value of their own inheritance. It 
is the need to respond to pressure to combine Japanese technology with a Western spirit that is one of the greatest challenges for institutional change in Japan.

The obvious differences between the historical contexts of the late nineteenth and early twenty-first centuries should not, however, blind us to some crucial similarities associated with the process of potential and actual change. The complex picture that emerges of institutional change in the Meiji period suggests that fundamental institutional change is unlikely to occur within a very short timespan, for example a few years. Current expectations of rapid institutional transformations within a very short timeframe are likely to be totally unrealistic. Moreover, where there is institutional borrowing and institutional choice, there has to be accommodation with the existing institutional cluster or clusters. It is this that renders institutional change process rather than event. If recent reform attempts are considered in this way, then the difficulty of bringing about radical, across-the-board change with one-off, 'big bang' reform pushes or pieces of legislation becomes much more explicable.

All this presupposes, however, that contemporary Japan is as resistant to change, and as much a prey to institutional sclerosis, as the country's harshest critics have maintained. In fact there is, as some of the chapters in this volume show, growing evidence that changes have been occurring, including in the three areas noted in this paper. The financial sector has perforce experienced a number of painful reforms, even if there are still some who argue that these have not gone far enough. Corporate structures and networks have been modified, not least in conjunction with the involvement of non-Japanese economic actors. The Japanese employment system appears under threat. The extent of the changes that are taking place will, as in the Meiji period, only become apparent over a sustained period of time.

The image of institutional and organisational change in the Meiji years is that it was a well-planned and speedy process. The reality of change in the late nineteenth century was that the process was complex, difficult and uncertain. That same reality necessarily attends the process of reform in contemporary Japan, and cannot be wished away. It is almost impossible, moreover, for contemporaries to ascertain the direction and momentum of change, and certainly not both at the same time. Meiji period Japanese were beset by uncertainties, and had no way of knowing exactly what would be the long-term outcomes of their efforts, for better or for worse. The same is true of contemporary reform efforts. It may be suggested, therefore, that a gulf between image and reality likewise applies to the present. The reality of contemporary institutional change is not just that it, too, is complex and difficult, but that, contrary to the image of stasis and inertia, it is an actual and ongoing process. 


\section{Janet Hunter}

\section{Acknowledgements}

I would like to express my thanks to Sumner La Croix and Magnus Blomström for inviting me to participate in this project, and for their constructive comments on an earlier draft of this paper. I would also like to thank the participants in the project workshop for their helpful comments on my presentation, and the anonymous referee, to whose perceptive suggestions I have tried to respond.

\section{Notes}

1 For comment on this in relation to the 1990s crisis see Weinstein 2001. For a historical view see Lehmann 1978.

2 However, while the proactive role of the state and the recognition of Japan's own 'relative backwardness' fit the Gerschenkronian paradigm, in other respects its applicability to Japan was much less obvious. Japan's selective manufacturing advances and initial focus on light industry does not accord with the focus on advanced technology, heavy industry and across the board development identified in Russia. Moreover, whereas in less 'backward' economies such as Germany the banks were the main providers of capital for development, in Japan capital was provided through government, personal and family networks, banks and the open market, depending on the time and the venture.

3 For information on the Iwakura Embassy see Nish 1998. The diary of the whole mission is reproduced in Kume 2002.

4 For an account of political change see for example Ramseyer and Rosenbluth 1995; Sims 2001.

5 For a consideration of the organisation of Mitsui in relation to banking development in this period see Maat 1991. For the zaibatsu more generally, see Morikawa 1992.

6 See Hunter 2003 and also Chapter 6 of this volume for further information on the institutions of labour management.

7 Olson (1982) notes how the occupation authorities in post-Pacific War Japan were able to override distributional coalitions opposed to reform, but does not consider the case of the Meiji Restoration.

\section{Bibliography}

Andō, Yoshio (1975), Kindai Nihon Keizai Shi Yōran, Tokyo: Tokyo University Press.

Bordo, Michael and Hugh Rockoff (1996), 'The Gold Standard as a "Good Housekeeping Seal of Approval"', Journal of Economic History 56, 2: 329-428.

Chandler, Alfred D. (1977), The Visible Hand: The Managerial Revolution in American Business, Cambridge MA: Harvard University Press.

Chimoto, Akiko (1985), 'Shokkō Mondai Taisaku kara mita Meiji-ki Koyō Kankei', Shakai Kagaku 35: 126-77.

David, Paul A. (1994), "Why are Institutions the "Carriers of History"? Path Dependence and the Evolution of Conventions, Organisations and Institutions', Structural Change and Economic Dynamics 5, 2: 205-20.

Douglas, Mary (1985), How Institutions Think, New York: Basic Books.

Engerman, Stanley L. and K. Sokoloff (1997), 'Factor Endowments, Institutions 
and Differential Paths of Growth among New World Economies', in S. Haber (ed.), How Latin America Fell Behind, Stanford, CA: Stanford University Press, 260-304.

Fruin, W. Mark (1992), The Japanese Enterprise System: Competitive Strategies and Cooperative Structures, Oxford: Clarendon Press.

Garon, Sheldon M. (1997), Molding Japanese Minds: The State in Everyday Life, Princeton, NJ: Princeton University Press.

Gerschenkron, Alexander (1962), Economic Backwardness in Historical Perspective, Cambridge, MA: Belknap Press of Harvard University Press.

Gluck, Carol (1985), Japan's Modern Myths: Ideology in the Late Meiji Period, Princeton, NJ: Princeton University Press.

Goldsmith, Raymond W. (1983), The Financial Development of Japan, 1868-1977, New Haven, CT: Yale University Press.

Gordon, Andrew (1985), The Evolution of Labor Relations in Japan, Cambridge, MA: Harvard University Press.

Greif, Avner (1989), 'Reputation and Coalitions in Medieval Trade: Evidence on the Maghribi Traders', Journal of Economic History 49, 4: 857-82.

Greif, Avner (1993), 'Contract Enforceability and Economic Institutions in Early Trade: The Maghribi Traders' Coalition', American Economic Review 83, 3: 525-48.

Hazama, Hiroshi (1964), Nihon Rōmu Kanri Shi Kenkyū, Tokyo: Daiyamondosha.

Hirschmeier, Johannes (1964), The Origins of Entrepreneurship in Meiji Japan, Cambridge, MA: Harvard University Press.

Hunter, Janet (2003), Women and the Labour Market in Japan's Industrialising Economy: The Textile Industry before the Pacific War, London: RoutledgeCurZon.

Hunter, Janet (2004), 'Bankers, Investors and Risk', in Phillips O'Brien (ed.), The Anglo-Japanese Alliance, London: RoutledgeCurzon, 176-98.

Johnson, B. (1992), 'Institutional Learning', in B.-A. Lundvall (ed.), National Systems of Innovation: Towards a Theory of Innovation and Interactive Learning, London: Pinter Publishers, 23-44.

Kanbayashi, Ryō (2001), 'Tōkyū Chingin Seido to Jokō Tōroku Seido', in Tetsuji Okazaki (ed.), Torihiki Seido no Keizai Shi, Tokyo: Tokyo University Press, 161-235.

Kume, Kunitake (2002), The Iwakura Embassy, 1871-1873 (5 vols), Richmond, Surrey: Curzon Press.

Lehmann, Jean-Pierre (1978), The Image of Japan: From Feudal Isolation to World Power, 1868-1905, London: Allen \& Unwin.

Maat, Huuc C. (1991), 'Financial Development and Industrial Organisation in Japan, 1873-1899: The Case of Mitsui', Japan Forum 3, 1: 23-35.

Mokyr, Joel (2002), The Gifts of Athena: Historical Origins of the Knowledge Economy, Princeton, NJ: Princeton University Press.

Morikawa, Hidemasa (1992), Zaibatsu: The Rise and Fall of Family Enterprise Groups in Japan, Tokyo: University of Tokyo Press.

Nakabayashi, Masaki (2001), 'Seishi Kōjo Torihiki no Kōteki Tōchi to Shiteki Tōchi', in Tetsuji Okazaki (ed.), Torihiki Seido no Keizai Shi, Tokyo: Tokyo University Press.

Nish, I.H. (ed.) (1998), The Iwakura Mission in America and Europe: A New Assessment, Richmond, Surrey: Japan Library. 


\section{Janet Hunter}

North, Douglass C. (1981), Structure and Change in Economic History, New York: W.W. Norton \& Co.

North, Douglass C. (1990), Institutions, Institutional Change and Economic Performance, Cambridge: Cambridge University Press.

Ogura, Shinji (2002), Banking, the State and Industrial Promotion in Developing Japan, 1900-73, Basingstoke and New York: Palgrave.

Okazaki, Tetsuji (ed.) (2001), Torihiki Seido no Keizai Shi, Tokyo: Tokyo University Press.

Olson, Mancur (1982), The Rise and Decline of Nations, New Haven, CT: Yale University Press.

Ramseyer, J. Mark and Frances Rosenbluth (1995), The Politics of Oligarchy: Institutional Choice in Imperial Japan, Cambridge: Cambridge University Press.

Ranis, Gustav (1955), 'The Community-Centred Entrepreneur', Explorations in Entrepreneurial History 8, 2: 80-98.

Rodrik, Dani (1997), Has Globalisation Gone Too Far? Washington: Institute for International Economics.

Sims, Richard (2001), Japanese Political History since the Meiji Restoration, 1868-2000, London: C. Hurst.

Sussman, Nathan and Yishay Yafeh (2000), 'Institutions, Reforms, and Country Risk: Lessons from Japanese Government Debt in the Meiji Era', Journal of Economic History 60, 2: 442-67.

Suzuki, Kenji (2002), 'Organisational Learning Capacity of Policy-making System for Financial System Recovery: The Case of Sweden with some Suggestions for Japan', paper presented to Japan Public Choice Society (July).

Tamaki, Norio (1995), Japanese Banking: A History, 1859-1959, Cambridge: Cambridge University Press.

Tatemoto, Masahiro (1981), 'Gold, Silver and Paper Money Muddles Before and After the Meiji Restoration', ICERD International Studies Discussion Paper, LSE.

Tōjō, Yukihiko (1990), Seishi Dōmei no Jokō Tōroku Seido, Tokyo: Tokyo University Press.

Weber, Max (1963), The Religion of China: Confucianism and Taoism (tr. H. Gerth), New York: Macmillan.

Weinstein, David E. (2001), 'Historical, Structural and Macroeconomic Perspectives on the Japanese Economic Crisis', in M. Blomström, B. Gangnes and S. La Croix (eds), Japan's New Economy: Continuity and Change in the 21st Century, Oxford: Oxford University Press, 29-47.

Westney, D. Eleanor (1987), Imitation and Innovation: The Transfer of Western Organizational Patterns to Meiji Japan, Cambridge, MA: Harvard University Press.

Williamson, Oliver E. (1983), 'Credible Commitments: Using Hostages to Support Exchange', American Economic Review 73, 4: 519-40.

Williamson, Oliver E. and Sidney G. Winter (eds) (1991), The Nature of the Firm: Origins, Evolution and Development, New York: Oxford University Press.

Yamamura, Kōzō (1974), A Study of Samurai Income and Entrepreneurship, Cambridge, MA: Harvard University Press. 


\title{
3 Institutional reform in Japan and Korea

\author{
Why the difference?
}

\author{
Chung H. Lee
}

\begin{abstract}
The reality of a political-economic system is never known to anyone, but humans do construct elaborate beliefs about the nature of that reality beliefs that are both a positive model of the way the system works and a normative model of how it should work.

Douglass C. North $(1999,10)$

The theorists of "the end of ideology" and "the end of history" forget all this. For them, we have reached the point in time where no ideology is relevant and no utopia is pertinent. We have reached the final equilibrium of capitalist liberal democracy, and no learning or discovery [are] possible.

Geoffrey M. Hodgson $(1999,9)$
\end{abstract}

\section{Introduction}

Why has Japan been slow in carrying out economic reforms - reforms that many astute observers of the Japanese political economy have been saying for some years now are needed? The answer commonly offered by many of those observers is that opposition by powerful interest groups has blocked reforms from taking place. For instance, according to Yamazawa (2003), the farmers, construction companies, banks, and small and medium-sized enterprises and the Liberal Democratic Party (LDP) they support have formed an effective coalition against institutional reform. For Sato (2002), it is the "triad of elite bureaucracy, political parties, and big business" that has "been dragging their feet, [thus] stalling deregulation to protect their own interests" (p. 234). While there may be disagreement as to exactly who these powerful groups are, there appears to be no dispute over the reason why Japan has not been able to carry out economic reforms: that is, but for the opposition by powerful interest groups Japan would have carried out the necessary reforms and would have made a rapid recovery from the economic malaise that began in $1990 .{ }^{1}$

While agreeing with the view that Japan's powerful interest groups have blocked the necessary economic reforms from taking place, La Croix (2002) finds nothing extraordinary about its laggardly response to the crisis, 
as rich countries such as Japan are typically slow in responding to a crisis. Pointing out that it took ten years for New Zealand and two decades for Switzerland to carry out their respective reforms, he offers three reasons why such rich countries are slow in changing their institutions in response to a crisis: first, people in rich countries can afford to wait; second, institutions by their own nature cannot be too pliant; and third, policymakers in rich countries believe that they are already carrying out the right policies and are not, therefore, inclined to carry out extensive reforms. ${ }^{2}$

If La Croix is correct, Japan will eventually undertake economic restructuring such as corporate downsizing and solving the nonperforming loan problems. Indeed, since the 1970s Japan has been deregulating a number of industries such as domestic airlines, telecommunications, electricity, and retail business, although deregulation has been limited by and large to reforming and liberalizing existing regulatory regimes (La Croix and Mak 2001). Such deregulation or restructuring may not be enough, however, to restore Japan's economic health, as it has been made in a piecemeal manner out of fear and necessity and not as part of "overall understanding of the causes of Japan's current difficulties and a uniquely Japanese solution" (Porter et al. 2000, 187). Such a solution may require, as Lincoln (2001) has observed, a systemic change in Japanese society - a change in the "basic rules and practices that constitute the architecture for economic behavior" (pp. 6-7). The prospects for such a change are not good, however, as long as there is a strong consensus among the Japanese that their current system conforms to what they believe to be "broader social norms and expectations, representing values that society is loath to lose" (p. 8). ${ }^{3}$

South Korea (henceforth Korea), in contrast with Japan, undertook major economic reforms soon after the 1997-98 crisis. The speedy pace of the reforms may have been due to the fact that Korea is not as rich as Japan and was suffering from a severe economic crisis rather than an economic malaise. This may suffice in explaining the difference in reform experience between the two countries. I, however, argue that there is an additional, rather critical, factor that accounts for the difference: that is, for a country to change its institutions it, at least those advocating the change, must have a model of institutions that they and the society at large can accept as superior to the extant institutions. I argue that Japan has yet to find such a model, whereas Korea has had one since the early 1980s.

As is well known, Japan has gone through two major institutional reforms in its modern history - the Meiji Reform of 1868 and the postWorld War II reform. The model for the first was many of the institutions in the West, as the term "Westernization" then used to describe the reform clearly suggests (Fairbank et al. 1965). The second was imposed by the Supreme Command for the Allied Powers (SCAP) and was patterned after many American institutions (Dower 1999). In those two earlier cases Japan was compelled to reform its institutions by outside forces and had 
definite models to follow. This time the situation is different: given that Japan has successfully caught up with the West with a political-economic system that is often claimed to be uniquely Japanese, many in Japan, even those who advocate a systemic reform, lack a clear vision or a model for institutional reform. ${ }^{4}$

Korea was in an economic crisis in 1997-98 and was forced to carry out major institutional reforms. But even before the crisis, there was a strong move to establish a liberal economic order, a move pushed for and supported by many in academia and officialdom as well as by the chaebols, the large, family-owned conglomerates in Korea. In fact, the only group opposed to reform was government bureaucrats who had much to lose with the establishment of a liberal market economy. Many of the reforms undertaken since the early 1980s - mostly deregulation - may have been done "incorrectly," thus planting the seeds for the 1997-98 crisis, but there was nevertheless no dispute over the reforms' ultimate goal - the establishment of a liberal market economy in Korea. That is, there was no ideological homage to the system of political economy introduced by the military government in 1961, and there rarely was, as far as I am aware, the idea that the system was deeply rooted in Korean culture and tradition. ${ }^{5}$ Rather, the change away from that system, which Amsden (1994) calls the Japanese-German late-industrialization model, was extensive enough to prompt her to say that Korea was becoming "Anglo-Saxonized" - a move, she claims, championed by "American-trained Korean economists." What the crisis of 1997-98 did was to provide an impetus for speeding up the pace of the reform that had been in progress in Korea since the early 1980s.

In the following section I argue that, although there are signs of change, the view that Japan's political economy is unique, deeply rooted in its culture and tradition and whatever may replace it will also have to be compatible with the cultural heritage is still widely held. It would not be surprising if finding such a system took longer, there being no model to follow, than adopting a ready-made system from abroad even if there were no opposition to reform by powerful interest groups. ${ }^{6}$ To put it differently, Japan is now in a paradigmatic crisis, a crisis in the beliefs held by many Japanese about their own political-economic system, and is in need of finding an alternative paradigm that the people can accept - a process that inevitably takes a long time. ${ }^{7}$ We should note that this is not the first time Japan has encountered such a crisis and it was at times of such crises that major systemic institutional reforms took place in Japan.

According to Harumi Befu (1993), Japan's national policies and institutions are predicated upon its national identity that is encapsulated in Nihonjinron - a "broadly based ideological stance for Japan's nationalism." He divides Japan's modern history into the following five distinct periods of Nihonjinron, which has alternated between "unqualified ethnocentrism, extolling Japan's cultural genius" and "depressed soul-searching." The first 


\section{Chung H. Lee}

half of the nineteenth century was a period of strong positive Nihonjinron, with China as the inferior reference group; the second half of the nineteenth century through the 1920 s was a period of strong negative Nihonjinron, with the West as the superior reference group; the 1930s to 1945 a period of strong positive Nihonjinron with the admiration of the West suppressed; 1945 through the 1960s a period of strong negative Nihonjinron with admiration and envy of the West; and the 1970s to the time of the publication of Befu's book (circa 1993) a period of strong positive Nihonjinron with admiration and envy of the West giving way to disrespect. Looking at these five periods, we see, not surprisingly, that systemic institutional reforms took place in Japan only during the periods of strong negative Nihonjinron. Those are the periods when the institutions once held up by the Japanese as the "epitome of virtue and goodness" came to be regarded as the "curse of the nation."

If institutional reforms in Japan take place only during a period of strong negative Nihonjinron, there will have to be a change from positive Nihonjinron to a negative one before they are undertaken. If this is correct, the current paradigmatic crisis will have to lead to a change in national identity before reforms can take place. The economic malaise that seems to defy all attempts at cure and China's emergence as a major economic power may prompt this change, but when and how soon that will happen remains an open question. ${ }^{8}$

From pages 80 to 86 I discuss the reform experience of Korea, where, unlike in Japan, the idea that its political economy is unique and deeply rooted in its culture and tradition is not widely shared. Very few have argued that the political-economic system that was established by the military government in the 1960s is based on its culture and tradition, and when changes took place in that system there were few ideological oppositions voiced against adopting institutions from abroad. In other words, in 1997-98 Korea was in an economic, not a paradigmatic, crisis and, consequently, its institutional reforms did not require a change in the paradigm that people in Korea held about their political-economic system. Thus, reforms came about more rapidly in Korea than in Japan. The chapter ends with some concluding remarks.

\section{After catch-up, what now?}

Unless material wealth can successfully be turned into a sense of national identity and mental well-being, the Japanese will find themselves in a perpetual catch-up syndrome, always in a state of restlessness and mental hunger. It is about time that we take stock of our situation, live our lives at our own pace, and form our policies accordingly.

(Sakakibara 1993, 11) 
Second, the difficulty in achieving reform is not limited to resistance grounded in distributional conflict. The difficulty in changing enduring expectations brought about by cognitive and ideological factors exacerbates the problems of social reform.

(Knight 1992, 213)

Ideologies are, to quote Denzau and North $(1994,4)$, "the shared framework of mental models that groups of individuals possess that provide both an interpretation of the environment and a prescription as to how that environment should be structured." As such, ideologies have a powerful influence on the institutional reform a country may choose to carry out. ${ }^{9}$ In this section I argue that many in Japan share the ideology that Japan's political-economic system is unique, based on their culture and tradition, and that that ideology constrains the prospective institutional reform in Japan. To put it differently, Japan will be following a course of reform different from that of other reforming countries, such as the former republics of the Soviet Union, where reforms are based on the ideas of technopols - the highly trained social scientists brought into a position of political influence by a crisis - that are "usually based on the Anglo-Saxon economic tradition and consistent with the views of the multilateral institutions" (Edwards 2001, 16).

The conventional wisdom that Japan has not been able to carry out institutional reforms because of the opposition by powerful interest groups is based on the assumption that, although a majority of people in Japan realize that they will benefit from institutional reforms, they are unable to organize and overcome the opposition due to the collective action problem à la Olson (1971). I argue here that this is a flawed assumption based on the notion that those who are not members of powerful interest groups believe that the extant system only serves the interest groups, and a reformed system - one similar to the Anglo-American system - will provide them with greater benefits. The fact of the matter is that although doubts about it appear to be growing in recent years, a view still widely held among government officials, businessmen, and Japanese academics is that the nation's political economic system is a successful institution, superior to those of Western nations, as it has helped their country to catch up with the West with material benefits shared widely and equitably within the nation (Lincoln 2001, 202). This view may be only an illusion, but then, as North (1999) points out, the reality of a political-economic system is never known to anyone and it is the beliefs, whether correct or not, about the nature of that reality that guide people in their action.

In their summary of reform histories of 13 countries, ranging from Australia to Turkey, Williamson and Haggard (1994) argue that during the 1980s there occurred a profound change in the intellectual climate in the West toward what is now commonly called neoliberalism and that its spread to those countries had a powerful influence in their reform of 


\section{Chung H. Lee}

economic policies. This observation has two points relevant to our discussion here. One is that reforming a political economic system is not simply a matter of overcoming opposition by powerful interest groups; it also requires a change in the intellectual climate or paradigm of the system. ${ }^{10}$ The other is that in Japan, a country that regards its political-economic system as unique, a change in the intellectual climate has yet to take place.

The Japanese political economy, especially the one introduced after World War II, has been given such names as "nonliberal capitalism," "developmentalism," "non-capitalistic market economy," "mixed economy à la Japonaise," "Japanese capitalism," and "Japanese-style capitalism" to differentiate it from the Anglo-American capitalism. Nonliberal capitalism, which Streeck and Yamamura (2001, 6) argue characterizes the German and Japanese economies, is a system of political economy where "various forms of hierarchical and organizational coordination that sometimes require heavy injections of public authority" are used with "vertical control or horizontal collective bargaining often overriding contractual exchanges as entered into by private agents on their own volition, discretion, and calculation." Developmentalism is, as defined by Murakami, an

economic system that takes a system of private property rights and a market economy (or. in other words, capitalism) as its basic framework, but that makes its main objective the achievement of industrialization (or a continuing growth in per capita product), and, insofar as it is useful in achieving this objective, approves government intervention in the market from a long-term perspective.

(Murakami 1996, 145-6)

The fact that the Japanese economic system is given various names to differentiate it from the Anglo-American system does not necessarily mean that it is truly different. ${ }^{11}$ Likewise, the fact that Japan used industrial policy to hasten economic growth in the post-World War II era and has in fact succeeded in catching up with the advanced industrial countries of the West does not prove that it was effective. ${ }^{12}$ These issues, however important they may be, are of no concern here. What we are interested in is rather the reasons for the labels given to differentiate the Japanese political economy from the Anglo-American system and the reasons why industrial policy is said to have been effective in Japan, as they provide us with an insight into why reforms have been slow in taking place in Japan.

According to Okimoto (1989), the main contribution that industrial policy made to Japan's economic success was the promotion of communication and consensual policymaking between government and business, and the strengthening of public-private policy networks. ${ }^{13}$ These networks are based, he argues, on long-term obligatory and affective ties and have given Japan's political economy extraordinary flexibility, which con- 
tributed to its catching up with the more advanced industrialized countries of the West in a short span of time.

Japan's policy networks are based, according to Okimoto, on ascriptive relations such as marital and kinship relations (keibatsu), the common place of origin, contact through mutual friends, school connections ( $g a k u$ batsu), and on functional ties that emerge from friendships developed in the course of government-industry contact, participation in informal study groups, and amakudari networks. As he put it, these public-private policy networks are an exemplary case of the "fusion" of what is normally regarded as mutually exclusive opposites in the West - market and organization, public and private, and formal and informal. And, this fusion is a notable characteristic of government-business relations in Japan and a byproduct of Japan's deep-rooted socio-cultural values, which give "distinctive shape and life to the institutions of Japanese capitalism" (Okimoto 1989, 237). ${ }^{14}$

It is clear that by "Japanese capitalism" Okimoto means that because of its unique socio-cultural values Japan's political economy is different from that of the West. Morishima (1982) is more specific about the reasons for the difference: "Western-style" capitalism is based on a "rational religion aimed at emancipating the individual," whereas the "Japanese-style" capitalism is rooted in a "religion aimed at justifying the status quo" (p. 197).

Murakami and Rohlen (1992) also argue that Japan's political economy is different from that of the West. They point out that policy networks, which were critical for the effectiveness of Japan's industrial policy in promoting economic growth, are based on social exchange between government and business - a mode of exchange that entails long-term unspecified obligations on the part of participants. ${ }^{15}$ This social exchange is, they argue, what has made Japanese businesses comply with the government's administrative guidance even when there are no statutes compelling them to do so. There is the "implicit give-and-take operating in a long-term framework in which both government and private firms get what they want - that is, a social exchange framework" (Murakami and Rohlen 1992, 91). Such a framework is necessarily exclusive in nature, with benefits and obligations of social exchange (and security thus provided) limited to the select participants.

Cognizant of the changes in Japan's political economy in the late 1980s, Murakami $(1987,84)$ pointed out that the catch-up model that Japan had used in the post-World War II era was no longer appropriate for the new society. He argued that Japan should "prepare sufficient room for creative adventures, technological as well as social, without being afraid of the possible risks involved. This is liberal in a wide sense and is contrary in many ways to the Japanese approach in the catch-up phase." ${ }^{\prime 6}$ Japan, he predicted, is likely to fail to maintain its level of prosperity unless it overrides the institutional inertia from the past, but he does not foresee Japan 
78 Chung H. Lee

adopting the Western-type individualism. As he sees it, the Japanese political economy, such as its mode of decision-making ("long-term, multiissued, often implicit agreements"), which accounted for the success of the Japanese economy in the post-World War II era, is based on Japan's deeprooted socio-cultural values that will remain more or less unchanged.

The Japanese system of political economy, which, according to Hayami $(2001,328)$, is a product of an evolutionary process involving "conflicts, compromises and synthesis between the traditional value system and the imitated Western institutions and organizations," is a "nexus of pseudocommunity organizations." That is, in Japan, a firm simulates a community while several firms are grouped together under a "community spirit." They in turn establish a community relationship with government agencies. This "multi-stranded nexus of communities" has served Japan well, according to Hayami, by reducing moral hazards and transaction costs.

But Hayami (1998) has also argued that this catch-up model of Japan is no longer effective in sustaining economic growth and will have to be replaced with a new model of society that promotes innovative ideas and concepts. In that society, free competitive markets will have replaced the community or social exchange relationship both within and between corporations, and entrepreneurs will be encouraged to innovate with proper rewards. What is needed for such a society to be established in Japan is, according to Hayami, the removal of government controls and regulations that were put in place during the catch-up period of Japan's economic development. He is, however, silent about how the controls and regulations can be removed when they are part and parcel of the "multi-stranded nexus of communities" that, as some have argued, are rooted in Japanese culture and tradition.

Gyohten (2000) is another astute observer of the Japanese political economy who has argued that Japan needs to adopt new principles such as "competition, transparency, accountability and self-responsibility" if it is to pull itself out of the current economic malaise. But he also points out that adopting those principles would mean an almost complete turnaround or almost complete denial of the traditional Japanese principles that had served the nation well in the past. In other words, it would mean doing away with traditional practices such as "corporate social responsibility, stable employment and human orientation, the maintenance of social order." These are social exchange relations between big businesses and their employees and between them and society at large that have been a part of social fabric in Japan for many years, and terminating those relations will not be an easy matter for anyone on either side of the relationship. The government will, for example, have to let the insolvent firms that have been its partners in social exchange go bankrupt, but doing so will be violating a relationship of trust and cooperation between members of that social exchange. The same reluctance is exemplified in the government's attempt to carry out regulatory reform, as economic regulation has been 
used as a means for achieving social policy goals such as sustaining the viability of small producers in declining industries, and as doing away with it would be an abrogation of a "social contract" with those small producers (Carlile and Tilton 1998). In other words, institutional reform in Japan is not simply a matter of getting rid of certain government regulations by overcoming the opposition by special interest groups but is more involved, in that it would require changing a fundamental relationship between government and society that had underlain such regulations.

This brief review of writings by some of the highly knowledgeable observers of the Japanese political economy is obviously not exhaustive but nevertheless captures, I believe, the dominant view held by Japan's opinion-makers and policymakers about the Japanese economy and what the new model for Japan is to be. That is, it points out that, in the eyes of many of the influential Japanese thinkers and opinion-makers, Japan's political economy is different from those in the West and whatever may replace it will have to be compatible with its deep-rooted culture and tradition.

The idea or belief that institutional reform in Japan has to be compatible with its culture and tradition has a long history. When Shōtoku Taishi (574-622 AD) set out to modernize the structure of Japan's imperial government in the early part of the seventh century it was the Chinese system of administration that presented a model for reform. The borrowing from China was carefully circumscribed, however, such that there would be only "graft[ing] Chinese ability onto the stock of Japanese spirit" (Morishima 1982, 23). At the time of the Meiji Restoration in 1868 Japan learned a list of things to borrow from the "senior" nations of the West, but again its "Westernization" was guided by the principle of wakon yōsai (Japanese spirit with Western ability) (Morishima 1999, 44). In those two historical cases Japan clearly had a model or "navigational chart" to follow, although the reform was to be in conformity with the "Japanese spirit." What distinguishes the present situation from those two earlier cases is that, having caught up with the West, Japan has "no similar navigational chart" to guide its reform (Morishima 1999, 44).

Rightly or wrongly, Japan is groping for a new system of political economy of its own creation and not following or emulating a model that is well established in other societies. This new system is not going to be patterned after the Western system, as with Japan's parity with the West now "shame is displaced as motivating agent by the pride of honour, Westernisation by a resurgent nostalgia for the authentically indigenous patrimony of culture" (Dale 1986, 176). The two reforms of the past, although patterned after models abroad, did not require a fundamental change in Japanese ethos, at least in the eyes of the Japanese. The system created after the Meiji Restoration was a capitalism that conformed to "Japanese spirit" - state capitalism that is "nationalistic, paternalistic and antiindividualistic" (Morishima 1982,18). The viability of that system is now 
being questioned, but in the eyes of many Japanese it cannot be replaced with the individualistic Anglo-American model because they regard it as antithetical to the Japanese ethos of collectivism and the "Japanese spirit." 17 Worse, as they see it, the Anglo-American model might only bring in the "disadvantages of the capitalistic system, such as a wider gap in income distribution, rampant money worship, and the vulgarisation of culture, or superficial fashions" (Sakakibara 1993, 141). This time Japan has no model that it can emulate to its advantage and will have to create a system of its own - a process that will necessarily take a longer time than adopting an off-the-shelf model that has been used in other countries. ${ }^{18}$ Sakakibara may have captured the mood of the nation when he said that "[i]t is about time that we take stock of our situation, live our lives at our own pace, and form our policies accordingly" $(1993,11)$.

\section{No "Korean capitalism" in Korea}

Until recently Korea also practiced industrial policy, which began with the establishment of a military government in 1961. The government set economic development as a top national priority and, as a means of achieving it, nationalized most of the commercial banks and assumed the power to appoint the heads of all the commercial banks. It also established several special purpose banks such as the Korea Development Bank (1961), Kukmin Bank (1963), and the Foreign Exchange Bank (1967), all engaged in administering "policy loans" on behalf of the government. The banks in Korea - commercial as well as special purpose - thus became merely an arm of the government for allocating credit for developmental objectives.

This system of political economy that put the Korean state in command of the key factor market closely resembled the system that Japan used successfully during its post-World War II recovery (e.g. Amsden 1994; Cho 1994; Pyung Joo Kim 1994)..$^{19}$ This is to be expected, as President Park was trained at a Japanese military academy during Japan's colonial occupation of Korea and looked at Japan as a model for economic development and, having little regard for academic economists, relied on economic experts who had been educated in Japanese schools and had worked in Japanese banks for economic management (Woo 1991).

In 1965 the Korean government carried out its first financial reform with the advice of American academic economists. Although the reform allowing the interest rates paid by government-owned commercial banks to match the market rates - has often been cited as an exemplary case of a successful financial liberalization, in reality it only expanded the financial resources available for policy loans by diverting funds from unregulated informal markets to the government-owned commercial banks, with virtually no effect on the basic direction of the government policy. The following quote from Pyung Joo Kim is quite revelatory of what the reform actually accomplished: 
During this period a host of U.S. advisors (E.S. Shaw, John Gurley, Hugh Patrick, and others) visited Korea frequently under the auspices of USAID and international organizations. Their recommendations were put into practice with much fanfare and had an apparently dramatic effect for a while. These experiments, imbued with American ideas and implemented by officials more susceptible to U.S. influence, made ripples on the surface of Korea's financial structure. In most cases, these experiments were short-lived, distorted, ignored, and eventually overwhelmed by the main currents flowing steadily under the surface.

(Pyung Joo Kim 1994, 278, italics added)

In 1980, when General Chun Doo Hwan took over the government in a military coup following the assassination of President Park, the Korean economy was in severe crisis - a high rate of inflation, a terms-of-trade deterioration resulting from the second oil crisis, and excess capacity and low profitability in some of the government-promoted heavy and chemical industries (Organization for Economic Cooperation and Development 2000). The very survival of the new government was at stake, especially since it lacked political legitimacy, and restoring the economic health became an imperative for its own survival. Continuing with the policies of the previous regime was not an option open to the government since they were regarded as responsible for the crisis. The course of action that the government opted for instead was to radically change the policy regime by bringing in a number of reform-minded liberal economists (Moon 1994).

One such individual, brought in as the chief economic advisor to President Chun to help manage the crisis and carry out an economic reform, was a Stanford University-trained economist named Kim Jae Ik. He and his like-minded colleagues prepared a major reform agenda for the new government, basing it on the lessons they had learned at major American universities. As to be expected, the agenda they presented consisted of a reduction in government deficit, a tight monetary policy, a restraint on the growth of wages, trade account liberalization, relaxing control over foreign investment, privatization of major commercial banks, and phasing out the subsidies to heavy and chemical industries (Kim 1991). These are exactly the set of policies that subsequently came to be known as the Washington consensus - fiscal discipline, appropriate public expenditure priorities, tax reform, financial liberalization, appropriate exchange rate policy, trade liberalization, abolishment of barriers to foreign direct investment, privatization, deregulation, and property rights (Williamson 1994). ${ }^{20}$

This congruence between Korea's reform agenda and the Washington consensus is no surprise, given that Kim and most, if not all, of his colleagues were trained in economics at major American universities where neoclassical economics has been dominant. With the support of a president who admittedly was a tabula rasa in economics and, unlike his 
predecessor in office, had no vision of his own for steering the economy, the newly empowered reform-minded economists were able to translate policy prescriptions based on the neoclassical economics they had learned into a concrete reform agenda in Korea (Woo 1991).

As part of this reform agenda the government launched a new round of financial liberalization, far more substantial than the one in 1965. It sold off government-held shares in commercial banks while imposing an 8 percent limit on the number of shares of a bank that an individual person or a chaebol firm could own. It also removed a number of entry restrictions, thus making possible the establishment of foreign joint-venture banks, non-bank financial institutions (NBFIs), insurance companies, regional banks, and security companies. The commercial banks were also given the freedom to set interest rates on regular deposits and loans and on corporate bonds, commercial papers, and transferable certificates of deposit. NBFIs were also given more freedom in setting interest rates.

But again, as in the case of the 1965 reform, the financial liberalization of the 1980s was more about interest rate deregulation and less about credit allocation. Although the share of policy loans in total domestic credit was reduced from 50.4 percent in 1970-74 to 28.1 percent in 1990-94, a consequence of the growth of NBFIs, their share of bank loans remained more or less the same -47.8 percent in 1972 and 47.5 percent in 1990, although it fell as low as 39.3 percent in 1985 (Kong 2000, table 3.1). Such a large share of policy loans is a clear indication that in spite of financial liberalization the government retained a powerful influence over bank credit allocation through various administrative measures that were not apparent to outside observers.

As in the case of Japan, there is much controversy over the effectiveness and efficiency of industrial policy in Korea. Among the defenders of the system are Amsden (1989) and Wade (1990), who argue that the Korean government successfully used industrial policy - a non-AngloAmerican system of political economy - to bring about rapid economic growth. They do not, however, attribute the success of industrial policy in Korea to its culture and tradition.

This author (Lee 1992) also argues that industrial policy was efficient in promoting economic growth during the early phase of Korea's industrialization. His rationale of the success of industrial policy is that close relations between the government and the chaebol in Korea resembled those in a hierarchical, internal organization and that the government and the chaebol in Korea should thus be viewed as constituting a "quasi-internal organization" and state intervention with private firms as an equivalent to internal directives of the corporate head office to its subunits in a multidivisional corporation. It then follows that intervention by the state can be effective and efficient in achieving its developmental objectives, as directives of corporate headquarters can be effective and efficient in achieving corporate objectives. It is, however, important to note that, in the author's 
argument, the quasi-internal organization did not derive its efficiency from Korea's culture and tradition but from its ability to economize the transaction costs à la Williamson (1975). That is, there is no "Korean capitalism" in Korea.

\section{Interest politics and financial reform in Korea in the $1990 \mathbf{s}^{21}$}

The fact that in Korea there is no "Korean capitalism" and no equivalent to Japan's wakon yōsai does not mean that financial reform in Korea was carried out strictly in accordance with the principles of financial liberalization. Korea also has powerful interest groups and their parochial interests influenced the way in which financial reforms were carried out. This section discusses various financial reforms in Korea in the 1990s and the influence of various interest groups on their outcome.

\section{Domestic liberalization: entry and interest rate deregulation}

In the early 1990s, the government deregulated the entry and business scope of financial institutions in order to promote competition in financial markets and thus increase their efficiency. In 1994 nine such merchant banks were established, with the addition of 16 in 1996. Many of these merchant banks were formerly investment finance companies owned and controlled by the chaebol, which remained as the owners of the newly created merchant banks.

Another important deregulation in domestic financial markets was a significant loosening of restrictions on the chaebol's ownership of other NBFIs such as life insurance companies and investment trust companies. Before the deregulation, the top 15 chaebol firms were not allowed to own and control life insurance companies while the next top 15 chaebol firms were allowed to have only up to a 50 percent ownership of life insurance companies. But in May 1996 all chaebol firms but the top five were allowed to own and control life insurance companies. Also, before the deregulation, only the commercial banks could own investment trust companies, but in 1996 that restriction was abolished, resulting in the chaebol's control of many of the investment trust companies.

In the 1980s the government was not successful in deregulating interest rates because the chaebol were opposed to it in fear of a heavier interest burden that higher market-determined interest rates would impose on them (Choi 1993). In the 1990s, however, much progress was made in interest-rate deregulation because the chaebol saw an advantage in having free NBFIs and thus freer access to credit, albeit at higher interest rates than charged by the still-regulated commercial banks. Thus, in 1993 the government was able to declare the deregulation of all lending interest rates (except for policy loans) and many deposit interest rates, including long-term savings, corporate bonds, certificates of deposit, and checking 


\section{Chung H. Lee}

accounts. The actual implementation of this deregulation policy took, however, a bizarre course.

As originally planned, long-term interest rates were to be deregulated before short-term interest rates. In the event, however, short-term interest rates such as the rates on the certificates of deposit and commercial papers of NBFIs were deregulated first in a speedy manner, while time deposit rates of commercial banks were still under de facto government control. In loans, too, commercial bank lending rates and corporate bond interest rates remained subject to administrative guidance when all restrictions were removed from interest rates on NBFIs' commercial papers and from the amount that they could issue.

A consequence of this "short-term commodities first, long-term commodities later" deregulation was a rapid increase in the share of commercial papers in firms' external financing from 7.6 percent in 1992 to 16.1 percent in 1995 (Cho 1999). High-yield commercial papers and other short-term instruments became an important part of financial transactions, with NBFIs being a major player in that business. As a result, the Korean financial market came to be dominated by short-term financial activities with a concomitant rise in overall financial risk. It also became a dualistic structure consisting of tightly controlled commercial banks still lending at low controlled interest rates and rapidly growing and relatively free NBFIs headed by merchant banks, many of which were owned by the chaebol, lending at higher market-determined interest rates.

\section{External liberalization}

Given that the top 30 chaebol firms were subject to an aggregate ceiling in the amount of bank credit they could obtain, they naturally turned to NBFIs for financing. They also sought financing from offshore banking and began demanding the liberalization of international financial transactions. This demand coincided with the pressure from international financial capital for access to the Korean market. The Korean government itself had good reason for accommodating this demand since it was keenly interested in joining the Organization for Economic Cooperation and Development, which required Korea's capital-account opening as a condition for its membership. This conjunction of forces made the post-1993 financial opening of Korea one of the most rapid and comprehensive ones in the developing world.

The measures taken to open the capital account included removing regulations on the issuance of foreign currency denominated bonds by domestic firms and financial institutions, export-related foreign borrowing and general commercial borrowing, and abolishing the annual ceiling on foreign currency loans by financial institutions. These measures did not, however, apply equally to both long-term and short-term transactions: short-term transactions were fully deregulated, while long-term transactions were either partially deregulated or not at all. 
Why did the government carry out such unbalanced financial opening? The idea of financial liberalization was not something to which the Korean government was then fully committed. It still regarded it as necessary to use the commercial banks as a vehicle for achieving policy objectives, such as promoting small and medium-sized enterprises and establishing strategic industries. ${ }^{22}$ The pressure for financial liberalization was increasing, however, from both the chaebol that saw the advantage of having easy access to the global capital market through their NBFIs and the foreign financial interests that saw profitable opportunities in investing in the booming Korean economy. Under such unyielding pressures the government undertook financial reform, giving in where pressure was strong and holding back where it was not (Cho 2003). Given that NBFIs' activities were mainly in short-term transactions whereas those of the commercial banks were in longer-term maturities, the unbalanced financial opening was an inevitable outcome of the interest politics of financial reform.

\section{Chaebol reaping the benefits of liberalization}

While financial liberalization - both external and internal - gave more freedom to the chaebol in their search for financing, the government's ability to control them and curb their highly concentrated economic power was substantially reduced from 1993. For instance, in 1993 the creditceiling scheme - the last stick that the government had over the chaebolwas modified, exempting from the ceiling the affiliated companies that were in the chaebol's chosen areas of specialization. Furthermore, the number of the chaebol to which the ceiling applied was reduced from the top 50 to the top 30 in 1993 and was further reduced to the top ten in 1996. Restrictions on the holding of non-business-related land and the debt structure were also abolished. The ceiling on the ownership of bank shares was also raised in 1994, allowing more shares to be purchased by the chaebol, and in 1996 they were given more freedom with respect to the ownership of NBFIs. Although the government also made an effort to introduce stricter rules regarding cross-debt guarantees, cross-shareholdings, insider trading, the role of the board of directors, and the rights of minority shareholders, it failed to translate its effort into laws.

One of the consequences of the financial reforms undertaken during the 1990s was the increasing autonomy of the chaebol from the state as they became less dependent on the government-controlled commercial banks. This autonomy was further strengthened by the chaebol's ownership of NBFIs and their freer access to international capital, as discussed above.

The chaebol, perhaps the most powerful interest group in Korea, certainly played a role in getting rid of regulations such as the ceiling on their ownership of bank shares, the limit on foreign borrowing, and the ceiling on aggregate credit, as they saw it was to their own advantage to remove such regulations. But it also needs to be pointed out that when deregulation 
served their own material interests the chaebol could appeal to the neoclassical free-market paradigm that had become dominant in Korea's political economy since the early 1980s (Kong 2000).

\section{Concluding remarks}

There is no question at all that the economic crisis of 1997-98 provided the impetus necessary for the Korean government to restructure the economy. It has undertaken various measures to achieve macroeconomic stability, introduce transparency and accountability in corporate governance, liberalize further the trade and capital accounts, and reform the financial sector. To improve corporate governance, for instance, measures were introduced to place external directors on the board, strengthen the position of small shareholders, and require chaebol affiliates to combine their financial statements and stop credit guarantees among them (Jung 2002). Although the restructuring was done under International Monetary Fund (IMF) auspices and caused a severe economic hardship and popular resentment, it was not like being forced to establish alien institutions in Korea, as the IMF programme that Korea had to follow was not fundamentally different from the government's policy stance of the preceding two decades (Jwa 2001, ch. 9; Kong 2000, ch. 6).

The crisis put most of the financial institutions in a desperate situation and led to a reduction in the number of banks from 33 to 23 by the end of 1999. It also forced the government to establish two state-owned corporations, the Korea Asset Management Corporation (KAMCO) and the Korea Deposit Insurance Corporation (KDIC), to clean up the nonperforming loans and strengthen the capital base of the banks. The funds spent by those corporations reached about $\$ 128$ billion (at the exchange rate of 1,200 Korean Won to one U.S. dollar), 29 percent of Korea's GDP in 2000, as of September 2001. Although this injection of public funds into the banking system resulted in de facto nationalization of the banking system, that did not mean that the Korean financial system had reverted to the system established by the military government in 1961. It was only an exigent measure with no far-reaching consequence on the fundamental course that Korea charted out for its political economy in the early 1980s the establishment of a liberal market economy.

The nation's commitment to that goal was reaffirmed soon after the crisis by President Kim Dae-jung, who used the post-crisis financial reforms as an instrument to "put an end to the previous system of governmental control and to guarantee the greatest possible degree of autonomy for the management of financial institutions" (Kim 1999, 50). As he saw it, Korea's future lay in the establishment of a genuine and open market economy and there was no going back to the state-led growth model of the earlier years, whatever its merits might have been then.

Korea's post-crisis financial restructuring is the culmination of a long 
drawn-out reform process that started in 1980 when there was a paradigm shift in political economy in Korea. In the course of that process, powerful interest groups tried to and did in fact influence the outcome of reforms for the benefit of their own parochial interests; however, there appears to have been no dispute over the end state of that process - the establishment of a liberal economic order (Choi 1987). Even those who criticize the post-crisis reforms as a failure say that the reason for the failure is a premature dismantling of the state-led growth model and not the final goal of the reforms, which is to establish a liberal market economy (Crotty and Lee 2001).

Korea has now fully recovered from the crisis of 1997-98, and its economy has grown much more rapidly since 1999 than Japan's economy. Thus the short-term prospects for the Korean economy look better than those for the Japanese economy. But there still remains the question of whether the ready adoption of a liberal economic order will in the long run turn out to have been the right choice for Korea. ${ }^{23}$ As Lin and Nugent $(1995,2362)$ pointed out after an extensive review of the literature on institutions and economic development, formal institutions imported from abroad may not function effectively or, worse, may even be a source of social conflict, if they are not compatible with the country's indigenous institutions. It may turn out that the imported institutions are not effective in Korea due to their incompatibility with Korean culture and tradition, whereas Japan may eventually find its own system of political economy rooted in its culture and tradition although it will have paid a cost in the short run while searching for it.

According to North (1998), "most societies throughout history got 'stuck' in an institutional matrix that did not evolve into the impersonal exchange essential to capturing the productivity gains that came from the specialization and division of labor that have produced the Wealth of Nation." If this observation of North's is correct, Japan's search for a new political economy compatible with its culture and tradition but also suited to a global world economy will be a difficult one, as such a system requires a harmonious merging of what appear to be two incompatible opposites social exchange (a mode of exchange based on long-term unspecified obligations on the part of participants) and impersonal exchange on a global scale. ${ }^{24}$ Some societies, as pointed out by Platteau (2000), do undertake profound changes in institutions when faced with new economic opportunities and constraints imposed by economic and political forces. Given what Japan has done in importing and adopting alien institutions to its advantage in its modern history, we should feel confident that Japan is one such society. ${ }^{25}$ The question nevertheless remains as to whether endogenous changes in institutions will take place in Japan before it slides into a deeper economic crisis. 


\section{Acknowledgments}

The author wishes to thank Magnus Blomström, Lonny Carlile, Sun-Ki Chai, Young Back Choi, Sumner La Croix, Keun Lee, and James Mak, and participants in the conference on "Institutional change in Japan: Why it happens, Why it doesn't," January 5-6, 2003 for their comments on an earlier version of the paper.

\section{Notes}

1 Implicit in this argument is the assumption that the markets will work efficiently on their own once the government is taken out of them. But, as remarked by North $(2001,408)$, that assumption is a "lot of nonsense" since the removal of government does not guarantee that market competition will take place in a socially desirable way.

2 These three reasons imply that Japan will not undertake institutional reforms until it ceases to be a "rich" country, which may take a long time. But, according to Olson (1982), it will take more than a country's ceasing to be rich for it to undertake such reforms, as it needs to have an educated public who will see the necessity to "repeal all special-interest legislation or regulation and at the same time apply rigorous anti-trust laws" (p. 236).

3 Other reasons offered by Lincoln are, to quote, belief in the value of the existing system, interconnected nature of the distinctive features of the existing system, and a weak process of deregulation and administrative reforms.

4 Sato (1999) also notes that the current situation in Japan calls for a systemic change as fundamental and momentous as the 1868 Meiji Restoration and the 1945 postwar reform, but unlike the two historical cases the current change will have to be driven by internal forces and thus will be very difficult to achieve.

5 Yoon Hyung Kim (1994) uses the term the Korean model of political economy and predicts that Korea's new political economy will be in conformity with its cultural values. Italics added.

6 North (1999) points out that Marx and Engels provided the ideological foundation, a "belief system," for Lenin's revolution in the war-torn Russia of 1917. We might speculate whether the Russian revolution would have taken place if there had not been the belief system created by Marx and Engels. We should note that one reason why institutional changes took place rapidly in Eastern and Central Europe after the collapse of the Soviet Union is that the transition economies were modeling their reforms after the Western capitalistic system and not searching for a "third model."

7 Kuhn (1962) defines paradigms as "universally recognized scientific achievements that for a time provide model problems and solutions to a community of practitioners" (p. x). Here I use the term as a conception of the economy held by a majority of the people in that economy. In that sense it is close to "weltanschauung."

8 McCormack (1996) depicts the Japan of the early 1960s as a nation in search of its own identity, as in the following quote: "In Japan, the quest for wealth and power, and for equality of status with the West, launched in the late nineteenth century, has clearly been accomplished. But what has the century of striving meant? And what is there now to take its place as a focus for national endeavor? Both the historical and the political questions are bound to exercise many minds in the years ahead" (p. 153).

9 Clague (2002) notes that the timing of the reforms undertaken in less- 
developed countries of the world between the early 1960s and the late 1990s coincided with a change in the ideological climate in those countries. In her detailed study of the evolution of property rights in Kenya, Ensminger (1992) points out that the notions that people held about fairness and justice as well as purely economic considerations influenced the change from common to more restrictive property rights among the Orma in the 1980s.

10 Ensminger (1992) also reaches a similar conclusion in her study of institutional changes among the Orma. To quote (p. 180), "[t]he speed and success of their economic transition are controlled not just by technological innovation, the adoption of new governmental institutions, and entrepreneurial ingenuity, but also by the process by which new institutions are legitimized" (italics added).

11 Lincoln (2001) argues that the Japanese economic system is, in fact, different from the American economic system, a difference due to differences in their social norms and behavior.

12 Flath (2000, ch. 9), for example, argues that the reputation of Japan's industrial policy owes to the mere fact that the postwar period of Japanese economic success happened to coincide with the years when the Ministry of International Trade and Industry (MITI) was a powerful government ministry!

13 Another term for such networks is social capital. Putnam (1993) identifies social capital as involving networks, norms, and social beliefs that evolve out of processes that are not overtly investment activities. An investment made in building trust and reciprocity is an investment in building social capital.

14 Hayami (1998) described the Japanese system as a nexus of pseudo-community organizations, which has evolved through serious conflicts, compromises and syntheses between the traditional value system and the imitated Western institutions and organizations.

15 In social exchange, unlike in economic exchange, the obligations incurred in exchange are not clearly specified in advance. Social exchange requires trusting others (and in turn creates trust), and benefits from social exchange are less detachable from the source that supplies them than are economic commodities (Blau 1968).

16 It should be noted here that by liberalism Murakami (1996) meant a variant of liberalism unique to Japan and not the "classical economic liberalism."

17 Obviously the meaning of the "Japanese spirit" is neither immutable nor wholly agreed upon even by the Japanese. According to Westney $(1987,24)$, Meiji reformers redefined Japanese "tradition" to find a fit between the imported new institutions and their social environment. The same process of redefinition will probably take place with respect to the "Japanese spirit" if the current economic crisis continues, making the exigencies of institutional reform more manifest.

18 Patrick $(1999,69)$ finds no surprise in Japan's not having a navigational chart for its future since it has caught up with the leading nations of the West and since none of them has a "clear vision of its desired future 50 years hence" either. But it should be pointed out that an important difference between Japan and those nations is that in the case of Japan the prolonged economic malaise has prompted many to question the viability of what they regard as a unique political economy based on their deep-rooted culture and tradition, whereas in the other nations any change in the system is viewed as a minor doctoring within the existing paradigm.

19 According to Cho $(1994,29)$, the Japan that President Park Chung Hee took as a model for economic development was the Meiji Japan of the late nineteenth century. For example, Park followed the Meiji slogan for promoting a strong economy and a strong military, encouraging the rapid development of big corporations as a means of achieving a strong economy. 
90 Chung H. Lee

20 Williamson and Haggard (1994) point out that during the 1980s there occurred a profound change in the intellectual climate in the West toward what is now commonly called neoliberalism, and it had a powerful influence on policy reform in many developing countries.

21 This section draws heavily on Lee et al. (2002).

22 The Ministry of Finance and Economy supervised long-term foreign capital transactions, while the Bank of Korea had jurisdiction over short-term foreign capital inflows, and the latter reportedly had a greater predilection toward financial liberalization than the former.

23 Jung (2002) questions whether the new system of political economy will be successful in Korea. As he sees it, Korea has the cultural heritage of a centralized state system and an egalitarian value system, and that heritage is incompatible with a "neo-liberal governance model."

24 Hayami (2001) argues that although Japan is a society of "limited-group morality," it has been able to enforce informal contracts beyond a single community, a limited group, and thus extend economic exchange to other communities through its "multi-stranded nexus of communities." It is through this mechanism, according to Hayami, that Japan has been able to reap the benefit of extended market exchange, which is attributed in the West to its "generalized morality."

25 According to Lincoln (2001), the new system that will emerge in Japan will be different from that of the past 50 years but will be still more "constrained" than that in the United States or Europe.

\section{Bilbiography}

Amsden, Alice, Asia's Next Giant: South Korea and Late Industrialization, Oxford University Press, New York, 1989.

_ "The Specter of Anglo-Saxonization is Haunting South Korea" in Lee-Jay Cho and Yoon Hyung Kim (eds), Korea's Political Economy: An Institutional Perspective, Westview Press, Boulder, 1994.

Befu, Harumi, "Nationalism and Nihonjinron" in H. Befu (ed.), Cultural Nationalism in East Asia: Representation and Identity, Research Papers and Polity Studies, Institute of East Asian Studies, University of California, Berkeley, 1993.

Blau, Peter M., "Social Exchange" in David Sills (ed.), International Encyclopaedia of the Social Sciences, Vol. 7, Crowell, Collier \& Macmillan, New York, 1968.

Carlile, Lonny E. and Tilton, Mark C., "Regulatory Reform and the Developmental State" in L. E. Carlile and M. C. Tilton (eds), Is Japan Really Changing Its Ways? Brookings Institution Press, Washington, DC, 1998.

Cho, Lee-Jay, "Culture, Institutions, and Economic Development in East Asia" in Lee-Jay Cho and Yoon Hyung Kim (eds), Korea's Political Economy: An Institutional Perspective, Westview Press, Boulder, 1994.

— Kim, Yoon Hyung and Lee, Chung H. (eds), Restructuring the National Economy, Korea Development Institute, Seoul, 2001.

Cho, Yoon Jai, "Financial Liberalization and Crisis in Korea" (in Korean), Bank of Korea Report, No. 99-3, Seoul, Korea, 1999.

"The Political Economy of the Financial Liberalization and Crisis in Korea" in C. H. Lee (ed.), Financial Liberalization and the Economic Crisis in Asia, Routledge, London, 2003.

Choi, Byung-Sun, "Institutionalizing a Liberal Economic Order in Korea: The Strategic Management of Economic Change," Ph.D. Dissertation, Harvard University, Cambridge, 1987. 
"Financial Policy and Big Business in Korea: The Perils of Financial Regulation" in S. Haggard, C. H. Lee, and S. Maxfield (eds), The Politics of Finance in Developing Countries, Cornell University Press, Ithaca, 1993.

Clague, Christopher, "The Political Economy of Economic Liberalization: Analytical Approaches from Economics and Political Science" in S. Grossbard-Shechtman and C. Clague (eds), The Expansion of Economics: Toward a More Inclusive Social Science, M. E. Sharpe, Armonk, NY, 2002.

Crotty, James and Lee, Kang-Kook, "Economic Performance in Post-Crisis Korea: A Critical Perspective on Neoliberal Restructuring," Seoul Journal of Economics, Vol.14, No. 2, Summer 2001, 183-242.

Dale, Peter N., The Myth of Japanese Uniqueness, Croom Helm, London, 1986.

Denzau, Aruther T. and North, Douglass C., "Shared Mental Models: Ideologies and Institutions," Kyklos, Vol. 47, 1994, Fasc. 1, 3-31.

Dower, John W., Embracing Defeat: Japan in the Wake of World War II, W. W. Norton, New York, 1999.

Edwards, Sebastian, The Economics and Politics of Transition to an Open Market Economy: Columbia, OECD Development Centre, Paris, 2001.

Ensminger, Jean, Making a Market: The Institutional Transformation of an African Society, Cambridge University Press, Cambridge, 1992.

Fairbank, John K., Reischauer, Edwin O., and Craig, Albert M., East Asia: The Modern Transformation, Houghton Mifflin, Boston, 1965.

Flath, David, The Japanese Economy, Oxford University Press, Oxford, 2000.

Gyohten, Toyoo, "Scholars, Go Back to Your Campus," 2000. Online. Available at: www.glocom.org/opinions/essays/200104. Accessed 2001.

Hayami, Yujiro, "Toward an East Asian Model of Economic Development" in Y. Hayami and M. Aoki (eds), The Institutional Foundations of East Asian Economic Development, St. Martin's Press, New York, 1998.

- Development Economics: From the Poverty to the Wealth of Nations, 2nd edition, Oxford University Press, Oxford, 2001.

Hodgson, Geoffrey M., Economics and Utopia, Routledge, London, 1999.

Jung, Ky-hyun, "Can the Old and New Economies Coexist?" in The Challenges of Reconciliation and Reform in Korea, Korea Economic Institute of America, Washington, DC, Vol. 12, 2002.

Jwa, Sung-Hee, A New Paradigm for Korea's Economic Development: From Government Control to Market Economy, Palgrave, London, 2001.

Kim, Dae-jung, "Toward a Parallel Pursuit of Democracy and a Market Economy," Republic of Korea Economic Bulletin, Vol. 21, No. 3, March 1999.

Kim, Kihwan, "Kim Jae-Ik: His Life and Contributions" in Lawrence B. Krause and Kim Kihwan (eds), Liberalization in the Process of Economic Development, University of California Press, Berkeley, 1991.

Kim, Pyung Joo, "Financial Institutions" in Lee-Jay Cho and Yoon Hyung Kim (eds), Korea's Political Economy: An Institutional Perspective, Westview Press, Boulder, 1994.

Kim, Yoon Hyung, "An Introduction to the Korean Model of Political Economy" in Lee-Jay Cho and Yoon Hyung Kim (eds), Korea's Political Economy: An Institutional Perspective, Westview Press, Boulder, 1994.

Knight, Jack, Institutions and Social Conflict, Cambridge University Press, Cambridge, 1992. 
92 Chung H. Lee

Kong, Tat Yan, The Politics of Economic Reform in South Korea: A Fragile Miracle, Routledge, London, 2000.

Kuhn, Thomas S., The Structure of Scientific Revolutions, University of Chicago Press, Chicago, 1962.

La Croix, Sumner, "Economic Reform in Japan: Why It Happens, Why It Doesn't" in Fixing Japan's Economy, Japan Information Access Project, Washington, DC, April 8, 2002.

— and Mak, James, "Regulatory Reform in Japan: The Road Ahead" in M. Blömstrom, B. Gangnes and S. La Croix (eds), Japan's New Economy: Continuity and Change in the Twenty-First Century, Oxford University Press, Oxford, 2001.

Lee, Chung H., "The Government, Financial System, and Large Private Enterprises in the Economic Development of South Korea," World Development, February 1992, Vol. 20, No. 2, 187-97.

__ Lee, Keun, and Lee, Kangkook, "Chaebols, Financial Liberalization and Economic Crisis: Transformation of Quasi-Internal Organization in Korea," Asian Economic Journal, Vol. 16, No. 1, January 2002, 17-35.

Lin, Justin Yifu and Nugent, Jeffrey B., "Institutions and Economic Development" in J. Behrman and T. N. Srinivasan (eds), Handbook of Development Economics, Vol. III, Elsevier Science B.V., Amsterdam, 1995.

Lincoln, Edward J., Arthritic Japan: The Slow Pace of Economic Reform, Brookings Institution, Washington, DC, 2001.

McCormack, Gavan, The Emptiness of Japanese Affluence, M. E. Sharp, Armonk, 1996.

Moon, Chung-in, "Changing Patterns of Business-Government Relations in South Korea" in Andrew MacIntyre (ed.), Business and Government in Industrialising Asia, Allen \& Unwin, St. Leonards, NSW, 1994.

Morishima, Michio, Why has Japan 'succeeded'? Western technology and the Japanese ethos, Cambridge University Press, Cambridge, 1982.

__ "Why do I Expect Japan to Collapse?" in Craig Freedman (ed.), Why Did Japan Stumble? Causes and Cures, Edward Elgar, Cheltenham, 1999.

Murakami, Yasusuke, "The Japanese Model of Political Economy" in K. Yamamura and Y. Yasuba (eds), The Political Economy of Japan, Vol. 1, The Domestic Transformation, Stanford University Press, Stanford, 1987.

— An Anticlassical Political-Economic Analysis, Stanford University Press, Stanford, 1996.

and Rohlen, Thomas R., "Social-Exchange Aspects of the Japanese Political Economy: Culture, Efficiency, and Change" in S. Kumon and H. Rosovsky (eds), The Political Economy of Japan, Vol. 3, Culture and Social Dynamics, Stanford University Press, Stanford, 1992.

North, Douglass C., "Economic Performance through Time" in M. C. Brinton and V. Nee (eds), The New Institutionalism in Sociology, Russell Sage Foundation, New York, 1998.

_ Understanding the Process of Economic Change, Occasional Paper 106, Institute of Economic Affairs, London, 1999.

_ "Comments" in M. Aoki and Y. Hayami (eds), Communities and Markets in Economic Development, Oxford University Press, Oxford, 2001.

Okimoto, Daniel I., Between MITI and the Market: Japanese Industrial Policy for High Technology, Stanford University Press, Stanford, 1989. 
Olson, Mancur, The Logic of Collective Action, Harvard University Press, Cambridge, 1971.

- The Rise and Decline of Nations: Economic Growth, Stagflation, and Social Rigidities, Yale University Press, New Haven, 1982.

Organization for Economic Cooperation and Development (OECD), Regulatory Reform in Korea, OECD, Paris, 2000.

Park, Yung Chul, "Korea: Development and Structural Change of the Financial System" in H. T. Patrick and Y. C. Park (eds), The Financial Development of Japan, Korea, and Taiwan, Oxford University Press, New York, 1994.

Patrick, Hugh, "Rumination on Morishima" in Craig Freedman (ed.), Why Did Japan Stumble? Causes and Cures, Edward Elgar, Cheltenham, 1999.

Platteau, Jean-Philippe, Institutions, Social Norms, and Economic Development, Hardwood Academic Publishers, Amsterdam, 2000.

Porter, Michael E., Takeuchi, Hirotaka, and Sakakibara, Mariko, Can Japan Compete? Perseus Publishing, Cambridge, 2000.

Putnam, Robert D., Making Democracy Work: Civic Traditions in Modern Italy, Princeton University Press, Princeton, 1993.

Sakakibara, Eisuke, Beyond Capitalism: The Japanese Model of Market Economy, University Press of America, Lanham, 1993.

Sato, Kazuo, "Japan at a Crossroads" in K. Sato (ed.), The Transformation of the Japanese Economy, M. E. Sharpe, Armonk, 1999.

— "From Fast to Last: The Japanese Economy in the 1990s," Journal of Asian Economics, Vol. 13, No. 2, March/April 2002, 213-35.

Streeck, Wolfgang and Yamamura, Kozo (eds), The Origins of Nonliberal Capitalism: Germany and Japan in Comparison, Cornell University Press, Ithaca, 2001.

Wade, Robert, Governing the Market: Economic Theory and the Role of Government in East Asian Industrialization, Princeton University Press, Princeton, 1990.

Westney, D. Eleanor, Imitation and Innovation: The Transfer of Western Organizational Patterns to Meiji Japan, Harvard University Press, Cambridge, 1987.

Williamson, John (ed.), The Political Economy of Policy Reform, Institute for International Economics, Washington, DC, 1994.

Williamson, John and Haggard, Stephan, "The Political Conditions for Economic Reform" in J. Williamson (ed.), The Political Economy of Policy Reform, Institute for International Economics, Washington, DC, 1994.

Williamson, Oliver, Markets and Hierarchies: Analysis and Antitrust Implications, Free Press, New York, 1975.

Woo, Jung-En, Race to the Swift, Columbia University Press, New York, 1991.

Yamazawa, Ippei, "Comments" in L.-J. Cho, Y. H. Kim, and C. H. Lee (eds), A Vision for Economic Cooperation in East Asia: China, Japan, and Korea, Korea Development Institute, Seoul 2003. 



\section{Part II}

\section{Japanese institutions}

What has changed, what has not, and why 



\section{A lost decade for Japanese corporate governance reform?

\author{
What has changed, what hasn't, and \\ why
}

Curtis J. Milhaupt

\section{Introduction}

The more things change, the more they remain the same. Or so it seems with Japanese corporate governance. Over the past decade, the formal institutional environment for Japanese corporate governance has been reformed significantly and at an accelerated pace. In response, some important new trends in corporate practice may be developing. Yet despite substantial legal reform and a decade after Japan's economic problems emerged, there has been no sea change in Japanese corporate governance practices. To adopt a metaphor favored in new institutional economics literature, the rules of the game have changed; whether the play of the game will change, however, is still an open question.

In this chapter, I seek to answer three questions about institutional transformation in the context of Japanese corporate governance: What has changed, what hasn't, and why? Answers to these questions should provide at least some tentative insights into the central issue - has it been a "lost decade" for Japanese corporate governance reform?

The chapter is structured as follows: The first part briefly surveys the major trends in corporate law reform over the past decade, emphasizing the magnitude and pace of formal institutional change in this area. The second part examines corporate practices that have changed in response to the new institutional environment, and conversely, key areas of stickiness in Japanese corporate practices. The third part attempts to provide an explanation for this pattern of change and non-change.

Revealing the conclusion at the outset, it has not been a lost decade for Japanese corporate governance reform. Indeed, the formal institutional environment for corporate governance today is significantly more flexible and conducive to shareholder wealth maximization ${ }^{1}$ than it was in the early 1990s. And there are important, if tentative, signs that the new environment is actually facilitating new forms of corporate finance, alternative organizational structures and more diverse business practices. But the new institutional package is a necessary, not a sufficient, condition for fundamental corporate governance reform. Dynamics external to the 
formal corporate governance system narrowly defined - such as capital market developments and new trends in the dispersion and identity of shareholders - must animate the new institutional arrangement. Even "perfect" corporate law has limits (Roe 2003): it can help facilitate, but not guarantee, good corporate governance. After a decade of legal reform, Japan now has pretty good corporate law. ${ }^{2}$ The question for the coming decade is whether actors will utilize that law as a framework on which to build a new set of good corporate governance practices.

\section{A sea change decade for Japanese corporate law}

The past ten years can fairly be called a "sea change decade" for Japanese corporate law. For reasons that will be explored in detail below, the decade witnessed the most sweeping and fast-paced amendments to the corporate law (found principally in the Commercial Code) since its enactment a century ago (see e.g. Kanda 2000). Table 4.1 lists the major amendments to the Code and related laws over the years 1993-2002.

These amendments can be placed into two groups. One group might be called flexibility enhancing amendments. These Code changes expand corporate finance options and increase organizational flexibility for Japanese firms in the areas of mergers, divestitures, and reorganizations. A second group might be called monitoring enhancing amendments. These Code amendments include changes to the shareholder derivative suit mechanism $^{3}$ and statutory auditor system as well as reforms to the corporate board structure. A brief survey of these two groups of amendments follows.

Table 4.1 Major Commercial Code amendments 1993-2002

\begin{tabular}{|c|c|}
\hline & Commercial Code Amendments \\
\hline \multirow[t]{3}{*}{1993} & Fixing fee of 8200 yen for shareholder derivative suits \\
\hline & Introducing a board of statutory auditors (kansayakukai) \\
\hline & Reducing shareholding threshold to demand inspection of records \\
\hline 1994 & Deregulating limitations on repurchase of shares (1) \\
\hline \multirow[t]{2}{*}{1997} & $\begin{array}{l}\text { Introducing stock option system (Deregulating limitations on } \\
\text { repurchase of shares [2]) }\end{array}$ \\
\hline & Simplifying merger procedures \\
\hline 1998 & Deregulating limitations on repurchase of shares (3) \\
\hline 1999 & Creating share exchange system \\
\hline 2000 & Creating company spin-off system \\
\hline \multirow{4}{*}{2001} & Lifting ban on treasury stock \\
\hline & Creating new stock acquisition right (shin kabu yoyaku ken) system \\
\hline & Expanding the authority of statutory auditors \\
\hline & Authorizing limitations on managers' liability \\
\hline 2002 & $\begin{array}{l}\text { Creating an option to form committees of the board of directors in lieu } \\
\text { of the statutory auditor system }\end{array}$ \\
\hline
\end{tabular}




\section{Flexibility enhancing amendments}

\section{Stock options}

Beginning in 1997, the Commercial Code formally authorized the issuance of stock options to certain firm employees (though more thorough liberalization required several additional amendments in ensuing years). ${ }^{4}$ Liberalization of the stock option regime provides flexibility in employee compensation schemes. It also contributes to the enhancement of monitoring, by helping to align the incentives of managers and shareholders. As a percentage of total compensation, variable pay increased from 21 percent to 33 percent from 1996 to 2003, and the portion of variable pay consisting of stock options went from zero to 20 percent over that period (Towers Perrin 2003).

\section{Mergers}

Also in 1997, merger procedures were liberalized, eliminating individual creditor notifications and permitting short-form mergers, whereby shareholder approval is not required if the parent already owns most of the target company's stock. ${ }^{5}$

\section{Share-for-share exchanges and holding companies}

The Commercial Code was revised in 1999 to introduce share-for-share exchanges. ${ }^{6}$ This was a response to the abolition, in 1997, of the AntiMonopoly Law's ban on holding companies. Share exchanges can be used to create wholly owned subsidiaries in a holding company structure, and to enable companies to use their shares as acquisition currency to take a partially owned subsidiary private or to acquire an unrelated company. Capital gains taxes are not owed at the time of the share exchange. Timeconsuming and expensive valuation procedures to protect creditors mandated by the Commercial Code for ordinary mergers are not required. Minority shareholders can be forcibly excluded from the subsidiary (although they become shareholders of the parent).

Eliminating the prohibition on holding companies could have several important benefits for Japanese firms (see Aoki 2000, 133-40). Most basically, it will promote spin-offs, mergers, and corporate reorganizations. But it will also provide useful legal separation between strategic and operating units of the firm, and allow firms to differentiate personnel management systems. Firms may retain conventional "Japanese" employment patterns where useful, while introducing more diverse arrangements in other subsidiaries. For financial institutions, removal of the ban on financial holding companies facilitates reorganization of the financial industry into functionally diverse groups offering banking, securities, and insurance products and services. 
100 Curtis J. Milhaupt

Spin-offs and split-offs

In 2000, a new statutory scheme provided a flexible framework for separating business units from parent companies. ${ }^{7}$ Prior to the amendment, divestitures were extremely cumbersome, because corporate transfers of liabilities and assets required individual approval of creditors and courtsupervised valuations, respectively.

\section{Corporate finance}

A variety of amendments and special statutes over the past decade have effectively eliminated the prohibition against redemption of a company's outstanding shares and expanded the forms of equity securities (such as tracking stock and other classified shares) that a firm is permitted to issue. ${ }^{8}$ Share buybacks can be used to distribute cash to shareholders and are useful in a variety of corporate recapitalization schemes; the liberalization of equity securities provides greater flexibility in corporate finance techniques.

\section{Corporate reorganizations}

A Civil Rehabilitation Act, enacted in 2000 and modeled loosely on the U.S. Chapter 11 regime, provides more flexible and efficient reorganization procedures than its predecessor statute. In a major departure from past reorganization procedures in Japan, the Civil Rehabilitation Act is a debtor-in-possession system (meaning that existing management, rather than a court-appointed trustee, operates the firm during the rehabilitation process and devises a rehabilitation plan). Passage of the rehabilitation plan only requires approval by a majority of qualifying creditors. It is now possible to do a "prepackaged" bankruptcy, with the reorganized firm emerging under new ownership. ${ }^{9}$

\section{Monitoring enhancing amendments}

\section{Shareholder derivative suits}

Until 1993, most Japanese courts required plaintiffs in shareholder derivative suits to pay a filing fee on a sliding scale based on the amount of damages sought. Under this scale, in dollar terms a \$10 million claim against management, for example, would require a filing fee of $\$ 25,000-\mathrm{a}$ fee that was forfeited if the plaintiffs lost (West 2001a). The 1993 amendment fixed the filing fee at the nominal sum of 8,200 yen (about $\$ 80$ ), eliminating a major barrier to this form of shareholder monitoring. In the same set of amendments, the required minimum shareholding to inspect corporate books and records was reduced from 10 percent to 3 percent. 
Practically, however, this threshold is still too high to be meaningful for purposes of bringing suit against management or the exercise of other shareholders' rights, since most shareholders at the 3 percent level are friendly, stable shareholders. ${ }^{10}$

\section{Reforms to statutory auditory system}

Japanese corporate law has a German-inspired institution known as the statutory auditor (kansayaku), whose basic function is to monitor the board's compliance with law and the certificate of incorporation. Over the past decade, several reforms were made to this corporate organ. Amendments in 1993 mandated that large companies have at least three auditors, functioning as a board of audit. ${ }^{11}$ In 2001, amendments sought to strengthen the auditor regime by extending the term of office and responsibilities of auditors, while increasing the required number and qualifications of outside auditors. ${ }^{12}$ As of 2005 , at least half of the board of audit must be comprised of outside auditors.

\section{Board reforms}

A major overhaul of the Commercial Code in 2002 allows firms to opt out of the statutory auditor system in favor of a U.S.-style "committee system" for corporate governance. ${ }^{13}$ In lieu of statutory auditors, firms can establish board committees for the audit, nomination and compensation functions. A majority of the members of each committee must be independent. A 2001 amendment creates a formal distinction between directors, bearing oversight responsibility but not day-to-day managerial functions, and executive officers who actually run the firm. ${ }^{14}$ These reforms are designed to strengthen the supervisory role of the board and to enhance the separation of monitoring and decision-making functions.

\section{Accounting reforms}

Japanese accounting standards have been revised significantly in the past several years to bring them substantially into conformity with international accounting standards. Cash flow statements were introduced in fiscal year 1999, and rules on consolidated accounting were tightened in that year. Mark-to-market accounting for financial assets was introduced in fiscal year 2001. As of fiscal year 2001, pension liabilities must be reflected on balance sheets. The new rules enhance management transparency and provide powerful new incentives for restructuring or divesting under-performing assets, which no longer can be concealed by moving them into affiliated corporations. 


\section{An ambiguous decade for corporate practices}

Has this plethora of new formal rules for corporate finance, organization and governance changed the way Japanese firms are structured and managed? To date, the evidence on corporate governance change in Japan is ambiguous. While some data suggest meaningful responses to the new rule environment have occurred in several areas, there is little sign that Japanese corporate governance practices are being fundamentally transformed or are rapidly "converging" with those of the United States.

Although my primary aim here is simply to catalogue the areas of change and non-change, I hasten to emphasize the controversial nature of any measurement exercise in this field. Whether Japanese corporate law and governance practices need to be fundamentally reformed, and particularly whether they need to emulate U.S. corporate practices, remain controversial issues (on the first issue, see e.g. Miwa and Ramseyer 2003; on the second, see e.g. Osugi and Zaloom 2002). At the same time, however, some sort of baseline is needed against which to measure and evaluate reform. I use the U.S. corporate governance system for purposes of comparison, both because it is the principal competing model of corporate governance, and because the primary normative features (not always achieved, to be sure) of that model - transparency, managerial accountability, and adaptability - appear to have become de facto "global standards" in corporate governance.

\section{What's changed}

Signs of change can be found principally in the areas of shareholder activism, corporate mergers and other organizational changes, board structure, and corporate finance. Reinforcing and reflecting these changes are subtle shifts in "norms" about corporate governance in Japan.

\section{Shareholder activism}

The seemingly technical change in procedural law in 1993 that lowered the cost of filing derivative suits led to a major increase in this form of shareholder monitoring. Japanese shareholders brought a total of about 20 derivative suits between 1950 and 1990. By contrast, at least 494 derivative suits were filed between 1991 and 2000 (Milhaupt 2003). While the Japanese derivative suit mechanism suffers from the same attorney's-fee-based incentive distortions that plague such suits in the United States (West 2001a), this shift toward heightened shareholder monitoring may deter at least blatant forms of wrongdoing by managers, and places greater pressure on management to avoid actions that are per se destructive of shareholder value, such as refusing to sell portfolio shares held in a stable shareholding relationship to the highest bidder. Moreover, institutional 
investors, whose managers must answer to their own shareholders and beneficiaries, will likely face increased pressure to focus on financial returns from their portfolio investments. Recently issued Pension Fund Association Guidelines reinforce this trend. The Guidelines state that fund managers should evaluate disclosure, dividend policies and corporate governance in exercising shareholders' rights, and provide that fund managers should be evaluated on the exercise of shareholders' rights in addition to financial performance.

Greater resort to derivative litigation has also created new law clarifying the legal responsibilities of directors to their firms. The best example of this process is the Daiwa Bank litigation. In that case, shareholders of Daiwa Bank derivatively sued eleven current and former directors for failing to uncover and report to U.S. authorities massive unauthorized trading in the Bank's New York branch that ultimately resulted in almost $\$ 1.5$ billion in losses and fines. The directors, heeding a Ministry of Finance indication that disclosure of the losses to the Federal Reserve would be untimely given instability in the financial system, filed a misleading Call Report with the U.S. banking regulators, a violation of U.S. law. The Osaka District Court found the directors liable for breach of duty, and ordered them to pay about $\$ 775$ million in damages. The court shrugged off the directors' argument that the Ministry of Finance's conduct should insulate the directors from liability. The court found that the "defendant [directors] had persisted in following local rules that only apply in Japan, despite the fact that [the firm's operations] had expanded on a global scale."15 Through this and other decisions in derivative suits, the courts help to educate management about proper behavior with respect to their shareholders.

Although still extremely small in number, the past few years have also witnessed unprecedented (at least by Japanese standards) incidents of hostile mergers and acquisitions (M\&A) activity. For example, in 2000, a domestic takeover firm, M\&A Consulting, launched a hostile bid for Shoei Corporation, one of the first postwar hostile bids for a Japanese corporation by a Japanese corporation. M\&A Consulting followed this in 2002 with a proxy fight over dividend policies at a firm called Tokyo Style. Both attempts failed. However, when considered in combination with several successful, unsolicited bids by foreign firms such as Cable \& Wireless's acquisition of IDC and Boehringer Ingelheim's acquisition of a blocking stake (more than 33.3 percent of the shares) in SS Pharmaceuticals, it is fair to say that Japanese management is no longer fully secure from the threat of hostile acquisition or other unwelcome shareholder advances. More recently, Livedoor's bid for Nippon Broadcasting Corporation generated enormous controversy and sparked discussion of a possible wave of hostile acquisitions in Japan. The bid also lent momentum to a ministerial effort to create guidelines for hostile takeovers. This effort, quite remarkably, led to the promulgation of takeover standards heavily based on Delaware judicial doctrine (see Milhaupt 2005). 


\section{Curtis J. Milhaupt}

Separately, a nonprofit corporate reform organization known as Shareholder (Kabunushi) Ombudsman has also contributed to a more activist shareholder environment in recent years (see Milhaupt 2004). This organization has been involved in virtually all of the high-profile shareholder derivative litigation in Japan, and has reached large monetary settlements with management and commitments to institute procedures to prevent future wrongdoing at their firms. Although not a highly visible player in the Japanese corporate governance scene, Japanese managers ignore this activist organization at their peril.

\section{Mergers and organizational changes}

Friendly merger and acquisition activity in Japan has increased significantly in recent years. ${ }^{16}$ Although still small in comparison to deal activity in the United States, the increase in the number and size of transactions in recent years is striking.

Available measures show marked increases in the 1990s, as shown in Figure 4.1. ${ }^{17}$ Data from Recof $(2001,2002)$, which showed approximately 300 mergers and acquisitions of Japanese firms in 1991, reports 847 transactions in 1999, 1,241 in 2000, and 1,348 in 2001. Thomson Financial data show a significant increase in purely domestic ("in-in") M\&A. After averaging fewer than 100 transactions per year during 1990-94, with a gross average value of about $¥ 800$ billion ( $\$ 8$ billion), in-in M\&A reached about 1,400 transactions in 1999 , with a gross transaction value of $¥ 13$ trillion ( $\$ 130$ billion). The number of "out-in" transactions, which averaged only about 50 per year during $1990-94$, with a total average value of only $¥ 50$ billion ( $\$ 500$ million), increased to 227 transactions with a value of $¥ 3$ trillion ( $\$ 30$ billion) in 1999. Even in the first quarter of 2003, after a steep decline in worldwide M\&A activity, Japan ranked fifth in M\&A volume by deal value, with 444 deals valued at almost $\$ 20$ billion, up from 396 deals valued at $\$ 17.4$ billion in first quarter of 2002 (Mergers Shapshot 2003).

The increase in the Japanese M\&A market can also be seen relative to gross domestic product. In 1990, Japanese merger activity was approximately 0.4 percent of GDP. By 1999, Japanese merger activity was approximately 3.3 percent of GDP. In the ranking of targets by nation, Japan moved from a 0.6 percent market share in 1997 to a fifth-place 4.5 percent market share in 1999 (Thomson Financial, Merger Yearbook), and to 5.5 percent in the first quarter of 2002 (Thomson Financial 2002).

There are no data available on the specific legal mechanics of each deal. But some mergers, such as the giant Mizuho Financial Group alliance that combined Dai-Ichi Kangyo Bank, Fuji Bank, and the Industrial Bank of Japan, have used the new holding company structure. The newly established share exchange system also appears popular; one source lists 17 such transactions in 1999 and another 25 in the first six months of 2000, involving such firms as Sony, Matsushita, Isuzu, and Toyota (Kikuchi 2000, 


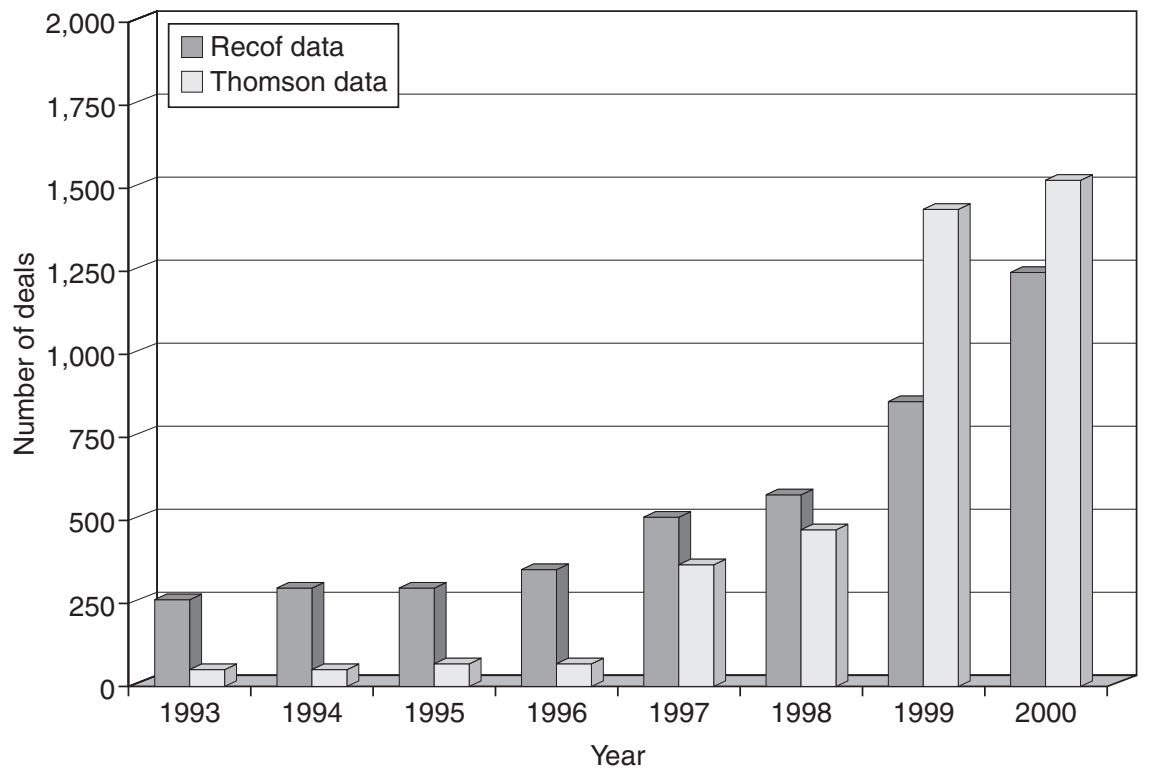

Figure 4.1 Number of deals involving Japanese targets, 1993-2000.

118-19). In the first fiscal year that spin-offs were legal, more than 200 such transactions occurred (Kaisha bunkatsu 2001), including several combinations that would have not been undertaken absent the change (Kaisha ha koshite henshin saseru 2002).

\section{Board and officer reforms}

In an effort to enhance the effectiveness of the board, in the mid-1990s many companies began to consider reducing the size of the board and including outside directors. Survey data show an increase in firms displaying particular interest in reducing the number of directors, from 28.6 percent to 46.2 percent from 1998 to 2000 (Tokyo shoken torihikijo 2000). Of the firms reducing their boards, 79.9 percent scaled back to fewer than ten directors. By May 2001, 38.8 percent of first-section Tokyo Stock Exchange firms had added outside directors to their boards (Shagai torishimariyaku $38 \%$ ga sennin 2001). Moreover, diversity of business backgrounds among board members is beginning to draw attention as a desirable distinguishing characteristic for Japanese firms (Diversity Distinguishes IY Bank 2001).

In concert with reductions in board size, many corporations added a new corporate governance organ discussed above, the executive officer. 


\section{Curtis J. Milhaupt}

As Milhaupt (2001) noted, executive officers went from being a Sony innovation in 1997 to a fixture at over 200 firms by 1999. Survey data confirm that 71.4 percent of responding firms had adopted such a mechanism (Shoji homu kenkyukai 1999).

\section{Share repurchases}

In 1998, following Commercial Code revisions, 1,179 companies announced share buybacks, and 186 implemented them in that year (Yasui 1999, 26; Zhang 2000). Buybacks by listed companies in fiscal 2001 exceeded 2.3 trillion yen (about $\$ 20$ billion) for more than two billion shares, an increase of nearly 100 percent over fiscal 2000 (Jisha kabu kai baizo, 2 cho encho 2002).

\section{Norm shifts}

The past decade has not only been a time of enormous formal institutional (legal) change in Japanese corporate governance, it has also been a time of informal institutional (normative) change. Norms are simply nonlegal rules - rules that are neither promulgated by an official source nor enforced through formal sanctions, yet are regularly complied with (Posner 1997). Major features of postwar Japanese corporate governance - the main bank system, the concomitant absence of an external market for corporate control, employee-dominated boards that focus on day-today management rather than monitoring, and the lifetime employment system - were all shaped and supported by social norms (Milhaupt 2001; Moriguchi and Ono, ch. 6 this volume). That is, the operation of these institutions was heavily influenced by shared expectations about how Japanese banks, firms, and their governmental regulators should operate.

Over the past decade, however, these expectations have been severely tested, if not shattered. It is apparent that significant norm shifts are under way in Japan: increased, if grudging, acceptance of the takeover (including hostile takeovers) as a legitimate tool of corporate strategy and monitoring, a heightened awareness of shareholders' economic expectations, a change in managerial mindset about its proper role in running the firm, diminished expectations of forbearance toward failing firms on the part of banks and their regulators, and rising ambivalence about the benefits of seniority-based employment practices (Milhaupt 2001). In this sense, along with the corporate law, the "informal" institutional environment for Japanese corporate governance has changed in a manner almost unthinkable a decade ago. Much of this environmental change, in turn, has taken place because of changes in formal institutions discussed above that have reduced the transaction costs of basic corporate activities such as engaging in mergers and acquisitions, filing a derivative suit, or conducting a corporate reorganization. As actors engage in these newly feasible activities, they 
undermine the continued validity of "cultural" explanations for Japanese corporate practices, and help create new expectations about how the world works.

\section{What hasn't changed}

Despite these considerable signs of new activity, a balanced assessment of the past decade must also highlight stasis in important areas of Japanese corporate governance. Despite the more flexible and shareholder-oriented formal framework provided by the corporate law, the managerialist and employee-oriented cast to the Japanese firm has not been fundamentally eroded. Despite predictions to the contrary (see Hansmann and Kraakman 2001), it is not evident that we are witnessing the "end of history for corporate law" brought on by a Japanese embrace of the U.S. shareholder-oriented model. In fact, a "market test" of the degree of convergence between Japanese and U.S. corporate governance is now possible, at least with respect to board structure. As noted above, as of April 2003, firms have the option of adopting a U.S.-style committee system with outside directors in lieu of the Japanese-style board of statutory auditors. Thus far, a relatively small number of Japanese firms have adopt the U.S. board structure featuring committees of independent directors, principally because few Japanese chief executives are willing to cede authority over important functions such as board nominations to outside directors. ${ }^{18}$

There are other examples of non-change in important areas. Japanese institutional investors, for example, remain relatively passive. Most such investors still place priority on maintaining reciprocal business relationships over increasing shareholder value. They vote, but rarely coordinate with other institutional investors on corporate governance issues, make shareholder proposals, release focus lists, or engage in other efforts to improve performance at portfolio firms (Akaishi 2002). To be fair, institutional investors in most countries are passive, and the corporate governance record of institutional investors in the United States is mixed. But even with these caveats, Japanese institutional investors to date seem hesitant to press management for improved performance, or to consider selling their shares in the face of a financially attractive offer.

Indeed, the initial forays into shareholder activism discussed in the previous section have sent a decidedly mixed message on the state of Japanese corporate governance. While the mere existence (however scant) of hostile takeovers and proxy fights is a sign of change, most of the early, purely domestic bids failed. And they failed in large part because banks and institutional investors gave unconditional support to existing management when the unwelcome bidder appeared (see e.g. Institutions Threaten Corporate Governance 2002).

As these episodes suggest, Japanese management is still somewhat insulated from market pressures, disabling a major force for new governance 


\section{Curtis J. Milhaupt}

adaptations. This impression is bolstered by the lack of market activity around firms that should be ripe for takeover. Figure 4.2 illustrates the ratio of bust-up value to market capitalization for 779 non-financial Tokyo Stock Exchange firms. As the figure indicates, as of 2000 approximately 13 percent of these firms were trading below their bust-up value..$^{19}$ In other words, more than one of every eight public firms in Japan in that year was worth more in liquidation than under current management. This situation per se is not unprecedented. Some U.S. firms traded below their bust-up values in the 1980s. In contrast to the U.S. situation, however, there is virtually no market action in Japan to dismantle these firms. Despite the obvious potential to profit by acquiring and then selling off the assets of these firms, bids are rare. Milhaupt and West (2003) argue that this situation is the result of transaction costs that outweigh profits from takeovers, due to poor disclosure practices, mandatory bid procedures that may increase the uncertainty of successfully obtaining a controlling stake in the target, and other obstacles.

Another important area of relative stasis is employment practices. Evidence to date indicates that lifetime employment remains a core feature of the Japanese firm, even if the number of workers enjoying its protection is shrinking. A 1999 survey indicates that a majority of companies plan to maintain the lifetime employment system; most are seeking to reduce employment through natural or incentivized attrition (Hisada et

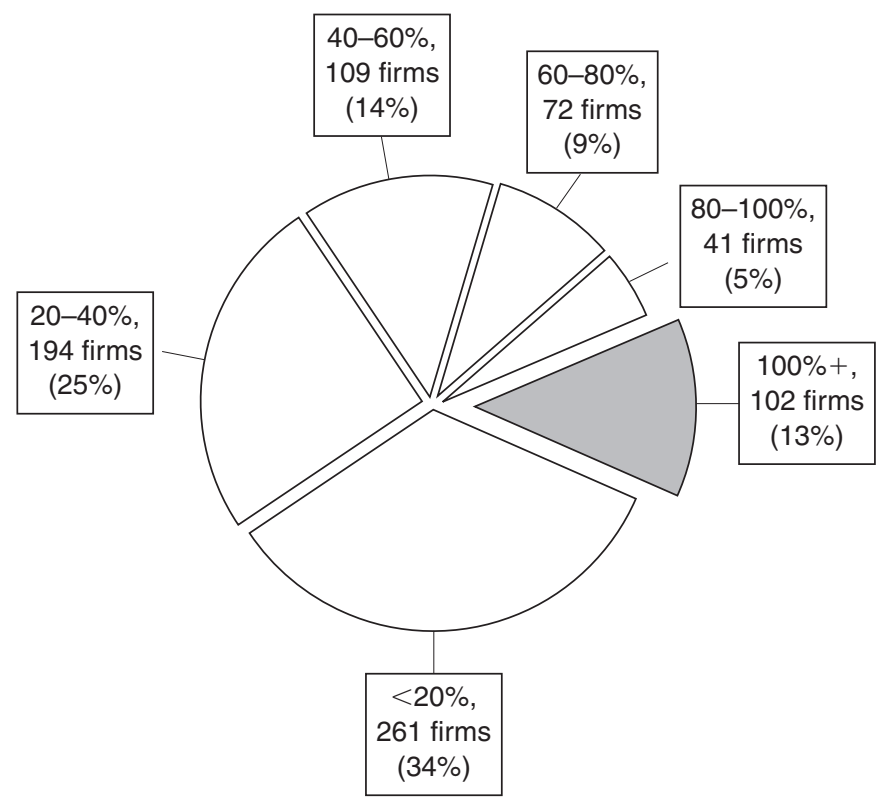

Figure 4.2 Ratio of bust-up value to market capitalization, 2000. 
al. 1999). A comprehensive study of survey results and qualitative data finds little support for the rhetorical claim that lifetime employment practices are coming to an end (Kato 2001). As one recent study concluded, "[t]hus far, there has been no evidence that firms have changed their longterm employment system in the manufacturing sector except for a few firms that have faced financial distress" (Miyajima and Aoki 2002).

In sum, with some important variations at the margins, Japanese management appears to be operating within the same basic set of incentives as ten years ago.

\section{Explaining the pattern of change and non-change}

Our survey of the past decade of corporate law and governance in Japan raises two major questions. Why has there been so much corporate law reform? And why have actual changes in corporate governance practices to date been far less sweeping than the changes in formal institutions?

\section{Why so much legal reform?}

The accelerated pace and expanded scope of corporate legal reform over the past decade reflect changes both in the macro economy and the political economy of Japan (see Kanda 2000). First, the Commercial Code has traditionally contained "surprisingly paternalistic, archaic and impractical concepts" (Osugi and Zaloom 2002, 2), particularly in relation to corporate finance and organizational structures. To cite just a few examples, until recently repurchase of a company's own stock was prohibited except in narrowly defined circumstances, severe limitations were placed on the kind of equity stock that a company could issue, and holding companies were banned. While these rules were designed to protect creditors and shareholders, some scholars have termed the restrictions "senseless" (see Ramseyer and Nakazato 1999; Osugi and Zaloom 2002). Senseless or not, these restrictions had little impact on Japanese economic activity in the high growth period. Because bank lending was the dominant mode of corporate finance for much of the postwar high growth period, the Code's strict restrictions on equity finance techniques and emphasis on technical creditor and shareholder protection posed little obstacle to firms. Indeed, a relatively mechanical, rule-oriented approach to corporate law may have complemented Japan's small judiciary and accounting profession (Kanda and Fujita 1998; Osugi and Zaloom 2002) ${ }^{20}$ However, as the economy stalled and many corporate sectors were in need of massive restructuring, these serious constraints on organizational form and corporate finance began to block needed reforms.

Second, as corporate managers became increasingly conscious of the organizational straightjacket imposed by the Commercial Code, particularly in comparison to U.S. firms, the political economy of Commercial 
Code reform changed significantly. Put differently, the market for the production of corporate law became much more competitive. Through the mid-1990s, Commercial Code amendments were the province of a small group of legal scholars and Ministry of Justice officials, who convened a Legislative Reform Council to study - often for years - the propriety of potential amendments. Under this process, the law changed, but relatively slowly and seldom in response to the exigencies of the market (although quite often in response to scandals [West 2001b]). In the words of one scholar, much corporate law reform over the past century was "policy pushed," rather than "demand pulled" (Shishido 1999). But the law reform process changed dramatically in the latter half the 1990s. Stock options are the first illustration of the change. The success of Silicon Valley's venture capital industry drew envious glances from the Japanese, whose own VC market was inhibited by a variety of legal rigidities (Milhaupt 1997). For example, various Commercial Code restrictions made the issuance of stock options virtually impossible. This prompted an unprecedented reform of the Commercial Code in 1997, which liberalized the stock option regime. For the first time in postwar history, an amendment was initiated by politicians rather than bureaucrats working through the Legislative Reform Council, as the business community prevailed upon Diet members to bypass the traditional, ponderous amendment process (Kanda 2000). Since 1997, the business community, working through their political allies in the Liberal Democratic Party, has had a much larger voice in the corporate law reform process. ${ }^{21}$ Other recent examples of direct business and political input in the production of corporate law include the 2001 amendment permitting firms to limit the personal liability of directors for breach of duty, and withdrawal of a Ministry of Justice draft amendment requiring the appointment of at least one outside director to the board of large corporations.

In addition to politicians and business groups, the Ministry of Economy, Trade and Industry (METI, the successor to Ministry of International Trade and Industry or MITI) has also become actively involved in corporate governance reform. Over the past several years, it has promoted a number of special statutes on corporate issues (Kanda 2000). These special statutes, which will likely be incorporated into the Commercial Code in the future, seek to create a more favorable environment for business startups and large-scale corporate restructurings. More broadly, METI now actively monitors and publicly intervenes in corporate governance issues, supporting the creation of a market-oriented, flexible institutional framework for business activity. This is a remarkable role reversal for a ministry that, in the high growth era, often served to enforce - informally, through administrative guidance - anti-competitive agreements worked out in consultation with industry. There may be many reasons why the ministry changed stripes. Discussions with officials suggest concern about the international competitiveness of Japanese firms and frustration over the failure 
of monetary and fiscal policy to restore the country's economic health. In this environment, the creation of a sound institutional framework for corporate restructuring and good governance practices is seen by METI officials as a logical focus of the ministry's efforts.

Thus, in effect, the Legislative Reform Council now has active competitors in the corporate law reform process: politicians working closely with business interests, and METI. The result of this competitive pressure is more "demand driven" corporate law amendments, made at an accelerated pace. "Demand driven" law can reflect the parochial interests of organized groups, or it can be responsive to broader public interests. As we will see in the next section, the decade's corporate law amendments reflect both characteristics.

\section{Why not more behavioral change?}

Despite a sea change in Japanese corporate law and the process by which it is produced, to date there has been no sea change in Japanese corporate governance. Why? Two fairly prosaic reasons can be mentioned: legal change often outpaces behavioral change, and some important Japanese actors remain unconvinced of the need for corporate governance reform despite a decade of economic turmoil. The latter point might be termed the "Toyota Effect," because that firm, simultaneously one of Japan's most successful and traditional, is the example universally proffered by those who defend the status quo in Japanese corporate governance. Without discounting the importance of those factors, I wish to concentrate here on three deeper explanations for the lack of change, one based on institutional com-

plementarities, the second drawn from learning on political economy, and the third related to the limits of corporate law as a vehicle for reform.

It is now commonplace to understand corporate governance systems as a series of complementary institutions. As Gilson (2001a, 335) puts it, a "corporate governance system's development is driven, domino-like, by the linking of complementary institutions." Milgrom and Roberts (1994) were among the first to view the major components of Japanese corporate governance in its heyday - the main bank system, lifetime employment, stable shareholding patterns, and relatively weak capital markets, as institutional complementarities. When complementarities are at work, the separate pieces that make up the entire system display increasing returns characteristics; their inclusion enhances the effectiveness of the other parts of the system, so that the whole is greater than the sum of the parts. But complementarities have a dark side in times of institutional change: piecemeal reform of complementary systems is problematic, because the same dynamic that increases returns when the system is functioning as a whole works to exaggerate the downside when one element of the system breaks down or is replaced. The result may be a whole that is less than the sum of its parts.

It is useful to view the developments in Japanese corporate governance 


\section{Curtis J. Milhaupt}

over the past decade in light of these insights. Although many formal rules and structures have changed, important complementary institutions necessary to complete the new system are still missing. Many examples could be offered to illustrate this point, but I will focus on three. First, while shareholders' legal rights have been strengthened by lowering filing fees and reducing minimum shareholding thresholds for their exercise, complementary facets of the legal and financial disclosure systems that would complement these rights are still not fully in place. The population of Japanese lawyers and judges remains extremely small by international standards. Access to evidence as a plaintiff can be problematic, as Japan lacks a formal discovery system for the production of evidence. The courts are still relatively disinclined to apply broad standards and create flexible remedies to resolve cases (although their response to recent hostile takeover cases suggests this may be changing [see Milhaupt]). And while Japanese accounting standards are now consistent with international standards, accounting practices lag behind.

A second example can be found in the new Civil Rehabilitation Statute. This new regime appears to be quite efficient (in terms of the length of time from filing to resolution) both in relation to the predecessor statute and in comparison to U.S. corporate reorganization procedures (see Xu 2002). A more efficient bankruptcy regime in Japan is an important component of an institutional structure that promotes the efficient allocation of resources. Yet the impact of this new bankruptcy regime on resource allocation will be muted if many functionally insolvent firms continue to operate under soft budget constraints because their lenders continue to exercise forbearance (see e.g. Regional Banks Should be Spared from Bad Loan Target 2003). Thus, political and social will to end bank support to insolvent firms is a necessary complement to good bankruptcy laws.

A third example is board reform. The trend toward smaller boards having some representation by outside directors, and a separation of functions between directors and executive officers, is intuitively more conducive to strategic decision-making and effective monitoring. ${ }^{22}$ Yet, as shown in the data on takeovers in the previous section, there is still little threat that value destroying decisions by Japanese management will lead to their replacement by a hostile acquirer or at the behest of a large, disgruntled shareholder. The missing market for corporate control would complement the trend toward smaller, more strategically focused boards.

A second explanation for the muted nature of corporate governance change to date is provided by theory on the operation of political markets and the legislative process. Mancur Olson (1982) predicts a rent-seeking political response to economic distress by threatened interest groups. Consistent with this model, Japanese business groups (representing the interests of corporate managers) have significantly increased their voice in the corporate law production process. The impact of this input is readily apparent from a review of the decade's amendments. As noted above, the 
amendments of the past ten years can be viewed as either flexibility enhancing or monitoring enhancing. We can assume that management would favor the former type of amendment, since greater flexibility enhances managerial discretion and at least potentially increases agency slack between managers and shareholders. Several flexibility-enhancing amendments are indisputably management favoring - for example, the 2001 amendment authorizing limitation of personal liability of managers, and authorizing share acquisition rights, which will be useful in constructing defenses to hostile takeovers. ${ }^{23}$ While some amendments have enhanced the ability of shareholders to monitor management, they were enacted prior to heavy business involvement in the corporate law amendment process. More recent amendments that are ostensibly monitoring enhancing, namely reforms to the statutory auditor system, may have actually served as a means of staving off more drastic corporate governance reforms such as mandating the use of outside directors (Osugi and Zaloom 2002). At least under the existing equilibrium, with relatively weak pressure from the capital markets and institutional investors, many of the rule changes over the past decade have the effect of expanding the scope of managerial discretion without ensuring that such discretion is utilized to enhance shareholder value.

The upshot is that until the environment external to the formal corporate governance structure changes, shareholders may or may not benefit from the new legal regime, depending on whether management of a given firm utilizes the newfound flexibility provided by the corporate law to pursue enhanced shareholder value, or to further insulate itself from market discipline.

This point leads to a third explanation for the relative lack of change despite massive corporate law reform: corporate law bears only a limited relationship to corporate governance. The point is best made by turning to the experience of the United States in the 1980s. American corporate governance underwent enormous functional changes in the 1980s, but these changes were not driven by changes in the formal structure of the governance system. Indeed, the corporate statutes changed very little at this time - although critically, "the existing formal structure proved sufficiently mutable to accommodate the necessary changes" (Gilson 2001b, 9). Rather, the existing legal system became "supercharged" by changes in product markets, capital markets, and the distribution of shareholders (ibid). These changes to the corporate governance system created forces for change so powerful that those favoring existing institutions, particularly senior management, could not contain them. The result was a dramatic transformation in American corporate governance, from a system that served largely to protect value-destroying decisions by insular groups of senior executives to a model whose attributes "animated international reform proposals" (ibid., 8), at least until the Enron and other corporate debacles of 2001-02 exposed the U.S. system to intense criticism. 


\section{Curtis J. Milhaupt}

Now return to the Japanese experience of the 1990s and early 2000s. As a result of the past decade's amendments, Japan now has a corporate code that permits mutability and is consistent with active shareholder monitoring. But as the experience of the United States in the 1980s demonstrates, the corporate law can facilitate, but not initiate, change in corporate governance. Substantive change is brought about by dynamics external to formal corporate governance institutions. The sea change in Japanese corporate governance practices will occur when Japan experiences transformations analogous to those occurring in the United States in the 1980s - transformations that force management to abandon their attachment to existing institutions. A partial catalogue of heretofore incomplete changes in underlying institutions, practices and mindsets includes the following: a new distribution of shareholders, brought about through increased foreign direct investment and further reductions in cross shareholding; a new approach to the capital markets by both firms and regulators, such as (on the private side) increased investment of retirement funds in equities and greater use of hostile acquisitions as a device of managerial replacement, and (on the public side) abandonment of governmental attempts to manage stock prices for the "benefit" of banks, which still hold large portfolios of under-performing shares; new incentive structures for senior management, who, short of financial crisis, currently have little incentive to do anything but await comfortable retirements; and further erosion of existing corporate norms that stigmatize redeployment of corporate assets to higher value uses as signaling "failure" or involving "the sale of people."

It is often said that Japan should retain beneficial aspects of its corporate governance system rather than rushing to emulate U.S. practices. Fair enough, but no commentators dare to be specific about which practices should be retained and which should be changed. Japanese managers will discover the answer only when they are forced to adapt. The corporate law now permits, but does not require, them to do so. Only the surrounding institutions, which contribute importantly to the incentive structures of corporate managers, have that power.

\section{Conclusion}

It has not been a lost decade for corporate governance reform in Japan. As a result of massive legal change, a formal institutional framework conducive to good corporate governance is now in place. Early signs suggest that academic and other observers are wrong to harbor grave doubts about the effectiveness of legal reforms in altering Japanese corporate behavior (Columbia Conference 2001; Root 2001). The experience of the past decade indicates that Japanese corporate actors do respond to legal reform, particularly reforms that lower the transaction costs of exercising shareholders' rights and doing deals. 
But legal change alone is insufficient to transform corporate governance practices. That transformation will require an even more complex set of changes in incentive structures and attitudes prevailing throughout the economic system. This larger set of changes is under way, but far from complete.

To return to the metaphor from the new institutional economics, although the game has new rules, play will truly change only when new players enter in large numbers, or existing players are encouraged (or forced) to abandon the rules to which they have become accustomed, and under which they continue to prosper personally. Or perhaps as other complementary institutions change outside the corporate environment, the players will find incentives to adjust to the new rule structure. ${ }^{24}$ Corporate law and governance is, for this reason, a highly salient subject for a study of institutional change and non-change in Japan.

\section{Acknowledgments}

I received helpful comments from Bruce Aronson, Mark West, Anthony Zaloom, volume editors Magnus Blomström and Sumner La Croix, and participants at the Institutional Change conference in Honololu, particularly David Johnson. Conversations with Hideki Kanda at an early stage of the project were also extremely helpful.

\section{Notes}

1 My view is that shareholder wealth maximization should be the principal goal of corporate law and governance, not because it is the only valid goal, but because pursuit of this objective helps ensure that management adds value to the enterprise, and provides a fairly transparent baseline against which to measure managerial performance. I acknowledge that the point is debatable. See Allen and Gale (2002) for a theoretical model showing that under some circumstances, Japan-style "stakeholder" capitalism can do better than AngloSaxon shareholder capitalism.

2 Only "pretty good" because the Commercial Code retains some arcane requirements like stated capital, and paternalistic features, such as supermajority voting to approve mergers, which are protective of shareholders in a rather mechanical and inflexible way.

3 A derivative suit is brought by a shareholder to enforce a corporate cause of action. The action seeks recovery, on behalf of the corporation, for damages caused by a director's breach of duty.

4 Commcercial Code, Art. 280-19.

5 Law No. 71, June 6, 1997.

6 Commercial Code, Art. 352 et seq.

7 Commercial Code Art. 373 et seq.

8 Commercial Code, Art. 210 et seq. (acquisition of company's shares); Art. 222 (classes of shares).

9 In a prepackaged bankruptcy, the creditors agree upon the essential terms of the restructuring plan before the bankruptcy filing. This is designed to reduce the length and complexity of the proceedings, and to minimize judicial intervention. Prepackaged bankruptcies were pioneered in the United States. 


\section{Curtis J. Milhaupt}

10 Compare, for example, Delaware corporate law, under which any shareholder may inspect corporate books and records for any proper purpose. Del. General Corporation Law, Section 220.

11 Law for Special Exceptions to Commercial Code Concerning Audit, Etc. (Special Exception Law), Arts. 18, 18-2.

12 E.g. Special Exception Law, Art. 18 (at least half of auditors must be independent); Commercial Code Art. 260-3(1) (requiring auditors to attend meetings of the board); Art. 273 (four year term).

13 Special Exception Law, Arts. 21-5 et seq.

14 Special Exception Law, Arts. 21-5, 21-15. Previously, there was no legal distinction between directors and officers, although beginning in the late 1990s companies had begun to informally make the distinction by creating an executive officer (shikko yakuin) position for executives who did not simultaneously serve on the board.

15 Nishimura v. Abekawa (The Daiwa Bank Case), 199 Shiryoban shoji homu 248, 255 (D. Ct. Sept. 20, 2000).

16 For more detail, see Milhaupt and West (2003).

17 Sources: Thomson Financial, Merger Yearbook (various years); Recof (2001, 2002).

18 A survey conducted in mid-2002, about ten months prior to the availability of the "committee option," indicated that just 13 (0.5 percent) of the 2,513 responding firms would switch to the committee-based structure (JCAA 2002). As of this writing, the major exception to the general lack of interest in the committee option is the electronics industry. Major firms in that industry such as Sony and Hitachi have adopted the committee structure. The precise reasons are unclear, but appear to include a desire to signal that the firm has "modern" and internationally accepted corporate governance mechanisms, and a "followthe-leader" effect, as Sony was the first to adopt this structure.

19 Source: Nomura Research Institute (2001). Bust-up value is defined as cash and cash equivalents + investment securities - short- and long-term debt. Calculated for 779 non-financial Tokyo Stock Exchange Firms as of November 2000.

20 By contrast, flexible and permissive corporate laws empowering boards to engage in any lawful activity, subject only to the constraints of fiduciary standards applied ex post by courts to police selfish or grossly inattentive managerial behavior - characteristics of U.S. corporate law (see e.g. Chandler and Strine 2003) - complement a fairly robust financial disclosure regime and an expansive legal system, featuring a large legal profession, a judiciary comfortable with the application of broad standards as opposed to narrow rules, and a procedural environment replete with procedural mechanisms to promote private litigation as a tool of enforcement.

21 For example, Seiichi Ota, the chairman of the Liberal Democratic Party's Subcommittee on Commercial Law, leaves no doubt that his subcommittee placed priority on ensuring that the business community's views were reflected in recent Commercial Code amendments (see Ota 2002).

22 Most empirical studies to date have not established that independent directors contribute to firm performance (see e.g. Bhagat and Black 2002).

23 Commercial Code, Arts. 266(7) through 266(19) (limitation of directors' liability); Arts. 280-19 through 280-39 (stock acquisition rights). Under the amendment, stock acquisition rights can be issued to anyone without shareholder approval, at an exercise price to be determined by the board. This makes technically feasible a defensive tactic widely used in the United States known at the poison pill. The poison pill is a plan whereby existing shareholders obtain the right to purchase additional shares of the company (typically for a nominal sum) upon the occurrence of a triggering event, such as a takeover attempt. 
24 To take just one example, institutional investors may become more aggressive in seeking financial returns from portfolio firms as Japan's aging population places increasing demands on the pension system.

\section{References}

Akaishi, Koichi. 2002. "Kikan toshika no coporeto gabanansu katsudo no igi waga kuni no kikan toshika wa kokateki na gabanansu katsudo ga dekiru ka" [The Signficance of Corporate Governance Activities by Institutional Investors: Can Institutional Investors in Our Country Play an Effective Role?]. Unpublished report. Research Institute of Economy, Trade and Industry.

Allen, Franklin and Douglas Gale. 2002. "A Comparative Theory of Corporate Governance." Unpublished working paper.

Aoki, Masahiko. 2000. Information, Corporate Governance, and Institutional Diversity: Competitiveness in Japan, the USA, and the Transitional Economies. Oxford: Oxford University Press. Translated by Stacey Jehlik.

Bhagat, Sanjai and Bernard Black. 2002. "The Non-Correlation Between Board Independence and Long-Term Firm Performance." Journal of Corporation Law 27: 231-73.

Chandler, William and Leo Strine. 2003. "The New Federalism of the American Corporate Governance System: Preliminary Reflections of Two Residents of One Small State." University of Pennsylvania Law Review (forthcoming).

Columbia Conference. 2001. "The New Rhetoric and Realities of Corporate Governance." Panel discussion at Corporate Japan: The Beginning of a New Era? held March 23, 2001.

"Diversity Distinguishes IY Bank." 2001. Nikkei Weekly, June 11, p. 13.

Gilson, Ronald. 2001a. "Globalizing Corporate Governance: Convergence of Form or Function?" American Journal of Comparative Law 49: 329-57.

Gilson, Ronald. 2001b. "Catalyzing Corporate Governance: The Evolution of the U.S. System in the 1980s." Unpublished manuscript.

Hansmann, Henry and Reinier Kraakman. 2001. "The End of History for Corporate Law." Georgetown Law Journal 88: 439-68.

Hisada, Kishiko et al. 1999. "Japan Sticks to Lifetime Job System.” Asahi Shimbun, December 2, 1999.

"Institutions Threaten Corporate Governance." 2002. Nikkei Weekly, July 22. Available on Westlaw (WLNR 1647285).

JCAA (Japan Corporate Auditors Association). 2002. Cited in letter from Group of Japanese Companies to the U.S. Securities and Exchange Commission, November 14.

"Jisha kabu kai baizo, 2 cho encho" ["Share Repurchases Double to Exceed 2 Trillion"]. 2002. Nihon keizai shimbun, April 28, p. 1.

"Kaisha bunkatsu: 1 nen de 200 ken" ["200 Spin-offs in One Year"]. 2001. Nihon keizai shimbun, March 31, p. 1.

"Kaisha ha koshite henshin saseru" ["This is How Corporattions Change"]. 2002. Shukan toyo keizai, April 6, pp. 42, 43-5.

Kanda, Hideki. 2000. "Reforms in Corporate Law and Financial Regulation in Japan." Unpublished manuscript.

Kanda, Hideki and Tomotaka Fujita. 1998. "Kabushiki kaisha ho no tokushitsu, tayosei, henka" ["Features, Variety and Evolution of Stock Corporation 


\section{Curtis J. Milhaupt}

Statutes"]. In Yoshiro Miwa et al. (eds) Kaisha ho no keizaigaku. Tokyo: Tokyo University Press, pp. 453-77.

Kato, Takao. 2001. "The End of 'Lifetime Employment' in Japan? Evidence from National Surveys and Field Research." Unpublished manuscript.

Kikuchi, Masatoshi. 2000. TOB, Kaisha bunkatsu ni yoru $M \& A$ senryaku $[M \& A$ Strategy: Takeovers and Spin-offs]. Tokyo: Toyo keizai shimbunsha.

"Mergers Snapshot." 2003. Wall Street Journal, April 2, C5.

Milgrom, Paul and John Roberts. 1994. "Complementarities and Systems: Understanding Japanese Economic Organization.” Estudios Economicos 9: 3-42.

Milhaupt, Curtis. 1997. "The Market for Innovation in the United States and Japan: Venture Capital and the Comparative Corporate Governance Debate." Northwestern University Law Review 91: 865-98.

Milhaupt, Curtis. 2001. "Creative Norm Destruction: The Evolution of Nonlegal Rules in Japanese Corporate Governance." University of Pennsylvania Law Review 149: 2083-129.

Milhaupt, Curtis. 2004. "Nonprofit Organizations as Investor Protection: Economic Theory, and Evidence from East Asia." Yale International Law Journal 29: 169-207.

Milhaupt, Curtis. 2005. "In the Shadow of Delaware? The Rise of Hostile Takeovers in Japan." Columbia Law Review 105: 2171-2216.

Milhaupt, Curtis and Mark West. 2003. "Institutional Change and M\&A in Japan: Diversity through Deals." In Curtis J. Milhaupt (ed.) Global Markets, Domestic Institutions: Corporate Law and Governance in a New Era of Cross-Border Deals. New York: Columbia University Press, 295-338.

Miwa, Yoshiro and Mark Ramseyer. 2003. "Financial Malaise and the Myth of the Misgoverned Bank. In Curtis J. Milhaupt (ed.) Global Markets, Domestic Institutions: Corporate Law and Governance in a New Era of Cross-Border Deals. New York: Columbia University Press, pp. 339-72.

Miyajima, Hideaki and Hidetaka Aoki. 2002. "Changes in the J-Type Firm: From Bank-Centred Governance to Internal Governance." In Javed Maswood, Jeffrey Graham and Hideaki Miyajima (eds) Japan: Change and Continuity. London: RoutledgeCurzon, pp. 72-105.

Nomura Research Institute. 2001. Unpublished data on ratio of bust-up value to market capitalization.

Olson, Mancur. 1982. The Rise and Decline of Nations: Economic Growth, Stagflation, and Social Rigidities. New Haven: Yale University Press.

Osugi, Kenichi and Anthony Zaloom. 2002. "Recent Amendments to Japan's Company Law: Drastic Overhaul or Just Tinkering?" Unpublished manuscript.

Ota, Seiichi. 2002. "Sentakusei' saiyo ga kansayaku seido wo tsuyoku suru." ["Adoption of the 'Elective System' will Strenghten the Statutory Auditor System"]. Torishimariyaku no homu 95: 4-7.

Posner, Richard. 1997. "Social Norms and the Law: An Economic Approach." American Economic Review 87: 365-9.

Ramseyer, Mark and Minoru Nakazato. 1999. Japanese Law: An Economic Approach. Chicago: University of Chicago Press.

Recof LLC. 2001. Mergers and Acquisitions Report.

Recof LLC. 2002. Online. Available at: www.recof.co.jp/01_market/index.htm. Accessed October 1, 2002.

"Regional Banks Should be Spared from Bad Loan Target." 2003. Nikkei Net Interactive, March 19. 
Roe, Mark. 2003. "What Corporate Law Cannot Do.” In Curtis J. Milhaupt (ed.) Global Markets, Domestic Institutions: Corporate Law and Governance in a New Era of Cross Border Deals. New York: Columbia University Press, pp. 107-51.

Root, Hilton. 2001. “Asia's Bad Old Ways.” Foreign Affairs 80(2): 9-14.

"Shagai torishimariyaku 38\% ga sennin" ["38\% Choose Outside Directors"]. 2001. Nihon keizai shinbun, June 16, p. 1.

Shishido, Zenichi. 1999. "Reform in Japanese Corporate Law and Corporate Governance: Current Changes in Historical Perspective." American Journal of Comparative Law 49: 653-77.

Shoji homu kenkyukai. 1999. "Kabunushi sokai hakusho" ["White Paper on Shareholders' Meetings"]. Shoji homu 1234: 3-118.

Thompson Financial. Merger Yearbook, various years.

Thomson Financial. 2002. “Japanese M\&A: Stayin' Alive”, April 4. Online. Available at: www.tfibcm.com/league/pdfs/MA/4Q2001/Docs/4Q01JapanesePR.PDF. Accessed October 1, 2002.

Tokyo shoken torihikijo [Tokyo Stock Exchange]. 2000. "Kooporeto gabanansu ni kansuru ankeeto no chosa kekka ni tsuite" ["Results of Corporate Governance Survey"]. November 30.

Towers Perrin. 2003. Worldwide Total Compensation Report 2003-2004.

West, Mark. 2001a. "Why Shareholders Sue: The Evidence from Japan." Journal of Legal Studies 30: 351-82.

West, Mark. 2001b. "The Puzzling Divergence of Corporate Law: Evidence and Explanations from Japan and the United States." University of Pennsylvania Law Review 150: 527-601.

Xu, Peng. 2002. "Bankruptcy Resolution in Japan: Corporate Reorganization vs. Civil Rehabilitation." Unpublished paper.

Yasui, Takahiro. 1999. "Corporate Governance in Japan.” OECD paper, March.

Zhang, Hua. 2000. "Share Repurchases in Japan: Market Reaction and Actual Implementation." Unpublished manuscript. Online. Available at: www.efmaefm.org/hzang.pdf. Accessed October 1, 2002. 


\title{
5 Japan's economic and financial stagnation in the 1990s and reluctance to change
}

\author{
Thomas F. Cargill
}

\section{Introduction}

Japan's postwar economic performance is remarkable. ${ }^{1}$ In fact, with the exception of World War II and its immediate aftermath, the overall economic development of Japan starting with the Meiji Restoration in 1868 to the late 1980s is impressive by any standard. Rising from the ashes of defeat in World War II Japan achieved "Asian Miracle" status by the late 1980s. At this point, however, Japan fell into an economic, financial, and political malaise that continued through 2002. Starting in 2003 Japan began a tentative recovery. Real GDP increased in 2003 (Figure 5.1), but slowed in the first three quarters of 2004 with a quarter-to-quarter change of -0.1 in the second quarter (Bank of Japan, January 2005). Price deflation has decelerated since 2002 (Figures 5.2 and 5.3), with predictions that it will end in 2006. There has been progress in reducing financial distress. Nonperforming loans remain large in the banking system, but have declined in the past few years as the Financial Services Agency increased pressure to reduce nonperforming loans and has indicated that nonperforming loans should by March 31, 2005 be half of their level in March 2002. Japan is well past the risk of large bank failures that concerned many in the late 1990s.

The economic and financial distress since 1990 stands in sharp contrast to the overall economic and financial stability of Japan in the previous four decades. Likewise, the political instability since 1990 stands in sharp contrast to the political stability provided by the dominance of the Liberal Democratic Party (LDP) from 1955 to 1993. Japan experienced about one new prime minster each year since 1990 until Junichiro Koizumi assumed power in April 2001. Koizumi, even though a product of the LDP, proposed far more aggressive reforms than previously enacted, including privatization of the Postal Saving System (PSS). Public confidence in Koizumi has declined somewhat during his tenure as prime minister, but he will likely remain a strong political force during the remainder of his term that ends in late 2006. Despite his aggressive leadership, Koizumi has encountered considerable resistance to resolving the nonperforming loan 


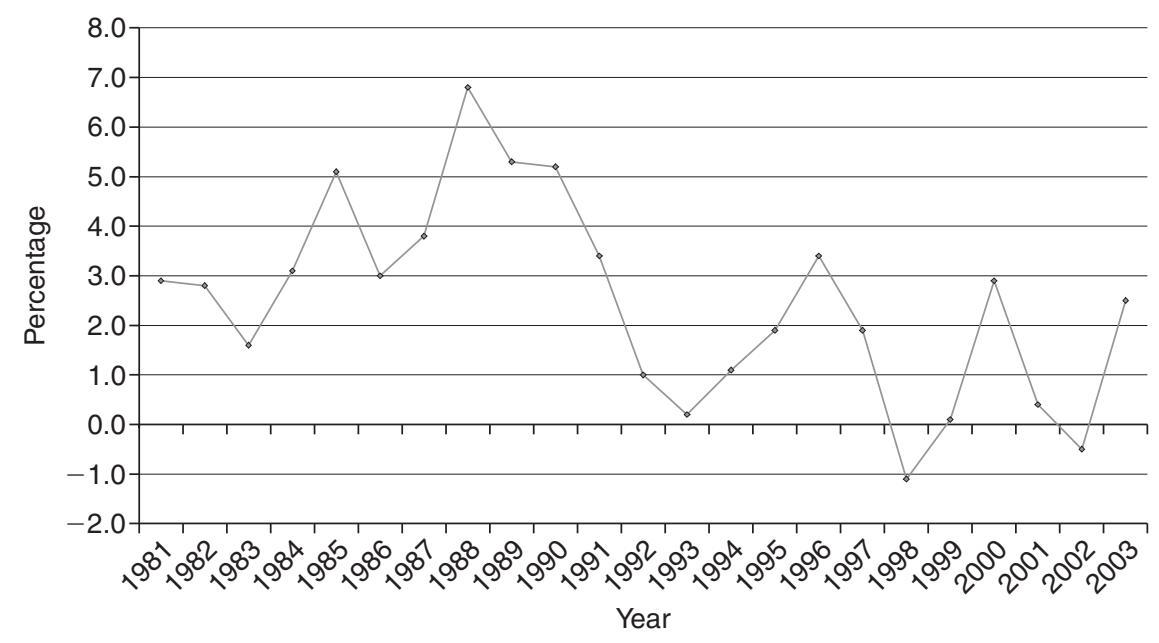

Figure 5.1 Percentage changes in real GDP.

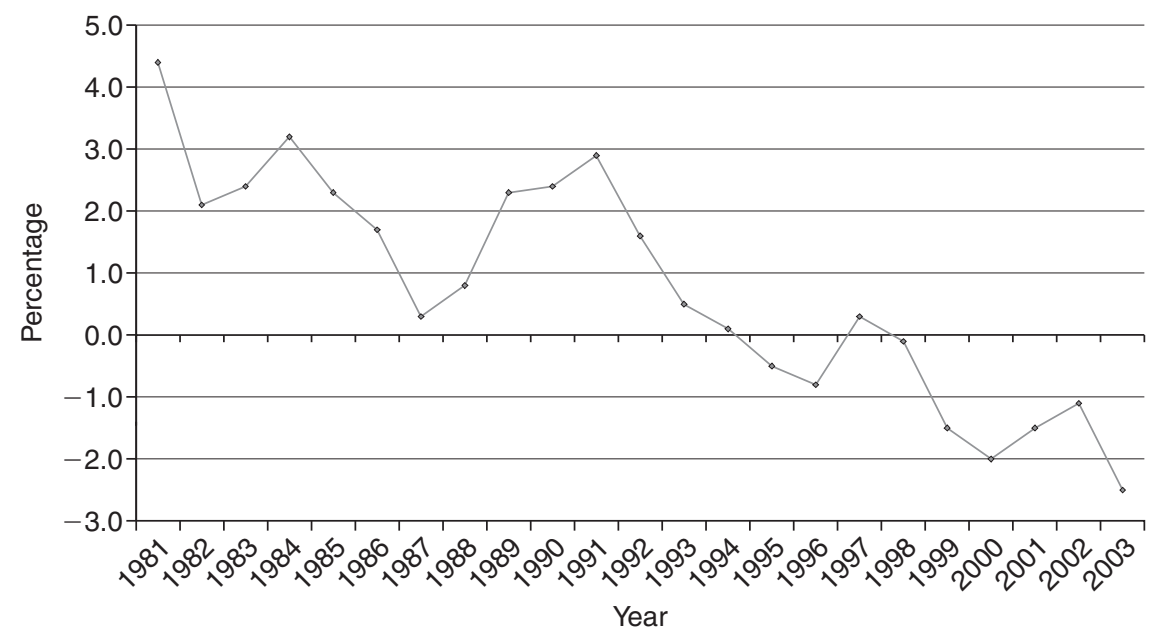

Figure 5.2 GDP deflator, percentage changes.

problem, closing troubled financial institutions, and especially privatization of postal savings. There continues to be an entrenched political establishment wedded to the old mutual support regime based on forgiveness and forbearance of troubled firms and industry as the preferred policy instead of making the type of major structural reforms needed in Japan. Many believe that new leadership in 2007 will be less reform minded, especially if the economic recovery continues. 


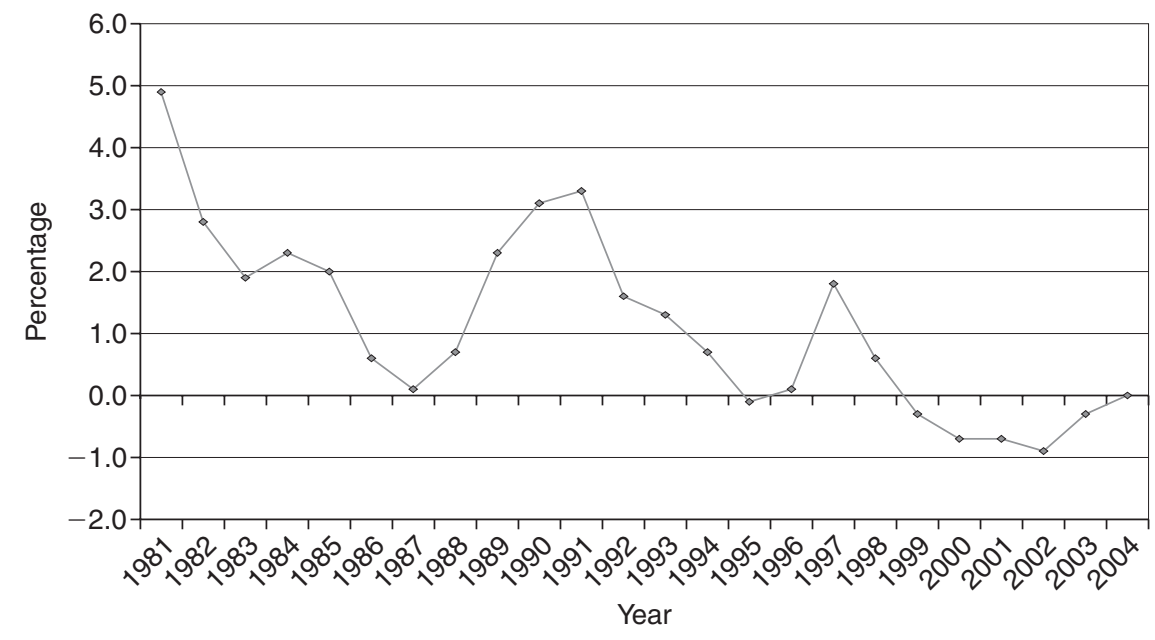

Figure 5.3 Percentage changes in the CPI.

The level of economic and financial distress and political instability in the 1990s is the more remarkable considering the extensive efforts made to deal with the problems, especially since 1995 . There have been a series of fiscal stimulus packages of increasing size and the Bank of Japan has implemented a zero interest rate policy since February 1999 except for a few months following August 2000 when the Bank of Japan raised the targeted interbank rate slightly. Major institutional redesign has taken place throughout the financial system. The Financial Services Agency (formally, the Financial Supervisory Agency) was established April 1, 1998 to assume the financial regulatory and supervisory responsibilities previously held by the Ministry of Finance. The Bank of Japan's independence was significantly enhanced as of April 1, 1998. Deposit insurance was reorganized in 1995 to provide the primary safety net for the financial system and Prompt Corrective Action was accepted as the proper approach in dealing with troubled institutions. The Fiscal Investment and Loan Program (FILP) system was reformed April 1, 2001 to make it more transparent and market sensitive. In December 2002 a new deposit insurance guarantee was established effective April 1, 2005. In addition to institutional redesign, major attitudinal changes have taken place.

Many policymakers now recognize that the economic and financial regime that served Japan so well during much of the postwar period is no longer compatible with the new economic, technological, and political environment facing Japan. Policymakers have also come to accept that moral hazard is not a problem unique to market-oriented financial regimes and that forgiveness and forbearance ultimately increase the economic 
and political costs of resolving the nonperforming loan and nonperforming borrower problems.

The juxtaposition of efforts to stimulate the economy and redesign the financial system and the economic and financial distress that lasted over a decade, followed by a recovery in 2003 whose sustainability is not assured (Patrick 2004), raises an important question. Why has recovery been so long in coming, and why is there still concern about the sustainability of the recent recovery? This chapter offers some perspectives on the resistance to change and the difficulty Japan has experienced in returning to sustained growth. The remainder of the chapter is composed of seven parts.

In part I a general framework or taxonomy of financial reform applicable to any reform process is outlined as a background for discussing the failures of financial redesign in Japan. The outline is based on a sequence of events that describe the financial reform process in terms of factors that initiate the shift from an "old" to a "new" financial regime, the internal resistance to the transition, and the feedback relationships between the public and private sectors that occur during the transition. In particular, the basic theme of the outline is that resistance to institutional redesign is normal and that one can reasonably identify those factors responsible for differing policy outcomes across countries.

Part II discusses a number of restraints embedded in the Japanese financial system that help us understand why reform has been so slow and incomplete. These restraint factors are referred to as country-specific restraint factors because they reflect the basic foundation of the old Japanese financial regime. In other words, these restraint factors are special to the Japanese financial regime as it developed over the postwar period. In contrast, part III discusses resistance factors not fundamental to the financial regime and, hence, are not country-specific; that is, these factors are potential problems for any country. These factors are referred to as general or global restraints. In the case of Japan, policy failures on the part of the Bank of Japan represent the major general restraint on recovery.

Part IV discusses the FILP and PSS as examples of the difficulty of change in Japan's financial system. The FILP and PSS have resisted meaningful reform until only recently, despite an official policy of liberalization, and more than any other financial institution they reflect key elements of the old regime. Reform has commenced, but it is too early to determine whether Japan can significantly reduce the role of government financial intermediation. The PSS, now know as the Japan Post, remains a government corporation and continues to be a large presence in the financial system. Despite the recent plans to privatize the Japan Post, many issues remain unresolved.

Part $\mathrm{V}$ raises the issue of whether the Japanese financial regime was sustainable even in the absence of the economic and financial distress of 


\section{Thomas F. Cargill}

the 1990s. That is, would other events have eventually generated economic and financial distress in Japan? Two factors are identified that suggest the regime was not sustainable.

Part VI focuses on demographic factors that are rapidly reducing Japan's window of opportunity to resolve the economic and financial distress. A short concluding section ends the chapter.

\section{Common sequence of financial reform but different policy outcomes}

Financial liberalization has been an ongoing process in a wide range of developed and developing countries since the 1970s. Despite different economic and political institutions, history, and culture, the financial reform process in virtually every country follows a common sequence that can be described by the following points:

There is a given pre-reform institutional design of the financial regime consisting of private financial institutions, markets, government regulatory authorities, and central banking institutions.

\section{$\downarrow$}

The given institutional design conflicts with a new economic, political, and/or technological environment.

The conflicts interfere with the ability of the given financial regime to meet basic responsibilities. The conflicts can be manifested in a variety of ways ranging from failures of financial institutions to sharp shifts in the allocation of funds among financial institutions.

$\downarrow$

The resulting financial disruptions and inefficiency stimulate market and regulatory innovations.

Market and regulatory innovations are resisted by various regulatory authorities unwilling to depart from the old regime because they view the transition as a potential loss of regulatory power.

Market and regulatory innovations are also resisted by various private sectors unwilling to depart from the old regime because they view the transition as a potential loss of property rights and rents enjoyed under the old regime.

The degree of the resistance from the public and private sector determines the timing, the completeness, and the stability of the transition from the old to the new regime. 
Financial reform becomes a two-way feedback process between the public and private sectors in that reform requires institutional redesign of both private and public institutions.

$\downarrow$

The financial reform process is stable or unstable depending not only on the degree of resistance to redesign from the private and public sector, but also on central bank policy, existence and extent of money and capital markets, degree of interface between domestic and international finance, etc.

The specific characteristics of a country's financial design reflect the country's culture, history, and national economic policy goals. However, the basic function of providing an orderly and stable flow of funds and platform for monetary policy remains country invariant. Institutional redesign occurs when the financial regime's basic responsibilities are not achieved. This frequently occurs when the existing regime encounters a new environment that conflicts with one or more key elements of the existing financial structure. The new environment may consist of economic, political and/or technological forces. The reform process itself is a complex interplay between market innovations and government or regulatory innovations. This process is seldom smooth, however.

There is considerable resistance to financial reform and conflict between the various participants in the reform process. ${ }^{2}$ There is resistance from established groups possessing long-held property rights to regulatory rents embedded in the pre-reform financial regime. Private banks and depositors regard deposit guarantees as entitlements and hence resist any effort to reduce them and/or make them more market sensitive. Regulatory authorities resist reform if they perceive reform as a rejection of past regulatory policies and, more importantly, if they perceive reform as reducing their role or prestige in the new regulatory framework. No country is immune.

Once financial reform becomes an ongoing process, it frequently requires redesign of all of the major components of the financial structure including government regulatory institutions as well as nonfinancial components such as corporate governance and industrial organization.

Financial liberalization in the 1970s and 1980s commenced as a worldwide process when a new set of economic, political, and technological forces emerged. The process has not, however, been smooth in any country. Explanations for the lack of a smooth transition fall into one of three explanations.

The first view emphasizes the inherent instability in markets caused by rent-seeking activity in a less regulated environment and, hence, places the blame on liberalization. That is, providing markets with enhanced portfolio diversification powers allows market participants to assume imprudent levels of risk and increase the market's systemic risk as market participants seek to maximize their own profit. This view emphasizes 
market failure as the explanation for the lack of a smooth financial transition. The policy implication of this view ranges from return to the oldstyle of controls to a much slower pace of liberalization.

The second view does not regard liberalization as the problem and regards it as inevitable, but rather finds fault with the process of liberalization as carried out by government. The process has been uneven and sometimes disruptive because of government resistance to reform and willingness to pursue unbalanced reform in the context of government's unwillingness to impose bankruptcy on insolvent financial institutions and reduce government deposit guarantees. Regulatory authorities resist reform, because they perceive either a loss of regulatory influence or adverse effects on the sector they regulate. As a result, reform tends to be unbalanced and incomplete. Regulatory authorities resist lowering deposit guarantees because they have come to be viewed as entitlements by the public. As a result, moral hazard induces imprudent portfolio behavior on the part of financial institutions. Regulatory authorities are reluctant to close insolvent financial institutions. Instead, they adopt forgiveness and forbearance in dealing with troubled institutions and, hence, further increase moral hazard and increase the economic and political cost of resolving nonperforming loan and borrower problems. The degree of resistance to the process largely determines the economic cost of the transition. This view thus emphasizes government failure, rather than market failure, as the major contributing factor to an unstable transition process.

The third view combines the market failure and government failure views. The uneven financial liberalization process reflects elements of both that reinforce each other. The problem with the third view, however, is that it is more useful for understanding the uneven process of liberalization once in place, but does not provide much insight into the takeoff conditions that determine whether liberalization will be a stable or unstable process. In this regard, the first two explanations are the most useful.

Korea, Japan, and the United States illustrate the differing policy outcomes and the effect of the differing degrees of resistance on the policy outcomes. A brief comparative consideration of financial liberalization since the 1970s in Korea, Japan, and the United States is instructive for three reasons. ${ }^{3}$ First, the pre-liberalization financial regimes represented by the three countries represent the two ends of the financial spectrum, with state-directed and market-directed financial regimes at the opposite ends of the spectrum. Second, despite differing approaches to the liberalization process in each country, the accomplishments to date have reduced the role of state-directed elements and enhanced the role of marketdirected elements in the allocation of credit and the conduct of monetary policy. Third, the policy outcomes of the liberalization process, however, have been dissimilar. The United States achieved a reasonable transition to a more open and competitive financial design by the early 1990s, though only after considerable instability and hesitation (Benston and Kaufman 
1997). Korea, whose financial institutions are more closely modeled on the Japanese system than any other Asian country (Cargill 1998), was able to rebound early from the sharp decline in macroeconomic activity in late 1997 and 1998 (Korea Economic Institute 2002). While more successful than Japan in resolving economic and financial stress, Korea's ultimate success remains uncertain (Cargill and Patrick 2005). Japan's performance has been the least successful, not only among the three countries, but by almost any comparison with other countries that have attempted financial liberalization.

The differing policy outcomes can be attributed to a combination of cultural, philosophical, attitudinal, structural, and macroeconomic factors, especially monetary policy. It is somewhat arbitrary to attempt a classification scheme for the resisting factors; however, two broad classifications seem appropriate. First, there are country-specific resistance factors that reflect different organization and objectives of a financial regime, different attitudes over the role of government in the economy, and different approaches to the organization of the nonfinancial sector. The reference frequently made to structural resistance to reform is what is meant by country-specific resistance factors. Second, there are general or global factors that can be potential problems for any country that resists reform. These are referred to as general or global because they are not directly tied to the fundamental elements of the financial regime. The reference frequently made to macroeconomic policy errors is an example of a general or global resistance factor.

The distinction between country-specific and global factors may appear arbitrary since macroeconomic factors such as monetary policy reflect the fundamental structure of the financial regime and the structure of the financial system is dependent on how monetary policy is conducted. Despite the ambiguity, the two-part classification may be a useful way to disentangle factors that are special to Japan and those that are independent of Japan.

\section{County-specific factors that resist reform in Japan}

Japan's financial institutions first evolved during the Meiji Restoration in 1868 , reached maturity in the early 1950s, and manifested the following core elements: (1) the financial system was an instrument of industrial policy to ensure that financial resources were directed to support domestic investment and export industries; (2) the financial system was based on a bank finance model with close bank-firm relationships designed to evaluate and monitor credit to the large business sector: to ensure that large corporations had first access to credit, and minimize bankruptcies; (3) the financial system was designed to encourage household saving while at the same time limit household access to consumer and mortgage credit; (4) government financial intermediation provided funds to those sectors with limited access to private bank credit; (5) a policy of "no failures of 


\section{Thomas F. Cargill}

financial institutions and markets" and pervasive deposit guarantees supported by government regulation, nontransparency, and central bank lender of last resort powers was designed to provide a low-risk and lowbankruptcy environment for investment; and (6) market forces played a minor role while, overall, the flow of funds was constrained by government regulation and international isolation.

World War II and the Allied occupation were only marginal influences on the evolution of the Japanese financial regime, as the postwar regime was a continuation of the prewar regime. The financial regime from the start of industrialization in 1868 to the 1980s was successful by any reasonable standard. The prewar growth record, the rapid reindustrialization after World War II, the high growth period from 1950 to 1973, and the emergence of Japan as the second largest and one of the most stable economies in the world from 1975 to the late 1980s were all importantly dependent on Japan's financial institutions. As a result, Japan served as a model for other Asian countries.

This regime came under pressure to change in the second half of the 1970s and, on the surface, appeared by the second half of the 1980s to have achieved the world's smoothest transition toward open and competitive markets. ${ }^{4}$ It was also making process toward internationalization of the domestic economy while at the same time adjusting to the second oil price shock in 1979/1980 without the inflation-disinflation cycle common to almost every other industrialized economy. In hindsight, however, Japan's accomplishments were not sustainable and the "burst of the bubble" economy in the early 1990s and the subsequent economic, financial, and political distress were natural outcomes of the flawed and incomplete liberalization process started in the 1970s. This has become a well-known story, documented elsewhere..$^{5}$ The objective here, however, is to identify those characteristics specific to the Japanese financial regime that have resisted reform and made recovery elusive to date. The following discussion brings together the most important country-specific problems facing Japan, while the next section focuses on problems facing Japan not dependent on the Japanese financial regime.

\section{Financial liberalization was more rhetoric than substance}

Financial liberalization in Japan did not emerge from a renewed faith in market principles and reevaluation of the role of government in the economy. While important for the liberalization process in the United States, they were relatively unimportant in Japan (Lee 1992 and 2003). Japan's liberalization process was a reaction to pressure from well-organized internal and external interest groups that demanded liberalization for reasons of self-interest.

Banks and securities companies demanded liberalization to restore lost market share in a slower-growth environment and to expand market 
share, respectively. Corporations became advocates of liberalization since increased portfolio flexibility would allow them to earn higher returns on liquidity freed up from reduced reliance on bank credit and the need to maintain compensating bank balances. The Ministry of Finance was willing to supply liberalization to finance the large central government deficits that emerged after 1973.

External pressure to liberalize came from the Reagan administration in the United States in the early 1980s. While the U.S. liberalization process was more firmly rooted in market principles than in Japan, the U.S. was not above using liberalization as a component of trade policy. The U.S. Treasury in 1984 argued that Japan's favorable current account balance was the result of an artificially undervalued yen. The yen was artificially undervalued because the financial system was rigidly regulated and controlled and, as a result, the yen had little international investment or reserve asset value. That is, given Japan's large current account surplus and status as the second largest economy in the world, the yen should have been a more widely used investment and reserve asset. The problem was Japan's financial regime; hence, financial liberalization was viewed by the United States as a solution to a trade-imbalance problem.

The Ministry of Finance responded to these various pressures by first officially recognizing the gensaki market ${ }^{6}$ in 1976; relaxing constraints on the inflow and outflow of capital; enhancing portfolio diversification powers for banks, securities companies, and nonfinancial firms; removing interest rate ceilings on loans and deposits; and establishing money and capital markets. These were significant structural changes; however, they paled in comparison to the elements of the old regime left in place. Nontransparency, pervasive deposit guarantees, government financial intermediation, mutual support, and a general unwillingness to permit bankruptcy to play a role in the allocation of credit continued to define the Japanese "liberalized" financial system. Thus, official liberalization was more rhetoric and a response to specific interest groups than a commitment to redesign the financial regime. One observer at the time (the early 1980s) referred to Japanese liberalization as "bonsai" liberalization, meaning that open and competitive markets were acceptable as long as they progressed in the way the Japanese government wished them to progress. ${ }^{7}$

The view that financial liberalization in Japan in the late 1970s and 1980s was more rhetoric than substance needs to be qualified. Japan saw little need to overhaul the entire financial system given its successful performance in terms of financial stability and supporting impressive economic growth. Hence, it is understandable that Japanese regulatory authorities were not willing to change the basic structure of the system, but instead only respond to those interest growths as long as the changes left intact the essential elements of the old regime. This explains why government financial intermediation (PSS and FILP), deposit guarantees, transparency, and the role of bankruptcy were not major concerns among 
regulatory authorities. While such a partial equilibrium approach was not sustainable in the long run, Japanese regulatory authorities believed they could achieve a successful bonsai liberalization process.

This partial approach in the context of remaining committed to the key elements of the old regime, however, generated three consequences that contributed to Japan's current economic and financial distress. First, Japan's unbalanced and incomplete liberalization process in the presence of pervasive deposit guarantees exposed the system to moral hazard. Permitting enhanced portfolio diversification in the absence of financial disclosure and a weak monitoring system encouraged imprudent risk taking and weakened the quality of bank and borrower balance sheets. This in turn rendered the economy more susceptible to any type of shock, such as fiscal/monetary policy errors or a collapse of asset prices. Second, the expectation that policymakers could manage the financial system through administrative guidance made them less concerned about potential shocks and/or problems with the liberalization process. This expectation supported an overoptimistic assessment of the stability and soundness of the financial system and the ability to manage financial distress. There was the expectation that any serious problem could be handled, like in the past, through nontransparency, administrative guidance, and Bank of Japan lender of last resort services. Third, the adherence to key elements of the old regime made it more likely that the policy response to any type of shock would first be denial, followed by understatement, and then followed by a policy of forgiveness and forbearance. Japanese regulatory authorities are not unique in this regard; for example, U.S. regulatory authorities responsible for the Savings and Loan (S\&L) industry exhibited the same response. However, adherence to the old regime made it more likely that denial, understatement, forgiveness and forbearance would be resorted to in the face of finance distress and was likely to be pursued for longer.

\section{Japan is special and not susceptible to moral hazard and the regulatory-market dialectic}

Japanese writers sometimes bristle when references are made to the special or unique characteristics of Japanese economic institutions. But at the same time, Japanese policymakers perceived their economic and financial institutions to be immune to the type of financial disruptions that characterized the United States in the 1970s and 1980s. This view was based on the historical performance of the Japanese financial system and the expectation that administrative guidance in the context of an extensive mutual support system between the government and the private sector would ensure that Japan would not experience the type of S\&L and banking problems experienced by the United States in the 1970s and 1980s or the type of banking problems experienced in the Scandinavian countries in the late 1980s. The view that Japan was special was manifested by the large 
number of articles and books published in Japan, the United States, and elsewhere during the 1980s praising "Japanese management," "Japanese industrial policy," and "Japanese financial and monetary policy." The rapid growth of other Asian economies in the 1980s and the attention devoted by the World Bank (1993) to the special features of Asian economic institutions further supported the view that Japan was special.

Differing macroeconomic policy outcomes accounted for much of the difference in the process of financial reform across countries, especially with regard to Japan and the United States. The Federal Reserve failed to achieve price stability during the 1970s and early 1980s, while the Bank of Japan achieved an impressive record of price stability for most of the period from the early 1950s. The Bank of Japan's policy outcomes, especially after 1973, attracted worldwide attention because it was ranked as one of the world's most dependent central banks. As a result, the transition of finance was smoother in Japan than in the United States because of better central bank policy outcomes that narrowed the gap between regulated and unregulated interest rates. This, in turn, reduced incentives to innovate and generate regulatory-market conflicts (Kane 1981) that led to the financial disruptions in the United States.

Japanese policymakers regarded moral hazard issues that played a major role in the U.S. as relevant for individual-based/Western-type economic systems. Moral hazard had little relevance for a financial system based on social relationships in which mutual support and limiting risk were primary objectives. Japanese policymakers regarded the type of regulatory-market dialectic common in the United States as appropriate only for a formal codified legal system which permitted "loop-hole mining." In a system dominated by administrative guidance and informality, market participants were more likely to refrain from actions that were not expressly permitted by the regulatory authorities, whereas in the United States market participants would only refrain from actions that were expressly prohibited.

In hindsight, Japanese policymakers understated the contribution that the Bank of Japan made to the reform process and overstated the special nature of Japanese economic institutions. Disintermediation and moral hazard that characterized the U.S. reform process were absent in Japan because of better central bank policy outcomes and fewer opportunities for disintermediation.

\section{Japanese financial institutions have been successful, so why should Japan change?}

Japan's financial institutions, commencing with the start of industrialization in the 1870 s, were strong contributors to Japan's rapid growth. In a country lacking a tradition of markets, risk-taking, and individual as opposed to authoritative decision-making, bank finance in the context of 


\section{Thomas F. Cargill}

nontransparency and mutual support was well suited for transferring household savings to the industrial sector. While government credit allocation was not nearly as extensive as sometimes claimed by those who viewed Japan as "Japan, Inc.", the government did play an important role in maintaining a "no failure policy of financial institutions" as well as providing credit through the PSS and FILP to those sectors denied access to private bank finance.

Private and public institutions evolved to support export-led economic growth, provide for a high level of household saving, ensure that financial resources were used to support industrialization as opposed to consumption, and ensure international isolation. Japan's comparative economic growth has been well documented (Ito 1992) and emulated throughout Asia to varying degrees (World Bank 1993). The attraction to Japanese financial institutions among many Asia countries, formerly under Japanese military control, in the postwar period attests to their acceptance as an important part of the most prominent examples of the "Asian Miracle" identified in the well-know World Bank (1993) report on Asia.

Thus, economic and financial distress in the 1990s, at least up to late 1997, appeared as an outlier to many Japanese policymakers and, hence, they found it difficult to depart from a set of institutions that had served Japan so well for so long. This view rejects the notion that Japanese and Asian economic growth in general resulted from a special set of circumstances that could not be sustained (Cargill and Parker 2002; and Krugman 1994).

\section{Liberalized financial markets and institutions are incompatible with Japanese culture and belief systems}

Lee (1992 and 2002) and Lincoln (2001) have argued that characteristics of Japanese culture and belief systems make it difficult to adopt market-oriented financial institutions. According to Lincoln, for example, the matrix of social relationships, cultural characteristics, and economic institutions in Japan - especially the financial system - create binding constraints on reform.

The essence of Lincoln's argument is as follows. Markets require formality, whereas informality is a chief characteristic of Japanese society. Markets require a focus on short run (profit maximization) and limited dimensional transactions (price and quantity), whereas Japanese financial institutions focus more on long run (maintaining market share) and multidimensional transactions (complex customer relationships that go far beyond price and quantity to include management services, arranging connections with other firms, etc.). Markets require specialization and division of labor independent of social relationships, whereas Japanese economic and financial institutions directly incorporate social relationship characteristics such as long-term relationships, mutual support, and limiting risk. 
Markets require bankruptcy as a penalty function, whereas Japanese economic institutions are designed to limit market risk and, consequently, bankruptcy. Markets require transparency, whereas Japanese institutions emphasize nontransparency and facades.

Relying on cultural characteristics to explain economic institutions is generally played down among economists. However, the dichotomy between Japanese culture and markets is large and, hence, financial liberalization is at best a difficult process. Financial liberalization was a much easier process in the United States and other Western-oriented economies because their historical and cultural backgrounds were compatible with relaxing constraints on the flow of funds.

\section{Bank capital and BIS capital-asset requirements}

Japanese banks hold equity in nonfinancial firms - up to 5 percent of outstanding shares - to establish a long-term relationship with corporations as part of the keritsu system of industrial organization. This was an important component of the main bank system in which a financial institution, usually a city bank, played a leadership role in the company group. In the 1980s the main bank system declined in importance as firms found alternative sources of funding and developed other methods to inform potential lenders of their creditworthiness. However, banks continued to hold large amounts of corporate equities, and the capital gain accumulated on these securities over the years was referred to as "latent" or "hidden" capital.

Japanese banks sought to have the latent capital counted toward the new BIS capital-asset requirements established in 1988 for banks that engaged in international activities. As a result of intense lobbying, they were permitted to count 45 percent of their latent capital as part of tier II capital requirements. This greatly enhanced bank capital in the bubble phase of the economy and contributed to the run-up in real estate prices as banks expanded into the real estate sector either directly or indirectly through their jusen subsidiaries.

Unfortunately, the process also worked well for latent capital losses. The collapse of equity prices made it difficult for banks to meet capitalasset requirements and in order to maintain adequate capital-asset ratios, banks slowed the growth of assets (loans and investments) and generated a bank credit crunch. This was the only way banks could meet their capital-asset requirements, since they were unable to raise capital through bank equity and/or subordinate debt.

\section{The role of the PSS and FILP}

The PSS and FILP are major components of the Japanese economy, measured by their size relative to both the economy and the financial system. Postal deposits held in about 25,000 post offices throughout the country 


\section{Thomas F. Cargill}

represent 35 percent of total deposits. The PSS also sells life insurance, and postal life insurance represents 30 percent of the life insurance market. The PSS continued to expand after 1976 despite an official policy of liberalization.

The FILP system obtains the majority of its funds from the PSS. The FILP is a flow of funds budget developed along with the government's general budget designed to collect funds from the private sector through postal deposits, life insurance premiums and other sources, and then transfer those funds to a large number of government banks, government enterprises, and government corporations referred to as FILP entities. Prior to April 1, 2001, postal deposits and postal life insurance premiums, together with other sources of funds, were transferred directly to the Trust Fund Bureau of the Ministry of Finance, which were then distributed through the FILP budget to the FILP entities.

The PSS and FILP have only recently been the focus of institutional redesign. Starting April 1, 2001, postal deposits and life insurance premiums are no longer transferred to the Trust Fund Bureau, but are now managed by the PSS, which as of April 1, 2003 became a public corporation. The FILP entities either sell their own agency securities or participate in FILP bonds issued by the Ministry of Finance in the open market. While these reforms may set in motion changes that will fundamentally affect the PSS and FILP, it is far too early to be optimistic. The PSS and FILP embody the key elements of the old financial regime, and as such have been resistant to reform, ${ }^{8}$ and in turn because of their size have contributed to the overall inefficiency of Japan's economy.

These institutions are important aspects in understanding Japan's resistance to reform. First, their size, their interactions with almost every sector of the Japanese economy, and their importance in supporting the LDP constitute critical resistance factors to reform and recovery. Japan cannot return to sustained economic growth without redesigning its financial institutions to raise the return on the high saving rate: however, the fact that a large part of the public's savings are absorbed by the PSS and FILP and allocated to low return and sometimes negative return projects is a serious restraint on recovery. Second, the expanding influence of these institutions during the past three decades attests to the view that Japan's financial liberalization was more rhetoric than substance and to the difficulty of shifting from the old to the new financial regime.

\section{Japan does not perceive a crisis}

There is an interesting comparison between Korea and Japan that suggests another country-specific restraint on reform. Prior to the Asian Financial Crisis Korea had long been criticized for its inefficient financial institutions, irrational allocation of credit, and large nonperforming loan problem that had emerged in the 1970s. Korea devoted some attention to 
these concerns and officially adopted numerous financial liberalization measures in the 1980s. Despite some progress, the general assessment up to 1997 was that financial liberalization was even more rhetoric than substance compared to Japan. Korea's efforts were designed to be just sufficient to secure acceptance into the OECD, which Korea achieved in 1995, but not critical enough to change the basic structure of the financial system. Korea, like Japan, found it difficult to accept the necessity to make fundamental changes when their economy has achieved so much success in such a short period of time. Korea's financial institutions more than those of any other Asian country were closest to the prewar Japanese financial institutions organized around the zaibatsu.

In late 1997 when Korea's economy and financial system collapsed, policymakers correctly perceived a crisis situation and one that required decisive action. As such, in 1998 and 1999 Korea moved swiftly to bail out private banks, permit foreign investment in banks, and reform corporate governance. Central bank policy was constrained to prevent both inflation and deflation by adopting a formal inflation-target framework (Cargill 2005a). The economy recovered rapidly and by 2000 Korea had appeared to return to sustained economic growth. Thus, the crisis environment provided an incentive to initiate fundamental institutional redesign. It should be noted in passing, that the United States also allowed inefficiencies to accumulate in the financial system for almost 15 years from 1965 to 1980 until a crisis environment in 1980 induced fundamental institutional redesign (Cargill and Garcia 1985).

Japan does not perceive itself in a crisis situation, with the possible exception of the turbulent period from the fourth quarter of 1997 to early 1999. Japan's lost decade is more one of lost potential, than of actual decline. Income per capita is now higher than in 1990. Japanese homeownership is broad-based, and while real estate prices have declined as much as 60 percent, the turnover rate of homeownership is low. Despite a Nikkei Index at about 10,900 as of early 2005 compared to almost 40,000 in December 1989, household financial wealth is large, with much of it held in the form of risk-free postal deposits that, even though they pay a low nominal rate (less than 0.5 percent), provide a real rate of return of 1 to 2 percent because of deflation. The large corporations have shielded themselves from Japan's inefficient financial institutions, shifting much of their production and financial operations outside of Japan; that is, they have "opted out" (Schoppa 2001) of providing political pressure to reform the system. The LDP, for the time being, continues to benefit politically from the support of banks that do not wish to see a more aggressive resolution of the nonperforming loan problem, from the support of corporations and business firms that do not wish to see a more aggressive resolution of the nonperforming borrower problem, and from the PSS and FILP that do not wish to see a reduction of government financial intermediation. At the same time, the deadweight loss has not yet been perceived 
by the public to be serious enough to demand change. Japan is not in danger of a currency crisis since it has virtually no external debt, international reserve assets are large, and the world continues to purchase Japanese goods. Thus, in many respects, the household, business, and political sectors do not see the current situation in crisis terms and that in itself is a constraint on reform. There is one possible exception when Japan did see itself in crisis. The economic and financial turbulence following the failures of Hokkaido Takushoku Bank and Yamaichi Securities Company in November 1997 and the sharp decline in real GDP in 1998 led to a LDP defeat in July 1998 Upper House elections, which forced Prime Minister Hashimoto to resign and the government to take more aggressive action. Unfortunately, this sense of urgency passed.

\section{General or global factors that provide resistance to reform}

Much resistance to reform stems from country invariant factors, and in this regard attention needs to be directed to central bank policy. ${ }^{9}$ Bank of Japan policy outcomes in the 1990s represent a major restraint on reform and recovery. To understand the role of the Bank of Japan as a restraint fact, the following five issues are considered: first, the overemphasis on external considerations that led to the two major policy errors prior to 1989; second, tight monetary policy in the 1990s; third, explanations of why the Bank of Japan was not sufficiently expansionary in the 1990s, especially the second half of the 1990s; fourth, why deflation is a serious problem and the feedback between central bank policy and deflation that make reversing the deflationary process more difficult over time; and fifth, recent developments through early 2005 in Bank of Japan policy.

\section{Policy errors prior to 1989}

The performance of the Bank of Japan during the past decade stands in contrast to an impressive record of monetary policy in the postwar period, marked by only two identifiable policy errors: expansionary monetary policy in the early 1970s and in the second half of the 1980s. Both policy errors were rooted in an attempt to limit yen appreciation and both can be accounted for without placing extensive blame on the Bank of Japan.

In the first instance, the Bank of Japan was directly under the influence of the Ministry of Finance, which delayed shifting to tighter monetary policy to slow inflation in 1972 and 1973 as a result of past easy monetary policy. The Bank of Japan expanded the money supply in the late 1960s and early 1970s to maintain high economic growth into the 1970s. After 1970, the Bank of Japan also expanded the money supply to limit yen appreciation as the fixed exchange rate system was collapsing. The result was rapid inflation and while the Bank of Japan had been willing to expand the money supply in the past, the Bank in late 1972 wanted to shift 
to tight monetary policy to combat inflation. The Bank of Japan, however, was prevented by the Ministry from shifting to tight monetary policy and, as a result, inflation increased rapidly before the Bank shifted to tight monetary policy in late 1973.

In the second instance, the Bank of Japan pursued intervention in the foreign exchange market to limit yen appreciation or its equivalent, and to support the dollar in the context of an expanding and low inflation economy. The Bank of Japan's mistake was to believe it could have a "free lunch" - limit yen appreciation with no adverse effect on the domestic economy, the same error made in the early 1970s. Increasing concern with consumer prices in 1989 as well as asset inflation in equity and real estate prompted the Bank of Japan in May 1989 to shift to tight monetary policy. As an indication of the degree of political independence achieved by the Bank of Japan, the increase in the discount rate was openly opposed by the Ministry of Finance. In the early 1970s, the Bank of Japan was more accommodative to the wishes the Ministry.

\section{Policy errors in the 1990s}

Bank of Japan policy after 1989, however, cannot be so easily defended. It became a serious constraint on reform and recovery in two ways: first, by pursuing tight monetary policy after 1989 for too long a period; and second, by not pursuing easy monetary policy after 1994 aggressively enough and allowing the price level to decline. There is general agreement outside of the Bank of Japan that monetary policy in the 1990s was tight (McCallum 2003).

The Bank of Japan continued tight monetary policy until 1994, well after it became obvious that the decline in economic activity was more serious than previously experienced since re-industrialization commenced in 1950. This period deepened the economic and financial distress in Japan and exacerbated the effects of the collapse of asset prices on balance sheets. Better monetary policy during the first part of the 1990s, however, would not likely have made much difference in Japan's willingness to redesign the financial system and aggressively deal with the nonperforming loan problem.

First, the majority of policymakers did not view the economic and financial problems as very serious. In fact, the economy began to recover in 1995 and 1996 and appeared to justify the forgiveness and forbearance policy adopted in the early 1990s. Second, in 1995 major institutional change was in progress - the official closing of a number of small depository institutions, the redesign of the Deposit Insurance Corporation (DIC), the closing of the jusen industry, and the establishment of two agencies to dispose of nonperforming loans of the jusen industry (Housing Loan Administration Corporation) and banks and credit cooperatives (Collection and Resolution Bank). As far as policymakers were concerned, these policies were sufficient to deal with the financial distress. 


\section{Thomas F. Cargill}

The reluctance to make more fundamental changes appeared justified by events in late 1995 and 1996. Monetary policy shifted to ease, the economy improved, equity prices began to recover, and the growth of the nonperforming loan problem slowed. In fact, there was sufficient confidence about resolving the economic and financial distress that the newly elected Hashimoto government launched the Big Bang approach to financial redesign in November 1996. Thus, while Bank of Japan policy could have pursued a less restrictive policy in the first half of the 1990s, better policy outcomes would not have made much difference to Japan's willingness to reform. In fact, it probably would have provided even more resistance to reform since economic recovery would have likely occurred earlier.

The second part of the restraint period with regard to Bank of Japan policy, however, is more fundamental and serious. After 1997, there were few in Japan who argued that the old regime could continue for much longer. Japan could no longer argue that financial distress had not reached the center of the financial system. The failures of Hokkaido Takushoku Bank and Yamaichi Securities in late 1997 and the nationalization of the Long Term Credit Bank of Japan and the Nippon Credit Bank in late 1998 were clear manifestations of the old regime's failure.

By any reasonable standard Japanese monetary policy in the second half of the 1990s has been excessively tight despite arguments to the contrary by the Bank of Japan. The decline in prices and increase in real interest rates are clear indications of tight monetary policy. While nominal interest rates were at historical lows in early 2003, the real rate of interest had exhibited an upward trend since 1996.

\section{Why has the Bank of Japan permitted deflation?}

It is difficult to account for the Bank of Japan's behavior, especially given the lessons learned from the history of central bank policy during the 1930s. Cargill (2001b) argued that the Bank of Japan was making the same mistake made by the U.S. Federal Reserve in the early 1930s and was using similar rationalizations employed by the 1930s Federal Reserve as to why more aggressive monetary policy could not be pursued. Five explanations offer some insight into the Bank of Japan's position.

First, the Bank of Japan has argued deflation was not an outcome of monetary policy and that the zero-interest rate policy was as much as the Bank of Japan could contribute to reversing the decline in prices. The Bank of Japan has attributed declining prices to structural factors such as the increased role of foreign competition in Japan, Chinese imports (Noland and Posen 2002), and the failure to resolve the nonperforming loan and borrower problems. These explanations, however, stand in contrast to an extensive literature linking monetary policy to long-term price movements, and as such have found little support outside of a few circles in Japan. 
Second, Cargill et al. (2000) argue that the Bank of Japan is caught in an "independence" trap and became overly conservative. Central bank independence in 1998 was an unexpected event, despite lobbying by the Bank of Japan to have the 1942 Bank of Japan law revised. Perhaps the Bank of Japan became overly conservative and timid in conducting monetary policy so as not to inflate the economy as it had done in the second half of the 1980s. Another policy error might result in the loss of the newly achieved independence.

Third, the Bank of Japan resisted calls for more aggressive policy, at least up to mid-2002 when the Bank shifted toward more ease. This was not so much because the Bank of Japan did not believe more aggressive policy was needed, but because to give in to outside pressure would appear to be acting less than independent. To borrow a phrase attributed to Paul Samuelson, ${ }^{10}$ the Bank of Japan has become a "prisoner of its own independence." That is, the Bank of Japan is more concerned with maintaining a perception of independence and thus rejects outside criticism and suggestions, especially if they come from the Ministry of Finance. To pay serious attention to outsiders, even if they offer good advice, is seen as giving in to an outside "mob" and thus the existing policy becomes even more entrenched. This is another manifestation of the independence trap argument.

Fourth, Cargill and Parker (2003a) argue there is a "war of attrition" between the Bank of Japan and the rest of government, especially the Ministry of Finance, that has provided an incentive for the Bank of Japan to resist more aggressive monetary policy. Japan's government has generally been reluctant to impose the type of penalty function on the banking system and the nonfinancial sector required to resolve the nonperforming loan and borrower problem. The Ministry would rather have the Bank of Japan, through monetary growth, support the banking system and economy as part of a forgiveness and forbearance strategy. The Ministry supports the banking system through the budget, which in turn can be more easily financed with easy monetary policy. The Bank of Japan resists using monetary policy to support a continued policy of forgiveness and forbearance and is reluctant to pursue nontraditional policies until it is convinced the government is serious about resolving the nonperforming loan problem. Thus, the tight monetary policy might be the outcome of the Bank of Japan's view that until serious structural changes are made, aggressively easy monetary policy will only postpone resolution of the nonperforming loan problem and increase its ultimate economic and political cost.

Fifth, the Bank of Japan is concerned that more aggressive monetary policy will be used to support an already high level of government debt independent of its concerns over structural reform of the financial system. The Bank has a long memory and does not wish to repeat the events of the 1930s, when monetary policy was used to support large government deficits which resulted in high inflation. 


\section{Thomas F. Cargill}

\section{Why deflation is a problem and creates the potential for a central bank discontinuity or liquidity trap}

Deflation has recently come to be recognized as a serious macroeconomic problem beyond the experiences of Japan. ${ }^{11}$ In May 2003 the Federal Reserve and European Central Bank expressed concern about the potential for deflation. Krugman (1998) reintroduced the concept of the liquidity trap to account for what is happening in Japan and what is likely to become a more general problem of "depression economics" elsewhere (Krugman 2002).

Cargill and Parker (2003b, 2004a, 2004b) discuss the sources of deflation, the effects of deflation, and the relationship between deflation and monetary policy from an institutional, theoretical, and econometric perspective. Their discussion can be summarized in the following steps.

First, since deflation has been a rare event in the postwar period, contracts are likely to be adjusted much more slowly in response to a deflation of $x$ percent than an inflation of $x$ percent. Second, the nominal rate of interest is bounded from below by zero; hence, deflation increases the real rate of interest and reduces investment spending. Third, deflation increases the cost of servicing debt and increases bankruptcy, further reducing spending and weakening balance sheets of financial institutions. This is a variation of Fisher's (1933) "debt-deflation" process described 70 years ago in the context of the decline in economic and financial activity in the United States from 1929 to 1933 . The increased bankruptcy rate reduces the money multiplier as banks become less willing to lend. Fourth, even perfectly-expected deflation may reduce current consumption due to the asymmetric effect on future prices and the real interest rate, as consumers wait for cheaper prices in the future. Specifically, since the nominal interest is bounded from below by zero, deflation increases the real interest rate and provides incentives to save. Fifth, deflation changes the relative prices between money and commodities and tends to increase the demand for money, making it more difficult to restore expectations of price increases by monetary policy.

Deflation generates a discontinuity for monetary policy or a liquidity trap in the sense that deflation shifts the demand for money upwards (velocity declines), reduces consumption, reduces investment, and reduces the money multiplier, thereby reducing the ability of the central bank to reverse course. This is a different type of liquidity trap than the standard textbook Keynesian case. In this case, the central bank is responsible for the upward shift in money demand and, in turn, has the ability to reverse the liquidity trap by aggressive monetary ease. Hence, the phrase "discontinuity in monetary policy" might be more appropriate than liquidity trap. Estimates of the demand function for money in Japan using quarterly data find a significant (at conventional levels of confidence) upward shift in money demand and downward shift in the consumption function (annual 
data) in the 1990s that can be statistically related to the decline in prices. Cargill and Parker also present evidence that the money multiplier has declined along with the price level.

\section{Recent policy changes}

In the later part of 2001 the Bank of Japan shifted to a more aggressive monetary policy by adopting quantitative targets for reserves instead of focusing on the call rate target. The call rate was already close to zero. The impact on the monetary base was immediate. The monetary base increased 7.6 percent in 2000; however, starting in July 2001, it increased at an annual rate of 10 percent, and since the end of 2001 the monetary base has been increasing at an annual rate of between 25 and 30 percent. This shift in policy was a direct result of increasing criticism from the LDP and Koizumi, and the realization by the Bank of Japan that it would be forced to accept an explicit inflation target and hence lose its newly found legal independence unless it showed more willingness to increase liquidity.

In order to maintain its legal independence, the Bank of Japan may have been willing to give up some of its substantive independence in other areas. News reports (Business Times, March 29, 2003) indicate that early in 2003, before the final decision was made on its new Governor, the Bank of Japan promised a more cooperative attitude on dealing with troubled financial institutions. This may also account for why Koizumi, instead of appointing a "deflation fighter" as promised, appointed Toshihiko Fukui (a former deputy governor of the Bank of Japan) to replace outgoing Governor Masaru Hayami.

There is a dynamic in process between the Bank of Japan and the government, in which the Bank of Japan might be more aggressive with monetary policy; however, in an effort to protect its new-found independence, the Bank of Japan may at the same time become a more active partner in forgiveness and forbearance so that a more aggressive policy will compound Japan's structural problems. Irrespective of this potential, the Bank of Japan needed to be more expansionary to reverse deflationary expectations, which were doing serious macroeconomic damage and impeded structural reform. The macroeconomic performance of the economy improved after the Bank of Japan shifted policy. The deflation rate declined and real GDP increased in 2003. Governor Fukui made it clear that the Bank of Japan will not purchase bank equities to provide support for the banking system as advocated by some Diet members, but will focus on eliminating deflation. The Bank of Japan, however, still expresses concern over the more aggressive monetary policy, and has recently raised issues about its capital base and the possibility that its capital would be inadequate to carry on monetary policy operations at some point in the future (Cargill 2005a). 


\section{Thomas F. Cargill}

\section{The difficulty of institutional change: the PSS and FILP ${ }^{12}$}

Until Koizumi became prime minister in April 2001, the PSS and FILP were not widely known institutions outside of Japan. Koizumi attracted attention to these institutions because he had been a long-time critic and advocated privatization of the PSS. The PSS and FILP were an important and large part of the old financial regime. Despite two decades of financial liberalization, these institutions became more prominent and were not reformed. Postal deposits now represent the largest component of total deposits at any time in the postwar period and the FILP budget represented about 10 percent of GDP as of 2001 (Cargill and Yoshino 2003a).

The PSS and FILP avoided reform because they were supported by the household sector, small businesses, local and central government, and politicians - especially the LDP. Despite overwhelming evidence that the lack of reform of the PSS and FILP limited the liberalization process, there was little official attention directed toward institutional redesign of these institutions. They were not even mentioned in the 1996 Big Bang announcement and subsequent legislation in 1997, with the minor exception of some changes in government corporation accounting. The PSS complicated Japan's government deposit guarantee system, provided incentives to transfer private bank deposits to the PSS whenever the public became concerned about the condition of the banking system, and in general made it difficult for banks and life insurance companies to compete in the household market. In fact, the PSS in the early part of the 1990s encouraged disintermediation by advertising the safety of postal deposits over private bank deposits. ${ }^{13}$ There has been little discipline or monitoring of the funds distributed to various sectors in the economy through the FILP entities. Doi and Hoshi (2003) examined the extent of the nonperforming loan problem embedded in the FILP system and concluded that nonperforming loans represent 16 percent of GDP.

Major reform was initiated in 2001 when the PSS was no longer required to transfer funds directly to the Ministry of Finance, and for all practical purposes became a stand-alone government bank managing its own funds, and the FILP entities were required to obtain funding by selling agency securities and/or participating in government debt. The PSS remained an important source of funds to the FILP, however, since at least 80 percent of its assets are to be allocated to safe assets such as government bonds.

As of April 1, 2003 the PSS became a public corporation; however, for all practical purposes it remains a government bank. The system is now referred to as the Japan Postal Agency or Japan Post (Cargill and Yoshino 2003b). The Japan Post, however, remains a government bank and complicates Japan's deposit insurance reform in two ways. First, it encourages disintermediation of funds from private bank deposits to postal deposits in times of financial distress; second, in the absence of financial stress, postal deposits will likely establish a dual system of deposit guarantees in Japan. 
In late 2004 Koizumi received Cabinet approval for a plan to privatize the Japan Post, starting in 2007 and ending in 2017. The plan was defeated in the Lower House of the Diet on August 8, 2005, and Koizumi dissolved the Lower House and called a "snap" election for September 11, 2005. Koizumi and the more liberal wing of the LDP achieved a major victory, increasing its majority position. On October 14, 2005 the previously rejected plan became law with only minor revisions. The "privatization" plan is more in name than substance, and many observers regard the plan as generating as many problems as it solves. Cargill and Scott (2005) provide a comprehensive review of the issues up to just before the "snap" election.

\section{Disintermediation}

During periods in the 1990s, when people were concerned about the financial stability of the private banking system, they transferred funds from private depository institutions into postal deposits. Why did this happen, considering that private bank deposits were insured up to ten million yen and postal deposits were limited to ten million yen? Because postal deposits were perceived by the public as direct government debt, and therefore fully guaranteed, while the DIC was perceived to be incapable of providing the ten million yen guarantee beyond only a small number of depository institutions. It should not go unnoticed that disintermediation of funds from bank to postal deposits after 1996 occurred in the context of a temporary complete deposit guarantee that had been in place since late 1995 and set to expire on April 1, 2001. Thus, even with a complete guarantee, the PSS induced disintermediation.

U.S. history has a similar episode when a postal saving system led to disintermediation. This happened in the early 1930s, when the financial system was in distress. O'Hara and Easley (1979) and Kuwayama (2000) document how bank failures encouraged disintermediation of funds from private banks to the U.S. postal system, which increased the stress on private banks and contributed to the collapse of the U.S. banking system. Deposit insurance did not exist prior to 1934, and as a result postal deposits were viewed as less risky than bank deposits in the context of about 10,000 bank failures from 1929 to 1933 in the United States.

While the U.S. version of the PSS has long since disappeared, Japan's PSS remains a large part of the country's flow of funds. Hence, its role as a government bank remains a potential problem as Japan moves toward a U.S.-style deposit insurance system. Any sign of financial distress in the banking system, especially among the smaller banks and cooperatives, is likely to induce disintermediation from bank deposits to postal deposits. 


\section{Thomas F. Cargill}

\section{Dual system of government deposit guarantees}

Even in a more stable economic and financial environment, Japan will find it difficult to establish a meaningful deposit insurance system as long as the Japan Post remains a government bank. In terms of perceived deposit guarantees by the public, the Japan Post and large banks stand at one end of the financial system. Postal deposits are regarded as government debt, so holders of those deposits are not concerned about the underlying financial condition of the DIC or of any separate government insurance agency to fulfill the deposit insurance limit. Though postal deposits are limited to ten million yen, the same level as the insurance limit on private deposits, the two types of deposits are not likely to be viewed as equivalent by the typical Japanese deposit holder, especially bank deposits at smaller institutions. The large Japanese banks operate with a complete deposit guarantee, irrespective of deposit insurance. This feature of Japanese finance is known as "Too Big to Fail," and while the government may declare large banks insolvent (like Japan Long Term Credit Bank, and Nippon Credit Bank in late 1998), depositors anticipate their deposits will be protected beyond the deposit insurance limit.

At the other end of the financial system stand the large number of relatively small credit cooperatives and banks, whose deposit guarantee status is less certain. In the view of the typical deposit holder, postal deposits will likely be considered safer than the deposits of the smaller depository institutions. This complicates the government deposit guarantee system and puts smaller private depository institutions at a competitive disadvantage compared to the large private banks and the PSS.

Hence, the Japan Post complicates Japan's deposit guarantee system by supporting a dual system. Postal deposits and deposits at the large private banks may be considered equivalent, but postal deposits and deposits at smaller depository institutions may be viewed differently by the public, to the disadvantage of the smaller depositories.

There are many arguments for privatizing the Japan Post. Few have recognized so far, however, that one of the most important arguments is that privatizing postal savings is a critical prerequisite in reforming deposit insurance, which in turn is a necessary part of financial redesign in general.

Progress toward deposit insurance reform has been slow and less than promised. When the complete deposit guarantee was announced by the Ministry of Finance in late 1995, it was set to expire on April 1, 2001 when the ten million yen deposit insurance limit would become effective again for all deposits. The expiration date was extended twice, once to April 1, 2002, and then to April 1, 2003. In December 2002, the new deposit insurance system was announced. Effective April 1, 2003, the ten million yen limit was re-imposed on time and savings deposits, the complete guarantee remains in place on all current and ordinary deposits (transactions deposits) until March 31, 2005, at which time, non-interest bearing current 
or settlement deposits will continue to be subject to a complete deposit guarantee. These deposits represent about 10 percent of transactions deposits. This falls somewhat short of reducing government deposit guarantees in Japan.

\section{Was the Japanese financial system sustainable?}

It is important for Japanese policymakers not only to recognize the restraints to institutional redesign, but also to recognize the weak foundation of the postwar success on the old financial regime. That is, the old regime was not sustainable because it functioned in an environment that could not be maintained despite Japan's impressive growth record. This is an important part of the attitudinal change needed to more aggressively pursue institutional redesign. Krugman (1994) was one of the first to discuss this issue in his controversial paper on the sustainability of economic growth in Asia or the sustainability of the so-called "Asian miracle." Krugman's argument focused on the diminishing returns resulting from large applications of capital and labor in the absence of significant technological advances. Two additional considerations can be identified that further suggest the Japanese regime was unsustainable.

First, the financial system of Japan required a special set of circumstances to function: a limited number of channels of finance, an ability to administer and control financial transactions, consensus on national goals, international isolation, and rapid rates of economic growth. Rapid growth was required to mask inherent inefficiencies in the system and to placate those groups (households and small businesses) with limited access to the private financial system. These conditions were not sustainable. At a minimum, the success of the state-directed financial regime in achieving high rates of economic growth ensured the country would increasingly come into contact with world markets and political forces and thus would be forced to liberalize.

Second, the Japanese financial system possessed an inherent flaw that limited technological innovation, and at some point would be unable to support sustained economic growth. The emphasis on mutual support, minimization of risk, and limiting bankruptcy ensured that inefficient firms were not eliminated, and over time inefficient capital would accumulate and increasingly become a dead weight on future economic growth. Cargill and Parker (2002) present a development model to illustrate how statedirected financial regimes with an emphasis on limiting bankruptcy may generate rapid growth for a period of time, but ultimately generate lower growth rates as the deadweight loss from inefficient capital accumulates. The model also illustrates the high transactions cost required to shift from a state-directed to a market-directed financial regime. 


\section{Demographic changes - the trump card}

Japan does not see itself in crisis, especially since recovery commenced in 2003, nor are there sufficient sectors of the economy that see significant institutional redesign worth the transition costs. Political leadership as of early 2005 has failed to generate the support for the costly process of resolving the nonperforming loan and nonperforming borrower problems. Koizumi, more than any other Prime Minister since 1990, has attempted to move more aggressively forward. The FSA has promised a far more aggressive and painful resolution of the financial distress under new leadership as of late 2002. The Bank of Japan has shifted to a more aggressive monetary policy, and with a new Governor appears to be making progress toward reversing deflationary expectations and reestablishing central bank credibility in Japan. Developments in 2003 and 2004 suggest cautious optimism. At the same time, there have been several periods of recovery in the past decade, followed by decline.

The ultimate trump card for Japan will be a radical change in demographics. Population is projected to commence declining about 2008 and the dependency ratio (non-working aged population to working-aged population) is projected to be the largest among the industrialized countries. Simple national income arithmetic suggests that unless Japan is able to offset these demographic changes with higher labor productivity, the standard of living in Japan will decline significantly.

It is widely recognized in Japan that labor efficiency is directly related to the efficiency with which Japan allocates its saving. The issue for Japan is not a lack of savings, but rather an inefficient distribution system for allocating savings. The demographic changes may be what is finally needed to convince Japan that a real crisis is present.

\section{Conclusion}

Japan has completed one lost decade in terms of foregone economic and financial development. The start of the new century was not optimistic as the economy slowed and financial distress increased in 2001 and 2002; however, Japan appears to have started a recovery process in 2003. But there are some signs that recovery slowed in 2004. Thus, it is too early to say that Japan has began a process of sustained recovery from over a decade of economic and financial distress.

The malaise of the 1990s is the direct result of a reluctance to depart from the old system that served Japan well throughout the postwar period and because Japan does not perceive itself in a crisis. Japan's long period of economic and financial malaise is not one of lack of understanding or lack of resources. Japanese policymakers have a clear understanding about what happened and the institutional redesigns needed to return the economy and financial system back to sustained growth and stability. It is 
also clear that Japan has the intellectual and financial resources to implement the needed policies.

Ultimately, institutional redesign is a matter of will and political leadership. Koizumi has provided more effective leadership than any previous prime minister since the burst of the bubble economy in 1990. Koizumi supported more aggressive handing of nonperforming loans, pressured the Bank of Japan to shift to a more expansionary policy, and initiated major structural reforms of postal savings. Koizumi's influence is waning, however, and he faces considerable resistance to the reforming of the Japan Post. His term ends in late 2006 and it is likely that a less reformminded administration will assume power, especially if even a weak recovery continues into 2006 .

\section{Acknowledgments}

The author expresses appreciation to the participants of the January 5-6, 2003 Conference, Institutional Change in Japan: Why it Happens, and Why it Doesn't, and especially Jack P. Suyerhond for helpful comments on an earlier draft. All remaining errors are the responsibility of the author. This paper extends Cargill (2001a), which reviewed the evolution of private and public financial institutions in postwar Japan. This chapter focuses on why economic and financial distress continues in Japan and, like the earlier paper, draws on previous work, but places the discussion in the context of a taxonomy of financial reform and bifurcates resistance factors into country-specific and general categories.

\section{Notes}

1 Cargill, Hutchison, and Ito (1997 and 2000) review the postwar financial and monetary developments in Japan, with emphasis placed on the past two decades. Other reviews of Japan's recent economic and financial performance include: Blomström, Gangnes, and La Croix (2001); Freedman (1999 and 2001); Hoshi and Patrick (2000); and Mikitani and Posen (2000).

2 The process of institutional change has been discussed much in the literature and the views in this paper are similar to those in Becker (1983), which provides a theoretical model of how competition among different groups influences the political process, generating institutional change. These views are also similar to the "public choice" literature that models public decisionmaking as a utility maximization process that may generate an equilibrium for the decision-making authority inconsistent with the general welfare of the society. Additional references on the process of institutional change are found in Kawaura and La Croix (2003).

3 Other reasons could be offered, such as each country's importance in the world economy, each country's importance in the Pacific Basin region, and the special cultural and historical relationship that exists between the three countries.

4 This was the major theme of Cargill and Royama (1988), which subsequent events proved to be overly optimistic.

5 Feldman (1986), Cargill and Royama (1988), and Cargill, Hutchison, and Ito (1997 and 2000) and the extensive list of references in each of these works. 


\section{Thomas F. Cargill}

6 The gensaki market is the repurchase market in government securities that unofficially existed from about 1965 to 1976 became an official market in 1976. The Ministry of Finance had permitted the unofficial market for over a decade as part of a quid pro quo between the Ministry and the securities industry to absorb government debt at above market prices.

7 This comment was made by Joseph Bisignano, Bank for International Settlements.

8 Cargill and Yoshino (2003a) provide a comprehensive overview of the PSS and FILP in postwar Japan. An update on developments as of mid-2003 is provided in Cargill and Yoshino (2003b).

9 Fiscal policy in Japan could also be singled out as a general problem. The numerous fiscal stimulus packages have done little to resolve the economic and financial distress. Much of the spending has been wasted on pork barrel projects and much of the stimulus has been in the form of loan guarantees. The only real impact of fiscal policy has been to leave Japan with a large central government deficit and government debt. Despite the problems created by poorly designed fiscal policy, monetary policy remains the most serious problem.

10 See Cargill (2001c) for more detail on central bank independence as well as more discussion regarding Samuelson's comment.

11 Burdekin and Siklos (2004) provide an overview of the deflation issue.

12 The material in this section is drawn directly from two research reports published by the Federal Reserve Bank of San Francisco (Cargill and Yoshino 2001 and Cargill 2002).

13 Cargill and Yoshino (2003a) and Okina (2000) provide evidence of the disintermediation problem.

\section{Bibliography}

Bank of Japan. Monthly Report of Recent Economic and Financial Developments. January 2005.

Becker, Gary S. "A Theory of Competition Among Pressure Groups for Political Influence.” Quarterly Journal of Economics. 98 (August 1983): 371-400.

Benston, George J. and George G. Kaufman. "FDICIA After Five Years." Journal of Economic Perspectives. 11 (Summer 1997): 137-58.

Blomström, Magnus, Byron Gangnes, and Sumner La Croix (eds). Japan's New Economy. Oxford: Oxford University Press, 2001.

Burdekin, Richard and Pierre Siklos. "Fears of Deflation and Policy Responses Then and Now." In Pierre Siklos and Richard Burdekin (eds), Deflation. Cambridge: Cambridge University Press, 2004.

Business Times Online Edition, "Koizumi, BOJ in Secret Deal to Rescue Economy." March 29, 2003.

Cargill, Thomas F. "Korea and Japan: End of the 'Japanese Financial Regime'.” In G. G. Kaufman (ed.), Bank Crises: Causes, Analysis and Prevention. London: JAI Press, 1998.

Cargill, Thomas F. "Central Banking, Financial, and Regulatory Change in Japan." In Magnus Blomström, Byron Gangnes, and Sumner La Croix (eds), Japan's New Economy. Oxford: Oxford University Press, 2001a.

Cargill, Thomas F. "Monetary Policy, Deflation, and Economic History: Lessons for the Bank of Japan." Monetary and Economic Studies (Special Issue), 19 (February 2001b): 113-34. 
Cargill, Thomas F. "Financial Liberalization, Asset Inflation, and Monetary Policy in Japan." In George G. Kaufman (ed.), Asset Price Bubbles: Implications for Monetary and Regulatory Policies. Amsterdam: JAI Press, 2001c.

Cargill, Thomas F. "Japan Passes Again on Fundamental Financial Reform." FRBSF Economic Letter. Federal Reserve Bank of San Francisco. September 27, 2002.

Cargill, Thomas F. "Is the Bank of Japan's Financial Structure an Obstacle to Policy?" IMF Staff Papers 52(2) (2005a) 311-34.

Cargill, Thomas F. "A Tale of Two Monetary Policies - Korea and Japan." FRBSF Economic Letter. Federal Reserve Bank of San Francisco. Forthcoming in 2005b.

Cargill, Thomas F. and Gillian Garcia. Financial Reform in the 1980s. Stanford, CA: The Hoover Institution Press, 1985.

Cargill, Thomas F., Michael M. Hutchison, and Takatoshi Ito. Financial and Central Bank Policy in Japan. Cambridge, MA: The MIT Press, 2000.

Cargill, Thomas F. and Elliott Parker. "Asian Finance and the Role of Bankruptcy: A Model of the Transition Costs of Financial Liberalization," Journal of Asian Economics. 13 (2002): 297-318.

Cargill, Thomas F. and Elliott Parker. "Japanese Economic Structures and Finance: Characteristics and Causes of the Current Slow Down." In P. C. Padoan, P. Brenton, and G. Boyd (eds), Structural Foundations of International Finance, Cheltenham, UK: Edward Elgar, 2003a.

Cargill, Thomas F. and Elliott Parker. "Why Deflation is Different." Central Banking, August 2003b: 35-42.

Cargill, Thomas F. and Elliott Parker. "Price Deflation, Money Demand, and Monetary Policy Discontinuity: A Comparative View of Japan, China, and the United States," North American Journal of Economics and Finance. 15(1) (2004a): 125-47.

Cargill, Thomas F. and Elliott Parker. "Price Deflation and Consumption: Central Bank Policy and Japan's Economic and Financial Stagnation," Journal of Asian Economics, June 2004b: 493-506.

Cargill, Thomas F. and Hugh Patrick, "Response to Financial and Economic Distress: South Korea and Japan.” Korea's Economy 2005. Korea Economic Institute of America, forthcoming in 2005.

Cargill, Thomas F. and Shoichi Royama. The Transition of Finance in Japan and the United States. Stanford, CA: The Hoover Institution Press, 1988.

Cargill, Thomas F. and Hal S. Scott. "Japan's Postal Savings Showdown," Financial Regulator 10(2), September 2005: 78-86.

Cargill, Thomas F. and Naoyuki Yoshino. "Japan's New Prime Minister and the Postal Savings System.” FRBSF Economic Letter. Federal Reserve Bank of San Francisco. May 18, 2001.

Cargill, Thomas F. and Naoyuki Yoshino. Postal Savings and Fiscal Investment in Japan. Oxford: Oxford University Press, 2003a.

Cargill, Thomas F. and Naoyuki Yoshino. "Reforming Japan: The Long Haul." Financial Regulator. 8 (June 2003b): 61-7.

Cargill, Thomas F., Michael M. Hutchison, and Takatoshi Ito. The Political Economy of Japanese Monetary Policy. Cambridge, MA: The MIT Press, 1997.

Doi, Takero and Takeo Hoshi. "Pay for the FILP." In Magnus Blomström, Jennifer Corbett, Fumio Hayashi, and Anil Kashyap (eds), Structural Impediments to Growth in Japan. Chicago, IL: University of Chicago Press, 2003. 


\section{Thomas F. Cargill}

Feldman, Robert Alan. Japanese Financial Markets: Deficits, Dilemmas, and Deregulation. Cambridge, MA: The MIT Press, 1986.

Fisher, Irving. "The Debt-Deflation Theory of Great Depressions." Econometrica. 1 (October 1933): 337-57.

Freedman, Craig. Why Did Japan Stumble? Cheltenham, UK: Edward Elgar, 1999.

Freedman, Craig. Economic Reform in Japan. Cheltenham, UK: Edward Elgar, 2001.

Hoshi, Takeo and Hugh Patrick. Crisis and Change in the Japanese Financial System. Boston: Kluwer Academic Publishers, 2000.

Ito, Takatoshi. The Japanese Economy. Cambridge, MA: The MIT Press, 1992.

Kane, Edward. "Accelerated Inflation, Technology Induced Innovation and the Decreasing Effectiveness of Banking Regulation." Journal of Finance. 36 (May 1981): 355-67.

Kawaura, Akihiko and Sumner La Croix. "Institutional Change: Why It Happens, Why It Doesn't." Paper presented at conference Institutional Change in Japan: Why It Happens, Why It Doesn't, January 5-6, 2003, East-West Center, University of Hawaii at Manoa.

Korea Economic Institute. "Political and Economic Reform in South Korea." In Cooperation and Reform on the Korean Peninsula. Washington DC: Korea Economic Institute, 2002.

Krugman, Paul. "The Myth of Asia's Miracle." Foreign Affairs. (November/ December 1994): 62-78.

Krugman, Paul. "It's Baaack: Japan's Slump and the Return of the Liquidity Trap," Brookings Papers on Economic Activity. 2 (1998): 137-87.

Krugman, Paul. The Return of Depression Economics. New York: W. W. Norton, 2002.

Kuwayama, Patricia. "Postal Banking in the United States and Japan: A Comparative Analysis." Bank of Japan Monetary and Economic Studies. 18 (May 2000): 73-104.

Lee, Chung H. "The Government, Financial System, and Large Private Enterprises in the Economic Development of South Korea." World Development. 20 (2: 1992): 187-97.

Lee, Chung H. "The State and Institutions in East Asian Economic Development." Journal of the Korean Economy. 3 (Spring 2002): 1-17.

Lee, Chung H. "Institutional Reform in Japan and Korea: Why the Difference?" Paper presented at conference Institutional Change in Japan: Why It Happens, Why It Doesn't, January 5-6, 2003, East-West Center, University of Hawaii at Manoa.

Lincoln, Edward J. Arthritic Japan: The Slow Pace of Economic Reform. Washington, DC: Brookings Institution Press, 2001.

McCallum, Bennett. “Japanese Monetary Policy, 1991-2001.” Economic Quarterly. Federal Reserve Bank of Richmond. 89 (Winter 2003): 1-31.

Mikitani, Ryoichi and Adam S. Posen. Japan's Financial Crisis and Its Parallels to U.S. Experience. Washington, DC: Institute for International Economics, September 2000.

Noland, Marcus and Adam Posen. "The Scapegoats for Japanese Deflation." Financial Times. December 6, 2002.

O'Hara, Maureen and David Easley. "The Postal Savings System in the Depression.” Journal of Economic History 34 (1979): 741-53.

Okina, Yuri. "Recent Developments Surrounding Japan's Postal Savings Business 
and Its Future Position in the Financial System." Japan Research Quarterly. Autumn 2000.

Ono, Hiroshi and Marcus E. Rebick. "Constraints on the Level and Efficient Use of Labor in Japan." NBER Working Paper 9484. Online. Available at: www.nber.org/papers/w9484. Accessed February 2003.

Patrick, Hugh. "The Japanese Economy: Sustained Recovery and Growth Not Yet Assured." Annual Report 2003-2004, Center on Japanese Economy and Business, Columbia University, October 2004.

Posen, Adam. Restoring Japan's Economic Growth. Washington, DC: Institute for International Economics, 1998.

Schoppa, L. J. "Japan, the Reluctant Reformer," Foreign Affairs. 80 (October/ November 2001): 76-90.

World Bank. The East Asian Miracle, World Bank Policy Research Report. New York: Oxford University Press, 1993. 


\section{Japanese lifetime employment A century's perspective

\author{
Chiaki Moriguchi and Hiroshi Ono
}

\section{Introduction}

Sociologists and economists have long recognized the employment security and corporate loyalty shared by white-collar and blue-collar employees in large firms as a uniquely Japanese institution (Abegglen 1958; Dore 1973; Shirai 1983; Koike 1988). At the same time, many scholars have predicted the demise of so-called Japanese lifetime employment. Cole (1971b) argued that it was not sustainable under high economic growth, as chronic labor shortages would raise employees' outside options and they would then be tempted to move from one job to another. Beck and Beck (1994) and others predicted that the economic slowdown in the 1990s coupled with the globalization of financial markets would change managerial incentives. Infusion of foreign capital and necessity of rationalization, they argued, would promote American-style personnel practices, such as layoffs, performance pay, and mid-career hiring, and undermine the precarious equilibrium between management and labor.

Contrary to the scholarly predictions and journalistic reports, empirical studies have so far detected no major changes in the practice of lifetime employment pertaining to "core" employees. Although quantifying the extent of lifetime employment has been difficult due to the lack of a simple empirical definition, for one measure, the proportion of long-tenure workers (ten years or longer) in Japan averaged 43 percent in the 1990s, while the same proportion in the U.S. was 26 percent (Auer and Cazes 2000). ${ }^{1}$ Following up the study by Hashimoto and Raisian (1985), Kato (2001) shows that ten-year job retention rates of core male employees (age 30 to 44 with more than five years of tenure) changed little from 1977-87 to 1987-97. Tsuru (2002) documents that the ratios of long-term male employees to the total workforce increased in the 1980s and remained stable throughout the 1990s in firms of all sizes. ${ }^{2}$ Labor turnover data confirm these observations. As Figure 6.1 shows, the establishment-level separation rates of manufacturing workers declined considerably during the high-growth period (1960-75) and remained low thereafter, with only a mild upward trend since 1996. Note that the data cover smaller establish- 


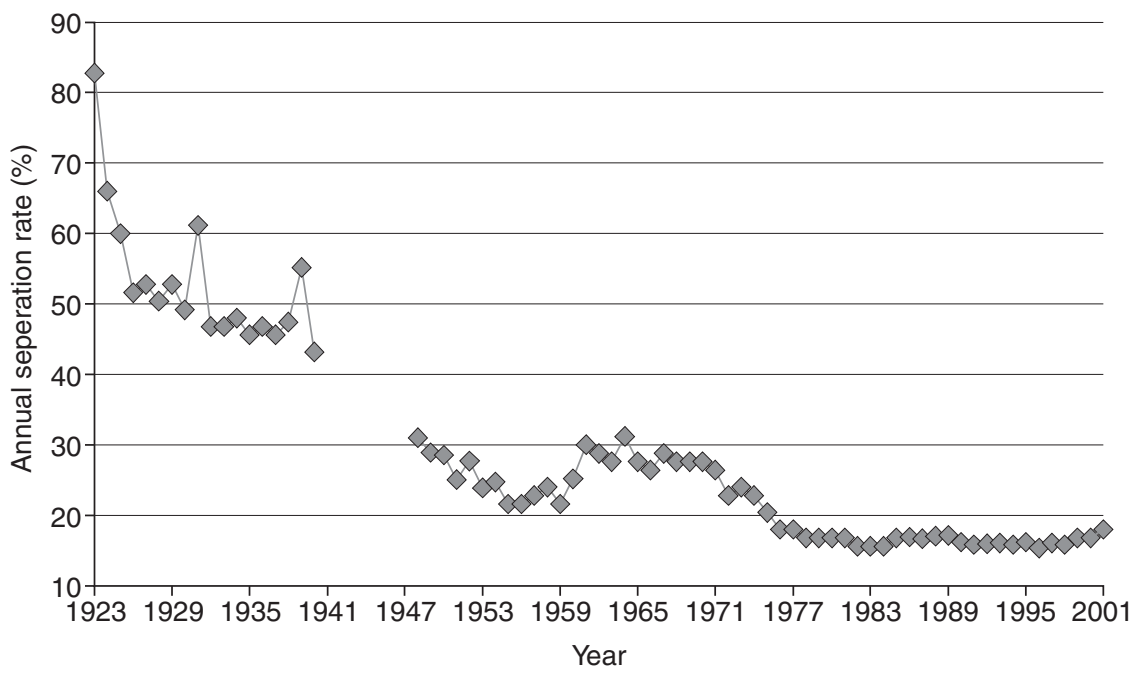

Figure 6.1 Separation rates of manufacturing workers, 1923-2001 ${ }^{3}$ (sources: for 1923-36, Nihon Rodo Undo Shiryo Iinkai (1959); for 1937-40, Ohara Shakai Mondai Kenkyusho (1964); for 1948-2002, Ministry of Labor statistics).

ments (employing 30 or more workers) as well as female employees, for whom lifetime employment has been less prevalent. Moreover, "separations" in the data include intra-firm transfers of employees across establishments, a common employment adjustment method to avoid dismissals.

Why does lifetime employment persist in Japan? Why do we not observe a drastic institutional change despite the more-than-a-decade-long economic stagnation? The first objective of this chapter is to introduce a conceptual framework motivated by personnel economics and sociology to study the stability and persistence of Japanese lifetime employment. In light of recent advances in personnel economics, we characterize today's lifetime employment as a cluster of human resource management (HRM) practices that constitute a self-enforcing equilibrium. We also examine these practices within the context of the Japanese economic system in which firm-level practices interact with macro-level legal, political, and social institutions. The second objective of this chapter is to apply this framework to a historical analysis and investigate the formation and transformation of lifetime employment over the last several decades.

What can history tell us? Our analysis delivers two main messages. First, Japanese lifetime employment is a product of dynamic interactions among management, labor, and government in response to changing environments. As such, the practice evolved into a set of sophisticated and interdependent HRM practices. Second, the firm-level practices were 


\section{Chiaki Moriguchi and Hiroshi Ono}

reinforced by the endogenous formation of macro-level institutions, such as labor laws, state welfare policies, and social norms. As a consequence, today's lifetime employment is deeply embedded into complementary practices and institutions, resulting in its resilience and stability.

The rest of the chapter is structured as follows. The following section lays out a conceptual framework. Pages 155-67 present a historical analysis, documenting the evolution of Japanese lifetime employment. On pages $167-9$ we speculate about the future course of lifetime employment, and the final section presents our conclusion.

\section{Re-conceptualizing lifetime employment}

Recent literature in personnel economics has highlighted a potential complementarity among HRM practices. ${ }^{4}$ HRM practices are complementary to one another if the marginal returns from using one practice increase with the usage of another practice. Since the early 1980s, a number of American manufacturing firms have introduced aspects of Japanese-style HRM practices, such as small group activities and flexible job assignments, to improve labor productivity. In many instances, their experiments failed (Brown and Reich 1989; Osterman 1994). These and other observations stimulated the theoretical literature that underscores the importance of adopting a set of HRM practices at once as opposed to a piecemeal introduction of a few (e.g. Kandel and Lazear 1992; Kanemoto and MacLeod 1992; Baker et al. 1994; Milgrom and Roberts 1995). Although empirical identification of complementarities had been difficult, using micro survey data a growing number of studies find evidence in support of the theory (e.g. MacDuffie 1995; Ichniowski et al. 1997; Kato and Morishima 2002). In light of these advances, we re-conceptualize lifetime employment as a cluster of complementary HRM practices.

Lifetime employment commonly refers to long-term employment contracts (i.e. indefinite contracts specifying no fixed duration) with an implicit handshake between employers and regular employees. Since Japan's statutory laws stipulate that either party can terminate such contracts at any time with a short advance notice, the contracts have to be internally enforced, that is, there must be an incentive for both management and workers to conform to their promise. ${ }^{5}$ Observe, however, that long-term employment is intrinsically fragile as any changes in product or labor market conditions would affect the ex post incentive of one of the two parties. For example, during economic prosperity workers have a greater incentive to leave their firms, while during recessions employers have a stronger incentive to renege on their promises. So what makes long-term employment contracts self-enforcing?

In practice, the following areas in HRM are found critical in supporting lifetime employment in Japanese firms (Koike 1988; Shimada 1988; Sako and Sato 1997; Kato 2000; Tachibanaki and Noda 2000): (1) human capital 
development that raises an employee's productivity over his tenure and provides managerial incentives to retain the employee, e.g. corporate training, job rotations, small group activities such as quality circles; (2) a compensation system that provides incentives for employees to exert effort, acquire desirable human capital, and remain with the firm, e.g. seniorityplus-merit wage, internal promotion, bonuses, corporate pensions; (3) employment adjustment methods that protect the level of employment, while providing management with alternative ways to reduce labor costs during business downturns, e.g. hiring freeze, intra- and inter-firm transfers, voluntary retirement; and (4) internal enforcement and coordination mechanisms that facilitate information sharing, enable employees to monitor management, and encourage labor-management cooperation, e.g. enterprise unions, joint labor-management committees, workplace socialization. In short, today's lifetime employment consists of a set of sophisticated and interdependent HRM practices that encompasses multiple aspects of work organization and labor-management relations.

In our framework, micro-level HRM practices are embedded within the broader context of an employment system of the Japanese economy (Aoki 1990; Moriguchi 2000). Following Coleman (1990), we conceptualize lifetime employment as an outcome of the long-run interactions between micro- and macro-level institutions. At the macro level, the government designs labor market regulations, union laws, and social welfare policies that impact incentives of labor and management. ${ }^{6}$ Although these macrolevel institutions are exogenous to individual employers and workers, in the long run they are endogenously shaped as they interact with microlevel institutions. For example, dominant HRM practices influence government policies as they create or eliminate demand for particular laws or regulations. Similarly, we claim that social norms - notably loyalty, trust, and commitment, often assumed to be fixed cultural traits - evolve endogenously as they are nurtured by micro-level economic and social exchange relations. In general, the long-run interactions between management, labor, and the government give rise to a stable employment system, in which micro-level institutions and macro-level institutions are complementary to one another.

In the following historical analysis, we focus on major historical events - the Great Depression, the postwar occupational reforms, the highgrowth period, the Oil Shock, and the post-bubble stagnation - and document how they shaped and transformed lifetime employment in Japan.

\section{The creation and transformation of lifetime employment}

\section{Corporate welfarism and the challenge of the Great Depression}

Lifetime employment traced its origins to corporate welfarism that emerged during the interwar period (Hyodo 1971; Hazama 1978; Gordon 


\section{Chiaki Moriguchi and Hiroshi Ono}

1985; Moriguchi 2000). World War I brought about a rapid growth of heavy industries and a shortage of skilled labor. Moreover, as mechanization advanced and firms grew larger, production technology and work organization became increasingly firm-specific. To train and retain skilled workers (jukuren-ko), who were well-known for being footloose and lacking corporate loyalty, major employers began introducing a variety of HRM practices (Kyochokai 1924).

In particular, leading firms set up corporate apprenticeship schools rather than relying on public vocational schools, and gradually reduced mid-career hiring in favor of workers trained in-house. Initially, however, a majority of apprentices left their employers after, if not during, a training period for better wage offers (Hyodo 1971, 407; Hazama 1978, 513). To reduce labor turnover, which often exceeded an annual rate of 80 percent during the 1910s, employers introduced for blue-collar workers pecuniary incentives, such as service bonuses, periodic pay raises, and retirement allowances, which were previously offered only to white-collar employees. Management awarded pay raises to a fixed percentage of workers based on their merit and length of service, and instituted retirement allowances whose amount increased with the years of service. Compared to the postwar practices, however, the amount and coverage of these benefits were small and their payments irregular (Showa Dojinkai 1960, 265-80).

In response to the surge of the labor movement in the late 1910s, leading employers also introduced plant-level employee representation or "factory councils" to facilitate labor-management communication and preempt employee discontent (Kyochokai 1926). Unlike enterprise unions in the postwar period, these councils consisted exclusively of blue-collar employees, reflecting a sharp status distinction between blue-collar and white-collar employees within an establishment during the prewar period. Moreover, in most cases, management restricted the subjects of council meetings to issues such as health, safety, recreation, and efficiency improvements, refusing to discuss wages, hours, and benefits.

Early corporate welfarism was confined to a minority of prosperous employers in the economy - such as Mitsubishi Shipyards, Sumitomo Metals, Hitachi Engineering, Nippon Electric, and Yahata Ironworks consisting of no more than a few hundred large private and state-owned establishments mostly in capital-intensive industries. The number of establishments instituting factory councils, for example, was fewer than 200 throughout the 1920s (Kyochokai 1929, ch. 9). Although the HRM practices became less erratic and more systematized among these establishments during the interwar period, employers retained full discretion over qualifying or disqualifying individual employees as well as modifying or discontinuing the practices at will with legal impunity. In the words of a contemporary government official, the vaunted corporate welfarism rested entirely on "the whims of capitalists" (Garon 1988, 172).

The Japanese economy was troubled by successive downturns in the 
interwar period, including the 1921 post-World War I recession, the 1923 Kanto Great Earthquake, and the 1926 Financial Crisis. The largest shock was the Great Depression of 1929-31, during which time the nation's industrial production declined by 8 percent. Numerous firms, including the largest employers, reduced wages, cancelled benefits, and undertook largescale layoffs. The level of employment fell by more than 8 percent in 1929-31. In protest, workers organized strikes and public demonstrations. In 1930 alone, more than 800 disputes broke out involving 72,000 workers, and over one million working days were lost (see Figure 6.2). The surge of labor disputes prompted the government to exhort business leaders not to dismiss workers en masse for fear of widespread unemployment and social disorder. Workers' protest and government pressure urged management to develop measures to avoid dismissals. Two major methods of employment adjustment, which became common practices after World War II, emerged during the interwar period.

First, when dismissals became inevitable, major employers solicited workers to accept voluntary retirement (kibo taishoku) in exchange for an augmented retirement allowance. Although voluntary retirement was de facto dismissal, management consulted employees in advance and the sum of retirement allowance received by the employees, which increased with their length of tenure, was substantial (Shakaikyoku 1936). ${ }^{7}$ The practice of voluntary retirement was often effective in moderating workers' discontent

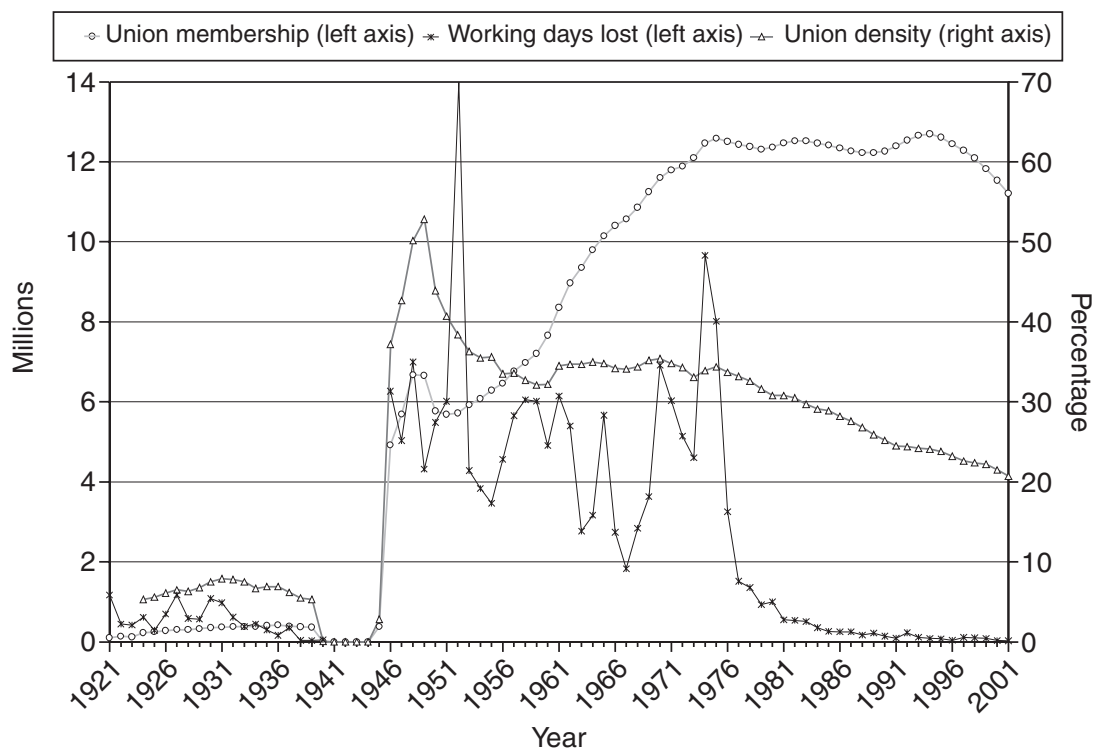

Figure 6.2 Union membership, density, and working days lost, 1921-20018 (sources: for 1921-46, Nihon Rodo Shiryo Iinkai (1959); for 1947-2001, Ministry of Labor Statistics). 


\section{Chiaki Moriguchi and Hiroshi Ono}

and helped maintain cooperative relations between management and remaining employees (Gordon 1985, 201; Nishinarita 1988, 183-92).

Second, large firms began to use temporary workers (rinji-ko) as a buffer to insulate core employees from business fluctuations. Previously, temporary workers were commonly promoted to regular worker status after a short probationary period. During the interwar period, however, the status of temporary workers became fixed indefinitely. They were hired under short-term renewable contracts and let go first when business conditions deteriorated. As management disqualified temporary workers from retirement allowance plans, the cost of dismissing them was significantly lower than dismissing regular workers (Hyodo 1971, 430; Hazama 1978, 498).

To summarize, during the interwar period, leading employers introduced a set of HRM practices, such as company training, incentive pay, plant-level employee representation, and employment security, to foster core skilled workers. Workers' protest against employment reduction and the elimination of benefits, together with government intermediation during labor disputes, gradually established an expectation that these benefits were part of the "just reward" that could not be withdrawn at management's will (Gordon 1985, 196-206). In response, management developed methods of adjusting employment to mitigate the cost of longterm commitment in business downturns. As Figure 6.1 shows, separation rates of production workers declined from over 60 percent in the early 1920 s to below 50 percent in the late 1930s, part of which may be attributed to the spread of corporate welfarism. Although a vast majority of workers in the economy remained highly mobile, a set of stable and loyal workers began to emerge in leading firms.

Reflecting the development in firm-level HRM practices, complementary labor laws began to take shape during the 1930s (Moriguchi 2003). First, prompted by rising unemployment, the government proposed a national unemployment insurance bill in 1932. In the legislative process, however, the bill was transformed into law that incorporated an aspect of unemployment insurance into corporate welfare practices. The law mandated every employer (with 30 or more workers) to establish a retirement allowance fund for an employee and pay an allowance in case of separation. Affirming prevailing HRM practices, the law permitted employers to vary an amount of the allowance depending on an employee's length of service and the reason for separation. After the enactment of the law in 1936, retirement allowance plans diffused to smaller-sized establishments in the economy.

Second, despite repeated legislative attempts by progressive politicians and government officials, trade union law never materialized in the prewar period. Business leaders strongly opposed union legislation throughout the period, claiming that factory councils provided employees with a form of employee representation that was more conducive to "labor-capital cooperation (roshi kyocho)" than trade unions. Although factory councils did not give an independent voice to workers, evidence indicates that 
organized labor failed to gain workers' support in large firms that instituted corporate welfarism. The absence of legal protection notwithstanding, trade unions organized more than 900 establishments and 400,000 workers by the mid-1930s. All major firms, however, remained nonunion. Trade unions were dissolved by the military government after the Japanese invasion of China in $1937 .{ }^{9}$

\section{Postwar occupational reforms and the turbulent years}

Immediately after Japan's surrender in 1945, the nation was placed under the indirect governance of the Supreme Commander for the Allied Powers (SCAP). Even before the enactment of the Trade Union Law, which recognized workers' right to bargain collectively for the first time, there was an explosion of the labor movement led by Japanese workers under the slogan of "democratization of management." Union density (the percentage of union membership in the total labor force) rose to 41 percent by 1946, compared to the prewar peak of 8 percent (see Figure 6.2). In many cases, workers spontaneously formed what they called "employee unions" (jugyoin kumiai) that consisted of white-collar and blue-collar employees within an establishment or a company. In contrast to prewar industrial relations, newly established unions forcefully demanded the equal treatment of all employees, a contractual employment guarantee, and direct participation in management in order to improve their status, welfare, and bargaining power. The labor movement quickly radicalized under the leadership of the Congress of Industrial Unions, often resorting to collective violence against managers during labor disputes.

While management was paralyzed by economic disorder and political turmoil, many employee unions won extremely favorable contracts during 1945-49 that stipulated generous wage increases, a variety of welfare benefits, and employment security (Gordon 1985, 345). By 1950, a substantial majority of large firms (with 500 or more employees) had instituted major corporate welfare programs (see Table 6.1). Many unions also won a "union shop" provision that required every regular employee of a company to be a union member, and in exchange management won a clause requiring every union member to be an employee of the company. This exclusive employee membership later became a hallmark of enterprise unionism. As a dramatic symbol of labor victory, major unions also won pure "seniority wages" in which wages were determined based on employees' age, tenure, and family conditions, rejecting any merit-based components insisted upon by employers. ${ }^{10}$ Labor's initial victory, however, was soon challenged by management's counteroffensive.

In 1949, the SCAP implemented a drastic deflationary policy to bring the Japanese economy under free market mechanisms, plunging it into a sharp recession. As generous government subsidies suddenly disappeared, many companies faced a choice between drastic rationalization and 
Table 6.1 Corporate welfare programs in 1949

\begin{tabular}{llllc}
\hline Welfare program & All firms & $\begin{array}{l}\text { 500 or more } \\
\text { workers }\end{array}$ & $\begin{array}{l}\text { 100-499 } \\
\text { workers }\end{array}$ & $\begin{array}{l}\text { 30-99 } \\
\text { workers }\end{array}$ \\
\hline Company housing & 58.7 & 96.3 & 82.4 & 54.8 \\
Dining facilities & 21.5 & 72.2 & 37.6 & 14.7 \\
Company loan & 9.4 & 31.9 & 14.6 & 6.8 \\
Medical clinic & 18.4 & 96.6 & 43.5 & 7.6 \\
Health and safety & 50.1 & 94.6 & 75.4 & 41.0 \\
Recreation programs & 26.4 & 77.4 & 50.4 & 17.3 \\
Athletic facilities & 22.0 & 87.7 & 46.9 & 11.8 \\
\hline
\end{tabular}

Source: Ministry of Labor $(1969,1540)$.

Note

Percentage of firms adopting each program is reported.

bankruptcy. The 1949-50 recession thus posed a serious challenge to longterm employment. Unions fiercely opposed rationalization plans, demanding complete withdrawal of proposed mass dismissals (Gordon 1985, 388-90). A sense of mutual mistrust between labor and management grew. The most violent labor disputes in Japanese history took place between 1949 and 1954, involving major companies, such as Toshiba, Hitachi, Toyota, and Nissan. As Figure 6.2 shows, the working days lost in 1952 reached an unprecedented 15 million and involved 1.6 million workers.

In almost all major strikes, management eventually prevailed (Yamamoto 1991). During prolonged disputes, radical union leaders typically lost support from core employees of the company, who instead formed or joined the "second union" (daini kumiai). Management concluded an agreement with the second union, expelled the radical leaders, and undertook dismissals by a familiar method of voluntary retirement and augmented dismissal compensation. During the process, unions learned a hard lesson that their unrestrained demands might be unsustainable in the face of economic reality. Employers also learned that rationalization measures could provoke costly labor disputes. The second unions became the foundation for enterprise unionism, characterized by labor-management cooperation in pursuit of corporate goals, that took root in most large Japanese firms in the following decade (Shirai 1992).

Contrary to popular belief, there was no statutory law that guaranteed lifetime employment in Japan. The Japanese Civil Code stipulated that, under an employment contract with no fixed duration, either party can terminate the contract at any time with a two-week advance notice (Article 627[1]). The Labor Standard Law of 1947 obligated employers to pay the equivalent of thirty days' wages when dismissing an employee (Article 20). Except for those restrictions, the legal codes supported the employers' right to dismiss employees. As Table 6.2 documents, by the early 1960s, 
Table 6.2 Employment adjustments during business downturns in 1954-55 and 1962-63

\begin{tabular}{lcc}
\hline Method of employment adjustment & 1954-55 & 1962-63 \\
\hline Reduction of working hours & 48 & 51 \\
Relocation of regular workers & 25 & 31 \\
No contract renewals of temporary workers & 19 & 13 \\
Reduction of outside workers & 3 & 14 \\
No hiring of new workers & 10 & 23 \\
Dismissal or voluntary retirement of regular workers & 17 & 8 \\
\hline
\end{tabular}

Source: Tsuda $(1968,174)$.

Notes

Percentage of firms using each method is reported. One firm may use more than one method. The survey covered firms with 30 or more regular workers in mining, manufacturing and transportation.

however, it was common for Japanese employers to circumvent dismissals by using other means, such as a reduction of working hours, relocation of regular employees, separation of non-regular employees, and the suspension of hiring new workers. In the absence of statutory laws, what compelled management to protect the employment of their workers in the face of declining sales and profits? The role of enterprise unions and the formation of case law provide key answers to this question.

In exchange for their cooperation with management in rationalization and productivity improvements, enterprise unions demanded employment security for their members, i.e. all regular employees, as their first priority. No explicit contractual guarantee of employment security, however, was found in union contracts. Instead the contracts established a clause that required the employer's prior consultation with a union in employment adjustment, among other personnel issues. Importantly, joint labormanagement committees (roshi keiei kyogikai), which were widely introduced during the 1950s and 1960s, played a critical role in facilitating information sharing and joint consultation and establishing mutual trust between labor and management. During business downturns, unions monitored managerial behavior and cooperated in transferring employees and soliciting early retirement. Enterprise unionism thus became a central internal enforcement mechanism for the emerging lifetime employment practice in large firms.

In a parallel development, starting in 1948 the Japanese courts began to rule increasingly in favor of employees in cases of dismissal (Sugeno 1992, 395-412; Tackney 1995, 420-7). Over the next three decades, the accumulation of judicial decisions gradually restricted the employer's right to dismiss employees at will. ${ }^{11}$ In particular, when the dismissals due to business conditions became a major issue during the Oil Crisis in the 1970s, judicial decisions established minimum criteria that employers had to 


\section{Chiaki Moriguchi and Hiroshi Ono}

satisfy before resorting to dismissals, citing the "accepted idea of lifetime employment" and "existing ways of employment adjustment" (Sugeno 1992, 408). ${ }^{12}$ In other words, the interpretations of the law evolved endogenously to incorporate prevailing HRM practices and social expectations. In turn, the accumulation of case law precedents reinforced the HRM practices and transformed expectations into social norms. Since the late 1970s, the courts thus provided legal enforcement for lifetime employment to a certain degree, extending the practice to nonunion employers and smaller firms in the economy.

\section{The high-growth period}

The 1960s and the first half of the 1970s are known as the "high-growth period." The period kickstarted from the "Income Doubling Plan" launched by the Ikeda cabinet in 1960, under which economic goals were set to more than double Japan's GNP in the course of the next decade. Actual results exceeded this, as it took less than seven years to double personal incomes. The real GDP growth rate during 1960-73 averaged 10 percent, and this unprecedented achievement propelled Japan into the ranks of industrially advanced countries.

Corporate profits soared under continuous periods of double-digit growth. Rapid business expansion depleted the supply of labor available in urban centers, and large corporations aggressively recruited workers from rural areas. These companies constructed dormitories and various housing facilities to accommodate the influx of the new workforce. Their employees began to develop the mentality that their jobs would be secure and their earnings would automatically increase with length of service. These expectations were fulfilled. The main managerial concern was recruiting and preserving the workforce. Dismissal became a remote concept. The practice flourished among large firms in the 1960s, and among smaller establishments in the 1970s. Accordingly, separation rates of manufacturing workers declined considerably (see Figure 6.1).

Lifetime employment came to fruition under the favorable economic conditions of the high-growth period (Shimada 1994). Sustained periods of economic growth allowed companies to project longer time horizons as economic conditions became more predictable. For employers, stable employment relationships enhanced the concept of investments in human capital, i.e. the recognition that workers are an important asset, or an investment with real returns.

Companies started to provide considerable education and training to their workers, and developed sophisticated human resource management systems for evaluation, promotion, and compensation. For example, Koike (1997) documents how on-the-job training (OJT) became common practice among manufacturing firms in the late 1950s and 1960s. A long-term perspective shared by both labor and management was crucial for on-the- 
job training to be successful, because skill formation is interrupted if the workers move. The bonus payment system, which covered white-collar and blue-collar employees in all job categories, also spread during the same period, primarily as an instrument to adjust wage levels in response to labor market and firm-specific conditions (Ohashi 1989). ${ }^{13}$

Labor-management relations also stabilized during the high-growth period as firms started to realize the gains from the human capital investment. The annual private sector pay negotiations known as the Spring Offensive (Shunto) was introduced in 1955. The Spring Offensive suffered from low membership, and thus little bargaining power over management in its initial stages. However, sizable wage increases determined by the negotiations during the high-growth period led to larger membership, with respect to both the number of firms and the number of workers. ${ }^{14}$ An important outcome of the Spring Offensive was the standardization of wage increase demands and settlements. In a remarkable display of consensus building, member companies exchanged information to minimize wage dispersion, believing that harmonious labor relations were beneficial for labor and management. Differences in wage increase settlements across firms and industries were common in the formative years of the Spring Offensive, but "virtually disappeared" during the mature period in the mid-1960s (Koshiro 2000). ${ }^{15}$

As expectations of employment security became reality, long-term employment became the norm governing employment relationships in subsequent periods. Regular workers in large firms were increasingly attracted to the economic benefits of the renewed system - mainly "automatic" wage growth - which enabled them to smooth out their consumption and savings over a longer time horizon. ${ }^{16}$ They also enjoyed social benefits such as the status accorded to joining prestigious corporations. Vogel's (1963) reference to Japan's "new middle class" points precisely at this time period when the job of the salaryman characterized by security and prestige became a desirable status among the majority of Japanese.

Lifetime employment, however, also incurred social costs. Sanctions for deviating from the norm were met with certain penalties. The stigma attached to those who changed jobs a number of times hampered their chances of reemployment and resulted in lower wages. ${ }^{17}$ Leaving a job signaled a "lack of sincerity" much like a divorce (Dore 1983). As commitment to the employer became customary, workers became reluctant to accept as social equals those individuals hired with prior job experience (Cole 1971b). Large companies respected the implicit agreement and their employees were seldom dismissed: "when dismissal did occur it was an industrial death sentence with consequences far more severe than they would be in many other industrial societies" (Crawcour 1978, p. 240). Social pressures to conform to the norm thus functioned as a powerful enforcement mechanism for long-term employment. 


\section{Chiaki Moriguchi and Hiroshi Ono}

\section{The oil crisis}

The stability of the employment relationship was seriously challenged with the First Oil Shock in 1973, followed by the Second Oil Shock in 1979. Real GNP growth averaged 4.7 percent between 1975 and 1980, and 3.7 percent between 1980 and 1985. Employers initially responded to the shock by upholding their renewed commitment to employment stability. Much like the methods used to adjust employment levels during the Occupation period (see Table 6.2), dismissal was the last resort. Instead, large and medium-sized firms made concerted efforts to reduce overtime, transfer workers within the firm, reduce new recruits, sell corporate assets, cut executive bonuses and salaries, and cut dividends (Shimada 1979) ${ }^{18}$ In spite of these efforts, the shocks proved to be overburdening even for largest firms, forcing them ultimately to adjust their regular workforce mainly in the form of voluntary retirement and permanent transfers. During December 1973 and February 1978, more than one million regular employees lost their jobs (Koshiro 1983). ${ }^{19}$

In response, there was an initial surge of labor disputes in 1974-75 involving more than 5.3 million workers (see Figure 6.2). Several cases of dismissals were brought before the court, leading to the judiciary decisions that restricted the right of dismissals due to business conditions, as discussed earlier. Most enterprise unions, however, eventually approved employment adjustment plans and cooperated with management to carry them out. Prior consultations at joint labor-management committees were particularly useful in facilitating labor-management cooperation during the crisis. Furthermore, in 1975 the labor movement adopted a voluntary wage restraint policy intended to promote macroeconomic stability (Takanashi 2002). In a move that reflected the high priority accorded to employment security, organized labor accepted a substantial reduction in real wages in the Spring Offensive of 1980 immediately following the Second Oil Shock (Shimada 1992).

It is against this backdrop that the government launched the Employment Stability Project in 1977. The Ministry of Labor and the Ministry of Trade and Industry were both determined to preserve employment security because they and the business community believed it was the key to industrial and social harmony (Cole 1979). The objectives of the Project were twofold. The first aim was to stabilize employment by transferring workers from declining industries to new, more profitable lines of business. Employers who were forced to temporarily lay off workers due to business fluctuations were offered rebates to transfer workers, often into newly established affiliates. ${ }^{20}$ Second, the Project provided incentives for employers to keep their workers employed, by subsidizing the costs involved with re-training workers in the skills necessary for new lines of business. Subsidies were also provided in circumstances where employers wished to implement short-time schedules, including those who were 
working zero hours or temporarily staying at home (Genda and Rebick 2000). Hashimoto (1993) finds that the government-led employment stabilization movement reduced employment sensitivity to the business cycle, i.e. firms responded to business fluctuations mainly through adjustment of work hours rather than employment.

It is often argued that Japan survived the oil crisis much better than their Western counterparts. Such views should not overlook the considerable measures undertaken by government, management, and labor to minimize the extent of the external shocks triggered by the crisis. As Shimada (1992) argues, the priority on employment stability established during the 1970s formed a backbone of the Japanese employment system in subsequent decades.

\section{The bubble economy and its aftermath}

The conclusion of the Plaza Accords in September 1985 triggered a sharp appreciation of the yen relative to the dollar. During the next ten months, the value of the yen jumped from 240 to 150 yen per dollar. The enormous price disadvantage of Japanese imports consequently led to a decline in product demand, and lifetime employment was once again tested as employers faced pressures to let workers go. However, the downturn was short-lived; the economy bottomed out by the end of 1986 and managed a quick recovery. The low-interest-rate policy intended to stabilize macroeconomic performance soon led to aggressive corporate investments. Asset inflation, mainly through the appreciation of land and stock prices, encouraged further investments. This upward spiral led to the so-called bubble economy (Noguchi 1994).

The wealth effect stimulated consumer demand, and corporations responded by expanding their productive capacity. Employers hoarded labor at unprecedented levels. In previous episodes of expansion, employers exercised caution in hiring and recruiting, and adjusted to upward swings through overtime work. However, corporate confidence was high and the forecast so positive during the bubble years that corporations recruited as much labor as possible. The result was a complete turnaround, from a buyer's market to a seller's market. Labor shortage problems became pervasive, especially among large firms which continued to hoard workers at an aggressive rate. The demand for college graduates was greater because firms desired a higher quality labor force, and because they were able to pay higher salaries. In the peak year of 1991, large firms with more than 1,000 employees hired 145,600 new college graduates, or 64.7 percent of the total supply of college graduates, which represented a 60 percent increase compared to the mid-1980s (Ariga et al. 2000).

The prolonged period of asset inflation showed initial signs of collapse in 1991. By October, stock prices had fallen 50 percent from their 1989 peak. In December, the Economic Planning Agency acknowledged that 


\section{Chiaki Moriguchi and Hiroshi Ono}

the economy had entered a slump. To deal with the recession, employers once again resorted to the conventional methods of adjustment, by reducing overtime work, reducing new hiring, transferring workers to subsidiaries, and encouraging early or voluntary retirement. Employee dismissal remained the last resort, but became inevitable. Chuma (1994) claims that reductions in the core workforce started as early as the spring of 1993.

The aftermath of the bubble economy dragged on as firms were confronted with not only a mountain of bad loans, but a mass of surplus labor. Despite increasing pressures to let workers go, management continued to uphold the lifetime employment practice throughout the 1990s (Genda and Rebick 2000; Kato 2001; Rebick 2001). Job retention rates and employment durations remained virtually unchanged in comparison to the 1980s. Management kept core workers employed by resorting to transfers, whether they be intra-firm or to subsidiaries within a corporate group (Sako and Sato 1997; Kato 2001). Enterprise unions mainly negotiated wage increases that were in line with productivity gains, and their willingness to accept virtually no wage growth kept unemployment rates low in the 1990s (Genda and Rebick 2000). No major outbreaks of labor disputes have been observed since the mid-1970s (see Figure 6.2). On the other hand, repeated concessions signaled the union's lack of bargaining power, leading many workers to see their unions as "powerless" (Kawakita 1997).

Two forms of government intervention in the 1990s also contributed to the maintenance of employment security. First, a new system was established in 1997 to provide special subsidies for job creation and skill formation in fifteen new growth areas, such as information technology and social welfare. Second, the government paid employers direct subsidies to retain or employ older workers (Genda and Rebick 2000). The system of deferred compensation implies that employees closer to a firm's mandatory retirement age are paid more than their marginal product, which makes them more vulnerable to dismissals than younger workers. Government subsidies were therefore targeted specifically to protect older workers during the economic downturn.

The piecemeal adjustment to protect older workers had the undesirable consequence of depressing youth labor market conditions. Kato (2001) finds that employment remained stable for core workers in the 1990s, as reviewed previously, but less so for younger workers and middle-aged workers with short tenure. The primary cause of the problem was that employers, faced with the post-bubble surplus of labor, dramatically reduced their intakes of new hires (Rebick 1998). Furthermore, labor hoarding during the bubble years left a diamond-shaped age composition of the workforce, with an overstock of workers in their thirties. This imbalanced age composition misaligned the system of internal promotion. Eventually, the bulk of the bubble-cohort must be promoted, or it will demoralize subsequent cohorts. However, management faces a dilemma 
because the average quality of the bubble-cohort is likely to be lower than that of the subsequent cohorts due to the lower recruiting standards used during the period (Ariga et al. 2000). The lack of organizational restructuring has therefore worsened the labor market conditions for younger employees. Their promotion rates have slowed down, and their training opportunities within firms have been depressed (Genda 2000).

\section{The future of the lifetime employment system}

In the midst of the longest economic stagnation in the nation's history, doubts about the future of lifetime employment have surfaced once again and continue to captivate the public's attention. A February 2002 survey by Nikkei Research reported that over half of 800 firms surveyed "could no longer sustain" permanent employment practices. ${ }^{21}$ In the business community, Matsushita's announcement of 8,000 job cuts through voluntary layoffs during fiscal year 2002 was received as a turning point in Japanese industrial relations. ${ }^{22}$ Matsushita, in both its organization and history, represents a microcosm of the Japanese firm, often credited as the first to effectively implement lifetime employment. Its announcement was an impetus for change, as it triggered an avalanche of corporate downsizing plans among other Japanese companies. As of November 2001, 82 firms had announced plans to discharge a total of 120,000 workers by fiscal year $2004 .^{23}$ Is this the end of Japanese lifetime employment? Or will the practice maintain its resilience and resurge once economic conditions recover?

There is some evidence suggesting that employment adjustments in the 2000s may be tougher than in the previous decades. Conventional measures of employment adjustment are becoming more difficult to implement. Reassigning or transferring workers to other parts of the business may no longer be a viable solution. Smaller firms that serve on the receiving end of surplus workers from large companies are getting saturated with workers; moreover, they face hardship themselves, and can no longer absorb such "redundancies from above" (Ono 2002). Early or voluntary retirement risks adverse selection, i.e. management may lose high-ability workers instead of the targeted low-ability workers. Further, early retirement is likely a bad deal for the average worker. Studies have shown that, in many cases, the lump-sum compensation offered through these plans would not compensate for the loss in earnings when viewed over a lifetime (Ichinose 2001).

Despite increasing pressures to reduce redundant labor, recent survey results confirm that dismissal of regular employees continues to be the last resort among Japanese firms (see Table 6.3). The Japan Institute of Labor (2001b) reports that preferences for employment adjustments among Japanese employers have changed little. Maintaining a reserve of excess labor under economic duress, however, is not without its costs. Ono and Rebick (2003) estimate that the quantity of surplus labor retained among 
168 Chiaki Moriguchi and Hiroshi Ono

Table 6.3 Methods of employment adjustment in 2000

\begin{tabular}{lr}
\hline Adjustment method & $\%$ \\
\hline Restricting overtime work & 11 \\
Reassigning workers to other parts of the business & 7 \\
Temporary transfer (shukko) & 5 \\
Reducing (or stopping) mid-year intakes of new employees & 4 \\
Increasing holiday leave and days-off & 2 \\
Dismissing part-time and temporary workers & 2 \\
Dismissing or calling for the voluntary retirement of regular employees & 2 \\
\hline
\end{tabular}

Source: Ministry of Health, Labor and Welfare (2001).

Japanese employers is around 5 percent of total employment, or about the same as the unemployment rate in 2002. The impact of this efficiency loss on labor productivity is certainly not negligible. Further, as discussed previously, the burden of protecting the core workforce falls disproportionately on younger workers. In March 2002, the unemployment rate among workers between the ages of 15 and 29 recorded 9.6 percent, in comparison to the nation's average of 5.2 percent.

One obvious prescription is a more flexible labor market. But the Japanese labor market that matured under the premise of lifetime employment has yet to develop an infrastructure that facilitates an efficient reallocation of workers across corporate boundaries. Table 6.4 shows the top five reasons why workers do not, or cannot, change jobs. The reasons accentuate the sentiments of many Japanese workers who feel "stuck" with their current employers. The internal labor markets that presume entry from below impede the mobility of workers who are separated from their firms in mid-career (Recruit Works Institute 2001; Ono and Rebick 2003). Older workers are more likely to be endowed with higher levels of firm-specific skills, and by definition this makes it more difficult to transfer their skills to other firms. The seniority-plus-merit pay makes it even harder for workers to leave their employers because it likely results in wage loss. Hence, mid-career workers have little choice but to remain with their current employers; they don't want to quit their firms and other firms don't want to hire them.

A notable example of employers' aversion to older workers is found in job postings, where employers explicitly impose age restrictions on their new hires. In 1999, over 90 percent of Japanese firms were found to impose age limits - generally 35 to 40 - on their job openings (Japan Institute of Labor 2001c). This so-called "age limit" problem continues to be the most common reason for workers not changing jobs in the Japanese labor market (see Table 6.4). Under pressure to reform, the government introduced guidelines to abolish age limits in recruiting and hiring in October 2001 as part of the revised Employment Measures Law. However, 
Table 6.4 Top five reasons why workers didn’t change jobs in 2001

\begin{tabular}{lc}
\hline Reason & $\%$ \\
\hline I exceed the age limit of the job postings & 40.8 \\
My work experience is not transferable to general society & 23.4 \\
Returns to seniority will be lost and I will suffer wage loss & 21.8 \\
I do not know how to look for a job & 19.1 \\
I will lose personal contacts established through my work & 14.1 \\
\hline
\end{tabular}

Source: Recruit Works Institute (2001).

the guidelines specify ten exceptions where age restrictions are acceptable. One of the exceptions is phrased almost specifically to prevent disruptions in the seniority system. ${ }^{24}$ As it stands, the guidelines are mainly viewed as a cosmetic gesture, and their immediate impact on job mobility remains questionable. In short, a labor market for job changers has not yet developed in Japan, and without it the worker with general human capital will suffer severe penalties from job separations.

Finally, the long-term threat which may undermine not only the employment system but also economic growth itself is Japan's aging population. The rate of aging of the workforce in Japan is the fastest in the world, compounded by longer life expectancy and lower fertility. The implications for the economy are ominous. The aging population will eventually lead to an inverted pyramid-shaped age composition of the workforce and increase the burden for the active labor force to support the private and public pension system. To summarize, the Japanese labor market faces a labor surplus problem in the short run, and a labor shortage problem in the long run. These problems have yet to find solutions.

\section{Conclusion}

This chapter examined the historical process in which Japanese lifetime employment was shaped and became institutionalized over the past century as a result of the dynamic interactions among labor, management, and government. Pioneered by leading firms during the interwar period, the lifetime employment practice matured into a cluster of HRM policies, diffused to a wider set of firms, and became more deeply institutionalized and increasingly socially embedded at each historical event examined in

our chapter. In particular, we documented the endogenous formation of macro-level institutions that reinforced the lifetime employment practice. The development of state welfare policies, enterprise unions, case laws, government subsidies, and the evolution of social norms are primary examples of such institutions. We argued that the practice's remarkable stability and resilience to economic shocks cannot be explained without the existence of these complementary institutions. 


\section{Chiaki Moriguchi and Hiroshi Ono}

What does history tell us about the future of Japanese lifetime employment? So far the system has emerged from each economic shock by consolidating itself more firmly with necessary adjustments and innovations. As long as the complementary institutions continue to support it, lifetime employment will likely persist. But should it change?

According to our analysis, the shift from spot labor markets to long-term employment was initially driven by efficiency considerations. By achieving greater productivity through higher human capital, it produced benefits to both management and labor in the form of higher profit and greater employment security. The government endorsed the corporate practices as it brought about economic development and industrial peace at a relatively low social welfare cost to the state. However, the efficiency of lifetime employment is by no means guaranteed: it depends on several key parameters, most importantly the growth rate of the firm, the nature of human capital, and labor market conditions. In particular, during the high-growth period and again in the bubble economy, under the economic conditions favorable to management, the lifetime employment practice was extended to a much wider segment of the economy with perhaps little gain in long-run economic efficiency. Once extended, labor's oppositions, government regulatory support, and court decisions made it difficult to reverse the practice. Even for elite corporations, core proponents and the traditional mainstay of lifetime employment, the increasing importance of professional occupations with general human capital may limit the returns from lifetime employment. In general, in evaluating the future economic implications of the system, one must discern long-run trends in the key parameters.

Furthermore, several decades after its inception, lifetime employment has become deeply embedded in Japanese society, inseparably integrated into political, legal, and social institutions. As such, the continuation of the system is no longer dictated by its firm-level efficiency concerns. For example, as employment security became a norm and a fundamental premise upon which the society is built, the social benefits of employment security are far greater than its direct economic benefits. The system, however, also created social costs that were originally unforeseen. For instance, lifetime employment produced a stark status difference between regular and non-regular workers, promoted occupational segregation by gender between career and non-career jobs, and brought about high unemployment for the young and the old during recessions. In other words, it is important also to evaluate the social implications of lifetime employment, which go far beyond the original efficiency implications.

To give careful assessment to the social and economic implications of Japanese lifetime employment is beyond the scope of this chapter. By providing a historical perspective, however, this chapter underscores the importance of understanding the dynamic process that shaped the practice and the complementarity between the corporate HRM practices and macro-level institutions in carrying out such an assessment. 


\section{Notes}

1 See Ono (2005) for a comprehensive overview of the concepts and measurement of lifetime employment.

2 See also Chuma (1997) and Rebick (2001) for similar empirical assessments.

3 For the period 1923-36, the survey reported the separation rate of blue-collar workers in manufacturing establishments with 50 or more regular workers. For 1948-2002, the survey reported the separation rate of regular employees (blue-collar and white collar employees) in manufacturing establishments with 30 or more regular employees. Separation rate is defined by the number of employees who left an establishment due to voluntary quits, layoffs, and discharges, divided by the average number of employees.

4 See Ichniowski and Shaw (2003) for a comprehensive literature review.

5 As we discuss in detail later, there has been a development in case law precedents that restrict employers' right of dismissal to a certain degree.

6 Although it is beyond the scope of this chapter, other institutions, such as corporate governance and supplied relations, also affect the feasibility and effectiveness of HRM practices. See, for example, Aoki (1988) and Nishiguchi (1994).

7 For instance, in 1932 a male employee in a large establishment with ten years of tenure received the average retirement allowance worth 150 days' wages plus 30 days' pay in the case of voluntary retirement (Zensanren 1932a 1932b; Moriguchi 2003).

8 Union density is defined by the union membership divided by the total number of employees. Working days lost are defined by the number of days lost due to labor disputes accompanied by strikes and lockouts that lasted longer than half a day.

9 For the evolution of corporate HRM practices during World War II and the impact of wartime labor regulations, see Okazaki (1993) and Moriguchi (2000).

10 In the 1960s, however, employers promoted ability-based wages to provide work incentives. By the early 1970s, a majority of firms adopted hybrid wages or "seniority-plus-merit" pay that combined seniority with a prominent merit component based on performance evaluation by supervisors (Tsutsui 1998, 174).

11 The 1975 Supreme Court decision established a principle that an exercise of the right of dismissal must be based on "reasonable grounds" to receive general social approval (Nihon Shokuen Seizo, April 25, 1975, 29 Civ. Cases 456).

12 The 1979 court decision specified that employers had to (1) exhibit a high degree of business difficulties; (2) make an effort to take other measures, such as transfers and voluntary retirement, before resorting to adjustment dismissals; (3) use objective and fair standards in selecting workers to be dismissed; and (4) engage in prior discussion with workers in good faith even if no such provision existed in union contracts (Sugeno 1992, 408-9).

13 The bonus system dates back to the prewar period, but its beneficiaries were mostly high-ranking white-collar workers (Jones and Kato 1995). By 1985, 97 percent of firms with 30 employees or more paid half-yearly bonuses to their employees (Ministry of Labor statistics, cited in Ohashi 1989).

14 Membership increased from 730,000 in 1955 to 5.6 million in 1965 (Ministry of Labor statistics, cited in Takanashi 2002).

15 For example, the coefficient of dispersion for wage increases was 0.29 in 1956 but fell below 0.1 in the 1960s (Ministry of Labor statistics, cited in Takanashi 2002).

16 Inoki (2000) writes that by 1965 more than 95 percent of all households owned a black-and-white television set, and by 1970, 90 percent of households owned a washing machine and refrigerator. 


\section{Chiaki Moriguchi and Hiroshi Ono}

17 Empirical studies of the Japanese labor market have found a negative correlation between the number of job changes and earnings. See, for example, Kato and Rockel (1992) and Ono (2004).

18 See Brunello (1988) for a detailed analysis concerning how employers used employee transfers during the First Oil Shock.

19 However, the impact of the oil shock on employment adjustment was considerably smaller in Japan than in the U.S. A comparative study revealed that the manpower reduction measured by the number of employees involved in Japan was only one-third of that in the U.S. (Shinozuka 1978).

20 For example, the major shipbuilding firm Ishikawajima Harima Heavy Industries established an affiliated firm specializing in designing sound reduction construction machinery. Other manufacturing firms also ventured into real estate and other service sector industries (Cole 1979).

21 A survey of 805 firms listed in the Tokyo Stock Exchange and JASDAQ reported in Nihon Keizai Shimbun, February 26, 2002.

22 This view has been popularized in the media. See, for example, a Nihon Keizai Shimbun article entitled "Can Matsushita Come Back?" (August 4, 2001).

23 Nihon Keizai Shimbun (European Edition), November 18, 2001.

24 Exception 4 in the guideline reads: "Cases where recruiting or hiring is intended for workers under a certain age in situations where, in order to make wage payments regardless of age to new employees, companies will be required to revise present regulations determining wages mainly in accordance with age" (Japan Institute of Labor [2001a]).

\section{Bibliography}

Abegglen, James. 1958. The Japanese Factory. New York: Free Press.

Aoki, Masahiko. 1988. Information, Incentives, and Bargaining in the Japanese Economy. Cambridge: Cambridge University Press.

1990. "Toward an Economic Model of the Japanese Firm." Journal of Economic Literature 28: 1-27.

Ariga, Kenn, Giorgio Brunello, and Yasushi Ohkusa. 2000. Internal Labor Markets in Japan. Cambridge: Cambridge University Press.

Auer, Peter and Sandrine Cazes. 2000. "The Resilience of the Long-term Employment Relationship: Evidence from the Industrialized Countries." International Labour Review 139: 379-408.

Baker, George, Robert Gibbons, and Kevin J. Murphy. 1994. "Subjective Performance Measures in Optimal Incentive Contracts." Quarterly Journal of Economics 109: 1125-56.

Beck, J. C. and M. N. Beck. 1994. The Change of a Lifetime: Employment Patterns among Japan's Managerial Elite. Honolulu: University of Hawaii Press.

Brown, Clair and Reich, Michael. 1989. "When Does Union-Management Cooperation Work? A Look at NUMMI and GM-Van Nuys." California Management Review 31: 26-44.

Brunello, Giorgio. 1988. "Transfers of Employees Between Japanese Manufacturing Enterprises: Some Results from an Enquiry on a Small Sample of Large Firms." British Journal of Industrial Relations 26: 119-32.

Chuma, Hiroyuki. 1994. Kensho: Nihongata Koyo Chosei [Examining Japanese Employment Adjustment]. Tokyo: Shueisha.

1997. "Keizai kankyo no henka to chukonenso no choukinzokuka" ["Change

in the Economic Environment and Lengthening of Tenure for the Middle and 
Older Age Groups"]. In Hiroyuki Chuma and Terukazu Suruga (eds) Koyo kankyo no henka to josei rodo [Changing Employment Practices and Female Labour Force]. Tokyo: University of Tokyo Press, 47-82.

Cole, Robert E. 1971a. Japanese Blue Collar: The Changing Tradition. Berkeley: University of California Press.

1971b. "The Theory of Institutionalization: Permanent Employment and Tradition in Japan." Economic Development and Cultural Change 20: 47-70.

1979. Work, Mobility and Participation: A Comparative Study of American and Japanese Industry. Berkeley: University of California Press.

Coleman, J. 1990. Foundations of Social Theory. Cambridge, MA: Harvard University Press.

Crawcour, Sydney. 1978. "The Japanese Employment System.” Journal of Japanese Studies 4: 225-45.

Dore, Ronald. 1973. British Factory-Japanese Factory. Oxford: Alden Press.

1983. "Goodwill and the Spirit of Market Capitalism." British Journal of Sociology 34: 459-82.

Garon, Sheldon. 1988. The State and Labor in Modern Japan. Berkeley: University of California Press.

Genda, Yuji. 2000. "Youth Employment and Parasite Singles." Japan Labor Bulletin 39, 5-12.

Genda, Yuji and Marcus E. Rebick. 2000. "Japanese Labour in the 1990s: Stability and Stagnation." Oxford Review of Economic Policy 16: 85-102.

Gordon, Andrew. 1985. The Evolution of Labor Relations in Japan: Heavy Industry 1853-1955. Cambridge, MA: Harvard University Press.

Hashimoto, Masanori. 1993. "Aspects of Labor Market Adjustments in Japan." Journal of Labor Economics 11: 136-61.

Hashimoto, Masanori and John Raisian. 1985. "Employment Tenure and Earnings Profiles in Japan and the United States." American Economic Review 75: 721-35.

Hazama, Hiroshi. 1978. Nihon Romu Kanrishi Kenkyu [Historical Studies of Japanese Labor Management]. Tokyo: Ochanomizu Shobo.

Higuchi, Yoshio. 1999. "Rodo shijo no ryudoka wa naze susumanainoka?" ["Why doesn't labor market flexibility progress?"] Jurist 1149: 10-14.

Hyodo, Tsutomu. 1971. Nihon ni okeru Roshi Kankei no Tenkai [The Evolution of Labor-Capital Relations in Japan]. Tokyo: Tokyo Daigaku Shuppankai.

Ichinose, T. 2001. "Tenshoku ni yoru shogai chingin no gensho to soki taishoku yugu seido" ["Early retirement plans and the decline in lifetime income resulting from job changes"]. Rosei Jiho 3484: 27-34.

Ichniowski, Casey and Kathryn Shaw. 2003. "Beyond Incentive Pay: Insiders' Estimates of the Value of Complementary Human Resource Management Practices." Journal of Economic Perspectives 17: 155-80.

Ichniowski, Casey, Kathryn Shaw, and Giovanna Prennushi. 1997. "The Effects of Human Resource Management Practices on Productivity: A Study of Steel Finishing Lines." American Economic Review 87: 291-313.

Inoki, Takenori. 2000. "From Rapid Growth to the End of Full-time Employment in Japan: 1945-70.” In Richard T. Griffiths and Toshiaki Tachibanaki (eds) From Austerity to Affluence: The Transformation of the Socio-economic Structure of Western Europe and Japan. London: Macmillan Press, 82-98.

Japan Institute of Labor. 2001a. Guidelines to Abolish Age Limits in the Revised Employment Measures Law. Tokyo: Japan Institute of Labor. 


\section{Chiaki Moriguchi and Hiroshi Ono}

2001b. Reorganization of Businesses and Employment Adjustment Aimed at Middle-aged and Older Workers. Tokyo: Japan Institute of Labor.

2001c. Shitsugyo Kozo no Kenkyu [Structure of Unemployment]. Japan Institute of Labor Report 142.

Jones, Derek C. and Takao Kato. 1995. "The Productivity Effects of Employee Stock-Ownership Plans and Bonuses: Evidence from Japanese Panel Data." American Economic Review 85: 391-414.

Kandel, Eugene and Edward Lazear. 1992. "Peer Pressure and Partnership." Journal of Political Economy 100: 801-17.

Kanemoto, Yoshitsugu and Bentley MacLeod. 1992. "Reputation and Selfenforcing Labor Contract." Journal of the Japanese and International Economies 6: 144-62.

Kato, Takao. 2000. "The Recent Transformation of Participatory Employment Practices in Japan." NBER Working Paper No. 7965, Cambridge, MA.

2001. "The End of Lifetime Employment in Japan? Evidence from National Surveys and Field Research." Journal of the Japanese and International Economies 15: 489-514.

Kato, Takao and Motohiro Morishima. 2002. "The Productivity Effects of Participatory Employment Practices: Evidence from New Japanese Panel Data." Industrial Relations 41: 487-520.

Kato, Takao and Mark Rockel. 1992. "Experiences, Credentials, and Compensation in the Japanese and U.S. Managerial Labor Markets: Evidence from New Micro Data." Journal of the Japanese and International Economies 6: 30-51.

Kawakita, Takashi. 1997. "The Mid-career Unemployed in Japan.” Japan Labor Bulletin 36: 5-8.

Koike, Kazuo. 1988. Understanding Industrial Relations in Modern Japan. London: Macmillan Press.

1991. Shigoto no Keizaigaku [The Economics of Work]. Tokyo: Toyo Keizai Shimposha.

1997. Human Resource Development. Tokyo: Japan Institute of Labor.

Koshiro, Kazutoshi. 1983. "Development of Collective Bargaining in Postwar Japan.” In T. Shirai (ed.) Contemporary Industrial Relations in Japan. Madison: University of Wisconsin Press, 205-57.

2000. A Fifty Year History of Industry and Labor in Postwar Japan. Tokyo: Japan Institute of Labor.

Kyochokai. 1924. Hompo Sangyo Fukuri Shisetsu Gaiyo [Overview of Industrial Welfare Facilities in Japan]. Tokyo: Kyochokai.

1926. Wagakuni ni Okeru Rodo Iinkai Seido [Labor Committees in Japan]. Tokyo: Kyochokai.

1929. Saikin no Shakai Undo [Recent Social Movements]. Tokyo: Kyochokai.

MacDuffie, John Paul. 1995. "Human Resource Bundles and Manufacturing Performance: Organizational Logic and Flexible Production Systems in the World Auto Industry." Industrial and Labor Relations Review 48: 197-221.

Milgrom, Paul and John Roberts. 1995. "Complementarities and Fit: Strategy, Structure, and Organizational Change in Manufacturing." Journal of Accounting and Economics 19: 179-208.

Ministry of Health, Labor and Welfare (MHLW). 2001. Survey on Labor Economy Trends. Tokyo: MHLW. 
Ministry of Labor. 1969. Rodo Gyoseishi [History of Labor Administration], volume 2. Tokyo: Roob Horei Kyokai.

Moriguchi, Chiaki. 2000. "The Evolution of Employment Relations in U.S. and Japanese Manufacturing Firms, 1900-1960: A Comparative Historical and Institutional Analysis.” NBER Working Paper No. 7939, Cambridge, MA.

2003. "Implicit Contracts, the Great Depression, and Institutional Change: A Comparative Study of U.S. and Japanese Employment Relations.” Journal of Economic History 63: 625-65.

Nihon Rodo Undo Shiryo Iinkai. 1959. Nihon Rodo Undo Shiryo [Historical Data of Japanese Labor Movement], Volume 10. Tokyo: Chuo Koron Jigyo Shuppan.

Nishiguchi, Toshihiro. 1994. Strategic Industrial Sourcing: The Japanese Advantage. Oxford: Oxford University Press.

Nishinarita, Yutaka. 1988. Kindai Nihon Roshi Kankei-shi no Kenkyu [Historical Study of the Modern Japanese Labor-Capital Relations]. Tokyo: Tokyo Daigaku Shuppankai.

Noguchi, Yukio. 1994. Bubble no Keizaigaku [Economics of the Bubble]. Tokyo: Nihon Keizai Shimbunsha.

Ohara Shakai Mondai Kenkyusho, 1964. Taiheiyo Sensoka no Rodosha Jotai [Labor conditions during the Pacific War]. Tokyo: Toyo Keizai Shinposha.

Ohashi, Isao. 1989. "On the Determinants of Bonuses and Basic Wages in Large Japanese Firms." Journal of the Japanese and International Economies 3: 451-79.

Okazaki, Tetsuji. 1993. "The Japanese Firm under the Wartime Planned Economy." Journal of the Japanese and International Economies 7: 175-203.

Ono, Hiroshi. 2002. "Japanese Labor Market Reform: Why is it so Difficult?" In Fixing Japan's Economy: Proceedings of the Japan Information Access Project Symposium. Washington DC, April 2002.

2004. "College Quality and Earnings in the Japanese Labor Market." Industrial Relations 43: 595-617.

2005. "Lifetime Employment in Japan: Concepts and Measurements." Paper presented at the National Bureau of Economic Research Conference, Tokyo, Japan, September 2005.

Ono, Hiroshi and Marcus E. Rebick. 2003. "Constraints on the Level and Efficient Use of Labor." In Magnus Blomström, Jennifer Corbett, Fumio Hayashi and Anil Kashyap (eds) Structural Impediments to Japan's Economic Growth. Chicago: NBER and University of Chicago Press, 225-57.

Osterman, Paul. 1994. "How Common is Workplace Transformation and Who Adopts It?" Industrial and Labor Relations Review 53: 173-87.

Rebick, Marcus E. 1998. "The Japanese Labor Market for University Graduates: Trends in the 1990s." Japan Forum 10: 17-29.

2001. "Japanese Labor Markets: Can We Expect Significant Change?" In M. Blomström, B. Gangnes, and S. La Croix (eds) Japan's New Economy: Continuity and Change in the Twenty-First Century. Oxford: Oxford University Press.

Recruit Works Institute. 2001. Working Persons Chosa 2000: Shutoken [Working Persons Survey 2000: The Greater Tokyo Area]. Tokyo: Recruit.

Sako, Mari and Hiroki Sato. 1997. Japanese Labour and Management in Transition: Diversity, Flexibility and Participation. London and New York: Routledge.

Shakaikyoku. 1936. Taishoku Tsumitatekin oyobi Taishoku Teate Hoan Yoko oyobi Shiryo [Summary and Documents of the Retirement Allowance Fund Law]. Tokyo: Naimusho Shakaikyoku. 


\section{Chiaki Moriguchi and Hiroshi Ono}

Shimada, Haruo. 1979. "The Japanese Labor Market after the Oil Crisis: A Factual Report." In Structural Determinants of Employment and Unemployment, Vol. 2. Paris: OECD.

1988. Humanware no Keizaigaku [Economics of "Humanware"]. Tokyo: Iwanami Shoten.

1992. "Japan's Industrial Culture and Labor-Management Relations.” In S.

Kumon and H. Rosovsky (eds) The Political Economy of Japan, Vol. 3: Cultural and Social Dynamics. Stanford: Stanford University Press.

1994. Nihon no Koyo [Japanese Employment]. Tokyo: Chikuma Shobo.

Shinozuka, Eiko. 1978. "Koyo Chosei no Mondaiten" ["Problematic Points Concerning Employment Adjustment"]. ESP 72 (April).

Shirai, Taishiro. 1983. Contemporary Industrial Relations in Japan. Madison, WI: University of Wisconsin Press.

1992. Gendai Nihon no Romu Kanri [Labor Management in Modern Japan]. Tokyo: Toyo Keizai Shimposha.

Showa Dojinkai. 1960. Wagakuni Chingin Kozo no Shiteki Kosatsu [Historical Survey of Japanese Wage Structure]. Tokyo: Shiseido.

Sugeno, Kazuo. 1992. Japanese Labor Law. Seattle, WA: University of Washington Press.

Tachibanaki, Toshiaki and Tomohiko Noda. 2000. The Economic Effects of Trade Unions in Japan. London: Macmillan Press.

Tackney, Charles. 1995. "Institutionalization of the Lifetime Employment System: A Case Study of Changing Employment Practices in a Japanese Factory." Ph.D. Dissertation, Industrial Relations, University of Wisconsin-Madison.

Takanashi, Atsushi. 2002. Shunto Wage Offensive. Tokyo: Japan Institute of Labor.

Tsuda, Masumi. 1968. Nenkoteki Roshi Kankei-ron [Security-based LaborManagement Relations]. Tokyo: Minerva Shobo.

Tsuru, Tsuyoshi. 2002. Roshi Kankei no Nonyunion-ka [Nonunionization of Labor-Management Relations]. Tokyo: Toyo Keizai Shimpo.

Tsutsui, William. 1998. Manufacturing Ideology: Scientific Management in Twentieth-century Japan. Princeton, NJ: Princeton University Press.

Vogel, Ezra. 1963. Japan's New Middle Class: The Salary Man and His Family in a Tokyo Suburb. Berkeley, CA: University of California Press.

Yamamoto, Kiyoshi. 1991. Nihon no Rodo Sogi [Labor Disputes in Japan], 1945-1980. Tokyo: Tokyo Daigaku Shuppankai.

Zensanren. 1932a. Wagakuni ni okeru Kaiko Teate Seido no Genjo [Current Conditions of Dismissal Allowance Plans in Japan]. Tokyo: Zenkoku Sangyo Dantai Rengo.

1932b. Wagakuni ni okeru Romusha Taishoku Teate Seido no Genjo [Current Conditions of Retirement Allowance Plans in Japan]. Tokyo: Zenkoku Sangyo Dantai Rengo. 


\title{
7 The Japanese labor movement and institutional reform
}

\author{
Lonny E. Carlile
}

\section{Introduction}

What has the role of the labor movement been in the process of institutional change in Japan, and what role is it likely to play in the current process of institutional reform? Given the deeply ingrained image of the Japanese labor movement as "cooperative" unions subservient to management, perhaps this is not a question that comes readily to mind when thinking about the process of institutional change in contemporary Japan. However, the fact remains that despite a dwindling rate of union density, in terms of sheer membership numbers Japanese unions remain the country's largest organized mass interest group and, thanks to the practice of automatic dues check off, unions remain a major source of funding for political parties as well as a source of candidates. Furthermore, if we extend our gaze overseas, there are numerous precedents for unions acting as a major force in shaping the process of institutional change in both the political and economic arenas, in particular where marketizing institutional reforms of the sort that are being pursued in Japan today are involved. In this sense, the engagement of unions certainly has the potential to become an important factor in the process of institutional reform.

In light of these concerns, this chapter explores the changing nature of the labor movement's general stance toward the process of institutional change in Japan. In doing so, it builds upon and attempts to extend Moriguchi and Ono's game theory-grounded analysis of the institutional dynamics of the so-called Japanese employment system in Chapter 6 of this volume. It does this by interpreting the so-called Japanese employment system as the axis of a "social contract" whose terms and implementation provide the key to understanding attitudes and behavior on the part of the Japanese labor movement toward the institutions of the Japanese political economy and its stance, and its role in the process of institutional change.

Building on prior work in the field of Japanese political economy most notably that of Watanabe (1990), Garon and Mochizuki (1993), Gordon (1993, 1998), McNamara (1996), Shinoda (1997), Kume (1998), Schwartz (1998) and - the body of the chapter begins with an overview of 


\section{Lonny E. Carlile}

the relationship between the labor movement and institutional change prior to the emergence of the centralized "social contract." Pages 183-9 discuss the social contract that has governed the political economic terms of engagement on the part of the mainstream Japanese labor movement until recently and the way in which it has defined labor's stance and role toward institutional reform from the late 1970s onward. Pages 189-98 provide an analysis of the public stances adopted by Rengo (the Japan Trade Union Confederation), the organization that has been the dominant national center for the Japanese labor movement since its formation in 1989. It advances the argument that recent changes in labor's stance toward institutional reform in the political economic arena are being spurred by the perception that the other parties have abandoned the social contract. Finally, the chapter ends with a number of concluding comments on the contingencies under which unions' preferences are likely to matter in the process of reform.

\section{The labor movement and institutional change, 1945-75}

There is a certain systematic relationship between the development of labor movements and institutional change. While there are arguably exceptions, historically labor movements have originated as would-be agents of institutional change. They arise because the leadership of the new movement interprets existing institutions to be contrary to the interests of the workers who constitute the actual or would-be rank and file of the movement and the movement itself expands by harnessing the sense of alienation that workers possess vis-à-vis the institutional status quo. (A notable exception would be corporatist "movements" created in top-down fashion by authoritarian or totalitarian regimes.) Just how severe and widespread this alienation is depends on the specific social and historical circumstances, as does the means espoused by labor movement leaders to overcome this alienation, with the strategies ranging from moderate incremental reformism to wholesale political, economic, and social revolution (Lipset 1983). Whether or not institutional change unfolds in accordance with the program of one or another wing of the movement, societies are forced to engage in institutional innovation of some kind in order to adjust to the reality of politically and/or economically organized workers. Over time, there has often been an interactive interplay between institutional change and attitudinal and behavioral changes in the labor movement. As institutional changes are implemented that respond to labor movement demands and work to reduce the level of worker alienation, labor movements typically begin to accept the general parameters of the political economic status quo while abandoning goals of revolutionary sociopolitical transformation in favor of incremental, non-systemic change through institutionalized channels. The precise modality through which this adaptation unfolds, in turn, profoundly affects the institutional arrangements that characterize a modern industrial economy. 
The historical trajectory of the Japanese labor movement exhibits a pattern that parallels that of many European movements in the way that it began as a movement with a strong orientation toward institutional change - albeit with a high degree of ideological division internally - with wings ranging from ultranationalists on the right to communists on the left. The strength of the labor movement's pressure on behalf of highly transformative institutional renovation in both politics and economics was at its zenith during the years between 1945 and 1960 as the labor movement - or more accurately the dominant communist and then left socialist wings of the movement - positioned itself as the core of a broad anti-establishment movement aimed at a wholesale alteration of Japan's domestic political economic institutions (i.e. varying shades of vaguely defined "socialism") and of the political and diplomatic apparatus that sustained the status quo (i.e. conservative governance and Japan's Cold War alliance with the United States). Over the ensuing years, however, this radicalism abated as institutional innovation accommodated labor's interests within the context of Japan's democratic polity and capitalist economy. By the early 1980s, analysts were pointing to a "neocorporatist" incorporation of the Japanese labor movement. Where earlier it had directed its energies toward a major alteration of the status quo of the Japanese industrial relations system - a "countervailing force" (gegenmacht) to use the German terminology - the labor movement was now acting as a "force of order" (ordnungsfaktor) defending the established institutional apparatus of the now wellentrenched institutionalized order surrounding the Japanese employment system.

There is a considerable literature that details how this occurred. Although conceptualizations and details vary, the essence of the process described in the literature can be captured, as Garon and Mochizuki (1993) have done, through the lens of the social contract model. A contract defines the basic parameters of the relationship between the contracting parties by stipulating expected and prohibited behavior. These parameters, in turn, are intended as a means by which to realize a mutually beneficial exchange of some kind and the foreseen benefits provide the basis for each party's willingness to abide by the contract's stipulations. A simple example that illustrates these attributes is a contract in which a seller agrees to deliver to a buyer a given amount of a specified product by a certain date in exchange for an amount of money to be transferred by the buyer to the seller upon delivery. Such examples are, of course, basic to the functioning of a market and are quite familiar. Social contracts are more complicated and more difficult to grasp for several reasons. One reason is that social contracts are abstract constructs developed by analysts. While the codification of a social contract can occur, the parties involved are not necessarily conscious of the existence of the contract even though they might pattern their behavior and infuse the way they think about and discuss the relationship involved. A second reason is that the 
"parties" are, more often than not, multiple large organizations that are characterized by a complex internal dynamic of their own. Fixing "responsibility" for the fulfillment of a social contract's terms can therefore be a challenging intellectual and practical task. Third, the benefits that are "exchanged" in a social contract are far broader and more abstract (social order, sustained economic growth, etc.) than in a typical market contract, making social contracts that much more amorphous. Fourth, they are implemented through complex social institutions, thereby raising the complexity of social contracts yet another notch. Finally, and this is perhaps more a product of engrained intellectual habit than of social contracts per se, social contracts typically link behaviors and involve an exchange of benefits that span across what are habitually conceived of as the independent arenas of "civil society," "market," and "state," thus making them less readily capturable through conventional disciplinary and subdisciplinary tools. Such analytical border crossing is particularly well entrenched in social contracts involving labor movement organizations, because unions and their affiliated organizations are by nature simultaneously market players and political entities.

The "parties" to what we shall term the Japanese employment social contract are: (1) the core segment of the Japanese labor movement rooted in regular employees in the large corporate sector and whose interests are articulated by the leadership of the currently hegemonic national labor center, Rengo; (2) the segment of the business community whose interests have traditionally been represented in Nikkeiren (which very recently merged with the industry peak association Keidanren); and (3) the politicians and state bureaucrats in the mainstream of Japan's conservativedominated political establishment who are most actively involved in the labor policy decisions and their implementation. With respect to the scope of its coverage, the contract establishes behavioral parameters in intrafirm industrial relations practices, state labor policymaking, macroeconomic policy, and social movement mobilization. The primary interests served by the social contract can be described as follows. For the labor movement, it is the way in which the social contract addresses its concerns in the areas of maintaining employment security, sustaining and raising worker income levels, and in assuring socioeconomic equity among and for workers. For management, it is the flexible and cost-effective allocation of labor and a stable macroeconomic business environment. And for state bureaucrats and the politicians, it is social and political stability.

Historically, the Japanese employment social contract arises from a process of long-term evolution that dates back to the mid-1950s. At this time executives in Japan's large manufacturing firms were confronted with the need to revamp their industrial relations systems in order to accommodate new industrial technologies and production administration methods that they were importing from the U.S. and other advanced industrialized countries. This need, furthermore, was occurring in a context where labor 
unions had become firmly implanted in the Japanese political economy thanks to Occupation period labor reforms. It was necessary under the circumstances to engineer the consent of the workforce vis-à-vis these changes and to do so through unions (Gordon 1993, 1998). A boilerplate of a mechanism for working through this generic problem was put forward by a tripartite organization, the Japan Productivity Center (JPC, Nihon Seisansei Honbu), that was established in 1955 and modeled after similar institutions established in Western Europe during the late 1940s and early 1950s. The Center's was a twofold prescription. On the one hand, it put forward what it called "the three principles of productivity," the essence of which can be paraphrased as follows: (1) industrial innovations that increased labor productivity are in the long run in the economic interest of both workers and economy and society more generally; (2) in the process of implementing labor productivity-increasing innovations worker dismissals should be avoided as much as possible through the use of ameliorative measures like job transfers that preserve the employment of affected workers; and (3) that workers are entitled to a "share" of the increased returns made possible by productivity-enhancing innovations. The second aspect of the Productivity Center's prescription was the use of labor-management consultation committees (keiei kyogikai) as organs for inputting union concerns into the process of industrial innovation and for gaining labor union acquiescence or, better yet, active cooperation (Nihon Seisansei Honbu 1985; Tsutsui 1998). In essence, what the JPC championed was a "social contract" in which employment security and a limited voice in the process of industrial innovation were exchanged for labor union cooperation in industrial upgrading.

The fact that the organizational unit for implementing industrial innovation was the firm and that the firm-level enterprise union had emerged as the dominant organizational form for Japanese unions meant that the firm was the logical site for the conclusion of such "productivity bargains." In line with this, labor-management consultation committees and industrial relations practices reflecting the JPC's productivity principles spread rapidly in steel, petrochemicals, and other industries where technological innovation was unfolding on a large scale. More often than not, the unions in these firms proved willing to enter into such bargains since they were viewed by the more moderate elements therein as a reasonable mechanism by which to assure employment for the members of the union and to expand the size of the net corporate revenue "pie" from which wage increase slices would be cut. Nevertheless, in a significant number of instances existing unions resisted, and following defeat in a major labor-management confrontation they were replaced by more cooperative "second unions" willing to accept the terms of a productivity bargain being put forward by management. Though rarely codified, firmlevel "social contracts" of this type became a prevailing practice in Japan's leading industries by the mid-1960s and provided a set of norms that were 


\section{Lonny E. Carlile}

a microeconomic foundation for the long-term viability for lifetime employment, seniority wages and other elements of the Japanese employment system in this class of firms.

While firm-level productivity bargains of this sort promised sizable gains to unions in those sectors where massive, labor productivityenhancing investments were under way, they were by nature less attractive to unions outside of these sectors. This was because, pressed to their logical conclusion, they implied toleration of large gaps in wage levels between industries where significant labor productivity increases were possible and those where they were not. This cut against the grain of labor movement principles of wage equity across industries. It is within this context that we can see the significance of another critical institutional innovation in Japanese industrial relations that emerged in the mid-1950s, the Shunto, or Spring Struggle (Sako 1997; Takanashi 2002). Shunto refers to the annual rounds of coordinated company-level bargaining campaigns around which collective bargaining in Japan is built. Under the Shunto system unions in an industry establish identical wage demands, coordinate strikes and other dispute action tactics, and bargain simultaneously with their respective managements. There were two basic purposes behind these "scheduled struggles." One was to increase the bargaining power of labor by consolidating the strength of individual enterprise unions and incorporating their actions into a common campaign. The other was to induce a wage-leveling effect by coordinating bargaining across industries. Industries where the highest wage gains were anticipated were designated to be the "top batters" in the hope that large wage gains won early in these industries would lift up the level of wage increases won in subsequent bargaining. Shunto thus embodied a quest for social equity via its intended wage leveling effect. In the event, Shunto proved to be a great success. This was indicated by the ever-expanding roster of Shunto participants. Assisted by the rapid economic growth and a tightened labor market of Japan's "economic miracle," by the end of its first dozen years Shunto, as a semi-formalized institution, spread well beyond the Sohyo-affiliated unions in large, private sector manufacturing firms to encompass public sector workers (whose wage increases were officially tied to the results of private sector Shunto wage hikes beginning in 1964), the unions of its more moderate rival Domei and even to workers in the largely unorganized small and medium-sized enterprise sector. As a consequence of Shunto, despite a labor market truncated by lifetime employment practices and a decentralized collective bargaining system in which formal wage negotiations are conducted independently by enterprise unions and their respective firms, a highly integrated wage market emerged that effectively tied wages in lagging sectors to the wage gains attained in the most advanced high-productivity sectors. The leveling effect that is apparent in the shrinking variance indexes of annual Shunto settlements (see

Takanashi 2002, 5, 75-9.). In this way, Shunto provided a sociopolitical 
corrective to the inegalitarian tendencies that were built into the firm-level productivity bargains. The simultaneous spread of firm-level productivity bargains and Shunto wage bargaining practices - the former a consensuallyarrived-at social contract at the firm level and the latter constituting regularized and ritualized labor-management conflict at the macro level established an institutionalized framework in which class conflict was channeled and defused in a way that was consistent with the economic growth policies being pursued by the Japanese state. The sociopolitical utility of this stabilization of class conflict was acknowledged by the ruling conservatives. Where the LDP leadership tended earlier to take a stand hostile to Shunto, by the mid-1960s its attitude turned favorable. The "labor-management harmony" found in the Japanese employment system, in particular, was singled out as a uniquely superior product of the Japanese social milieu. When we look at the development of this process from the standpoint of the labor movement's relationship toward institutional change in the Japanese political economy, what we see is a process of institutional innovation focused on intrafirm industrial relations institutions and collective bargaining institutions that served to win labor movement acceptance of post-World War II Japanese capitalism.

\section{The neo-corporatist social contract and institutional change, 1975-90}

While this initial firm-level implementation of the productivity bargain, together with Shunto, allowed Japanese firms in leading industrial sectors to effectively implement the massive capital investment programs that they had mapped out, set in motion a growth-stimulating ripple effect across the economy, brought stability to Japanese industrial relations generally, and contributed to enhanced macroeconomic growth, political stability and social order, there was a latent macroeconomic problem built into the system that grew increasingly apparent over the course of the 1960s. In particular, the problematic character of the expanding Shunto system, with its encouragement of a leveling up of all wages relative to those being won in the most productive industries, began to be felt in the early 1970s, as signs of wage-push inflation began to be seen. The contradictions inherent in the system came to a head as both labor and management were forced to come to terms with the additional adverse consequences of the First Oil Crisis.

What emerged from the explosive wage hikes and inflation of 1974-75 was an alteration in the principles governing Shunto that in effect established a de facto incomes policy through the application of the productivity principles on a national scale (Kume 1988). Specifically, rather than tying wage hikes to the rate of productivity increases in industries where productivity gains were the greatest, Shunto wage bargaining was now to be implicitly tied to the rate of labor productivity in the national economy 


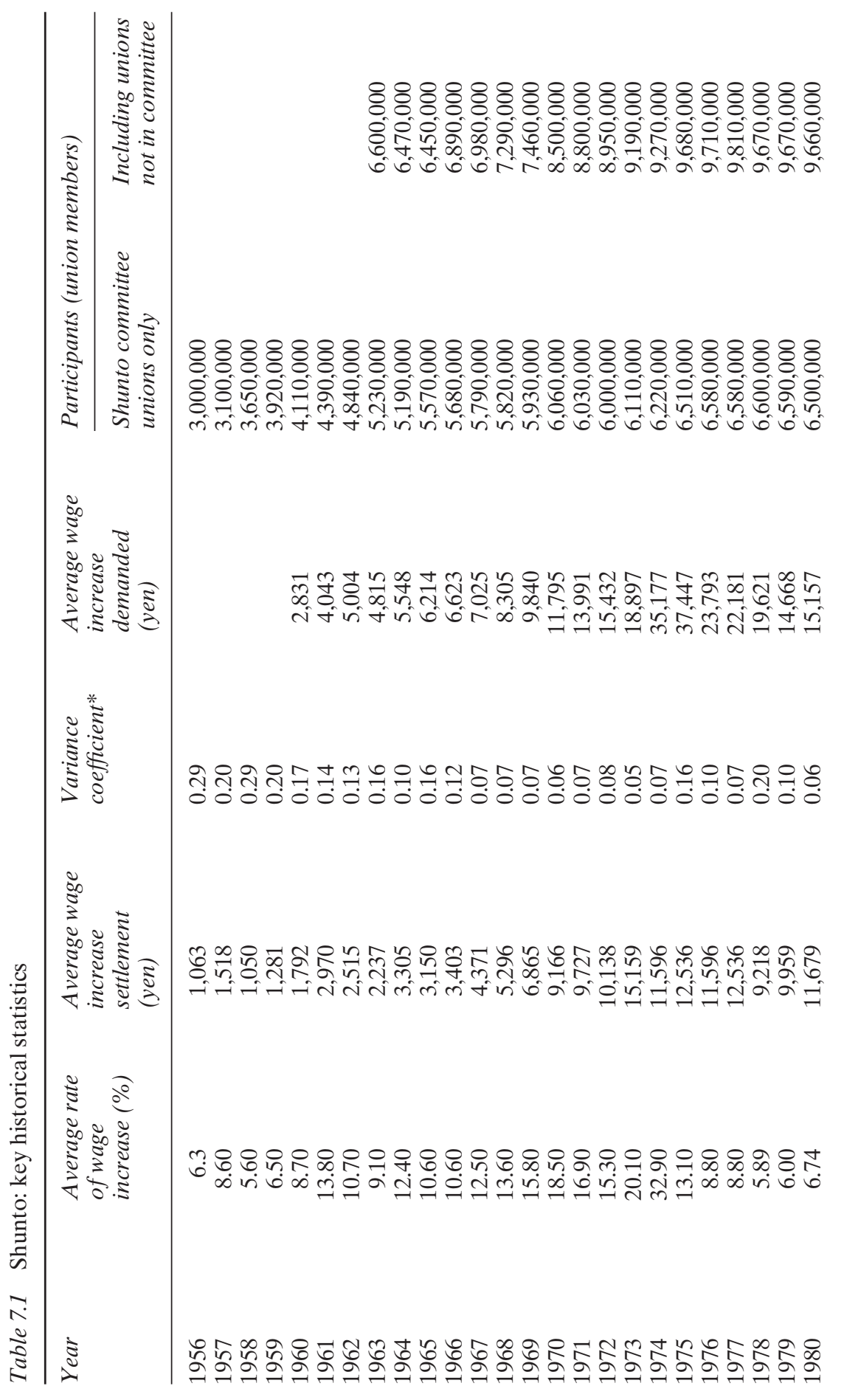




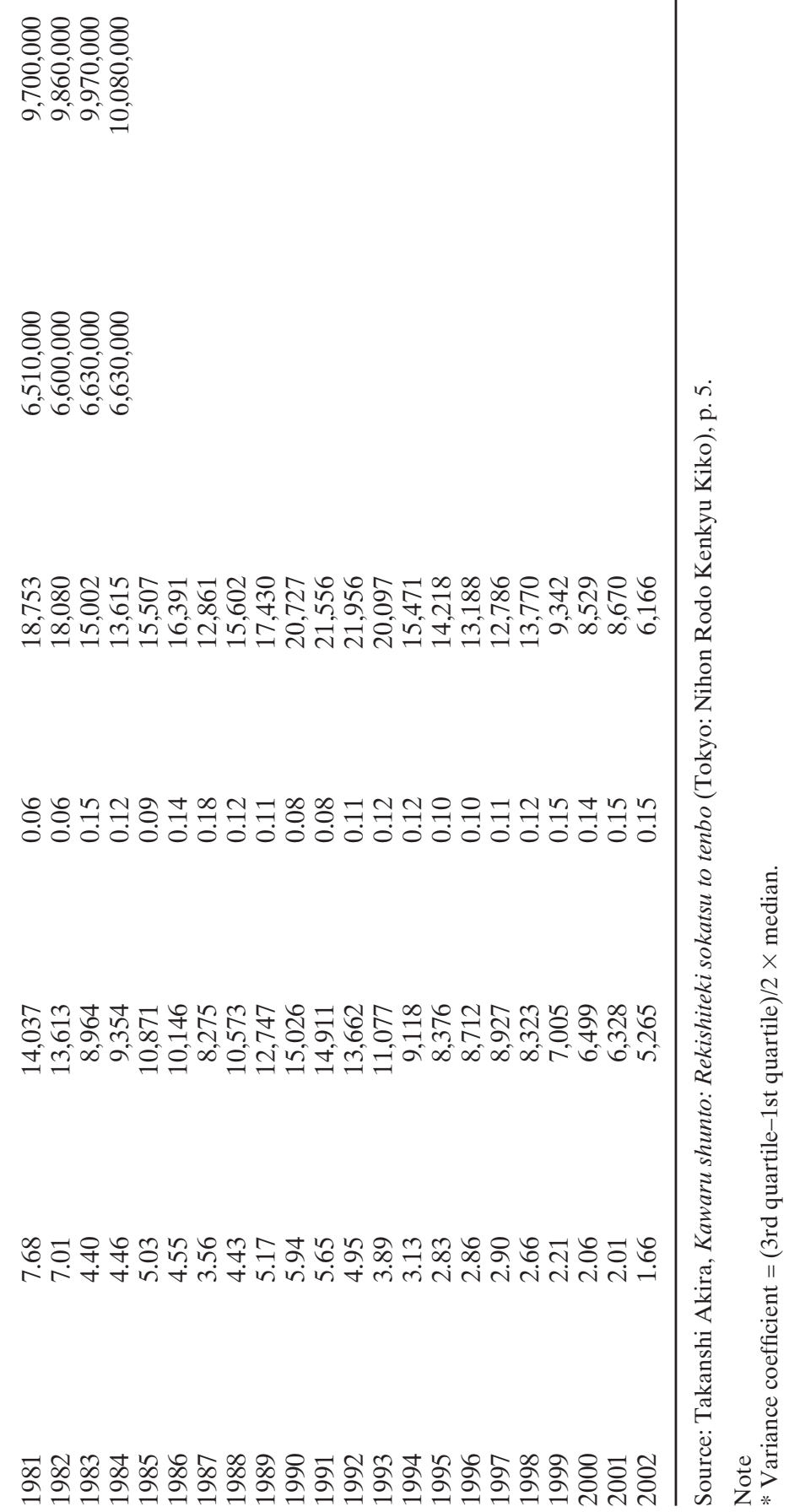


as a whole. In exchange for moderation in wage demands, business, through the protection of regular employee jobs, agreed in effect to sustain lifetime employment and other attributes of the Japanese employment system. In addition, in exchange for the moderation of union wage demands, the government agreed to implement a number of programs designed to sustain the employment of unionized employees under conditions where adverse economic conditions were pushing to the point where informal mechanisms of adjustment were no longer enough for employers to retain workers. A number of special measures, described by Moriguchi and Ono in Chapter 6 of this volume, were adopted to protect workers from loss of employment in industries undergoing structural decline. The state, in short, was given the added function of using specific labor policy measures to sustain the Japanese employment system.

These Oil Crisis-induced adjustments were accompanied by an alteration of the programmatic agenda of the unions, the stage for which was set during the 1960s by a shift in the balance of power inside the labor movement away from more radical unionists based in the public sector to more moderate, productivity-oriented unionists in the private sector. Still, prior to the mid-1970s, the more radical, left socialist wing under the national center Sohyo remained a formidable force within the labor movement, while the moderate elements associated with Sohyo's rival, Domei, were nominally committed to a social democratic line that implied substantial alterations in the political economic institutions that had been established under the ruling conservatives. It was not until the early 1980s that one can meaningfully speak of a coming to terms on the part of the labor movement with the existing institutions of the Japanese political economy (see Carlile 1994; Shinoda 1997; Kume 1998). The two key indicators of the Japanese labor movement's "corporatization" were the de facto declarations of support by moderate labor leaders for a neoliberal institutional reform agenda promoted by Prime Minister Yasuhiro Nakasone in the early 1980s, and the rise to hegemony in the labor movement by these moderate elements by the mid-1980s. The acceptance of the neoliberal reform agenda was preceded, in the wake of the Oil Crisis in the mid-1970s, by the adoption of a new approach to wage demands on the part of unions that were concerned about what they perceived to be the wage-push inflationary approach to Shunto as it had been pursued up to that point. Under conditions where inflation fears made it inadvisable to continue to demand large wage hikes, these unions came to embrace a strategy in which they pressed for tax cuts on the reasoning that doing so would raise the net income of workers without putting pressure on corporate balance sheets. The core concept of this new approach to the pursuit of worker welfare was that of the "welfare society" (as opposed to a welfare state) wherein an employee's welfare was to be attained as much as possible from social institutions like the employment system, with as little reliance as possible on the state. 
This gradually led to their embrace of the high-profile movement for administrative reform promoted by Rincho (the Second Extraordinary Commission on Administrative Reform) in the early 1980s that pursued a variety of mechanisms to reduce the size of government, including the privatization of the state-run railways and the state-owned national telephone monopoly. Not surprisingly, this put the moderate unionists on a collision course with the more radical public sector unions. With the help of changing government policies that forcibly reduced the power and influence of public sector unions, the moderate private sector unions that were supportive of the Rincho agenda gradually gained control of the Japanese movement. Moderate hegemony was already apparent in the early 1980s when a movement to unify the labor movement under private sector union principles began to gather steam. It was unmistakable by 1989 when the remaining public sector unions merged with the private sector unions to form the currently dominant national center, Rengo (Carlile 2003).

There has been considerable debate in the field of Japanese labor politics over whether it is appropriate to consider the labor movement an "included" social partner in a "neo-corporatist" regime in the sense that the term has been used to describe the situation of the labor movement in a number of West European politics. Until the mid-1980s, the prevailing assessment was that put forward by Pempel and Tsunekawa in a classic article (1979). They maintained that there was a system of neo-corporatist consultation in Japan but it was one from which the labor movement had been largely "excluded." From the mid-1980s onward, however, students of Japanese labor politics (notably, Kume 1998) have argued that a kind of neo-corporatism that included the labor movement did indeed emerge during the latter half of the 1970s.

The differences between the two sides in this debate have perhaps been exaggerated as a result of a failure to appropriately contextualize and delimit the claims being made. The labor movement has, in a sense, been an "included" interest group in labor policymaking since the inclusion of union representatives on a variety of dispute settlement and advisory commissions in the labor policy field as a result of the Occupation period labor reforms. Until the mid-1960s, however, the prevailing tendency was for governments of the ruling LDP either to ignore labor's viewpoint or to adopt an outright confrontational stance toward labor on major labor policy issues. The stance of LDP governments began to change somewhat following the 1964 "summit" meeting between Prime Minister Ikeda Hayato and Sohyo's Ota Kaoru in which the government promised to automatically link public sector wage increases to those obtained by the private sector during the annual rounds of Shunto wage negotiations. By the latter half of the 1970s and during the 1980s in particular, elements of a "neo-corporatist" arrangement could be seen in the way that the LDP government and the administrative bureaucracy began to include labor representatives in a wider range of governmental commissions and, more 


\section{Lonny E. Carlile}

informally, to regularly consult the labor movement in a wider range of policymaking arenas. Nevertheless, even at the height of the "Japanesestyle neo-corporatism" of the 1980s one would have had a difficult time arguing that the labor movement's role in the policymaking process was as a full-fledged "social partner." At best, full social partnership in Japan was present in the labor policy arena. In other policy areas labor's voice was never loud enough or institutionalized firmly enough to sustain the comparison (notably, Knoke et al. 1996).

The problem rested in the particular configuration of interest group-government relations that characterized LDP rule in the 1970s and 1980s. This configuration in turn molded the labor movement's stance and role in the process of institutional change. To place the issue in the framework of the social welfare society model that the mainstream of the labor movement has been promoting since the mid-1970s, one could say that the labor movement has been unable to obtain the needed relative influence in a sufficiently broad range of policymaking arenas to fully realize the welfare society model. While support for the neo-liberal administrative reform movement put labor on the side of big business, agricultural policy, small business policy, and public works budgeting were all captured by groups whose interests more often than not were directly counter to the proverbial salary man that the labor movement claimed to represent (Carlile 1998). In other areas like social welfare, fiscal policy and industrial policy, despite inroads, labor's voice had simply not been listened to sufficiently for even the more conservative elements in the mainstream labor movement to consider themselves firmly ensconced in a social partner position. It is for this reason that the labor movement consistently supported parties like the Japan Social Democratic Party, the Democratic Socialist Party, and the Democratic Party that have championed major alterations of the status quo. But this, in turn, sustained a certain distance and mistrust between the ruling conservatives and the labor movement mainstream that prevented the two sides from cementing a fully secure and fully stabilized political relationship (Carlile 1994).

The product of this not-fully-integrated neo-corporatism was the emergence of a distinctive modality for pressing for institutional change to which the labor movement has attached the label of "policy and institutional struggle" (seisaku seido toso) (Shinoda 1997). A list of "policy and institutional demands" - priority legal, regulatory and policy innovations that the labor movements would like the government to implement - is compiled annually (currently triannually). The list covers a broad range of policy areas extending from employment regulations and labor policies narrowly defined to such matters as fiscal and financial policy, industrial policy, educational policy and environmental policy. The resulting document, which includes extensive commentary justifying its proposals, is typically over 150 pages in length and in light of its bulk is often referred to as the "telephone book." The national center then lobbies the government, 
political parties, and sympathetic interest groups in an effort to get these proposals realized. Through this process, the movement's demands for extra-firm institutional and policy changes are in effect melded into the regularized channels and procedures of policymaking associated with longterm LDP rule. As one of many competing interest groups - and not necessarily a particularly powerful one in relative terms - the labor movement's ability to effect major changes is limited and any institutional changes won are typically delimited by compromise and are marginal in character. But with the core concerns of its primary rank-and-file membership perceived to be secured by the institutions of the Japanese employment system, this arrangement, though frustrating at times, was perceived to be reasonably satisfactory from mainstream labor's view.

\section{From business as usual to a new paradigm? Adjusting to the post-bubble recession, 1991-2003}

Japan's overheated Bubble Economy burst in 1991. Confronted with a financial system in disarray, a stagnant economy, and with the yen rapidly appreciating, by the mid-1990s Japanese firms were under great pressure to cut costs in order to remain solvent. These same years coincided with the appearance of renewed political momentum on the part of the neoliberal reform movement originally associated with Rincho (Carlile 1998; La Croix and Mak 2001). Deregulation and administrative reform were propelled to the forefront of the public agenda amid strong international pressures and a seemingly unceasing flood of corruption scandals involving government bureaucrats. Several concrete proposals for a drastic overhaul of Japan's economic regulatory structure were released that portended even more intense cost pressures. In the meantime, unemployment had risen to unprecedented levels, primarily as a consequence of cutbacks in the secondary workforce and drastic cuts in new hiring. With the conventional means of adjusting corporate workforces during downturns exhausted, a number of prominent business spokespersons began during the mid-1990s to talk openly about the need for even more "flexibility" in their use of the labor force. The deteriorating economic circumstances and the political and administrative instability induced Rengo to assess the implications of these circumstances and to consider what an appropriate response on its part might be. A number of major public statements and policy documents were released during the 1994-96 period in which the national center presented its reading of the situation and outlined what it saw as the appropriate short-term, medium-term and long-term directions for the Japanese labor movement in light of these developments.

Among the most immediately useful for the purpose of gauging the impact of this rethinking on Rengo's attitude toward the social contract on employment is a November 1994 report entitled "The Direction of Employment and Labor Countermeasures During the Period of 


\section{Lonny E. Carlile}

Transition" (Weekly Rengo 1994). The discussion therein is premised on the assumption that the strains faced by large corporations were not merely cyclical but rather the symptoms of a major structural problem. The report sets out medium- and long-term strategies by which to manage the required structural adjustments. In doing so the report clearly reveals a desire to work within the parameters stipulated in the employment social contract. It points out that although "lifetime employment" applies only to the 20 to 30 percent of the workforce employed in large corporations and the government and public sector, it also serves as a model for labormanagement relations in small and medium-sized enterprises. The report argues that lifetime employment contributes to effective corporate operations by encouraging employee identification with the firm and associates it with a heightened work incentive. Given this, it asserts the importance of maintaining the employment system and argues that therefore the labor movement's responses should center on promoting employment policies geared toward preventing increases in unemployment that might destabilize that system. At the same time, the document also makes it clear that preserving employment does not mean resisting structural changes. On the contrary, structural change is presented as the vehicle for solving employment problems. This logic echoes the JPC's classic three principles of productivity. After observing that "deregulation' is bringing about an alteration of the industrial structure," it asserts that "the loosening of economic regulations contains within it the prospect of working as a positive force for future economic growth and the expansion of employment opportunities through improved service, declining price levels, and the appearance of new industries." It admits that deregulation can give rise to the negative side-effect of employment loss, but it need not do so if addressed properly. If appropriate pro-competitive "social regulations" are instituted in a balanced way in tandem with deregulation, then unemployment should not be a concern. Rengo then makes it clear that primary responsibility for such "social regulation" rests with the firm:

Changes in industrial structure are accompanied over the mediumterm by the movement of labor from business segments that are shrinking to business segments that are growing.... For this reason, the first thing that needs to be done is to shift currently employed workers to new jobs. In the event that a reduction in the firm's size is unavoidable, it is the firm's responsibility to arrange a job to transfer to and to guarantee opportunities to obtain appropriate job training.

(Weekly Rengo 1994, italics added)

Rengo conceded, however, that the magnitude of the required structural transformation was such that conventional adjustments within the confines of the firm-level effort alone were unlikely to be sufficient in absorbing the excess labor that the transition would generate. The upshot of this was the 
delineation of a massive "employment creation plan" that provided a unified solution to the tasks of securing new jobs for currently employed workers, of creating new jobs for the unemployed and of raising real living standards for Japanese workers. Under this plan, tripartite industry- and national-level state-labor-management consultation committees would facilitate investment in new technologies and business fields. Five specific sectors were targeted: telecommunications, housing and transportation infrastructure, cultural industries (including leisure and education), health care, and the environmental/energy sectors. The choice of these particular sectors was deliberate, in that they were all viewed as sectors that would contribute to improvements in the living standards of Japanese workers. The development of housing and transportation industries was billed as a way to improve Japanese lifestyles by outfitting workers with more convenient and comfortable housing and means of travel. The expansion and upgrading of the health care industry was presented as a way to simultaneously increase employment and deal with the rapidly increasing need for health care services growing out of the ongoing rapid rise in the proportion of the elderly in Japan's population. Investment in the culture, education and leisure industries was presented as a way to enrich the lives of workers in parallel with reductions in work hours. A similar slant was projected onto the discussion of the environmental and information-telecommunication sectors (Rengo 1995). In this sense, the proposals were very much in line with the post-1975 modus operandus of the mainstream labor movement that utilized policy innovations as mechanisms for raising the real workers' incomes without burdening corporate balance sheets.

Actual policy developments in fact closely followed the scenario outlined in Rengo's 1994 employment policy report. In 1995 Rengo and Nikkeiren (the Japan Federation of Employers' Associations) held a series of seminars to discuss policies that could be adopted to encourage expansion of these targeted industrial sectors and jointly lobbied the government on behalf of relevant policies. Although somewhat pro forma, the government did establish an employment creation headquarters and packaged various policy initiatives that could be argued to be in the spirit of the employment creation plan into a government initiative.

As detailed in the preceding section, another key aspect of the early 1980s social contract was the labor movement's support, in alliance with business, of the neoliberal economic reform agenda championed since the heyday of Rincho. During the mid-1990s Rengo continued to back this line on institutional change, as is illustrated by Rengo's 200-page compilation of policy and institutional demands for the 1994-95 period (Rengo 1994). In this report, Rengo declared its commitment to the goal of establishing a "free, fair and transparent system in which the market mechanism will function in a positive way." Increased competition was characterized as being in the worker's interest because it would lower consumer prices and thereby raise worker incomes in real terms. In keeping with earlier 


\section{Lonny E. Carlile}

reports, tax cuts were pushed as a means for increasing worker incomes and as a way of stimulating the consumer spending needed to lift the economy out of recession. It was also presented as a way to correct the long-standing overemphasis in Japan on investments in firm capital over investments in public and private assets used to support private and public consumption.

The way in which these various tendencies fit together into an overall strategy is exemplified in the annual Shunto strategy report for 1996 (Rengo 1996, 10-11). Rengo once again presents economic growth as the solution to economic decline. It establishes a 3 percent growth rate as a target to be attained through coordinated labor-state-management efforts ("Government, labor and management must strive for economic recovery and improvements in living standards and must move to 3 percent real growth that is unaccompanied by employment insecurity") (p. 10). In the division of labor that it outlines, government is assigned the task of implementing a "bold" fiscal stimulus package, policies to stabilize the exchange rate, and policies to facilitate a "reform of the economic and industrial structure." Labor and management, in the meantime, are to work together in the development of new industries that would help to "create employment" while improving working conditions. Neoliberal market reforms, to be pressed for through Rengo's institutional and policy struggles for the fiscal year, are presented as a means of eliminating employment pressures. ("Structural countermeasures are absolutely necessary if high unemployment and expanding [income] differentials are to be eliminated. We will advance reforms that lead in the direction of a fair and vital society, like deregulation that stimulates [economic] vitality and improved living standards, corrections of price differentials that show consideration for consumers, and welfare measures that will lead to an aging society without worries") (p. 10).

Despite the substantial weight given to these institutional and policy demands, however, pushing up wages was clearly the central concern in the 1996 Shunto strategy. Rengo called on its constituent units to "engage in efforts to raise the [Shunto] market" and negotiate industry-level wage hikes that would "increase their synergetic effect" using the conventional mechanisms for conducting Shunto campaigns developed over the preceding four decades. The methodology put forward for formulating wage demands was very much in keeping with the incremental, social contractoriented practices adopted since 1975. Wage demands were to consist of three components: a regular wage hike component, a component tied to inflation, and a living standards improvement component. The first component corresponded to the regular seniority- and merit-based salary increases that corporations had presumably already incorporated into their labor costs and would not therefore have a major impact on the overall corporate bottom line. The inflation component, of course, was consistent with the principle of calibrating wage hikes to larger macro- 
economic trends. The remaining living standards improvement component, too, was ultimately justified as being consistent with trends in the overall economy. Rengo argued that an increase was necessary to compensate for declining interest income caused by dropping interest rates and, of course, as a means of generating the consumer demand needed to get the economy growing again. That the spirit of 1975 was very much alive was perhaps nowhere better exemplified than in the following long-winded headline of an article in a special section of Rengo's official monthly devoted to the 1996 Shunto: "It is important to get back on a re-expansion track by aiming for an increase in consumption through aggressive wage hikes without extinguishing the fire in the engine of plant and equipment investment" (Suzuki 1996).

Thus, key documents produced by Rengo during the mid-1990s support the conclusion that the mainstream of the Japanese labor movement sought solutions to the challenges of the period within the parameters of the post-1980 social contract. This strategy positioned the labor movement in a stance supportive of the neoliberal institutional reform agenda that was being promoted - albeit ultimately with mixed success - by a coalition of big business and reformist elements in government and politics. It did so because it continued to conceive of the labor movement's interests as being served by the Japanese employment system and because it considered Japanese management to be willing to abide by the terms of the social contract and to work with the labor movement in promoting solutions that were in the mutual interest of both parties.

During the latter part of the decade, and in particular after 1997, it became increasingly apparent that the terms of the debate over employment and structural reform in Japan were changing rapidly. Despite massive fiscal stimulus packages aimed at jumpstarting a recovery, Japan experienced negative economic growth rates of -0.4 in 1997 and -1.9 percent in 1998. (An increase in the consumption tax and the Asian Financial Crisis contributed to these negative growth rates.) The steady rise in the number of unemployed, which had continued unabated since the burst of the bubble, picked up steam and eventually broke through the psychologically significant rate of 5 percent in 1999. The new hiring of permanent employees appeared to be a dying practice, while corporate restructurings accompanied by major workforce reductions were occurring with alarming frequency. Some of Japan's largest corporations were included in this group. Perhaps the most symbolically significant of these was that which was occurring at the automaker Nissan, a company that had a reputation for having a powerful enterprise union. In 1999 the company announced a plan to reduce its workforce by 14 percent, or some 21,000 employees, and the number of suppliers that it dealt with by half. The latter action sounded the probable death knell for the small and medium-sized manufacturers involved and the jobs of their workers. What made the Nissan case all the more jarring, however, was that all of this was occurring under 


\section{Lonny E. Carlile}

the watch of Carlos Ghosn, a Frenchman. What this seemed to imply was that "Western"-style labor force reduction had now gained a firm foothold in Japan.

The effect of the economic deterioration was to pull the rug out from under the increasingly strained consensus on employment and neoliberal reform that had provided the foundation for the accommodation between the state, the business community, and the labor movement. To proponents of neoliberal economic reform, and for many Japanese corporate executives, the employment-preserving practices of the Japanese employment system were no longer sustainable and a new approach to employment was required. During 1999, it became clear that the earlier taboo on open discussion of abandoning the Japanese employment system could no longer be enforced (Shukan rodo nyusu, 1999b). In February the prestigious and influential Economic Strategy Council called for the creation of "a healthy and creative competitive society." In conjunction with this proposal it recommended that employment policy move away from its existing approach of encouraging firms to retain employees to one that stressed raising the employability of individual workers in the external labor market. In July another prestigious government council articulated a similar vision in which it recommended employment policies focused on actively encouraging labor mobility. And finally the government's 1999 Economic White Paper cited employment along with capacity and debt as the "three excesses" that Japan needed to trim and, for the first time in the 45-year history of such White Papers, carried an estimate of the total excess employees in the country. In October 1999 Keidanren weighed in with a militant-sounding policy statement of its own in which it asserted that "there is a need to correct the problem of labor policies decided in commissions becoming compromises between labor and management." Like the earlier governmental commissions, it called for employment policies that, rather than encouraging long-term employment, would instead facilitate labor mobility. What these various statements implied was that there was an increasing willingness in the Japanese policymaking establishment to abandon the Japanese employment system based on the notion of long-term employment in favor of a highly individualized, highly fluid, "flexible" model of employment.

The willingness on the part of prominent management and government spokespersons to state publicly that they were willing to abandon the employment social contract prompted Rengo officials to reconsider their position. One of the earliest indications that a major rethink was under way was made evident at Rengo's biennial convention held in October of 1999 (Shukan rodo nyusu 1999b). There, "employers who were not making an effort to live up to their social responsibility" were roundly chastised. The Economic Security Council's "leave-everything-to-themarket thesis" was also raised as a specific target of severe criticism. Strong objections were voiced against the notion that Japanese corpora- 
tions had an "excess" of employees. The situation was instead characterized as one in which cutbacks in hiring and the reduction in the number of secondary workers were forcing regular employees to work an excessive number of hours. The practice of "service overtime" (unpaid overtime work) was singled out for criticism. In the ensuing months, a number of ideas and concepts - some of them new and others presented earlier but not emphasized - were pushed to the forefront of Rengo's public discourse. Perhaps the broadest, and for that reason most fundamental, was the idea of a "labor-centered welfare society." As the discussion in preceding sections indicates, the "welfare society" concept was not a new one and was in fact central to the post-1980 employment social contract. However, during 1999-2000 its content underwent a metamorphosis. Where earlier Rengo had thought in terms of workers realizing their welfare needs collectively through the firm via a more or less autonomously administered employment system, it now downgraded the role played by the firm in favor of an approach in which the workers as individuals would seek to maintain their welfare through "society." Though somewhat lengthy, the following elaboration of the "labor-centered welfare society" in Rengo's official journal provides a succinct explication of what was involved:

What we hold as our ideal is a society in which an individual's independence and freedom are guaranteed on the base of a secure and stable foundation in which one can have confidence about what is ahead. What we put forward as the ingredient is the vision of a "labor-centered welfare society." The challenge taken up in the EU and social democracy in Europe can be considered to be one such effort.

A secure and stable foundation for a working person is first and foremost stability of employment. If an individual is to sustain an independent lifestyle and if there is to be an expansion of the range of choices available in choosing one's modality of work there must be a foundation of stable, long-term employment. The long-term employment practices that have been established in Japan must be considered a social safety net whose significance extends beyond a firm's internal employment policy. In addition, with the decrease in the number of work hours, increases in holidays, and a lengthening of life spans, the time available outside of work hours and one's productive years will expand and increase in importance. From now on, we must focus on the local community and seek a welfare society system whose boundaries extend beyond the firm as we move in the direction of shifting from enterprise-centered welfare to social welfare, and at the same time labor unions themselves must become the primary overseer of the welfare society.

(Rengo 2000a, 8) 
The conceptual shift away from the firm as the primary vehicle for attaining worker welfare opened the way for considering new modalities for managing an employee's relationship with the firm. In place of the informal guarantees of employment that were the hallmark of the Japanese employment system, Rengo proposed a "labor contract law" and a "law for the protection of workers on the occasion of enterprise reorganization" that would legally codify the terms under which dismissals can occur and make worker rights explicit. Rengo also began to champion the concept of "work sharing," a key component of which was the elimination of unpaid overtime ("service overtime") for the sake of expanding employment opportunities. An outside study estimated that doing so would create work for 900,000 employees. If paid overtime were eliminated as well this figure would increase to 2.3 million (Shukan rodo nyusu 1999b).

Outside of the firm, Rengo began to champion an overhaul of Japan's social welfare system. Whereas it had earlier tended to view the role of state-sponsored welfare arrangements as supplemental to firm-sponsored programs, it began to speak of a need for "universality" and "normalization" in state social welfare policy and to argue for a consolidation of Japan's motley collection of social welfare programs that targeted various population groups separately. One must hasten to add that even as it called for an expanded state welfare role, Rengo distinguished what it sought from a classic welfare state. It did this by insisting that the expanded state social welfare role be paralleled by an expansion of employment opportunities that keep people off social assistance while lightening the pressure on the government's fiscal resources (Rengo 2000a, 8).

This shift away from the firm to an increased emphasis on state welfare provisions, in turn, precipitated an alteration in its stance toward the neoliberal administrative reform movement. In its "2001-2003 Policy and Institutional Demands Summary," Rengo (2001) stressed that marketization is but a means to an end and not an end in and of itself, and pointed to the need for firewalls that would prevent liberal reforms from resulting in a ravaging of employment and work conditions: "At present, with globalization as a motivating factor, the 'market-as-cure-all thesis' and 'market fundamentalism' have taken the day. Policies that attempt to leave everything to the market will expand social inequities and will sap economic vitality over the long run. The market cannot operate effectively in the absence of clear cut rules and safety nets" (p. 6). It insisted that " administrative reform' should not simply aim for 'small government,' but for 'government that is effective and efficient' and can appropriately respond to society's needs." The issue is not so much the size of government or even the expansion of the scope of the market mechanism, but making the political economy - that is, market and state together - as responsive as possible to the livelihood and welfare needs of workers. Rengo envisioned a fairly radical transformation in order to bring this about: "We believe that the national government should conduct affairs related to the exist- 
ence of the state in international society and be responsible for measures that are national in scope while local governments engage in a wide range administration that is close to their resident populations, and that government administration should restrict the activities of the private sector as little as possible" (p. 118). It then went on to demand a thoroughgoing devolution of power from the national to local governments on the justification that local governments are much more sensitive and responsive to the needs of the citizenry. This, in turn, encouraged a more solidaristic orientation in the way that Rengo defined its primary constituency. Whereas earlier there was a tendency to focus its efforts on the needs of the regular employees of large corporations that constituted the unionized segment of the Japanese workforce, Rengo began to more energetically champion the cause of part-time workers, temporary workers, and female employees (pp. 43-8).

As with our preceding discussion of Rengo's stance in the mid-1990s, the most recent Shunto strategy document (the Rengo "white paper") provides a useful illustration of the way in which these various elements fit together (Rengo 2002). Where the earlier version saw a coordinated labor-government-management strategy as the solution to Japan's economic woes, the 2003 Shunto white paper conveys a profound loss of faith in labor's ostensible social partners. Rather than providing a solution to the problem, management and government are presented as the cause of the problem. Thus, regarding management, the document noted that "employers have intensified their efforts to secure short-term profits by cutting personnel expenditures, by suppressing wage increases and making employment adjustments [i.e. dismissing employees]. This business behavior had generated a vicious macro spiral: workers' anxiety about jobs and living suppresses private consumption, which reduces demand and makes the market sluggish, in turn undermining corporate performance." Its assessment of government is equally harsh: "The Government has not even made efforts to take effective policies to dispel workers' anxieties about jobs, such as proper unemployment countermeasure[s] or an expansion of safety nets. On the contrary, the government is unilaterally imposing the 'pains' of its structural reforms on working people, by shifting onto them the additional unemployment insurance and health insurance burdens ... and by carrying out deregulation in a reckless way. Moreover, the government has accelerated the process of bad loan settlement, adding to the already strong deflationary pressure" (p. 58).

Looked at through the lens of the social contract model, what these statements suggest is that in Rengo's view both employers and the government are not living up to the terms of the employment contract. Shortly before the release of Rengo's 2003 white paper, Nippon Keidanren (a new joint employer/business association created from a merger of Keidanren and Nikkeiren) released a report on labor policy. Commenting on what it felt to be the Nippon Keidanren report's willingness to reduce costs at the 


\section{Lonny E. Carlile}

expense of worker well-being, the Rengo white paper, using moral economy language, stated flatly that "Nippon Keidanren here abandons its responsibility as the most powerful employers' association and defers real solutions to an indefinite future" (p. 24). Similar sensibility is expressed when Rengo's president calls on the government in his preface to the white paper "to play its proper role for the creation of jobs and stability of employment" (p.3).

This perceived breakdown in the socio-contractual relationship between the labor movement, on the one hand, and employers and government, on the other, is presented in the Rengo 2003 Shunto white paper as cause for a reorientation of Rengo's strategy or, to use Rengo's language, "reconstruction of the Spring Struggle." Shunto's reconstruction is characterized as an eminently political task - that of establishing a new "social consensus" behind the goal of establishing a "welfare society centered on work." Wage increases receive extremely little mention. Instead, policy and institutional demands predominate. And whereas earlier policy demands and industrial relations concerns were conceived as independent arenas, in the 2003 Shunto white paper institutional measures were identified as the lever for precipitating institutional change in the industrial relations arena. And, rather than tacitly accepting differential treatment between the unionized labor elite and the non-unionized secondary labor force, the 2003 Shunto places assistance to the bottom of the ladder in a central place.

\section{Conclusion}

The current chapter reviewed, in broad strokes, the way in which the Japanese labor movement's attitude and stance evolved over time as both the movement and the Japanese adjusted to the development of an industrial and post-industrial capitalist political economy, as well as the more recent extended downturn in economic growth. Institutional change was central to this process. It was also maintained that looking at this process in terms of a "social contract" provides a fruitful means of understanding the distinctive configuration of institutions, attitudes and behavior patterns that surround the so-called Japanese employment system and shape the larger dynamics of the polity and economy in that country. I argued that the labor movement began as a movement that was fundamentally hostile to the institutional status quo and devoted to altering the institutions of the Japanese political economy in a substantial way. The emergence of a "productivity bargain" at the firm level, the institutionalization of the Shunto wage bargaining system, and the employment security provided to the bulk of the unionized workforce through the Japanese employment system combined to moderate the stance and then to alter the thrust of the Japanese movement. In the late 1970s, this gave birth to a de facto social contract that brought the mainstream of the Japanese labor movement 
into the establishment as a "social partner," albeit one whose position and role therein was characterized by a number of important limitations. This brought the movement to a stance in which it was generally supportive of the institutional status quo in the industrial relations arena. However, outside of the industrial relations arena the labor movement, together with big business, emerged as a force pushing for neoliberal change, albeit through means that were largely intra-systemic. Finally, it was argued that recent developments suggest that the labor movement sees the social contract as having lost its validity due to the actions of the other principals to the contract - business and government. This, in turn, appears to be precipitating a break with business on the neoliberal reform agenda and an attempt to forge an alternative vision of Japanese society that moves away from the firm-centered collectivism of the Japanese employment system to one in which the state intervenes more directly in assuring the welfare of the individual even as the movement clings to the notion of a welfare society over that of a welfare state.

As to what impact this current rethinking of labor's interest will have on the future direction of institutional issues in Japan, there are a number of possible directions in which things might go, but it is too early to say with any degree of confidence which one it will be. A renewal of the social contract and a reinforcement of current institutional arrangements are not inconceivable, although this would appear to be unlikely unless there is a rapid turnaround in Japan's economy. The bigger determining factor would appear to be that of the power and influence of the labor movement's vision in Japanese politics. On the one hand, it would appear that Rengo's emerging vision does effectively articulate the general interest of the average salary man and the employed population that is now the dominant part of the Japanese electorate. On the other, however, the kind of market liberalization that is such an important component of the welfare society vision would fundamentally endanger other "social contracts" governing relations between the state, the dominant LDP, and politically powerful interest groups like farmers and small-businessmen. Furthermore, in an archetypal not-in-my-back-yard response, individual unions and union industrial federations are also prone to oppose liberalization when their own industries are involved. Rengo has for years been attempting to forge a "new political force" in the form of a new political party that would represent the interests of the employee and that could wrest control of the government from the grip of entrenched interests that now block the path to a neoliberal/social welfarist institutional restructuring (Carlile 1994). However, here too Rengo has been perennially frustrated. In the absence of an effective political force of this type, Rengo will, no doubt, continue to press for this vision, while confronting opposition from a big business community bent on establishing more "flexibility" in its control over labor, and from entrenched vested interests (including its own member organizations). 


\section{Bibliography}

Calder, Kent. 1988. Crisis and Compensation: Public Policy and Political Stability in Japan, 1988. Princeton, NJ: Princeton University Press.

Carlile, Lonny. 1994. "Party Politics and the Japanese Labor Movement: Rengo's 'New Political Force'." Asian Survey, 24-7 (July 1994): 301-16.

Carlile, Lonny. 1998. "The Evolution of the Administrative Reform Movement: The Politics of Japanese Regulatory Reform." In Lonny E. Carlile and Mark Tilton (eds) Is Japan Really Changing Its Ways? Regulatory Reform and the Japanese Economy. Washington, DC: Brookings Institution Press, 76-110.

Carlile, Lonny. 2003. "The Japanese Labour Movement's Road to the Millennium." In David W. Edgington (ed.) Japan at the Dawn of the New Millennium. Vancouver: University of British Columbia Press, 49-66.

Garon, Sheldon and Mike Mochizuki. 1993. "Negotiating Social Contracts." In Andrew Gordon (ed.) Postwar Japan as History. Berkeley, CA: University of California Press, 145-66.

Gordon, Andrew. 1993. "Contests for the Workplace." In Andrew Gordon (ed.) Postwar Japan as History. Berkeley, CA: University of California Press, 373-94.

Gordon, Andrew. 1998. The Wages of Affluence: Labor and Management in Postwar Japan. Cambridge, MA and London: Harvard University Press.

Knoke, David, Franz Urban Pappi, Jeffrey Broadbent, and Yuataka Tsujinaka. 1996. Comparing Policy Networks: Labor Politics in the U.S., Japan and Germany. Cambridge, England and New York: Cambridge University Press.

Kume, Ikuo. 1988. "Changing Relations Among the Government, Labor and Business in Japan After the Oil Crisis." International Organization, 42-4: 659-87.

Kume, Ikuo. 1998. Disparaged Success: Labor Politics in Postwar Japan. Ithaca, NY and London: Cornell University Press.

La Croix, Sumner and James Mak. 2001. "Regulatory Reform in Japan: The Road Ahead." In Magnus Blomström, Byron Gangnes, and Sumner La Croix (eds) Japan's New Economy: Continuity and Change in the Twenty-First Century. Oxford and New York: Oxford University Press, 215-41.

Lipset, Seymour Martin. 1983. "Radicalism of Reformism: The Sources of Working Class Politics." American Political Science Review, 77: 1-18.

McNamara, Dennis. 1996. "Corporatism and Cooperation Among Japanese Labor." Comparative Politics, 379-97.

Nihon Seisansei Honbu. 1985. Seisansei undo 30 nenshi. Tokyo: Nihonse Seisansei Honbu.

Pempel, T. J. and Keiichi Tsunekawa. 1979. "Corporatism Without Labor? The Japanese Anamoly." In Philippe C. Schmitter and Gerhard Lehmbruch (eds) Trends Toward Corporatist Intermediation. London and Beverly Hills: Sage, 231-70.

Rengo. 1994. 1994 nen - 95 nen seisaku seido yokyu to teigen. Tokyo: Nihon Rodo Sorengo.

Rengo. 1995. "Tokushu: 100 man nin koyo soshutsu daisakusen ga ugokidashita." Rengo, 9 (6): 2-4.

Rengo. 1996. "Shunki seikatsu toso kihon koso." Rengo 8-9 (December 1995): 10-11.

Rengo. 2000a. "2000 Shunki seikatsu toso BOOK." Rengo 12-11 (February 2000): 2-11. 
Rengo. 2000b. “'Rodo o chushin to shita fukushigata shakai' o mezasutameno yottsu no kiiwaado." Rengo 13-8 (November 2000), 9-10.

Rengo. 2001. 2001-2003 nendo "seisaku seido yokyu to teigen." Tokyo: Nihon Rodo Sorengo.

Rengo. 2002. The Spring Struggle for a Better Life 2003. Rengo White Paper 2002. Tokyo: JTUC-Rengo. Online. Available at: www.jtuc-rengo.org. Accessed December 13, 2002.

Sako, Mari. 1997. "Shunto: The Role of Employers and Union Coordination at the Industry and Inter-Sectoral Levels." In Mari Sako and Hiroshi Ito (eds) Japanese Labour and Management in Transition: Diversity, Flexibility, and Participation. London and New York: Routledge, 236-64.

Schwartz, Frank. 1998. Advice and Consent: The Politics of Consultation in Japan. Cambridge, England and New York: Cambridge University Press.

Shinoda, Toru. 1997. "Rengo and Policy Participation: Japanese-Style NeoCorporatism?" In Mari Sako and Hiroshi Ito (eds) Japanese Labour and Management in Transition: Diversity, Flexibility, and Participation. London and New York: Routledge, 187-214.

Shukan rodo nyusu. 1999a. "1999 nen no 'koyo to rodo': Kozo kaikaku to koyo kiki ni yureugoku (1)." December 13.

Shukan rodo nyusu. 1999b. "1999 nen no 'koyo to rodo': Kozo kaikaku to koyo kiki ni yureugoku (2)." December 13.

Suzuki, Fujiikazu. 1996. "Sekkyokutekina chin'age de shohi no zoka o hakari, setsubi toshi no enjin no hi o tayasazuni sakakudai no kido ni noseteiku koto ga juyo." Rengo 8-10 (January): 13-15.

Takanashi, Akira. 2002. Kawaru shunto: rekishiteki sokatsu to tenbo. Tokyo: Nihon rodo kenkyu kiko.

Tsutsui, William. 1998. Manufacturing Ideology: Scientific Management in Twentieth-Century Japan. Princeton, NJ: Princeton University Press.

Upham, Frank. 1987. Law and Social Change in Postwar Japan. Cambridge, MA: Harvard University Press.

Watanabe Osamu. 1990. Yutakana shakai: Nihon no kozo. Tokyo: Rodo junposha. Weekly Rengo. 1994. "Sangyo kozo no henbo to koyo rodo mondai: Tenkanki no koyo rodo taisaku no hoko / koyo bijon no sakutei ni mukete." (December 9, 1994). As reproduced in Japan Institute of Labor clipping file. Online. Available at: db.jil.go.jp/jnk01/dtldsp?detail=W19941209006. Accessed August 16, 2003. 


\section{The changing pattern of Amakudari appointments

\author{
The case of regional banks, \\ 1991-2000
}

Kenji Suzuki

\section{Introduction}

Amakudari is one of the practices, or informal institutions, ${ }^{1}$ most frequently mentioned in the literature of Japanese political economy. Amakudari means 'descent from heaven', which describes the reemployment of the officials retired from the government (= heaven) into senior management positions in private companies. ${ }^{2}$

Since amakudari is likely to cause favouritism between the regulators and the regulated, it is formally regulated by law. The National Civil Service Law prohibits the reemployment of the retired officials into the private companies until two years after their retirement, if they have worked for national organizations closely related to those companies in the past five years. However, it is also provided that this prohibition does not apply if the National Personnel Authority (NPA) waives it after an investigation. Yet the NPA only investigates the cases of high-ranking officials, and each ministry may give permission for the reemployment of others. Furthermore, many officials are often employed in public corporations or other non-private organizations immediately after their retirement and spend two years in these jobs to avoid an NPA investigation. In short, the law only prevents very direct connections, allowing the whole system to survive without much impact from regulation. Traditionally, Japanese society has generally been tolerant toward amakudari, as it seemed to contribute to the country's successful economic development in some ways.

Amakudari has, however, been severely discredited since the collapse of the Bubble Economy in the early 1990s. This is partly because the social credibility of bureaucratic management has been reduced due to the longstanding economic slump, the exposure of many bribery scandals, and partly because the scope of regulatory control has been reduced as a result of deregulation. Consequently, some indicators have started to show a decline of amakudari practices in recent years. One of those indicators is the number of NPA agreements (see Figure 8.1). The number of amakudari fell to roughly 50 in recent years, a dramatic reduction from the more 


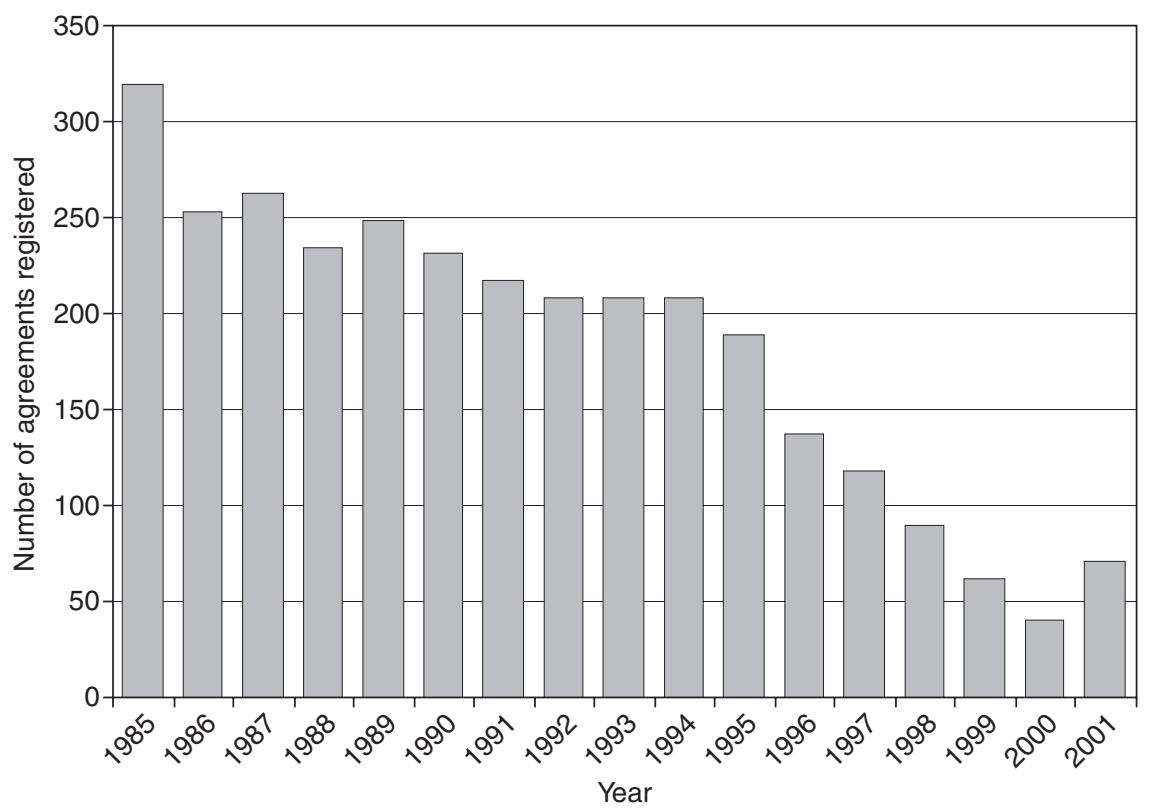

Figure 8.1 Number of agreements registered by the National Personnel Authority for amakudari, 1985-2001 (source: National Personnel Authority, various years).

than 300 appointments in 1985. Although the numbers may partly reflect a tendency to bypass these agreements, the extent of the change is remarkable. Another indicator is the number of retired officials reemployed in executive positions in listed companies, provided by Kigyo Keiretsu Souran (Toyo Keizai Shimposha), a private publisher. According to this source, the number of newly reemployed officials in the listed companies fell from 77 in 1988 to 55 in $1998 .^{3}$

While it may be significant to consider how the 'real' number of amakudari cases has changed, the present study aims to examine qualitative, rather than quantitative, changes. However, it does not examine all types of practice, partly because of the difficulty in collecting all relevant information, and partly because the pattern of amakudari seems to vary from one type to another, and a holistic examination may obscure important industry-specific findings. Thus, this study focuses on amakudari in regional banks, ${ }^{4}$ a specific but important case. There are several reasons for this choice. First, regional banks are major destinations for officials retiring from the Ministry of Finance (MOF) and Bank of Japan (BOJ). Reflecting its broad jurisdictional scope, MOF, as well as the Ministry of International Trade and Industry, was the most representative actor in the amakudari system (Okimoto 1988, 320; 


\section{Kenji Suzuki}

Ikuta 1995, 81). The destinations of its retirees were thus widespread, ${ }^{5}$ but regional banks were one of the most prominent destinations, against the background of the ministry's supervisory role (at least until the advent of the Financial Supervisory Agency in 1998). Regional banks were also the major destination for BOJ retirees, despite the lack of a direct regulatory relationship between the BOJ and regional banks. ${ }^{6}$

Second, there was a significant change in the trend of amakudari appointments to regional banks, both from the MOF and from the BOJ. This seems to have resulted very typically from a reduction in the social credibility of bureaucratic management and in the scope of regulatory control, which may have caused some qualitative changes in the pattern of amakudari (see page 210).

Finally, it is important to clarify the mechanism of this connection between financial authorities and regional banks, in order to understand Japan's ongoing economic crisis. Although national political discussion often focuses on a few very large banks, regional banks as a group intermediate a significant proportion of Japanese savings. While the largest seven banks accounted for 47 per cent of the deposits of all banks, in 2001, regional banks as a whole accounted for 45 per cent (Japanese Bankers Association 2002). ${ }^{7}$

There have already been a number of studies focusing on the amakudari practices from the MOF and BOJ into regional banks (Rixtel and Hassink 1998; Horiuchi and Shimizu 2001; Suzuki 2003). The first two studies were based on data up to the early 1990s. The last study uses data through the 1990s, and examines how the presence of amakudari executives affects the management behaviour of banks. This study attempts to shed light on the pattern of amakudari appointments into regional banks and the change in the pattern over time.

The rest of the chapter is organized as follows. The next section discusses four perspectives for understanding amakudari practices. Pages 209-12 investigate the trend of amakudari appointments in the 1990s and describe several factors underlying that trend. Pages 213-17 identify the pattern of amakudari appointment throughout the 1990s with a statistical analysis of panel data. This is followed by the conclusion.

\section{Perspectives on amakudari practices}

Although amakudari is a popular practice in Japan, it is seldom considered systematically. There are numerous arguments and discussions about it, and they can be classified into the following four perspectives: human resources, communications, monitoring, and compensation.

\section{The human resource perspective}

Utilizing valuable human resources is the reason most often mentioned in the official statements of ministers and recipient companies. For example, 
Masaru Hayami, Governor of the BOJ from 1998 to 2003, believed that amakudari executives 'are those who were recruited because their special knowledge and experience were appreciated' ${ }^{8}$ Likewise, Hakuo Yanagisawa, Minister of the Financial Sector from 2001 to 2002, implied that the recruitment of retired officials would be necessary because 'the number of those who are able to manage various practices with special financial knowledge and with strategic foresight is very limited'. ${ }^{9}$ In fact, the Japanese government has recently established a system to help private employers obtain information from retired officials. ${ }^{10}$

With regard to those officials reemployed into top executive positions, they may well be highly resourceful in some areas. After all, only a few high-ranking officials are considered for appointment to such good positions. Since internal promotion is very competitive in the government, it is not surprising that those appointed to senior positions in private firms have human capital that is highly valued by the firm.

It may be said that government retirees have considerable knowledge about relevant policies and regulations. Given that discretionary administrative guidance is often more important than legal text, it is beneficial for private companies to employ those who know the unwritten code of practice in government. Calder emphasized this aspect, arguing that ' $[t]$ he most important function of most former government officials in Japan is providing information to their adopted organizations, concerning both likely regulatory actions by their former employers and more general economic and political developments' $(1989,392)$.

However, their contribution is debatable. From his observations of the collapse of the Bubble Economy and an interview with a MOF retiree, Hartcher concluded that amakudari officials had 'no notable insights into how bank lending was contributing to the accumulation of a large speculative bubble in land and stock prices' $(1998,121)$. It should also be noted that regional banks might be biased to overestimate the resources of government officials, due to a somewhat exaggerated appreciation of the University of Tokyo, whose graduates occupy the largest share of highranking officials in the government. As a Japanese banker pointed out in an interview, 'they [regional bank executives] simply believe that MOFretired officials must have special knowledge and information to the extent that those regionally employed can never achieve, because they are the graduates of [the] University of Tokyo' (Amyx 2002, 287).

\section{The communication perspective}

While the human resource perspective tends to put more emphasis on the benefits reaped by recipient companies, the communication perspective illuminates the mutual benefit between recipient companies and home ministries. From this perspective, amakudari is often considered to be the glue reinforcing the public-private relationship in business. Johnson, for 
instance, argued that '[a]makudari provides one more channel of communication for the government, the business community, and the political world' $(1982,71)$. Wolferen $(1989,45)$ went further, saying that 'the amakudari bureaucrat surpasses any official channels in his effectiveness in maintaining the flow of information between bureaucracy and enterprises'.

For recipient companies, it is significantly less costly and more effective to communicate with the government via amakudari executives than to access the bureaucracy anonymously from the general entrance hall. Amakudari officials are often quite useful in encouraging incumbent officials to listen to their companies' voice, even if they cannot always force incumbent bureaucrats to meet their demands. From the company's point of view, it feels entitled to enjoy such special treatment in return for its salary payments to amakudari executives. For those companies, the expected benefit of communication via amakudari executives must exceed the cost of their employment.

For home ministries, incumbent government officials also seemed to enjoy communicating via amakudari executives, at least until the mid1990s. According to a 1993 survey of bureaucrats, 43 per cent believed that amakudari was beneficial because it developed the connections through which they obtained policy demands from the private sector (Nihon Keizai Shimbunsha 1994, 424). From this perspective, amakudari officials are viewed as the agent of their home ministries, acting as the terminals for information gathering. The assumption here is that they 'work' for the sake of their former employers, even though they are formally working for the private firm.

\section{The monitoring perspective}

Extending the communication perspective, the monitoring perspective assumes that amakudari executives convey information that companies would rather not reveal, playing the part of regulator. From this perspective, retired officials are most likely to be dispatched to companies with operational or financial problems. Their task is to assess the nature and degree of the problems, assist in developing solutions, and advise the home ministry as to progress in resolving the problems. To those who prefer to keep the problems secret, the use of amakudari executives seems to be better than the mobilization of incumbent officials.

The public authorities would also be inclined to utilize amakudari executives as informal regulators. While formal and direct control, e.g. nationalization, may be more effective, the government seemed to prefer such an informal approach, because they knew that 'another request for public funds could only bring greater political wrath' (Amyx 2001, 61). It should also be noted that monitoring via retired employees (or those seconded just before retirement) has been common in Japan, between 
private companies and their largest creditors, so-called 'main banks' (Aoki 1994).

While the informal monitoring through amakudari is useful in avoiding unnecessary disturbance, it may well exacerbate a problem when the government fails to solve it. Conditions may become worse, and disturbance may increase when the public learns both the extent of the problems and the fact that the government tried to solve the problems secretly. The government is reluctant to make the problem open once it has been committed, and tries to hide it. Knowing the government's reluctance, companies may well seek special secret treatment.

Amakudari may also facilitate the deterioration of company management, since company managers regard the employment of amakudari executives as 'insurance' against failure. Consistently, Horiuchi and Shimizu implied that banks tend to take more risks when they employ ex-MOF executives, with the empirical evidence being that the ratio of equity to assets is negatively correlated with the employment of ex-MOF executives (Horiuchi and Shimizu 2001). This author reaches the same conclusion with more recent data and a different set of control variables (Suzuki 2003).

It should also be remembered that amakudari executives would monitor banks as expected, because there is no compensation for good monitoring, nor sanction for negligence. In other words, their principal-agent relationship is unstable. Amakudari executives may be diligent in their mission since they are often deeply attached to their home ministries, partly because they had worked there for a long time and partly because they feel indebted to the ministries' arrangement of their reemployment. They might also be afraid of being judged to be incompetent by their former colleagues. Nevertheless, it is not surprising that they would hide information that might risk their current status, even against the interest of the government. They would understandably be reluctant to announce a problem that may cause bankruptcy, since it could mean the loss of their own income.

\section{The compensation perspective}

Amakudari is also described as a system providing incentives to government officials to work hard. While intense competition for internal promotion in the government ensures a high quality of amakudari appointees, as stated in the context of the human resource perspective, such competition is created by the expectation of reemployment into bank positions with high social status and good working conditions. As Aoki pointed out, 'the longer a bureaucrat survives in the ranking hierarchy of the ministry, the better are his/her prospects for post-bureaucrat amakudari positions'. Amakudari positions are thus considered 'the final prize in the competition among bureaucrats in the ranking hierarchy' (Aoki 1988, 266).

Those who take this perspective often mention the salary of bureaucrats, which is apparently lower than that of a typical employee in a 


\section{Kenji Suzuki}

private company. According to Ramseyer and Rosenbluth, a roughly calculated mean wage for elite national bureaucrats was JPY 318,000 in 1989, 11 per cent lower than the monthly mean national wage. They also suspect that such comparisons understate the sacrifice of those bureaucrats, since they would have earned much more than the mean national wage in private companies, being the brightest graduates from the preeminent universities (1993, 116-17). Indeed, the above-mentioned survey of bureaucrats also shows that 22 per cent of the respondents thought that amakudari was necessary because their salary was low (Nihon Keizai Shimbunsha 1994, 424). In fact, the salary of top amakudari executives was perceived to be very high due to their receipt of multiple retirement payments as a result of repeating retirement and reemployment. Such a benefit system apparently reinforces public criticism of amakudari, since the retirement benefit is a one-time-only award for most of the other workers (Tsutsumi 2000, 58-63).

Another way to explain amakudari from this perspective lies in the retirement system of government officials. Traditionally, first-class officials are identified with the year of their university graduation throughout their career, and there is a rigid custom that they should retire when their sameyear colleague becomes the vice-minister, i.e. administrative head, of a ministry, so that the colleague can hold absolute seniority within the ministry (Johnson 1995, 149-50). The vice-minister is thus expected to take care of same-year friends in return for the promotion. Since the promotion age to vice-minister is in the mid-50s, same-year colleagues also retire by that age. As a result, the average retirement age of the bureau chiefs giving way to their vice-minister colleague is around 55 (Rothatcher 1993, 173-4; National Personnel Agency 1997). Therefore, the amakudari system 'makes for a larger turnover of government officials and the injection of young blood into the system' (Blumenthal 1985, 320). In return for the early turnover, the ministry 'has the responsibility to see to it that its graduates are well cared for in their postbureaucratic life' (Prestowitz 1989, 235).

From the compensation perspective, amakudari also encourages government officials to align their interest with that of private companies '[s]ince they will one day be responsible for the regulated firm's operations, responding to opportunities for cost reductions and to changes in consumer demand' (La Croix and Mak 2001, 217). However, the alignment of public and private interests may also produce unnecessary economic rents, which may rather damage company operation (ibid., 218).

The above four perspectives are mostly complementary. In fact, amakudari is normally explained by a combination of some of those perspectives. This does not mean, however, that they are always consistent with one another. For instance, the monitoring perspective implies that government retirees are more likely to be appointed to weak firms requiring monitor- 
ing. If, however, the companies are very weak, they are less likely to offer a good salary - a fundamental part of the compensation perspective.

The expected pattern of the amakudari appointment differs across the four perspectives. From the human resource and the communication perspectives, amakudari executives may be appointed to a wide range of companies. Appointment to a limited number of weak companies is expected by the monitoring perspective. It may be true that weak companies tend to replace their executives; hence there are more chances for amakudari appointment. Yet new executives do not have to be ex-bureaucrats. When companies face red ink, they may gain more from new executives with managerial or financial expertise than from new executives with regulatory or political expertise. It may also be argued that weaker companies would be more likely to reinforce communication with the government by employing amakudari executives. However, this is the case only if amakudari executives are committed more to the regulatory process, that is, to the extent that the monitoring perspective envisages.

On the other hand, the compensation perspective implies that 'chain appointments' are likely. A chain appointment is the appointment of a retiree from a ministry at the retirement of a predecessor from the same ministry. In this way, ministries may well save the costs of seeking new positions, investigating working conditions, and negotiating with companies for amakudari acceptance.

With these theoretical perspectives on amakudari in mind, the following sections carry out empirical analysis focusing on amakudari moving into regional banks from the MOF and BOJ. Our main question concerns how the pattern of amakudari appointment through the 1990s fits those perspectives. Do any of those perspectives explain the amakudari joining regional banks in the 1990s? Was there any change during the 1990s? If so, what was it? As a first step, the next section presents a general description of the trend of the amakudari into regional banks in the 1990s, and discusses a number of factors that could potentially have transformed the system.

\section{Amakudari appointments in regional banks in the 1990s}

Firm-specific data on amakudari executives are obtained from Kigyo Keiretsu Souran through 1999 and from Yakuin Shikiho for 2000. They specify the names of the regional bank executives with work experience at public institutions. Sometimes they also specify the names of the executives with work experience at other banks. They do not provide data for all regional banks because they cover only listed companies. Since approximately 80 per cent of the regional banks are listed, the data set should be sufficient to analyze the overall phenomenon. ${ }^{11}$

Table 8.1 displays the number of amakudari appointed regional bank executives from the MOF and BOJ during the 1990s. The number of 


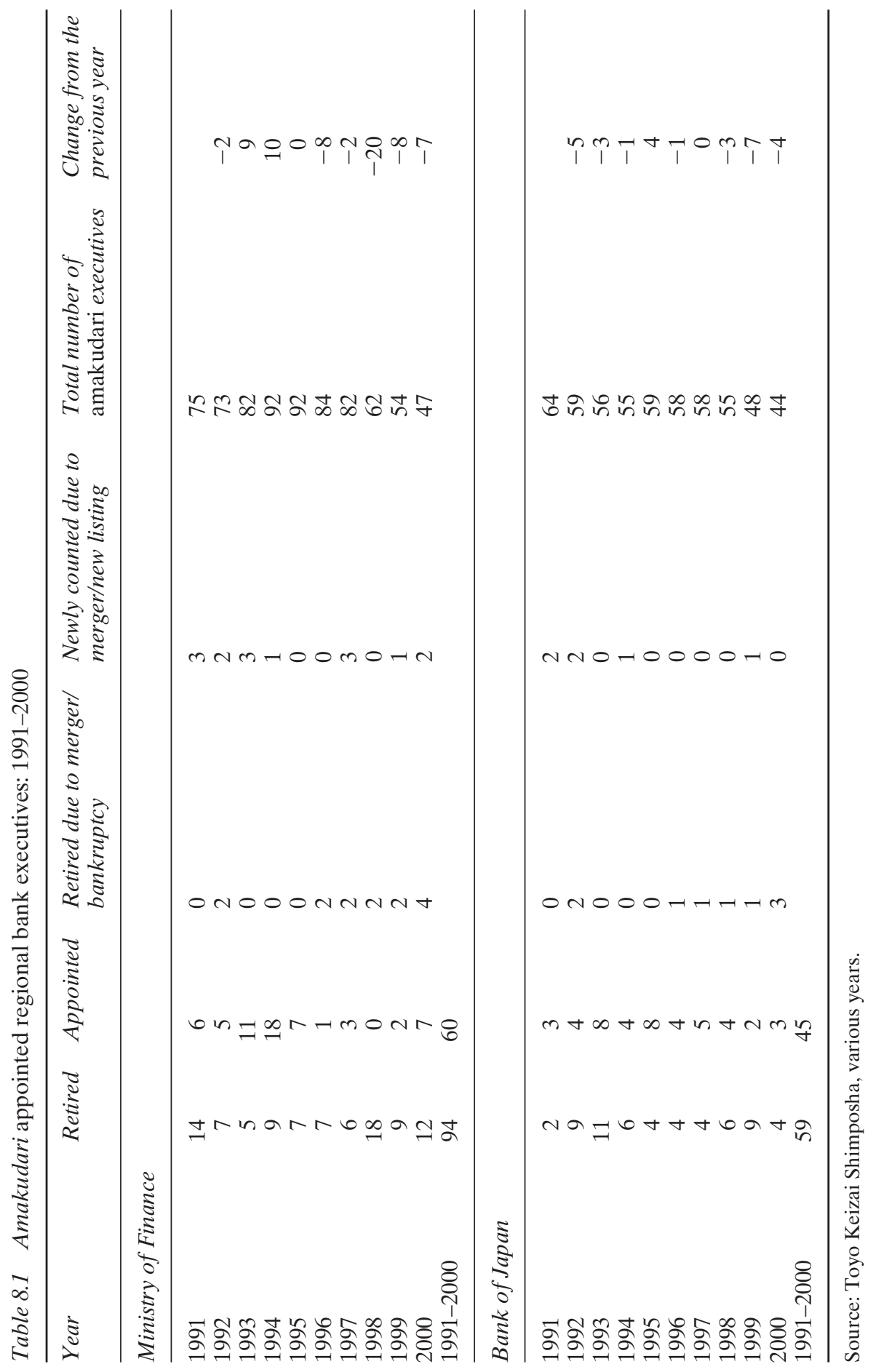


amakudari executives from the MOF generally increased in the early 1990s but decreased thereafter. There were 92 MOF amakudari executives in 1994 and only 47 in 2000. The most remarkable change occurred in 1998, when 20 ex-MOF executives left their positions (including two because of bankruptcy) but no new appointments were made.

For the amakudari from the BOJ, on the other hand, the trend was rather consistent. With the exception of $1995(+4)$ and $1997(0)$, the number of amakudari executives decreased through the 1990s. Furthermore, the degree of annual change is generally smaller than in the case of the MOF.

In order to understand those trends, it should first be remembered that the social credibility of bureaucratic management has been reduced, as noted on page 204. This was typically the case in the field of financial and monetary policy. As Cargill $(2001,151)$ noted, it turned out that ' $[t]$ he regulatory approach rooted in the old financial and monetary regime was not able to resolve the growing financial distress' in the mid-1990s. One of the key events was the bankruptcy of Hyogo Bank in 1995. The political distress caused by the financial problems of housing loan companies called jusen also impaired the social credibility of the financial authorities. One of the largest security companies, Yamaichi Shoken, went bankrupt in 1997. This was followed by the bankruptcy and nationalization of the Long-Term Credit Bank in 1998. Besides those problems, various bribery scandals and collusions between bureaucrats and banks were revealed, causing strong public emotion against bureaucrat elites.

The second factor to be noted is deregulation in the financial sector, which was partly the result of the reduction in the social credibility of bureaucratic management. The 'Big Bang' deregulation started in 1998. More significantly, the function of supervising the financial sector was transferred away from the MOF to a newly established organization, the Financial Supervisory Agency. ${ }^{12}$ Meanwhile, the BOJ seems to have reduced its authority, mainly due to the decline of national monetary policy in consequence of the development of international financial markets.

Furthermore, amakudari itself has become a target of social criticism. No matter how company leaders evaluate it, 89 per cent of middle-rank managers of private companies consider it 'unnecessary' or 'rather unnecessary' (Nihon Keizai Shimbunsha 1994, 433-44). Social criticism toward bureaucrats has grown in the course of the economic slump, as private employees recognize that public employees enjoy more employment stability than they do (such as no layoffs). Against this background, the cabinet and the Diet have been discussing amakudari for a long time. However, no remarkable change has occurred thus far, at least in the formal institutional framework.

So how do those factors explain these trends in the number of amakudari appointments? The general downward trend is well explained from the human resource perspective. The reduction in the social credibility and regulatory scope of financial officials, especially after the advent of the 


\section{Kenji Suzuki}

Financial Supervisory Agency, would devalue their human capital, and thus banks would be less willing to employ the retirees. Banks would also see a career in the public sector as rather disadvantageous in light of the severe social criticism directed towards amakudari. However, the effect of recent social and regulatory changes may be muted if retired officials are being hired primarily because they have accumulated good general skills and information about the industry over time.

The communication perspective may explain why amakudari appointments to the MOF increased in the years immediately after the collapse of the Bubble Economy. To solve their financial problems, bank managers would be inclined to increase communication with the regulatory authority. However, amakudari executives may be too costly if their function is only to facilitate communication. Banks would probably expect more than just communication, especially when suffering from financial difficulties. Therefore, the monitoring perspective may be more appropriate than the communication perspective as an explanation for the increase in amakudari appointments after the collapse of the Bubble Economy. Banks would prefer amakudari monitoring, even though it means costly employment and regulatory intervention in management. Such costly intervention may be preferred to bankruptcy.

From the communication and monitoring perspectives, the decline in the number of ex-MOF executives in the late 1990s is explained primarily by the decline of the regulatory scope of the financial authority. This is also applied to the general downward trend of amakudari appointment from the BOJ. It may not be coincidental that the number of amakudari executives from both the MOF and BOJ started to drop sharply in 1998, when the government launched the 'Big Bang' and established the Financial Supervisory Agency.

In contrast to the other three perspectives, the compensation perspective does not explain the trend by itself. After all, no remarkable change has occurred in the promotion system within the financial authorities. It was observed in the mid-1990s that '[t]here seems to be some agreement that the old promotion pattern needs to be less rigid' (Schaede 1996), but there is little evidence of any major change. Social criticism may have reduced the value of amakudari as an incentive for bureaucrats, but this does not explain the reduction of amakudari executives in regional banks. More retirees may choose to take another job or not to work, but regional banks are still attractive reemployment choices for many retirees, who would otherwise be offered less prestigious and less gainful jobs.

The current section has considered aggregate statistics. While they provide important information, our understanding can be considerably improved by analyzing variation in amakudari appointments over time and across individuals. Using multivariate analysis, the next section investigates how MOF and BOJ retirees are appointed into regional banks. 


\section{Pattern of amakudari appointment}

Corresponding to the variety of perspectives on amakudari executives, the pattern of their appointment may be considered in various ways. From the monitoring perspective, there must be a tendency that amakudari executives would be more likely to be appointed to weaker banks. From the compensation perspective, 'chain appointment', i.e. the appointment of a retiree at the retirement of a predecessor, should be more prevalent, as discussed above. From the human resource perspective, larger banks are more likely to be able to afford to employ a larger variety of executives, including ex-government officials with legal/policy expertise. The pattern may be more random from the communication perspective. While larger banks may be more able to afford amakudari employment, smaller banks would be keener to employ amakudari as a communication channel, for they would otherwise have more difficulty in direct communication with the government. From the viewpoint of the financial authorities, they would be happy to appoint their retirees to banks in various conditions, if they see amakudari only as a communication tool.

Furthermore, the appointment may be affected by the number of amakudari executives already on board, since some banks employ more than one government retiree from the MOF, BOJ or both. Many small regional banks also employ retirees from nationwide banks or large regional banks with which they have close business relationships; such appointments are often regarded as amakudari. Nonetheless, it is unclear how the appointments of the retirees from the MOF, BOJ and superior banks affect one another.

This study uses a multivariate regression model, specifically a logit model, to understand the factors underlying a bank's amakudari appointments. The logit model is chosen because the dependent variable is binary: the bank either appoints or does not appoint a government retiree to a top position at the bank. ${ }^{13}$

\section{Data}

Our panel data set includes 96 regional banks in the period between 1991 and 2000. It includes 934 observations in total. It is unbalanced, partly because several banks went bankrupt before 2000, and partly because a number of others were not listed until after 1991. During that period, there were 60 appointments from the MOF and 45 appointments from the BOJ, as shown in the last section. Only one is appointed in most of the cases, but there are four cases (Hyogo Bank in 1993, Osaka Bank in 1994, Hokuyo Bank in 1994 and Shinwa Bank in 1995) where two MOF retirees were appointed at the same time. To avoid too much complication for such a small number of cases, however, our model only considers the probability of the occurrence of amakudari appointment, regardless of the number of appointees. 


\section{Kenji Suzuki}

To put it another way, we use a logistic regression model whose dependent variable is binary. Since each bank has various characteristics that are different enough to affect the probability of its amakudari appointment, a conditional fixed-effect model is applied. The model also includes time dummy variables on the assumption that the probability of amakudari appointment varies across different years, due to such factors as deregulation of the banking sector and social criticism of MOF and BOJ bureaucrats. Therefore the model is presented as:

$$
\operatorname{Pr}\left(\mathrm{y}_{\mathrm{i}, \mathrm{t}}=1\right)=\Lambda\left(\alpha_{\mathrm{i}}+\alpha \beta^{\prime} \mathrm{X}_{\mathrm{i}, \mathrm{t}}+\delta_{\mathrm{t}}\right)
$$

$\mathrm{y}_{\mathrm{i}, \mathrm{t}}=1$ where amakudari appointment is observed at bank $\mathrm{i}_{\mathrm{i}}$ in year $\mathrm{r}_{\mathrm{t}} ; 0$ otherwise. $\alpha$ and $\delta$ denote the effect of each bank and each year respectively. $\Lambda$ is the logistic distribution function of $\Lambda(\mathrm{z})=\exp (\mathrm{z}) /[1+\exp (\mathrm{z})]$.

The explanatory variables $\left(\mathrm{X}_{\mathrm{i}, \mathrm{t}}\right)$ are classified into four categories. The first category includes variables regarding the static economic profile of banks. This includes the equity/asset ratio, the profit/asset ratio, and the asset size in year $\mathrm{t}$.

The second category relates to changes in the bank's economic profile. It consists of the changes in the three variables discussed above from year $\mathrm{t}-1$ to year $\mathrm{t}$. This category also includes a variable which proxies for changes in the economic environment within which the bank is embedded. The proxy is the change in land prices, an asset which often serves as collateral for a regional bank loan. The available data source (Todofuken Chika Chosa/The Survey on Land Prices of Prefectures) provides average prices of commercial and residential lands by prefecture, and the prices of commercial land are applied since they seem to be more influential in the management of banks than the others. Average land price data by prefecture is appropriate since regional banks typically confine their business within prefecture boundaries.

The third category concerns amakudari executives of the same origin and includes two variables: the number of those executives already on board and the number of those executives leaving the bank.

The fourth category includes the variables describing the status of other executives. In the model of MOF amakudari, this means that the variables are the number of ex-BOJ executives on board, and the numbers of new appointments from the BOJ and retirements of ex-BOJ executives. Likewise, the model of BOJ amakudari includes the corresponding numbers of ex-MOF executives as explanatory variables.

\section{Estimation and results}

The model is estimated with two different dependent variables, MOF amakudari and BOJ amakudari. Since a conditional fixed-effect Logit panel model excludes the observation groups, i.e. banks, with all positive 
or all negative outcomes (Gould 2000), the numbers of observations used for the models of MOF and BOJ amakudari are reduced to 378 and 361 respectively. With regard to the explanatory variables, no serious multicollinearity is observed. ${ }^{14}$

Table 8.2 shows the estimated coefficients on the explanatory variables for the models. In both models, the significance of the overall model is sufficient, according to the diagnosis using Likelihood Ratio (LR) chi-square statistics.

With regard to MOF amakudari, statistically significant variables include profit-asset ratio, asset size, change of equity-asset ratio, change of profit-asset ratio, the number of other ex-MOF executives on board, and the number of new appointments of BOJ retirees. The contribution of the first two variables and the last variable is positive, while the others contribute negatively.

The negative contribution of the dynamic financial status (change of equity-asset ratio and change of profit-asset ratio) may imply that banks were more likely to employ MOF retirees when their financial conditions deteriorated. This is consistent with the human resource, communication, and monitoring perspectives, which may suggest that banks would prefer either to enrich their human resources, to improve their communication with the authority, or to ask the authority for help, when they face financial difficulties.

On the other hand, the positive contributions of profit-asset ratio and asset size means that MOF retirees were more likely to be appointed to more profitable and bigger banks, which may fit the compensation perspective. In other words, amakudari appointment seems to occur not just when banks are motivated, but also when it is attractive from the viewpoint of the retirees.

Amakudari appointments are, however, negatively correlated with the number of incumbent ex-MOF executives. This seems to reflect the fact that many banks have a fixed number of executive positions specifically allocated for MOF retirees. Yet it should also be remembered that our result does not show a statistically significant contribution of the retirement of incumbent amakudari executives. This means that 'chain appointments' are not a significant determinate of amakudari.

The appointment from the MOF is also correlated with the appointment from the BOJ, although its statistical significance is rather weak. From this, it might follow that the BOJ's amakudari appointment occurs in the same manner as that of the MOF. Nevertheless, our result of the estimation of BOJ amakudari marks a somewhat different pattern of correlations.

The positive contribution of the equity-asset ratio may indicate that $\mathrm{BOJ}$ retirees tend to be appointed to more stable banks. This is analogous to the case of the MOF, whose retirees are more likely to be appointed to more profitable and bigger banks. However, it is not clear why the MOF and $\mathrm{BOJ}$ are associated with different static variables. On the other hand, 


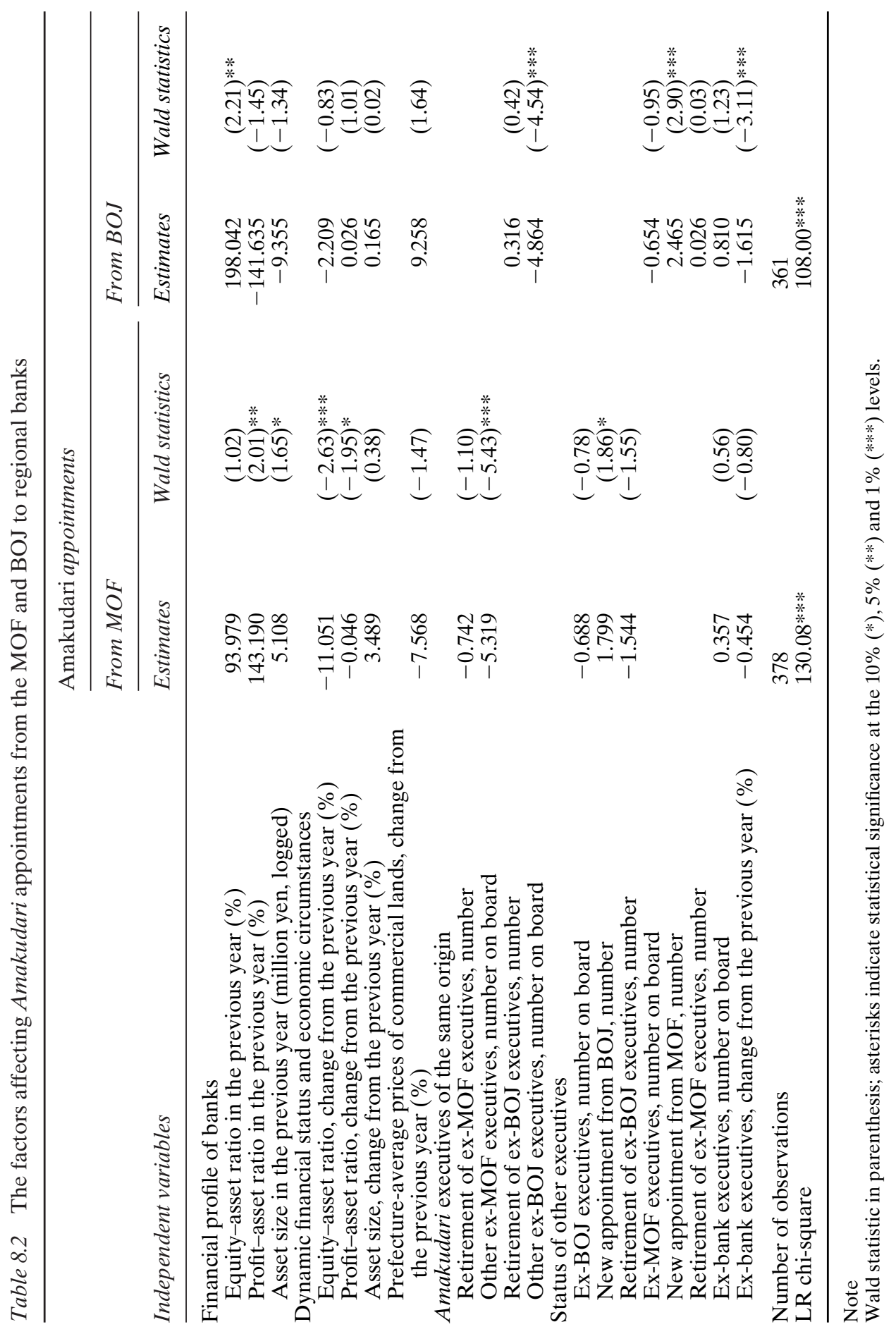


none of the variables regarding dynamic financial status and economic environment are statistically significant. Furthermore, the negative correlation with the change in the number of ex-bank executives is specific to the case of BOJ amakudari, while the negative correlation with the number of incumbent ex-officials on board is just the same as in the case of MOF amakudari. This implies that banks often treat BOJ retirees as an alternative to the retirees from other banks.

\section{Conclusion}

Amakudari is well known in Japan, but the literature on the Japanese political economy has seldom examined it systematically. Moreover, it is often assumed to be a system that never changes. This assumption is apparently convincing particularly in the case of regional banks, where many incumbent amakudari executives and even new appointments are still observed despite the shrinking scope of regulation and growth in public scepticism about bureaucratic control. Nonetheless, we should recall the observation shared by the scholars of institutionalism that institutions themselves may be resistant to change, but their impact on political outcomes can change over time in subtle ways in response to shifts in the broader socio-economic or political context' (Thelen and Steinmo 1992, 18).

The change in the pattern of amakudari appointments seems to be consistent with that observation. While 'chain appointments' were considered to be important prior to the 1990s (see Horiuchi and Shimizu 2001, for example), the logit results show that they were not important in the 1990s. On the other hand, the fact that appointment is more likely to occur at profitable and big banks in the case of MOF amakudari and at stable banks in the case of BOJ amakudari partially justifies a traditional view that "retiring bureaucrats would "descend from heaven" to take high-level, high-paying jobs' (Pempel 1998, 95).

It is not clear how the amakudari system will change in the future, in consequence of such socio-economic changes as further deregulation and financial globalization. In April 2003, the Japanese government launched a reform of the promotion system of government officials to restrict the amakudari practice. To discuss the result of this effort is left to further studies. The key question for policymakers is not the precise identification of the reason for the fall in amakudari numbers but rather how the incentives to make such appointments have changed over time. The theoretical framework and the empirical observations presented in this study may be useful in addressing that question.

\section{Notes}

1 For instance, Pempel $(1998,95)$ clearly identified amakudari as an 'institution'.

2 However, some define amakudari in broader terms. For example, Colignon and 


\section{Kenji Suzuki}

Usui (2001) argue that the concept should also include the movement of retired officials into other public organizations and political life. Tsutsumi (2000) treats any type of bureaucratic reemployment as amakudari, including academic positions at universities.

3 However, this source also shows that the number of amakudari officials sitting in executive positions increased from 993 to 1,061 in the same period, although with the share of amakudari executives in the total number of executive positions falling slightly (from 2.74 per cent to 2.66 per cent).

4 Precisely speaking, regional banks are classified into two groups: 'first-tier regional banks' and 'second-tier regional banks'. The latter group is smaller, and its members were converted into regular banks only in the late 1980s. There is not much difference in their functions, despite the formal classification. This study does not distinguish between them, but identifies them with the generic concept of 'regional banks'.

5 See, for example, Suzuki (2002) for the case of the Fair Trade Commission.

6 The BOJ's monetary policies clearly affect business decisions at regional banks; information about the details of monetary policy may be valuable to commercial banks, and information about the health of regional banks may also be useful to the BOJ in setting monetary policy.

7 The other 8 per cent of deposits belong to eight trust banks and a long-term trust bank. Postal savings, credit associations, and other financial companies are excluded.

8 House of Representatives, the 155th Session, Budget and Finance Committee, Vol. 1, 29 October 2002.

9 House of Representatives, the 151st Session, Budget and Finance Committee, Vol. 13, 31 May 2001.

10 See National Personnel Agency (2001), chapter 10, for details.

11 It should be noted that amakudari are allegedly more likely to be appointed to non-listed banks and other smaller financial institutions with less public managerial roles. If this allegation is correct, then our data set underestimates the likelihood of amakudari appointment.

12 The Financial Supervisory Agency was renamed the Financial Services Agency after its reorganization in July 2000.

13 For logistic regression, see DeMaris (1992), for example.

14 For instance, the highest value of the variance inflation factor (VIF), which is often used for the diagnosis of multicollinearity, is 3.45 in the MOF model, and 3.59 in the BOJ model. In general, a VIF in excess of 10 is an indication of serious multicollinearity. See, for example, Neter et al. (1985).

\section{Bibliography}

Amyx, Jennifer A. (2001) 'Informality and Institutional Inertia: the Case of Japanese Financial Regulation', Japanese Journal of Political Science, Vol. 2, No. 1, pp. 47-66.

- (2002) 'Okurasho Nettowaku - Kenryokuno Kakudaito Seiyakuno Kiketsu (Ministry of Finance Network - The Result of Power Expansion and Restriction', in Muramatsu, Mikio and Okuno, Masahiro (eds) Heisei Baburuno Kenkyu, Ge [Study on Heisei Bubble, Volume II], Tokyo: Toyo Keizai Shimposha, pp. 273-96.

Aoki, Masahiko (1988) Information, Incentives, and Bargaining in the Japanese Economy, Cambridge: Cambridge University Press.

- (1994) 'Monitoring Characteristics of the Main Bank System: An Analytical and Developmental View', in Aoki, Masahiko and Patrick, Hugh T. (eds) The 
Japanese Main Bank System: Its Relevance for Developing and Transforming Economies, Oxford: Clarendon Press, pp. 109-41.

Blumenthal, Tuvia (1985) 'The Practice of Amakudari within the Japanese Employment System', Asian Survey, Vol. 25, No. 3, pp. 310-21.

Calder, Kent (1989) 'Elites in an Equalizing Role: Ex-bureaucrats as Coordinators and Intermediaries in the Japanese Government-Business Relationship', Comparative Politics, Vol. 21, Iss. 4, pp. 379-403.

Cargill, Thomas F. (2001) 'Central Banking, Financial, and Regulatory Change in Japan', in Blomström, Magnus, Gangnes, Byron and La Croix, Sumner (eds) Japan's New Economy: Continuity and Change in the Twenty-first Century, New York: Oxford University Press, pp. 145-61.

Colignon, Richard and Usui, Chikako (2001) 'The Resilience of Japan's Iron Triangle', Asian Survey, Vol. 41, No. 5, pp. 865-95.

DeMaris, Alfred (1992) Logit Modeling: Practical Applications, Newbury Park: Sage Publications.

Gould, William (2000) 'Interpreting Logistic Regression in all its Forms', STATA Technical Bulletin, STB-53, January 2003, pp. 23-9.

Hartcher, Peter (1998) The Ministry: The Inside Story of Japan's Ministry of Finance, London: HarperCollins Business.

Horiuchi, Akiyoshi and Shimizu, Katsutoshi (2001) 'Did Amakudari Undermine the Effectiveness of Regulator Monitoring in Japan?' Journal of Banking and Finance, Vol. 25, No. 3, pp. 573-96.

Ikuta, Tadahide (1995) Kanryo, Japan's Hidden Government, New York: NHK Publishing.

Japanese Bankers Association (2002) Zenkoku Yokin Kashidashikin Sokuho [National Deposit/Loan Bulletin]. Online. Available at: www.zenginkyo.or.jp/ stat/index.html. Accessed 20 December 2002.

Johnson, Chalmers A. (1982) MITI and the Japanese Miracle: The Growth of Industrial Policy, 1925-1975, Stanford: Stanford University Press.

- (1995) Japan: Who Governs? the Rise of the Developmental State, New York: W.W. Norton \& Company.

La Croix, Sumner and Mak, James (2001) 'Regulatory Reform in Japan: The Road Ahead', in Blomström, Magnus, Gangnes, Byron and La Croix, Sumner (eds) Japan's New Economy: Continuity and Change in the Twenty-first Century, New York: Oxford University Press, pp. 215-41.

Ministry of Land, Infrastructure and Transport, Todofuken Chika Chosa [The Survey on Land Prices of Prefectures], Tokyo: Ministry of Land, Infrastructure and Transport.

National Personnel Agency (1997) Annual Report 1996, Tokyo: National Personnel Agency. Online. Available at: www.jinji.go.jp/hakusho/h08/h8f.htm (in Japanese). Accessed December 20, 2002.

— (2001) Annual Report 2000, Tokyo: National Personnel Agency. Online. Available at: www.jinji.go.jp/english/annnal2000/index.htm (in English). Accessed 20 December 2002.

Neter, John, Wasserman, William and Kutner, Michael H. (1985) Applied Linear Statistical Models: Regression, Analysis of Variance, and Experimental Designs, Homewood, IL: R.D. Irwin.

Nihon Keizai Shimbunsha (ed.) (1994) Kanryo - Kishimu Kyodai Kenryoku [Bureaucrats - Creaking Great Power], Tokyo: Nihon Keizai Shimbunsha. 


\section{Kenji Suzuki}

Okimoto, Daniel I. (1988) 'Political Inclusivity: The Domestic Structure of Trade', in Inoguchi, Takashi and Okimoto, Daniel I. (eds) The Political Economy of Japan Volume 2: The Changing International Context, Stanford, CA: Stanford University Press.

Pempel, T. J. (1998) Regime Shift: Comparative Dynamics of the Japanese Political Economy, Ithaca, NY: Cornell University Press.

Prestowitz, Clyde V., Jr. (1989) Trading Places: How We Are Giving Our Future to Japan and How to Reclaim It, New York and London: Basic Books.

Ramseyer, J. Mark and Rosenbluth, Frances McCall (1993) Japan's Political Marketplace, Cambridge, MA: Harvard University Press.

Rixtel, Adrian A. R. J. van and Hassink, Wolter H. J. (1998) 'Monitoring the Monitors: Amakudari and the Ex-post Monitoring of Private Banks', Discussion Paper No. 1785, January 1998, London: Centre for Economic Policy Research.

Rothacher, Albrecht (1993) The Japanese Power Elite, Basingstoke: Macmillan.

Schaede, Ulrike (1996) 'The Ministry of Finance, Change, and Sherlock Holmes', Social Science Japan, No. 7, August 1996. Online. Available at: web.iss.utokyo.ac.jp/newslet/SSJ7/Schaede.html. Accessed 20 December 2002.

Suzuki, Kenji (2002) Competition Law Reform in Britain and Japan: Comparative Analysis of Policy Networks, New York: Routledge.

- (2003) 'The Effect of Amakudari on Bank Performance in the Post-bubble Period', in Park, Sung-Jo and Horn, Sierk (eds) Asia and Europe in the New Global System, London: Palgrave Macmillan, pp. 51-65.

Thelen, Kathleen and Steinmo, Sven (1992) 'Historical Institutionalism in Comparative Politics', in Steinmo, Sven, Thelen, Kathleen and Longstreth, Frank (eds) Structuring Politics: Historical Institutionalism in Comparative Analysis, Cambridge: Cambridge University Press, pp. 1-32.

Toyo Keizai Shimposha, Kigyo Keiretsu Soran [The Comprehensive List of Corporate Keiretsu], Tokyo: Toyo Keizai Shimposha. - (2001) Yakuin Shikiho [Seasonal Report on Corporate Executives] 2001, Tokyo: Toyo Keizai Shimposha.

Tsutsumi, Kazuma (2000) Kyodaishouchou Amakudari Fuhai Hakusho [White Paper on Amakudari Corruption of Giant Ministries], Tokyo: Kodansha.

Wolferen, Karel van (1989) The Enigma of Japanese Power: People and Politics in a Stateless Nation, London: Macmillan. 


\title{
9 Divorce in Japan Why it happens, why it doesn't
}

\author{
Hiroshi Ono
}

\section{Introduction}

The rising divorce rate is a universal feature among industrialized societies, and a natural consequence of economic development and social change. The pursuit of greater equality between the sexes, the availability of alternative arrangements to marriage, and the increasing role of the government in providing welfare for families offset the costs and benefits of marriage. Macro-level changes that affect the economic activities of the society may influence the actions of individuals at the micro-level through the strengthening or weakening of social norms, social relationships, and cultural attributes.

This chapter examines the changes in the patterns of marriage and divorce in contemporary Japanese society. In 2003, the divorce rate in Japan reached an all-time high for the postwar period. There are no signs that the divorce rate will decline in the foreseeable future. This social trend seems incongruous with the behavior of the Japanese who have traditionally valued harmony, loyalty, and long-term commitments. Paralleling the decline of lifetime employment in Japan, the media, in particular the Western media, are quick to point out that the rising divorce rate symbolizes a cultural shift, and the demise of traditional values. But the increasing patterns of marital disruption is a universal phenomenon among the industrialized societies, and certainly not unique to Japan. What is more surprising and often overlooked is the fact that the divorce rate in Japan still remains low among the industrialized economies.

A better understanding of marriage and divorce in Japan therefore requires separating the two questions: why is the divorce rate in Japan low by international standards? And, why is it rising?

Studying the changing patterns of marriage is a study of institutional change. It cannot be done in isolation but, rather, requires a thorough examination of its complementary institutions, and their influence on individual actions. In this chapter, we first briefly examine the background factors governing gender relationships in postwar Japan. We then discuss why divorce happens, and why it doesn't, in contemporary Japan. 


\section{Hiroshi Ono}

\section{Economic development and the gendered division of labor in postwar Japan}

Economic development in postwar Japan was achieved under the implicit assumption that the traditional division of labor between the sexes was the optimal condition for growth. The practice of lifetime employment which flourished in the postwar period strongly favored men over women. The extensive training, generous benefits and internal promotion that characterized the internal labor market in Japan were only available to workers who were able to make long-term commitments. Women, who were expected to make commitments to their families, were effectively excluded from taking up positions in the internal labor market. Women's employment opportunities were thus mainly restricted to the secondary labor market characterized by dead-end jobs, or short-term temporary jobs, and their contribution to the household finances was strictly secondary to their husbands.

Lifetime employment therefore reinforced the specialization between the sexes. Since the desirable jobs were unavailable for most women, their incentive to invest in human capital was low. Specialization in non-market work in turn decreased their prospects for re-employment. Men, on the other hand, were able to devote their lives entirely to market work. Employers became increasingly more reliant and expected nothing less than workers' complete dedication to their work. Moreover, employers expected their wives to support this complete specialization between the husbands and wives. In his in-depth study of the lives of working men in a Japanese bank, Rohlen explained:

The family recognized by the bank is a nuclear family with the wife and children dependent on the husband-father, who serves as its link with the bank and the outside world. The family is, thus, a dependency of [the bank] and this view reinforces the principle of a strict division of labor between husband and wife. Properly the wife cares for the children and creates a stable and supportive home environment. The bank would strongly discourage any wife from working, for this would take her from her primary roles of mother and wife.

(1974: 242)

The employment relationship rested on an implicit contract where workers put in long hours and made long-term commitments in exchange for employment security and compensation based on length of service with the employer (the so-called seniority wage system). Workers assessed with reasonable trust and certainty that they could depend on long-term employment and automatic wage growth. Employment and income security therefore made it easier for the worker and his family to predict their economic well-being in the future as long as he remained with the firm. 
While Rohlen suggests that employers discouraged wives from working, another interpretation is that employers provided employment and income security so that the wives did not have to work. ${ }^{1}$

The promotion of "good wife, wise mother" (ryosai kenbo) reinforced, if not encouraged, the specialization between the sexes throughout much of the twentieth century. The slogan traces its origin to the aftermath of the Sino-Japanese War (1894-5), when officials in the Ministry of Education began to promote women's proper role in imperial Japan as "managers of domestic affairs in households and nurturers of children" (Uno 1993: 294). As Uno explained:

Although overt attempts by the state to dictate womanhood have decreased in intensity since 1945 , a transmuted vision of women that often emphasized their difference from men as homebound wives and mothers continued to influence state policies toward welfare, education, employment, sexuality, and reproduction at least until the late 1980s.

(1993: 294-5)

According to Ochiai (1997), "in the postwar period, the state of being a housewife became so strongly normative that it was practically synonymous with womanhood" (p. 35).

A notable example of public and private initiatives to influence the management of domestic affairs was the New Life Movement, a set of loosely connected initiatives of government ministries, women's organizations, and corporations that started in the late 1940s (Gordon 1997). ${ }^{2}$ The Movement was targeted not at men but their wives, and resembled something of a "social education." Companies organized family support groups and designated full-time "family organizers" with the aim of educating wives about the importance of sex roles, reproduction, and the definition of "housewife." The wives in turn came to believe that active participation in the New Life Movement would help their husbands to advance at work. As Gordon (1998) explained, a number of corporations in the U.S. and Germany offered social services to employee wives in the postwar period, but none were as extensive and sustained as those of Japan's major corporations: "Nowhere else did the business community with state encouragement organize a national campaign to orchestrate training for over one million wives of male industrial workers" (1998: 78).

Tax and benefit programs introduced in the postwar period were legislated assuming the male breadwinner model, i.e. a family comprised of a working husband and a non-working wife. ${ }^{3}$ For example, Japan's tax and pension system discourages wives from earning more than 1.3 million yen per year to avoid paying taxes and pension contributions. The current system - sometimes referred to as "policies to protect the well-being of housewives" (Higuchi 1995) - was originally designed to protect married 


\section{Hiroshi Ono}

women from declines in household income when they moved from market to household work. However, despite its intentions, the underlying assumption of non-working wives (or wives as secondary earners) encourages wives to engage in low-paying jobs, and makes them more dependent on their husbands. The weak economic position of wives makes them extremely vulnerable in the event of a divorce.

\section{Divorce in postwar Japan}

Between 1980 and 2003, the divorce rate among married couples in Japan increased from 18.3 percent to 33.1 percent. And yet, despite its recent increase, the Japanese divorce rate remains low by international standards (Table 9.1). The first column of Table 9.1 shows the divorce rate per 100 married couples in selected countries. The data can be interpreted as the probability that the marriage will result in divorce. ${ }^{4}$

Despite significant advances in women's economic positions in the postwar period, Japanese women nonetheless maintained traditional views of marriage and the gender division of labor. Table 9.2 shows the results of the International Comparative Survey Concerning Issues Confronting Women conducted by the Tokyo Metropolitan Government in 1993. ${ }^{5}$ Women in Japan were less likely to agree to divorce, and were more likely to view marriage as the ultimate form of happiness, show support for the male breadwinner model, and raise children according to their gender roles. Attitudinal surveys taken over time show that both men and women in Japan have become more tolerant of divorce over the last 25 years, but still remain less tolerant than their Western counterparts. ${ }^{6}$ The survey results suggest that the legacy of "good wife, wise mother" and the gendered division of labor continue to affect the behavior and attitudes of Japanese women today.

Examining data across various countries illuminates many of the unique features underlying marriage and divorce in Japan. We discuss below some of the reasons why the divorce rate in Japan is low compared to other industrialized economies, and why it is becoming more frequent in recent years.

\section{Social norms}

The low divorce rate in Japan may be an outcome of the social norms and expectations that influence the transitions in women's life course in Japan. For example, Brinton (1992) explained how Japanese women face normative expectations to marry "on schedule." Using an analogy to Christmas cakes, women who are not married by the age of 25 become, like Christmas cakes, undesirable "leftover goods," that is, their value in the marriage market declines considerably. Moreover, life-course transitions must proceed in sequence, progressing from school to work, then marriage and 
Divorce in Japan

Table 9.1 Divorce, marriage and family statistics among selected countries

\begin{tabular}{llccc}
\hline & $\begin{array}{l}\text { Divorce per 100 } \\
\text { married couples }\end{array}$ & $\begin{array}{l}\text { One parent } \\
\text { families }^{2}\end{array}$ & $\begin{array}{l}\text { Out of wedlock } \\
\text { children }^{2}\end{array}$ & $\begin{array}{c}\text { Working } \\
\text { mothers }\end{array}$ \\
\hline Japan & 33.1 & 4 & 1.1 & 33.7 \\
U.S. & 50.6 & 25 & 25.0 & 61.2 \\
Belgium & 59.8 & 13 & 11.0 & 66.2 \\
Sweden & 53.9 & 19 & 47.0 & 76.1 \\
Finland & 53.2 & - & - & 58.8 \\
U.K. & 52.7 & 19 & 30.0 & 55.5 \\
Austria & 49.8 & - & - & 66.0 \\
Luxembourg & 48.0 & 10 & 12.9 & 56.8 \\
Germany & 44.3 & 12 & 15.5 & 52.8 \\
France & 40.9 & 13 & 28.4 & 58.6 \\
Norway & 39.7 & 19 & 40.9 & 72.8 \\
Netherlands & 39.3 & 10 & 11.4 & 66.4 \\
Denmark & 37.5 & 18 & 46.0 & 64.3 \\
Portugal & 30.0 & 6 & 14.7 & 43.3 \\
Spain & 16.5 & 5 & 10.0 & 46.6 \\
Greece & 15.4 & 5 & 2.0 & 46.9 \\
Italy & 12.5 & 7 & 6.3 & \\
\hline
\end{tabular}

Sources: (1) Organization for Economic Cooperation and Development (2003); (2) Whiteford and Bradshaw (1994).

Note

* Working mothers defined as the proportion of mothers with children under six years old in the labor force.

Table 9.2 Views on marriage and family among selected countries (women only)

\begin{tabular}{|c|c|c|c|c|c|c|}
\hline & Japan & U.S. & U.K. & France & Germany & Sweden \\
\hline $\begin{array}{l}\text { If and when one cannot find } \\
\text { satisfaction with a mate, it } \\
\text { is better to get a divorce }\end{array}$ & 44.6 & 69.9 & 82.8 & 83.1 & 80.9 & 65.3 \\
\hline $\begin{array}{l}\text { All things considered, women's } \\
\text { happiness lies in marriage, } \\
\text { so it's better for women }\end{array}$ & & & & & & \\
\hline to marry & 66.1 & 79.9 & 87.5 & 66.4 & 57.9 & 76.7 \\
\hline $\begin{array}{l}\text { The husband should be the } \\
\text { breadwinner, and the wife } \\
\text { should stay at home }\end{array}$ & 55.6 & 23.7 & 20.3 & 22.4 & 24.8 & 12.8 \\
\hline $\begin{array}{l}\text { To teach a boy to behave like } \\
\text { a boy and a girl to behave } \\
\text { like a girl }\end{array}$ & 45.6 & 28.2 & 15.8 & 24.1 & 14.8 & 6.3 \\
\hline
\end{tabular}

Source: Tokyo Metropolitan Government 1994. 
parenting, and this process is irreversible. Comparing data from the U.S.A. and Japan, she found that the timing of life-course transitions such as schooling, marriage, and work was less diverse in Japan than in the United States: Japanese women complete school, get married, and exit the labor force with remarkably similar timing, and there is little deviation from the mean.

Low variance and irreversibility may explain the low divorce rate and the conformity in the timing of marriage and family formation in Japan. One-parent families and out-of-wedlock children, for example, are very rare (Table 9.1). Cohabitation, although widespread in other countries, is virtually non-existent. In 1999, the cohabitation rate among females in the age group 20 to 24 was only 2.3 percent in Japan, compared to 77 percent in Sweden and 63 percent in France (National Institute of Population and Social Security Research 1999; United Nations 2000).

Hence, the divorce rate might be higher in Japan if marriage were to be regarded as more reversible. On the other hand, the divorce rate in Japan might be even lower if cohabitation or other forms of family formation were to become more acceptable as an alternative to marriage.

While irreversibility may restrain some couples from getting divorced, it may also restrain others from getting married. Tsuya et al. (2004) hypothesize that the price of marital stability in Japan may be the increasing reluctance of young women to enter into marriage, and that this partly explains recent patterns of delayed marriages in Japan. ${ }^{7}$

\section{The stigma of divorce}

Divorce may be more stigmatized in Japan because of the greater importance of extended family and kinship ties in marriage. As exemplified by the expression, "when you get married, you get married for the people around you" (Brinton 1993: 99), marriage in Japan has been based less on personal preferences, and more on the wishes of the (extended) families and kin. Compatibility between the families plays an important role in marriages, especially if they are arranged. In the event of difficulties confronted in marriage, it is common for a woman to seek approval from her family before she decides to divorce (Vogel 1991).

The higher prevalence of arranged marriages and the strength of intergenerational ties suggest that marriage in Japan is "a more rigid social institution involving the interests of and influences from the extended family and kinship ... [in contrast to marriage in the U.S.A. which is] primarily a matter of individual choice for the happiness and well-being of couples and their children" (Bumpass and Choe 2004: 20). The stigma attached to divorce is therefore likely to be greater in Japan, because divorce is not just a private affair - a break-up of the couples - but a break-up involving the extended families. ${ }^{8}$

Numerous studies have documented the extraordinary measures taken 


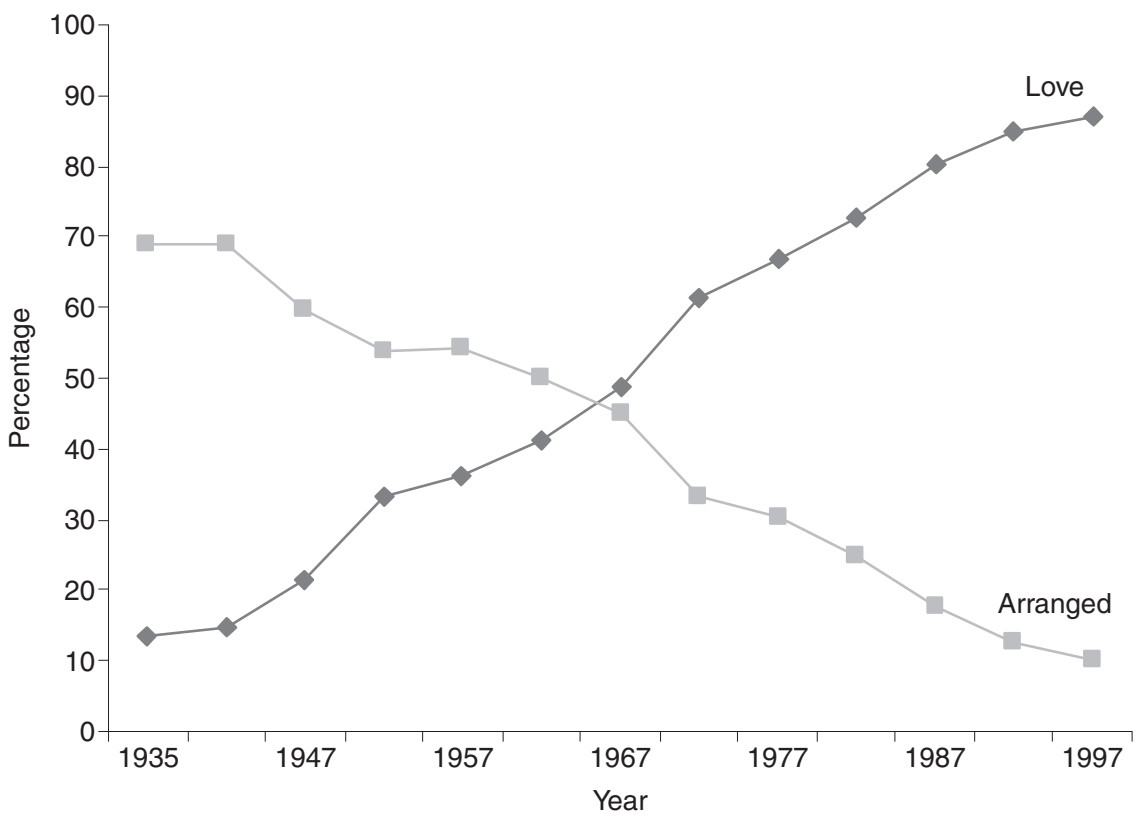

Figure 9.1 Types of marriages in Japan (source: National Institute of Population and Social Security Research 1997).

Note

The sum of "love" and "arranged marriages" does not add up to 100 because of the small percentage of persons in the "other" category).

by Japanese couples whose marriages have deteriorated, but who remain together to avoid the stigma of divorce, either for themselves, or for the sake of their children. For example, Yamashita (1986) described a case of a "nondivorce divorce" where one couple who had been married for 15 years was barely on speaking terms, but the husband would not grant divorce, claiming it was disgraceful. Similarly, Iwao (1993) used the expression "divorce within the home," and described one woman who planned her divorce for over ten years, waiting for the right time, in her case for the children to marry and move out of the household. ${ }^{9}$

While the relationship between arranged marriages and divorce has not been well established, it is conceivable that the recent increase in divorce rates is linked to the decline in arranged marriages during the same period (see Figure 9.1). Arranged marriage was the norm for much of the postwar period, and it is only in recent years that the proportion of arranged marriages has been overtaken by the proportion of marriages out of love. The stigma of divorce is conceivably weaker if the marriage evolved out of love because the ties between the extended families are weaker, and the couple need not be concerned with disgracing the reputation of the intermediary. 


\section{Hiroshi Ono}

As Iwao explained, "divorce is now easier because it is considered a private (i.e., between the couple themselves), rather than a family (in the sense of the extended family) matter" (1993: 119), and couples feel less inclined to "keep up appearances." She concluded by explaining that the divorce rate in Japan will rise gradually as the social sanctions and obstacles against divorce are lifted.

\section{Economic dependency}

Women's economic dependency in marriage is a crucial determinant of divorce in contemporary societies. Economic independence is determined by earnings power, and influences each spouse's ability to walk away from marriage. Using the analogy of Hirschman's "exit, voice and loyalty," Hobson (1990) explains that women with low earnings potential have a weaker voice and fewer exit possibilities. The greater likelihood of divorce in contemporary societies is the outcome of the decline in loyalty between spouses, and women's lower economic dependency which have lowered the costs of exiting marriages.

Specialization within the household limits women's opportunities in the labor market and makes them financially vulnerable in the event of a divorce. As Oppenheimer explains, "extreme sex-role specialization in marriage is essentially a high-risk and inflexible family strategy unless accompanied by supplementary support mechanisms" (1997: 447). In this regard, marriage is similar to an implicit long-term contract that protects women from their husbands against abandonment and other adversities (Becker 1993). Advances in women's educational attainment and laborforce participation increase their earnings capacity, reduce the advantages of the sexual division of labor-in marriage, and make women less dependent on their husbands. Women with higher earnings are therefore more prone to divorce, and this pattern is consistent with the evidence from other countries. ${ }^{10}$

The costs and benefits of marriage are determined by the nature of investments undertaken in marriage. England and Kilbourne (1990) distinguish between general and relation-specific investments; general investments comprise education and other investments in human capital that will benefit the marriage but are not specific to the marriage. In contrast, relation-specific investments such as the socialization of children and forming emotional attachments to in-laws are not portable or transferable outside of the marriage. In general, women make a greater number of relation-specific investments and fewer general investments than men. This asymmetry contributes to women's higher dependency on their husbands, and weakens their ability to walk away from marriage (England and Kilbourne 1990).

Mainly as the result of specialization between the sexes, Japanese women still remain highly dependent on their husbands. Women's 


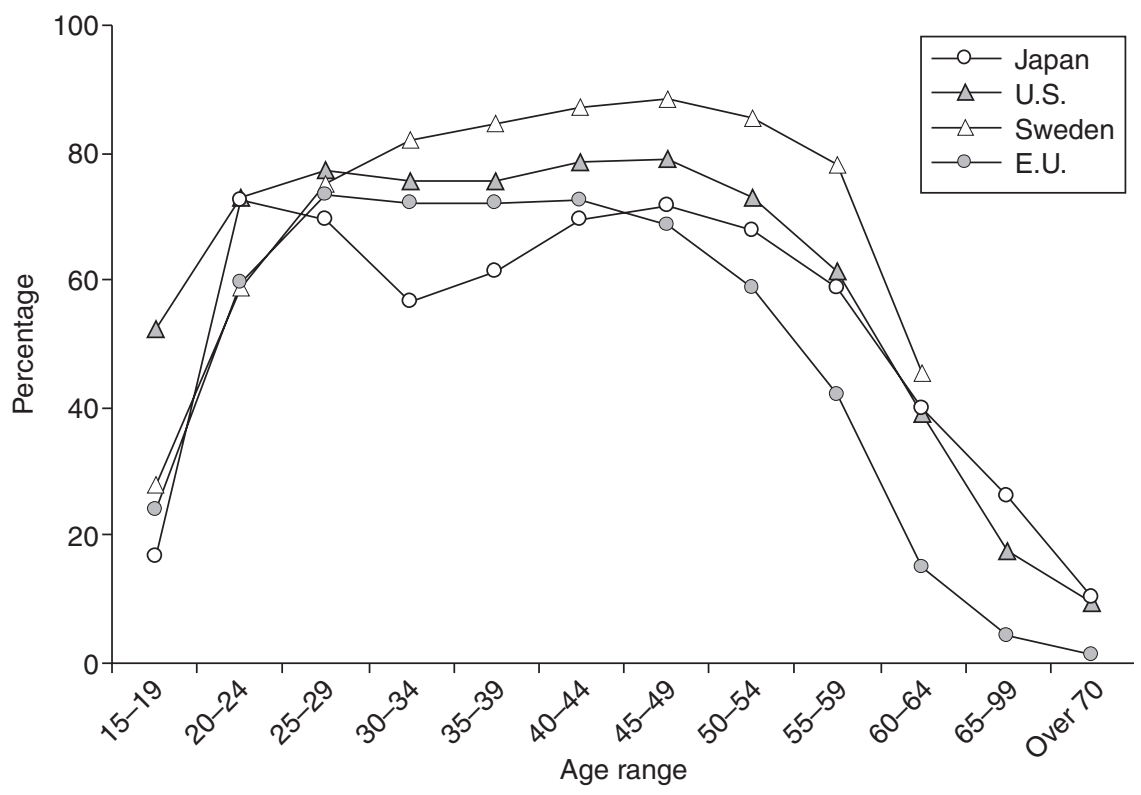

Figure 9.2 Women's labor force participation rates in selected countries (source: ILO Yearbook of Labor Statistics, selected years (1997-99)).

economic positions are still vastly inferior to men's, as indicated by various international comparisons that consistently rank Japan low on gender equality indicators. ${ }^{11}$ In comparison to the United States and Europe, married women in Japan make fewer general investments because they are assumed to be secondary earners, and they make a greater number of relation-specific investments because the importance of maintaining relationships between the extended families is primarily the responsibility of wives.

A notable example of gender inequality in Japan concerns the labor force participation of women over their lifecycle. Low variance and agecongruity that characterize lifecourse transitions in Japan lead to remarkably similar patterns in the timing of women's entry and exit from the labor force. The three key transitions - entry into the labor force after schooling, exit upon marriage or childbearing, and re-entry upon completion of some family responsibilities - progress in sequence and on schedule over the lifecourse, and result in the so-called M-curve of women's labor force participation over their lifecycle (Figure 9.2).

In particular, the massive exit from the labor force upon childbearing is one of the most pronounced in the industrialized economies, and leads to an acute drop in labor-force participation among women in the 30-39 age 


\section{Hiroshi Ono}

group. As shown in Table 9.1, the proportion of working mothers (defined as the share of mothers with children under six years in the labor force) was only 34 percent in Japan, which is the lowest among the countries reported here. In other words, as late as 1999, two out of three mothers in Japan were fully specialized in the household, and were fully dependent on their husbands for family earnings. Women's high economic dependency on their husbands makes them financially vulnerable in the event of divorce, and this is one of the strongest deterrents of divorce in Japan.

In the postwar period, the proportion of women advancing to university education in Japan increased gradually, and the gender gap in educational attainment and wages has narrowed. Women are better endowed with general human capital and are therefore less dependent on their husbands. The cost of exiting marriage is now lower, which may explain the greater likelihood of divorce in recent years.

The rise in the divorce rate in the 1990s coincides with the widely publicized view of the demise of lifetime employment. ${ }^{12}$ The economic stagnation of the 1990s and threats of restructuring and downsizing may have compelled some housewives to reconsider their total dependency on their husbands. The percentage of mothers who continue working after having children, and the percentage of working women in the 30-39 age group, grew steadily throughout the 1990s, leading to the flattening out of the Mcurve distribution of women's labor force participation (Japan Institute of Labour 2003). The 1990s therefore exposed the weakness of the specialization model. Complete specialization between the sexes entails considerable risks:

An inherent problem is that the temporary or permanent loss of one specialist in a family can mean that functions vital to the well-being of the complementary specialist and children are not being performed. Husbands/fathers can die or become ill or disabled; they can lose their jobs and have difficulty finding another one ... The result is that the family is left without its major source of income. Except for employment-related shifts, there are similar problems involving the wife-mother specialist. In that case, there could be no one to take care of the children or the home.

(Oppenheimer 1997: 447)

Women's decreasing dependency on their husbands may be linked to the rise in divorce rates in the 1990s, suggesting that the patterns of divorce may have a transitory component. Employment security and automatic wage growth could no longer be taken for granted; the future of the family's well-being was no longer predictable or stable. The prospect of economic uncertainty "pushed" many housewives into the labor force, which, in turn, lowered their economic dependency, and gave them greater opportunity to walk away from marriage. It is thus conceivable that the 
women will be "pulled out" of the labor force if the economy recovers and employment stability becomes the norm once again.

\section{Role of the welfare state}

The social structure of modern society differs markedly from that of primitive tribes and villages in that traditional family roles are being replaced by welfare services (Coleman 1990). This transition can be seen as a natural consequence of economic development, where interpersonal relations are replaced with institutions more complementary to a market-based economy (Stiglitz 2000). Caring for the children or the aged, for example, has long been the primary function of families, but is now increasingly subsidized by the state, especially in the so-called welfare state economies of Scandinavia. For example, in Sweden, generous maternal (and paternal) leave benefits and subsidized childcare programs allow women to balance their work and family obligations. These benefits lead to a higher proportion of working mothers in Sweden, as illustrated in Table 9.1 and Figure 9.2. Further, women who exit marriages in Sweden are not forced into poverty because the welfare state provides a wide safety net for single mothers that includes income transfers for children, housing subsidies, and reduced costs for daycare and other social services (Hobson 1990).

In contrast, the male breadwinner model that characterized postwar economic development in Japan assumed that the welfare of the families was a private affair, and the responsibility of the wives. The lack of welfare services in Japan discourages women from seeking full-time jobs, increases wives' dependence on their husbands and further deters women from divorce. Less support for the welfare of single mothers in particular may explain the lower incidence of one-parent families in Japan relative to the countries of Scandinavia (Table 9.1).

The strength of intergenerational ties and support is one example where the extended family substitutes for the welfare state in Japan. Coresidence with parents or in-laws allows wives to share the burden of household responsibilities with the extended family. Sasaki (2002) finds that co-residence increases the probability of labor-force participation among married women with young children (under six years).

\section{Demographic change}

One of the noticeable patterns in the postwar period is the increasing rate of divorce among older couples. The proportion of divorce cases among couples married for over 20 years increased from 3.1 percent in 1947 to 16 percent in 1996 (Ministry of Health and Welfare statistics, cited in Iwai 1999). In 1970, the average duration of marriage at the time of divorce was 6.8 years, but by the mid-1990s it had reached ten years, indicating that many more couples who had been married for a decade or more were 


\section{Hiroshi Ono}

starting to divorce (Curtin 2002). Advances in the economic position of women and the decline in the stigma of divorce, as previously discussed, are some of the factors behind this trend.

Improvement in life expectancy may be another source of late-life divorce. The average Japanese woman can now expect to live until the age of 85 . If the husband retires at the age of 60 , this means that the typical couple can expect to live together for over 20 years after retirement. Since men have devoted most of their lives to work, many Japanese couples are not accustomed to spending so much time with their spouse in close proximity. If the couple does not get on well, or one has less tolerance than the other, then increases in longevity increase the possibility of a late-life divorce (Curtin 2002). Iwao (1993), for example, documented one case of a "retirement divorce" where the wife left her husband on the day of his retirement. Although such extreme cases tend to be overblown by the media, there is now growing anecdotal evidence that retirement divorce has become more common than it was in the past. ${ }^{13}$

The increasing divorce rate is also associated with declining fertility, although the causation is not clear. The decline in the birthrate means that the couple is, at any given age, more likely to have fewer children, and less likely to have any children at all. Children constitute a prime example of investment in "marital-specific" capital (Becker 1993). Because one of the main costs of divorce is the cost imposed on the children, having fewer children or no children at all lowers the cost of divorce. Indeed, divorce is less likely in the presence of children, especially young children (Ono 1998; Waite and Lillard 1991), although this effect is somewhat endogenous: "Expectations about divorce are partly self-fulfilling because a higher expected probability of divorce reduces investments in (marital) specific capital and thereby raises the actual probability" (Becker 1993: 329). In other words, if women perceive that the marriage is more likely to end in divorce, then they are also less likely to have children.

\section{Summary and conclusions}

The divorce rate in Japan is rising. There is no single cause for the weakening of the institution of marriage in Japan. Rather, the changing pattern of marriage and divorce is the outcome of the dynamic interactions between economic development and demographic change at the macrolevel, and changes in social norms and attitudes that govern the behavior of individuals at the micro-level.

One of the lessons from the United States and Europe concerns the trade-off between gender equality and marital stability. The drive toward equal status between the sexes narrows the dependency between the spouses, and offsets the costs and benefits of marriage. Lower dependency allows greater voice, and lowers the cost of exiting a marriage. The diversity of family forms such as civil unions and cohabitation allows couples to 
choose alternatives to marriage, which in turn weakens the institution of marriage itself. The divorce rate in Japan is low compared to Western societies because dependency between the spouses is greater, alternatives to marriage are fewer, and the legacy of the traditional gender division of labor continues to influence the actions and attitudes of men and women.

Achieving gender equality is now a key policy issue in Japan. The Equal Employment Opportunity Law was introduced in 1986 and revised in 1999; more recently, initiatives have been introduced to eliminate gender bias in the tax and benefit system, and to improve the welfare of single-parent families. These initiatives are all carefully modeled from their predecessors in the United States and Europe. In other words, gender equality in Japan will be achieved by emulating aspects of the U.S. and European models.

There are, however, counteracting pressures to preserve the institution of marriage and family. A notable example of this concerns the debate concerning whether spouses should be able to keep their family names after marriage. Originally proposed in 1991, the issue has not yet been resolved and the debate is ongoing (Iwai 1999). The extent to which Japan internalizes Western values while preserving traditional values will have a profound influence on the future of marriage and family formation in Japan.

\section{Notes}

1 This point is explicitly made in Ishizaka (1973) who explains that an employment relationship must take into consideration the well-being of the family; workers must be compensated sufficiently to sustain a reasonable quality of life, not only for themselves but also for their families.

2 The current discussion about the New Life Movement draws significantly from Gordon $(1997,1998)$.

3 See Ono and Rebick (2003) for a review of the literature concerning the impact of tax and benefit schemes on women's labor-force participation in Japan.

4 Another common statistic used in international comparisons is the divorce rate per 1,000 persons. However, while alternative forms of marriage such as cohabitation and civil unions may be widespread in other countries, marriage and family formation in Japan is still relatively homogenous. The high proportion of cohabiting couples in other countries, for example, does not appear in the divorce statistics, in the event of a break-up, when the figures are reported as "divorce per 1,000 persons." Hence the divorce rate per 100 married couples is a more appropriate measure when accounting for the diversity of marriage and family formation.

5 Results are based on a random sample of women aged 20 years or older in the six countries.

6 Survey results from the Prime Minister's Office (cited in Iwai 2002) indicate that the proportion who agreed to the statement, "It's better to seek divorce if unsatisfied with one's spouse," increased from 21 to 53 percent among men, and from 21 to 55 percent among women between 1972 and 1997. See also Retherford et al. (2001) for an international comparison of these survey results.

7 Japan is now one of the latest-marrying populations in the world. Between 1975 


\section{Hiroshi Ono}

and 1995, the mean age at marriage increased from 24.5 to 27.7 years for women and 27.6 to 30.7 years for men; during the same period, the proportion who will never marry increased from 5 to 15 percent for women and from 6 to 22 percent for men (Retherford et al. 2001).

8 The social sanctions for divorce may not be symmetrical for men and women. For example, Iwao (1993) explained that divorced women in the prewar period were viewed as "damaged goods" because women were expected to be virgins at marriage.

9 Similarly, Bryant (2001) describes one woman who waited for eight years for her two sons to start their careers before she initiated the divorce.

10 Becker (1993) explained that the growth in the earnings of women has been a major cause (and also a result) of the growth in divorce in the U.S.A.

11 See, for example, statistics from the International Labour Organization (ILO) and the United Nations Development Programme (UNDP).

12 The empirical evidence on the decline of lifetime employment is mixed, and it is hasty to assume that the institution of lifetime employment is defunct. See, for example, Kato (2001) and Rebick (2001), who argue that there were little signs of change in the Japanese employment system during the 1990s. See also the chapter by Moriguchi and Ono in this volume for discussion concerning the future of lifetime employment.

13 See, for example, Sakurai, Joji, "Divorce rate for Japan's elderly couples is growing," Associated Press, March 19, 2000, and "Divorces hit all-time high in Japan, as more middle-aged couples split," Canadian Press, September 17, 2003.

\section{References}

Becker, Gary S. (1993) A Treatise on the Family. Cambridge, MA: Harvard University Press.

Brinton, Mary C. (1992) "Christmas Cakes and Wedding Cakes: The Social Organization of Japanese Women's Life Course," in Takie Sugiyama Lebra (ed.), Japanese Social Organization. Honolulu: University of Hawaii Press, pp. 79-107.

— (1993) Women and the Economic Miracle: Gender and Work in Postwar Japan. Berkeley: University of California Press.

Bryant, Taimie L. (2001) "Marital Dissolution in Japan: Legal Obstacles and Their Impact," in Curtis J. Milhaupt, J. Mark Ramseyer and Michael K. Young (eds) Japanese Law in Context: Readings in Society, the Economy, and Politics, Cambridge: Harvard University Press, pp. 372-7.

Bumpass, Larry L. and Minja Kim Choe (2004) “Attitudes Relating to Marriage and Family Life" in Noriko O. Tsuya and Larry L. (eds) Marriage, Work and Family Life in Comparative Perspective: Japan, South Korea and the United States. Bumpass. Honolulu: University of Hawai'i Press, pp. 19-38.

Coleman, James S. (1990) Foundations of Social Theory. Cambridge: Belknap Press of Harvard University Press.

Curtin, J. Sean. (2002) "Living Longer, Divorcing Later: The Japanese Silver Divorce Phenomenon." Glocom Platform from Japan, August 5, 2002.

England, Paula and Barbara Stanek Kilbourne (1990) "Markets, Marriages, and Other Mates: The Problem of Power," in Roger Friedland and A. F. Robertson 
(eds) Beyond the Marketplace: Rethinking Economy and Society. New York: Aldine de Gruyter, pp. 163-88.

Gordon, Andrew (1997) "Managing the Japanese Household: The New Life Movement in Postwar Japan.” Social Politics 4: pp. 245-83.

_ . (1998) The Wages of Affluence: Labor and Management in Postwar Japan. Cambridge: Harvard University Press.

Higuchi, Yoshio (1995) "Sengyo shufu hogo seisaku no keizai-teki kiketsu" (The Economic Consequences of Policies to Protect Full-time Housewives), in Tatsuo Hatta and Naohiro Yashiro (eds) Jakusha hogo seisaku no keizai bunseki. Tokyo: Nihon Keizai Shimbunsha, pp. 185-219.

Hobson, Barbara (1990) "No Exit, No Voice: Women's Economic Dependency and the Welfare State." Acta Sociologica 33: pp. 235-50.

Ishizaka, Iwao (1973) "Shushin Koyo, nenko chingin to shokunokyu" (Lifetime employment, seniority wages and job performance pay), in Ichiro Nakayama and Miyohei Shinohara (eds) Nihon Keizai Daijiten. Tokyo: Kodansha, pp. 403-4.

Iwai, Noriko (1999) "Divorce in Japan: Historical Changes and Current Issues," in Robin R. Miller and Sandra Lee Browning (eds) With This Ring: Divorce, Intimacy, and Cohabitation from a Multicultural Perspective. Stamford: JAI Press, pp. 53-77.

— (2002). "Shiawase de nakereba rikon shita houga iika?" (Is it better to divorce if one is not happy?), in Noriko Iwai and Hiroki Sato (eds) Nihonjin no Sugata (Japanese values and behavioral patterns seen in the Japanese General Social Survey). Tokyo: Yuhikaku, pp. 65-71.

Iwao, Sumiko. (1993) The Japanese Woman: Traditional Image and Changing Reality. New York: Free Press.

Japan Institute of Labour (2003) “The M-shaped Distribution of Working Women Becoming Smoother." JIL Labor Flash. Vol. 41.

Kato, Takao (2001) "The End of Lifetime Employment in Japan?: Evidence from National Surveys and Field Research.” Journal of the Japanese and International Economies 15: pp. 489-514.

Moriguchi, Chiaki and Hiroshi Ono (2006) "Japanese Lifetime Employment: Response to Crisis in Historical Perspective," in Magnus Blomström and Sumner La Croix (eds) Institutional Change in Japan. Abingdon, Oxon: Routledge.

National Institute of Population and Social Security Research (1999) Eleventh Japanese National Fertility Survey, Volume 2. Tokyo: National Institute of Population and Social Security Research.

Ochiai, Emiko (1997) The Japanese Family System in Transition: a Sociological Analysis of Family Change in Postwar Japan. Tokyo: LTCB International Library Foundation.

Ono, Hiromi (1998) "Husbands' and Wives' Resources and Marital Dissolution." Journal of Marriage and the Family 60: pp. 674-89.

Ono, Hiroshi and Marcus E. Rebick (2003) "Constraints on the Level and Efficient Use of Labor" in Magnus Blomström, Jennifer Corbett, Fumio Hayashi and Anil Kashyap (eds) Structural Impediments to Japan's Economic Growth. Chicago: NBER and University of Chicago Press, pp. 225-57.

Oppenheimer, Valerie Kincade (1997) "Women's Employment and the Gain to Marriage: The Specialization and Trading Model." Annual Review of Sociology 23: pp. 431-53. 


\section{Hiroshi Ono}

Organization for Economic Co-operation and Development (2003) Society at a Glance. OECD Paris.

Rebick, Marcus E. (2001). “Japanese Labor Markets: Can We Expect Significant Change?" in Magnus Blomström, Byron Gangnes and Sumner La Croix (eds) Japan's New Economy: Continuity and Change in the Twenty-First Century. Oxford: Oxford University Press, pp. 120-41.

Retherford, Robert D., Naohiro Ogawa and Rikiya Matsukura (2001) "Late Marriage and Less Marriage in Japan." Population and Development Review 27: pp. 65-102.

Rohlen, Thomas P. (1974) For Harmony and Strength: Japanese White-Collar Organization in Anthropological Perspective. Berkeley: University of California Press.

Sasaki, Masaru (2002) "The Causal Effect of Family Structure on Labor Force Participation among Japanese Married Women.” Journal of Human Resources 37: pp. 429-40.

Stiglitz, Joseph E. (2000) "Formal and Informal Institutions," in Partha Dasgupta and Ismail Serageldin (eds.) Social Capital: A Multifaceted Perspective. Washington, D.C.: World Bank, pp. 59-68.

Tokyo Metropolitan Government (1994) International Comparative Survey Concerning Issues Confronting Women. Tokyo: Tokyo Metropolitan Government.

Tsuya, Noriko O., Karen Oppenheim Mason, and Larry L. Bumpass (2004) "Views of Marriage among Never-Married Young Adults." In Noriko O. Tsuya and Larry L. Bumpass (eds) Marriage, Work and Family Life in Comparative Perspective: Japan, South Korea and the United States. Honolulu: University of Hawai'i Press, pp. 39-53.

United Nations (2000) World's Women. New York: United Nations.

Uno, Kathleen S. (1993) "The Death of 'Good Wife, Wise Mother'?" in Andrew Gordon. Berkeley (ed.) Postwar Japan as History. University of California Press, pp. 293-322.

Vogel, Ezra F. (1991) Japan's New Middle Class: The Salaryman and His Family in a Tokyo Suburb. Berkeley: University of California Press.

Waite, Linda J. and Lee A. Lillard (1991) "Children and Marital Disruption." American Journal of Sociology 96: pp. 930-53.

Whiteford, Peter and Jonathan Bradshaw (1994) "Benefits and Incentives for Lone Parents: A Comparative Analysis." International Social Security Review 47: pp. 69-89.

Yamashita, Katsutoshi (1986) "Divorce, Japanese Style." Japan Quarterly 33: pp. 416-20. 


\section{Index}

Italic page numbers indicate figures not included in the text page range.

accounting reforms 101

Acemoglu, Daron 19, 36

acquisitions: hostile 103, 106, 108

age restrictions: employment 168-9

aging population problem 169

amakudari (descent from heaven):

communication perspective 205-6,

209, 212; compensation perspective

207-9, 212; decline 202-3; definition

202; human resource perspective

204-5, 209; monitoring perspective

206-7, 208-9, 212; pattern of

appointment 213-17; regulation of 202

amendments: Commercial Code 98-101

Anglo-American model 66, 75, 76, 80

Aoki, Masahiko 17, 22-3

APEC (Asia Pacific Economic Cooperation) 37

ASEAN (Association of South East Asian Nations) 36-7

banking system $37,58-60,133$

Bank of Japan (BOJ) 58-9, 122, 131, 136-9, 141, 203-4, 209-17

bankruptcy $112,145,211$

banks 58-60, 80, 83, 133, 203-4, 209-17; see also regional banks

Becker, Gary 21

Befu, Harumi 73

behavioral change 111-14

belief systems 132-3

board reforms 101, 105-6, 107, 112

BOJ see Bank of Japan

bonsai liberalization 129-30

bubble economy 165-7

bureaucracy: Meiji period 49-50 bureaucrats $27-8$

business institutions: Meiji period 60-3 buybacks: share 106

cabinet system 50

Calder, Kent 205

capital: provision of 60,62

capital-asset requirements 133

capitalism 76, 77

Cargill, Thomas F. 211

caste system 49

catch-up model: of political economy 77-8

central bank policy $136-8$

chaebols 73, 82, 83-6

China 37

Civil Code (1898) 49

Civil Rehabilitation Act (2000) 100, 112

Coase, Ronald 17

cohabitation 226, 227, 233

command-and-control style regulations 25

Commercial Code 109-10

Commercial Code amendments 98-101, 110

commercial sector $50-1$

committee system 107

compensation 35-6

competition: among organizations 2,18 , 28

complementarity of institutions 22-3,

$$
\text { 111-12 }
$$

constitutional government 56

constrained efficiency analysis $21,26-7$

corporate governance: behavioral change 111-14; board reforms 104-5, 107, 112; employment practices 


\section{Index}

corporate governance continued 108-9; hostile takeovers 103-4, 107-8; institutional investors 107; legal amendments 97-101, 109-11; mergers and acquisitions 104-5; norm shifts 104-5; shareholder activism 102-4, 107

corporate law 97-101

corporate management 112-13

corporate welfarism 155-6

country-specific factors: resisting reform 127-36

CPI (Consumer Price Index) 122

crises, financial 33

culture systems 132-3

currency 59

Curtis, Gerald 27

Daiwa Bank litigation 103

David, Paul 19, 46

decentralization 37-8

deflation 33-4, 120, 138-41

demographic changes 146, 169, 231-2

deposit insurance 122, 144-5

depressions, economic 32

deregulation initiatives $30,72,83-4,211$

derivative suits 102-4

developmentalism 76

developmental state $25-7$

disintermediation 131, 142, 143

divestitures 100

divorce: economic dependency of women 228-31; older couples 231-2; rate $221,224-5,226-8,231$; social norms 224-6, 232; stigma of 226-8

Douglas, Mary 46

economic depressions 32; see also Great Depression

economic growth: (1953-73) 21-2,

$$
\text { 25-7 }
$$

economic models $33-4$

economic policies 33

economic reforms: governmental 30-3

Economic Strategy Council 194

education 51

electoral system 27

emergency powers 23

employment adjustments 161, 167, 168

employment policy report: Rengo 189-91

employment practices 63-4, 108-9

employment relations 63-4

Employment Stability Project 164-5
England, Paula 228

enterprise unions 161,166

entrepreneurship 61-2

equality: gender 229, 232-3

evaluation: relative performance $37-8$

exchange-supporting institutional

analysis $20-1$

Factory Act (1910) 63

family businesses 61, 62-3, 73

family system 49

farmers 36

FILP (Fiscal Investment Loan

Program) 26, 30-1, 122, 133-4, 142-3

financial crises 33

financial institutions: core elements (1950s) 128-9

financial reform process 124-7

Financial Services Agency (formerly

Financial Supervisory Agency) 122

Financial Supervisory Agency (later

Financial Services Agency) 211

financial system: Meiji period 58-60

fiscal policies 33-4

fiscal stimulus packages 122

flexibility enhancing amendments 98-100

free trade agreements (FTAs) 36-7

Fruin, W. Mark 46

Fukui, Toshihiko 141

GDP 120, 121

gender issues 222-4, 228-30, 232-3

Gerschenkron, Alexander 55

Gordon, Andrew 223, 233

governmental economic reforms 30-3

government officials: retirement system 208

Great Depression 157-9

Greif, Avner 17, 29

Gyohten, Toyoo 78

Hartcher, Peter 205

Hayami, Masaru 205

Hayami, Yujiro 78

hereditary caste system 49

Higgs, Robert 23

Hobson, Barbara 228, 231

holding companies 99

Horiuchi, Akiyoshi 207

Hoshi, Takeo 37

hostile takeovers 103, 106, 108

HRM practices: lifetime employment 153-5 


\section{Hurwicz, Leon 17}

ideologies 75

incremental change 18, 29

industrial policies 25-7; Korea 82-3

inequality: gender 229, 232-3

inflation 136-7

infrastructure provision 26, 51

insolvency 112

institutional change: definition of 45-6; determinants of 28-30; history of

31-2; incremental 18, 29

institutional investors 107

"institutional learning" 46-7

institutions: complementarity of 22-3; definition of 17; and organizations 28 , $45-6$; theory of $17-21$

interest groups $24-5,27,35,71,75$, $83-6,112$

interest rates 122

investors: institutional 107

Iwao, Sumiko 227-8, 232, 234

Japan Federation of Employers' Associations (Nikkeiren) 191

Japan-Mexico Free Trade Agreement 36-7

Japan Post (formerly Postal Savings System, PSS) 123, 142-4; see also Postal Savings System (PSS)

Japan Productivity Centre (JPC) 181 job mobility 168-9

Johnson, Chalmers A. 205-6

Kashyap, Anil 37

Kehoe, Timothy 32

Keidranren 180, 194

keyboard layouts: (path dependence) 19

Kilbourne, Barbara Stanek 228

Kim Dae-jung 86

Kim Jae Ik 81

Kim, Pyung Joo 80-1

Koizumi, Junichiro 35, 120, 142, 146, 147

Korea 37, 72, 73, 80-7, 127, 134-5

Krugman, Paul 145

labor force participation: women 222, 228-31

labor market: Meiji period 63-4

labor movement: (1910s) 156; (1945-75)

159, 178-83; (1975-90) 183-9; (1991-2003) 189-98; wage restraint policy 164
La Croix, Sumner 71

laws: corporate 97-101; Large-Scale Retail Store Law 30; National Civil Service Law 202

Legislative Reform Council 110

Libecap, Gary 29

Liberal Democratic Party (LDP) 27-8, $36,135,187-8$

lifetime employment: bubble economy 165-7; change in 108-9, 152-3; corporate welfarism 155-6; and divorce rate 230; future of 167-70; gender implications 222; Great Depression 157-9; "high-growth period" 162-3; HRM practices 153-5; oil crisis 164-5; origins 155-6; postwar era 159-62; Rengo report 190

Lincoln, Edward 72, 132

Lin, Justin Yifu 87

liquidity trap 140

manufacturing sector 50-1

marketization 196

market pressures $107-8$

market principles 128-9

marriage 221, 224-7, 228-30, 232

Meiji period 45

Meiji transformation: business institutions 60-3; evaluation of 52-5; financial system 58-60; implications for modern Japan 65-7; labour market 63-4; the Meiji government 55-8; overview 49-52

merchant banks 83

merchant guilds 29-30

merger procedures 99

mergers and acquisitions (M\&A): friendly 104-5; hostile 103, 106

military strength 50

Ministry of Economy (METI) 110-11

Ministry of Finance (MOF) 203-4, 209-17

Ministry of International Trade and Industry (MITI) 110

models: economic 33-4 monetary policies $33-4$

monitoring enhancing amendments 98 , 100-1

moral hazard 130, 131

Morishma, Michio 77

Murakami, Yasusuke 76, 77

National Civil Service Law 202 


\section{Index}

national identity 73-4

National Personnel Authority (NPA) 202

neoliberalism 75

networks, policy 76-7

New Institutional Economics 17-21

New Life Movement 223, 233

New Zealand 32, 33, 72

Nikkeiren (Japan Federation of Employers' Associations) 191

Nippon Keidanren 197-8

Nissan 193

Noguchi, Yukio 24

nonperforming loans 120-1, 137, 142

norm shifts 106-7

North, Douglass 17-18, 19-20, 28, 29, 87

Nugent, Jeffrey B. 87

oil crisis $164-5$

Okazaki, Tetsuji 24

Okimoto, Daniel I. 76-7

Okuno-Fujiwara, Masahiro 24

oligarchic control 50

Olson, Mancur 21, 24-5, 48, 112

on-the-job training 162-3

Oppenheimer, Valerie Kincaird 228, 230

opposition: to reform $1,16,35-6,71,75$

"organisational learning" 46-7

organizations: financial 26-7; and institutions 18, 28, 45-6

Pacific Rim countries 36-7

Park Chung Hee 80

path dependence 2,18, 19-21, 23-4, 29

policies: economic 33

policy errors $136-8$

political economy: Japanese 75-9

Postal Savings Bank 26

Postal Savings System (PSS) 120, 123, 133-4, 142-3

Prescott, Edward 32

privatization 30,187

Prompt Corrective Action 122

protests: Meiji period 53, 55-6

public choice analysis 21,26

public-private policy networks 76-7

QWERTY keyboards: (path dependence) 19

Ramseyer, Mark 27 ratchet effect 23-4 reemployment, bureaucratic see amakudari (descent from heaven)

reforms: governmental 30-3; Meiji see Meiji transformation; in rich countries 32-3, 72

regional banks: and amakudari 203-4, 209-17

regulations: command-and-control style 25

Rengo (Japan Trade Union

Confederation) 9, 178, 180, 189-98

repeated-game model 29-30

repurchases: share 106, 109

retention rates 152

"retirement divorce" 232

retirement system: government officials 208

rich countries 32-3, 72

Rincho (Second Extraordinary

Commission on Administrative

Reform) 187, 189

Robinson, James 36

Rohlen, Thomas R. 77

Rosenbluth, Frances 27

Saigō Takamori 53, 55-6

Sato, Kazuo 71

SCAP (Supreme Commander for the Allied Powers) 72, 159

Schotter, Andrew 17

separation rates 153

service overtime 195, 196

share buybacks 106, 109

share-for-share exchanges 99

shareholder activism 102-4

shareholder derivative suits 100-1

Shareholder (Kabunushi) Ombudsman 104

shareholder wealth maximization 97

Shimizu, Katsutoshi 207

short-run pressures 47-8

Shunto (Spring Struggle) 182-6, 192-3

Singapore-Japan Free Trade

Agreement 36

single parents 231,233

social capital see networks, policy

social contracts $179-80$

social credibility: bureaucratic

management 202, 211

social welfare policies 196

South Korea see Korea

sovereignty 50

specialization: of the sexes 222-3, 228-9, 230 
spin-offs 100

split-offs 100

Spring Offensive 163

statutory auditory system 101

Stigler, George 21

stock options 99, 110

Supreme Commander for the Allied

Powers (SCAP) 72, 159

Sweden 33, 225, 226, 231

Switzerland 32, 72

takeovers: hostile 103,106, 108

technological standards 19

"telephone book": labor movement list 188

temporary workers 158

theory of institutions 17-21

"Toyota Effect" 111

trade agreements $36-7$

trade unions 158-60, 166; see also labor movement

transaction costs 20-1

Tsuya, Noriko O. 226

unemployment rate 168

unions 158-60, 161, 166

United States: financial liberalization

126-7; postal saving system 143;

pressure from 129
Uno, Kathleen S. 223

venture capital 110

voluntary retirement 157-9

wage bargaining 182-6, 192-3

wartime changes $23-4$

Washington consensus 81

Weingast, Barry 29

Weinstein, David 25-6

welfare programs 160

welfare society 186,195

welfare state 231

Western influence 51, 52, 56-7

Westernisation 51, 52, 72, 79

Westney, Eleanor 47

Williamson, Oliver 20

Wolferen, Karel van 206

women: economic dependency 228-31; education 223, 228, 230; employment 222-3, 228-31

Yamashita, Katsutoshi 227

Yamazawa, Ippei 71

Yanagisawa, Hakuo 205

the yen 59, 129, 136-7

zaibatsu 24, 60, 62 


